\title{
Die lewende stem \\ van die evangelie
}

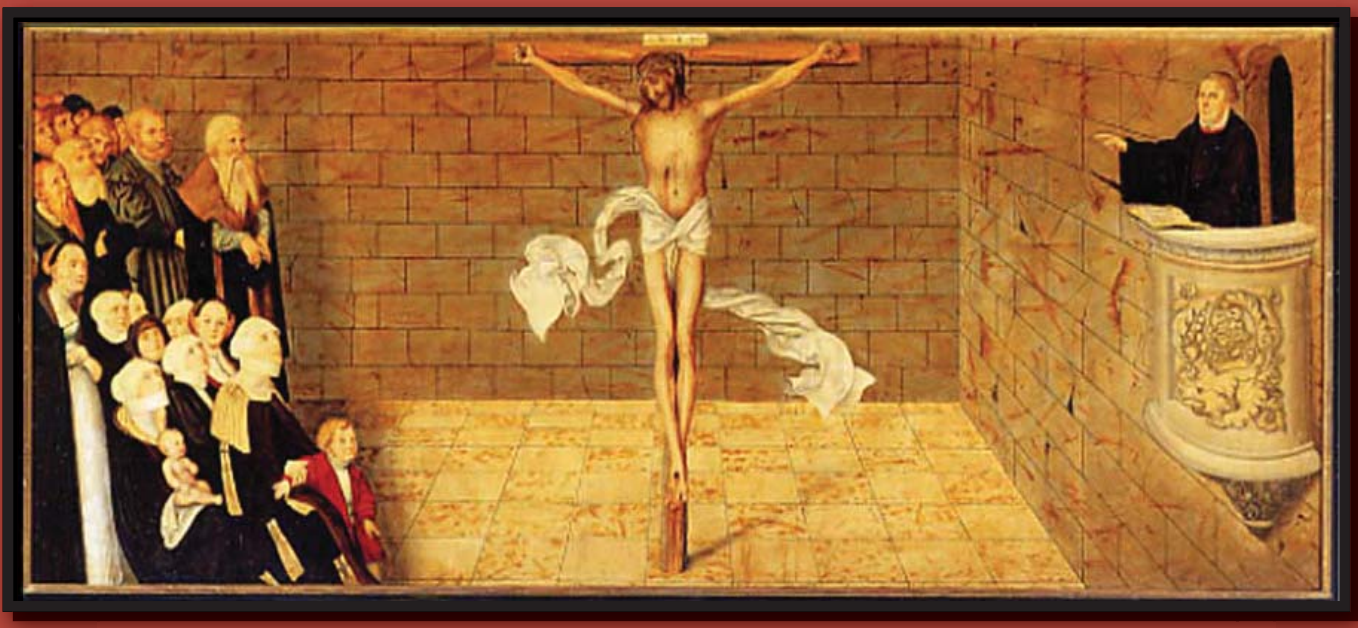

Nuut gedink oor die basiese beginsels van prediking

JOHAN CILLIERS 
e 


\title{
Die lewende stem van die evangelie
}

Nuut gedink oor die basiese beginsels van prediking

\author{
Johan Cilliers
}


SUN PRESS is ' $n$ afdeling van AFRICAN SUN MeDIA, die Universiteit van Stellenbosch se uitgewery wat akademiese, naslaan- en professionele werke in elektroniese en gedrukte vorm publiseer. Hierdie publikasie kan afgelaai of regstreeks bestel word by www.sun-e-shop.ac.za.

Die lewende stem van die evangelie is 'n grondige herskrywing en uitbreiding van drie vorige boeke deur Johan Cilliers, almal publikasies van Lux Verbi, Kaapstad: Die uitwissing van God op die kansel. Ontstellende bevindinge oor Suid-Afrikaanse prediking (1996), Die uitwysing van God op die kansel. Inspirerende perspektiewe op die prediking - om God te sien en ander te láát sien (1998) en Die genade van gehoorsaambeid. Hoe evangelies is die etiese preke wat ons in Suid-Afrika hoor? (2000).

\author{
Die lewende stem van die evangelie \\ Uitgegee deur SUN PRESS, 'n afdeling van \\ AFRICAN SUN MeDIA, \\ Victoriastraat, Stellenbosch 7600 \\ www.africansunmedia.co.za \\ Alle regte voorbehou \\ Kopiereg (C) 2004 J.H. Cilliers
}

Geen gedeelte van hierdie boek mag sonder die skriftelike verlof van die uitgewer gereproduseer of in enige vorm deur enige elektroniese, fotografiese of meganiese middel weergegee word nie, hetsy deur fotokopiëring, plaat-, band- of laserskyfopname, vermikrofilming, via die Internet of e-pos of enige ander stelsel van inligtingsbewaring of -ontsluiting.

Eerste uitgawe 2004

ISBN: 978-1-919980-07-2 | e-ISBN: 978-1-919980-32-4 | DOI: 10.18820/9781919980324

Die lied "Pepermunt" deur Stef Bos aangehaal met die vriendelike toestemming van die sanger.

Bandontwerp en tipografie deur Felini Studio

Geset in 11 op $12.5 \mathrm{pt} \mathrm{Janson}$

Gedruk en gebind deur US Drukkery,

Victoriastraat, Stellenbosch, 7600 
"I did not invent this Word of God and this office. It is God's Word, God's work, His office. There we two (i.e. God and I) are one in the cause... It is our confidence, no matter bow much the world may boast, that God has qualified us to be ministers, and, secondly, that it is not only pleasing to the beart of God, but also that we shall not preach in vain and this ministry will lift to beaven some few who receive the Word."

"The office of preaching is an arduous task... I have often said that, if I could come down with a good conscience, I would rather be stretched upon a wheel and carry stones than preach one sermon. For anyone in this office will always be plagued; and therefore I have often said that the damned devil and not a good man should be a preacher. But we're stuck with it now... If I had known I would not have let myself be drawn into it with twenty-four horses." (Martin Luther) 


\section{Inhoud}

\section{Voorwoord 1}

Hoofstuk 1: Het die prediking (nog) 'n toekoms? 3

1.1

1.2

1.2.1

1.2 .2

1.3

1.3 .1

1.4

1.5

1.6

1.7

1.7.1

1.7.2
Heilige dwaasheid? 3

Kritiek vanuit die sosiale wetenskappe 6

'n Definisie van postmodernisme? 7

'n Beoordeling van postmodernisme? 8

Kritiek vanuit die kommunikasie wetenskappe 9

'n Kultuur van beelde? 9

Kritiek vanuit die teologiese wetenskappe 14

Kritiek uit die kerkbanke 15

Pastorale faktore 18

Prediking: Die hart en die hoop van die kerk 19

Prediking: Die hart van die kerk 19

Prediking: 'n Hoopvolle handeling 19

Hoofstuk 2: Die geheim van die prediking:

Een-stemmigheid op die kansel 22

2.1

2.2

'n Besoek aan 'n kunsgalery... 22

2.3

2.3.1

Woorde, woorde, woorde... 24

2.3 .2

'n Definisie van die prediking: een-stemmigheid op die kansel 25

2.3.3 Die stem as dinamiese fenomeen 28

2.4 Prediking as spel 33

2.4.1 Buitelyne van die speelveld 34

Hoofstuk 3: Die lewende stem van die evangelie:

Wanneer die teenwoordige God praat 38

3.1 Inleiding: Waarom gaan ons kerk toe? 39

3.2

3.2 .1

3.2 .2

3.2 .3

3.3

God se teenwoordigheid bring ons in beweging 41

Van familiariteit na Godsvrees 41

Van formalisme na vryheid 42

Van verbruikersmentaliteit na verwagting 43

3.4

Eredienste is spannend! 45

3.4.1 Die "eintlike benoudheid van die bedienaar van die Woord" 45 
3.4.2 Om te preek, is om te sê Wie was, is, en sal wees 46

3.4.3 Om te preek, is om jou skoene uit te trek 47

3.4.4 Om te preek, is om jou hande op te hef 48

3.4.5 Om te preek, is om te gryp na die gordyn 49

3.4.6 Om te preek, is om die Woord te vertrou 51

3.5 As God praat, hoor ons die evangelie van verlossing 51

3.5.1 Die kenmerke van die prediking van verlossing 53

3.5.1.1 Die crux van verlossingsprediking: niks anders as Christus nie 53

3.5.1.2 Die prediking van verlossing is 'n woord oor God... 55

3.5.1.3 … en 'n woord ván God 57

3.5.1.4 Die prediking van verlossing is die voort- en verder vertelling van 'n verhaal... 59

3.5.1.5 $\quad \ldots$ uit die mond van 'n méns... 63

3.5.1.6 ... én die Gees 63

3.6

3.6 .1

Die uitwysing van God op die kansel 65

3.6 .2

Kyk mooi - wie sien jy? 65

3.6 .3

Skrefiesoog/ oopoog deur die lewe... 66

3.6 .4

Kyk mooi - Wie sien jy? 68

3.6 .5

Uitwissing of uitwysing? 69

3.6 .6

3.7

En as ek nou nié sien nie? 71

En wéér 'n keer: Wié sien jy? 72

3.7 .1

Die uitwissing van God op die kansel 75

3.7 .2

'n Substituut vir God? 76

3.7 .3

Die basiese struktuur van wettisisme 79

3.7 .4

Moralisme en Godsbeeld 82

3.7 .5

Die antroponome subordinasie van God 83

'n Wettiese apokaliptiek 84

Preekvoorbeeld 1: Net fesus alleen (Markus 9:2-8) 87

Hoofstuk 4: Die lewende stem van die evangelie:

Wanneer die Bybelteks praat 91

4.1 Die multidimensionaliteit van die Skrif 91

4.1.1 ... open poorte tot nuwe wêrelde... 94

4.2 Die menslikheid van die Skrif 96

4.3 Die Goddelikheid van die Skrif 98

4.4 Die unieke boodskap van die Skrif 99

4.5 Implikasies vir die prediking 101

4.6 Die geheim van die prediking: om na die stem van die teks te luister 103

4.6.1 Dronk van troos... 103

4.6.2 'n “Ongepreekte Bybel?" 103

4.6.3 Hoe lees predikers die Bybel? 107

4.6.4 Die genre van die teks: bron vir kreatiewe prediking 109 
4.6.5 Bybelse tekste: vensters op die gesig van God 113

4.6.6 Bybelse tekste: Brûe wat wêrelde verbind 114

4.7

4.7.1 Historiese analogieë 118

4.7.2 Antropologiese analogieë 120

4.7.3 Kenmerkende retoriese tegnieke 122

4.7.3.1 Retoriese vrae 122

4.7.3.2 Retoriek van die superlatiewe 123

4.7.3.3 Verandering van die tydsvorm 124

4.7.4 Wanneer die (multidimensionele) teks gemuilband word... 125

4.7.4.1 Die wettiese vervalsing van die indikatief van die evangelie 126

4.7.4.2 Die wettiese vervalsing van die imperatief van die evangelie 127

4.7.5 'n Ander weg? 128

Preekvoorbeeld 2: Neem, lees! (7esaja 55: 1, 6-13) 131

Hoofstuk 5: Die lewende stem van die evangelie:

Wanneer die gemeente praat 136

5.1 Inleiding: in-stemming met die gemeente 136

5.2 Die gemeente: draer en beskermer van die waarheid 137

5.3 Twee paar oë sien beter as een... 141

5.3.1 Ek in my klein hoekie...? 142

5.3.2 $\quad \ldots$ en jy in joune? 143

5.3.3 Van oog tot oog... 146

$5.4 \quad$ Voorbeelde vir 'n preekgesprek en/ of Bybelstudie 147

5.4.1 Die "Heidelberg-metode" 148

5.4.2 Die "rondetafel-preekstoel" (McClure) 149

5.5 Teks en konteks 150

5.5.1 Kontoere van kontekstualisering 152

5.5.2 Drie hermeneutiese tradisies 155

5.6

5.7

5.8

5.9

5.9 .1

Kontoere van 'n spesifieke (Suid-Afrikaanse) konteks 157

Skuldbelydenis - 'n kreet om 'n nuwe Suid-Afrika 162

Die heiliging van die lewe 164

Preekvoorbeelde van 'n mislukte (moralistiese) visie op die gemeente 171

5.9.1.1 Ontkenning 172

5.9.1.2 Vervlakking 173

5.9.1.3 Opheffing 174

5.9.2 Die veredeling van die religieuse mens 175

5.9.3 Die beweging na die intra-psigiese 177 
5.9.4 Wettisisme en werklikheid 177

5.9.4.1 Die vergeesteliking van die evangelie 179

5.9.4.2 Valse teenstellinge 183

Preekvoorbeeld 3: Kan die kerk kniel? (Joh. 13: 1-17) 184

Hoofstuk 6: Die lewende stem van die evangelie:

Wanneer die prediker praat 187

6.1 Die geheim van die prediking: om mondig te word 188

6.2 Die ek in diens van die Ek 188

6.3 Die (verhoudings)integriteit van die prediker 191

6.4 Wie nie bid nie, kan nie preek nie 193

6.5 Die deugdelike bestaan van die prediker 195

6.6 Dis die Gees én ons... 197

6.7 Die gees maak ons kreatief... maar hóé? 199

6.7.1 'n Voëlvlug oor die geskiedenis van kreatiwiteit 200

6.7.2 Wat kan ons leer uit dié geskiedenis? 205

6.8 Wat is die kern van kreatiwiteit? 206

6.8.1 Kreatiwiteit is iets wat met jou "gebeur" 206

6.8.2 Kreatiwiteit is ook iets wat jy moet "leer" 207

6.8.2.1 Die vier fases van kreatiwiteit 208

6.9 Prediking as ver-beelding 214

6.9.1 Brein en beeld: 'n neurokognitiewe integrasie 215

6.9.2 Die Bybel as beelde-Boek 218

6.9.3 Die werking van beelde... 222

6.9.4 Prediking as ver-beelding: enkele riglyne 224

6.10 Preekvoorbeelde van die mislukte (moralistiese)

funksionering van predikers 225

6.10.1 'n Verskuiwing van die gesagsbasis 226

6.10.2 Hermeneutiek van die "ek" 228

6.10.3 Die vereensaming van die prediker 229

6.10.4 'n Glips van die tong? 229

6.10.5 'n Gebroke gesag... 230

Preekvoorbeeld 4: “Daar is die Lam van God...!” (Fob. 1:19-34) 232

Literatuur 236 


\section{Voorwoord}

Tussen sin en onsin;

Tussen teks en konteks;

Tussen prediker en hoorder;

juis daar lê die gebeure van die prediking. Hierdie tussen-in is 'n soort sinaps. Daardie senupunt tussen God en mens waar die vonk [die boodskap] deurkom as die Dwaasheid van God; Paulus noem dit Christus die Gekruisigde. Vanuit die gelaat van die lydende God word hierdie Kruiswoord die Waarheid. Wie inbeweeg saam met die skrywer in hierdie ruimte ontdek wysheid. Daarom dat Johan hierdie ruimte verwoord as die crux van die evangelie.

Hierdie boek waag binne hierdie ruimte. Dit gaan nie meer oor prediking as 'n vervelige monoloog of die oppervlakkige dialoog van gesels nie. Niks is binne hierdie ontmoetingsruimte van die prediking gewoon of vervelig nie. Die tussen-in van God dwing beide hoorder en prediker tot die pynlike ervaring van verstaan. Dit ontketen die spraak van die Gees wat mense saam met 'n skepping in barensnood laat "sug". Daardie diepe sluk na "suurstof" - die Bybel noem dit hoop, die periskoop vir die kerk in die 21 ste eeu.

Anderkant die ontnugtering van baie kerklidmate, anderkant die water op 'n eend se rug van agnostisisme, brand hierdie boek soos "peppermint crisp" in die geheue van die leser: die lewe word douvars nuut dáár waar God en mens mekaar omhels.

Ek is bly dat Johan ons terugbring na die kern van die kerk se taak: verkondiging en getuienis. Volgens hom is dit 'n "heilige spel" wat geloof laat oopbreek met 'n besondere kunsvorm: lag as die uitbundige vreugde nou dat die angel uit die dood is! Hierdie boek moenie "gekoop" en "verbruik" word nie; dit moet bestudeer word in die modus van verwagting sodat prediking weer vensters op God kan open. Maar dan moet ons die skoonheid van God "sien" in die aakligheid van die verwonde Christus: My God, my God waarom? Dan word ons "verbeelding" 'n belydenis: ek glo.

\section{Daniël Louw}

Dekaan Fakulteit Teologie, Stellenbosch

November 2003 


\section{Het die prediking (nog) 'n toekoms?}

In hierdie hoofstuk word inleidend geluister na 'n aantal kritiese stemme wat teenoor die prediking opklink, naamlik vanuit:

- Die sosiale wetenskappe, veral met betrekking tot die verskynsel van postmodernisme

- Die kommunikasiewetenskappe, veral in die lig van die kultuur van beelde

- Die teologiese wetenskappe, veral ten opsigte van huidige tendense

- Die kerkbanke, met gewone lidmate se ervarings, en

- Ander pastorale faktore, veral met die oog op die eise wat aan predikers gestel word

Die hoofstuk sluit af met 'n alternatiewe perspektief: prediking as die hart en hoop van die kerk

\subsection{Heilige dwaasheid?}

Uitgekrap teen 'n muur van wat eens die majestueuse paleis van Caesar in Rome was, tref 'n mens vandag nog, ná duisende jare, 'n provokatiewe prentjie aan, waarskynlik deur 'n kind geteken. 'n Prentjie van 'n esel wat soos ' $\mathrm{n}$ mens teen 'n kruis oopgespalk is. Iemand - 'n onbekende Christen - staan voor die kruis en aanbid die Esel. Dwarsoor die uitbeelding is in groot letters uitgekrap: Aleksamenos aanbid sy God.

God? 'n Esel? Aan 'n kruis? Hoe kan jy so 'n God aanbid? En ook nog oor Hom préék? Paulus was al van mening dat hierdie vreemde evangelie, waarvan die Kruis in die sentrum staan, vir sommige geheel en al absurd en belaglik sou wees, vir ander 'n struikelblok, 'n irritasie (1 Kor. 1:18-31). 


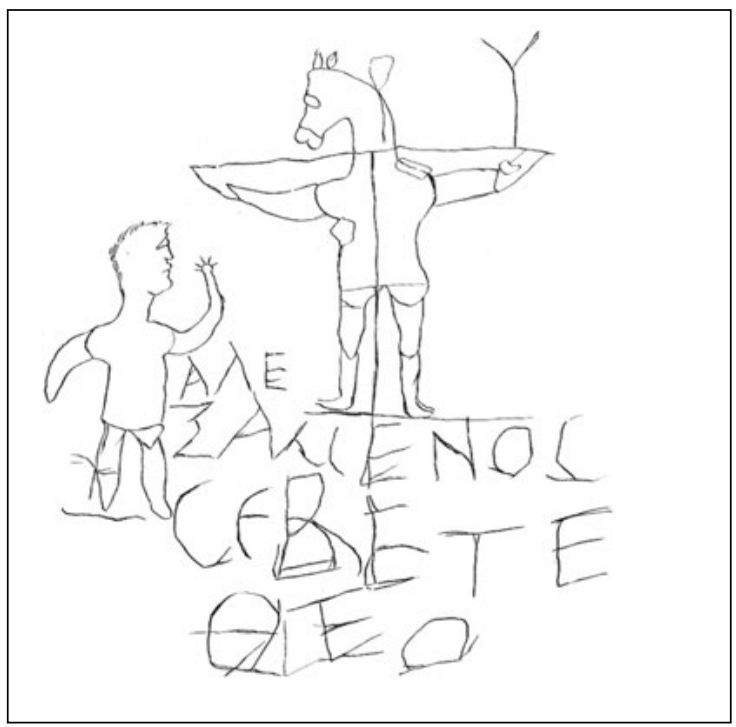

Onsin. Volledige en volslae dwaasheid. Dìs wat die prediking is. Want, stel jouself nou die volgende prentjie voor: hier staan 'n man of vrou voor 'n groep mense met verskillende geskiedenisse, behoeftes, persoonlikhede en verwagtings, en maak die mond oop met die veronderstelling of ten minste hoop dat sy of haar woorde op een of ander manier in God se woorde omskep gaan word, woorde wat moet heelmak en verlos, moet vertroos en rigting gee, en uiteindelik die diepste sin van ons bestaan moet uitspel. Stel jouself voor dat dié God wat die malende magte van die heelal anderkant die verste melkwegstelsel orkestreer, wat die grond en sentrum, die begin en uiteinde van die skepping en tyd is, wat die lewenskrag in die kleinste grashalm en die samebindende gom van die mees minuskule konsentrasie van atome êrens in 'n stofkorrel is, dat dié God deur die poort van 'n mensewoord, deur die gestotter en gestamel van 'n menslike stemband aan die Woord kom.

Maar, dis nie al nie: stel jouself voor dat dié God wat in die prediking aan die Woord moet kom, Homself giet in 'n mensevorm, dat Hy in die gedaante van 'n Babatjie met skoppende beentjies en kwylende mondjie binne die koördinate van tyd en ruimte gebore word. Dat Hy op 'n dag in die geskiedenis volgens wrede, antieke gebruik aan 'n houtpaal met spykers vasgekap word en aan die elemente oorgelaat word om 'n stadige dood te sterf. Dat Hy soos 'n Esel bespot word. Dat Hy drie dae daarna uit die dood uit opstaan, aan mense verskyn en demonstreer dat Hy leef, dat Hy op 'n wolk wegvaar na die hemel, en kort daarna sy Gees na sy volgelinge toe stuur om vir altyd by hulle te wees. Stel jouself voor dat hierdie vreemde versameling van feite en gebeure goeie nuus, oftewel evangelie genoem 
word, en dat jy in die prediking dit só moet verwoord dat dit op een of ander manier vir mense lig en lewe moet bring.

Dis genoeg om enige verstand te laat stilstaan. Jou sinies jou kop te laat skud. Dalk ongelowig te laat lag. Jou veral, as jy voorgee om 'n prediker te wees, oorweldig deur dié onmoontlikheid te laat terugsink op jou preekbankie agter op die preekstoel. Is dit nie gewoon gekheid om dít nog hier aan die begin van die derde millennium te glo nie? Onsin. Volledige en volslae dwaasheid...

Wel, baie mense dink so. Baie predikers het al uit hulle preekgeloof geabdikeer - al preek hulle nog elke Sondag. Hulle glo niks meer oor die prediking nie, of in elk geval weinig. Hulle verwag nie meer iets van die gebeure van die goddelike Woord nie. Hulle preek, maar eintlik praat hulle maar net. Hulle sê baie, en tog sê hulle nie iets nie. Hulle het professionele, godsdienstige redenaars geword, maar mense wat woorde uitspreek wat die geheimenis van God se evangelie verwoord en verwerklik? Nee wat, lank nie meer nie.

Hulle is nie alleen in hulle wantroue in die fenomeen wat ons prediking noem nie. A Niebergall verwys al in 1971 na "a deep scepsis, a consuming doubt about the task and method, the meaning and purpose of the sermon in general." (1971: 295-320)

En tog is hierdie skepsis en misnoë nie net beperk tot die afgelope aantal dekades of selfs eeu nie. Soos 'n pendulum swaai die preekervaring tussen moegheid en inspirasie, tussen boedel oorgee en nuwe verwagting. Blykbaar was die pendulum aan die minuskant, toe Anthony Trollope sy wanhoop aan die prediking in 1875 soos volg bekla het:

"There is, perhaps, no greater hardship at present inflicted on mankind in civilized and free countries, than the necessity of listening to sermons. Noone but a preaching clergyman has, in these realms, the power of compelling an audience to sit silent, and be tormented. No-one but a preaching clergyman can revel in platitudes, truisms and untruisms, and yet receive, as bis undisputed privilege, the same respectful demeanour as though words of impassioned eloquence, or persuasive logic, fell from his lips... A member of Parliament can be coughed down or counted out. Town councilors can be tabooed. But no-one can rid bimself of the preaching clergyman. He is the bore of the age... the nightmare that disturbs our Sunday's rest, the incubus that overloads our religion and makes God's service distasteful. We are not forced into church! No: but we desire more than that. We desire not to be forced to stay away. We desire, no, we are resolute, to enjoy the comfort of public worship; but we desire also that we may do so without an amount of tedium which ordinary buman nature cannot endure with patience; that we may be able to leave the house of God, without that anxious longing for 
escape, which is the common consequence of common sermons."(Barchester

Towers 1857, soos aangehaal deur John RW Stott 1982: 53-54)

Kritiek teen die prediking - hierdie heilige stuk dwaasheid wat elke Sondag gepleeg word - kán inderdaad opgestapel word. Ek vat van die belangrikste besware in dié debat kortliks saam:

\subsection{Kritiek vanuit die sosiale wetenskappe}

Dit is so dat daar geweldige skuiwe besig is om in samelewings in die algemeen, en ook in die Suid-Afrikaanse samelewing in die besonder, plaas te vind. In 1994 het ons 'n wonderwerk beleef met die transformasie van apartheid na 'n jong demokrasie. Sedertdien worstel die land met die nalatenskap van 'n verdeelde en traumatiese verlede, met aangeleenthede soos ekonomiese geregtigheid, armoede, die herverdeling van grond en in toenemende mate ook met die pandemie van Vigs. In sommige gebiede maak ons vooruitgang met reuse-spronge, vorder ons vinniger as wat ander lande in dekades en selfs eeue kon regkry. In ander opsigte is dit duidelik dat die struikelblokke groter is as wat ons gedink het.

Benewens hierdie politieke, ekonomiese en kulturele transformasies, moet modernisme ook plek maak vir postmodernisme - 'n verskynsel wat nie so maklik definieërbaar is nie, maar wat verreikende implikasies ook vir die prediking inhou. Sommige voer aan dat Suid-Afrika, trouens, Afrika as geheel, nog ligjare weg is van postmodernisme, dat ons nou eers die transformasie van premodernisme na modernisme ervaar, en dit ook maar gedeeltelik. Dit mag tot 'n sekere mate waar wees. Dit kan egter ook nie ontken word dat ons jong demokrasie deel geword het van die "global village", en dat die golf van postmodernisme wat wêreldwyd breek, onder andere ook deur middel van die kommunikasietegnologie, ook met toenemende intensiteit teen ons kuslyne aanstorm nie. Dit wil voorkom of dit 'n wesenlike saak is wat ons aandag gaan vra in die jare wat kom.

Die kritiese vrae wat vanuit die sosiale wetenskappe gevra word, is: het predikers al hierdie ingrypende skuiwe in die samelewing in hulle prediking in berekening gebring, of preek hulle maar voort soos altyd? Raak die paradigmaskuiwe in die samelewing hulle preekinhoude en -metodiek? Verstaan hulle werklik die mense wat hier aan die begin van die derde millennium voor hulle sit? Hoewel ek nie in hierdie boek indringend op die verskynsel van postmodernisme ingaan nie (vgl. wel my uiteensetting in hoofstuk 6), is dit dalk goed om hier 'n voorlopige definisie daarvan te gee, om iets van die uitdaging van dié tydsgees vir predikers te illustreer. 


\subsection{1'N DEFINISIE VAN POSTMODERNISME?}

Om die verskynsel van postmodernisme of postmoderniteit ${ }^{1}$ te definieer, is geen geringe taak nie. Trouens, sommige volbloed postmoderniste sou beweer dat ' $\mathrm{n}$ definisie van postmoderniteit ' $\mathrm{n}$ contradictio in terminis is: wie 'n greep op die verskynsel wil verkry, verstaan dit nie (vgl. Adam 1995:1). Postmoderniteit is juis "a style of thought which is suspicious of classical notions of truth, reason, identity and objectivity, of the idea of universal progress or emancipation, of single frameworks, grand narratives or ultimate grounds of explanation. Against these Enlightenment norms, it sees the world as contingent, ungrounded, diverse, unstable, indeterminate, a set of disunified cultures or interpretations which breed a degree of scepticism about the objectivity of truth, bistory and norms, the givenness of natures and the coberence of identities... Postmodernism is a style of culture which reflects something of this epochal change, in a depthless, decentred, ungrounded, self-reflexive, playful, derivative, eclectic, pluralistic art which blurs the boundaries between 'bigh' and 'popular' culture, as well as between art and everyday experience." (Eagleton 1996: vii).

Postmodernisme word inderdaad op 'n verskeidenheid maniere getakseer en "beskryf": vanuit literêre, estetiese, filosofiese, wetenskaplike, historiese, psigologiese en teologiese perspektiewe - dikwels op teenstrydige wyses (vgl. Linn 1996: xiii-xvi).

Tipiese beklemtoninge van die postmodernisme is dinge soos relativisme en pluralisme. Volgens postmodernisme is "waarheid" veelvoudig, relasioneel en onseker, het die lewe self te kompleks geword om deur 'n preek wat deur 'n individu voorberei is, enigsins deurlig of verander te word. 'n Preek is eenvoudig te skraal om die lading van 'n pluralistiese samelewing te dek. Trouens, in baie gemeentes is daar 'n groeiende diversiteit ten opsigte van spiritualiteitstipes, kerkbegrippe, wêreldbeskouings, godsdienstige persepsies, ens. Voeg hierby nog die realiteit van ouderdomsverskille, en in toenemende mate ook kultuurverskille, en prediking lyk al hoe meer na 'n onmoontlikheid!

Daarmee saam het daar ook 'n geweldige skuif in die posisie van die kerk in die samelewing plaasgevind. Die kerk is nie meer die sentrum van die dorp, die gesagsvolle stem in die regering en die alleenweter van alle waarheid nie. Prediking is nie meer vanselfsprekend nie. Dit word bevraagteken, gekritiseer, of ten minste geïgnoreer.

1 Die begrip postmodernisme verwys gewoonlik na 'n vorm van kontemporêre kultuur, terwyl met postmoderniteit' $n$ spesifieke, historiese tydperk bedoel word. Ter wille van eenvormigheid gebruik ek deurgaans die bekender term postmodernisme. Vgl. Eagleton:1996:vii e. v. 


\subsection{2 'N BEOORDELING VAN POSTMODERNISME?}

Hoe moet ons as predikers die tydsgees van postmodernisme beoordeel? Ek maak slegs drie kort, kritiese opmerkings:

- Postmodernisme is 'n tydvak, nie 'n alheilmiddel nie. Soos enige ander historiese periode bevat dit - in elk geval sover dit die prediking betref - potensiaal vir verryking óf vervlakking.

Postmodernisme is geen alheilmiddel teen die kwale van die modernisme nie, bloot 'n reaksie wat om teenreaksies roep. Dis duidelik dat die verskynsel van postmodernisme nie huidjie en muidjie deur die homiletiek gesluk, óf dat die baba met die badwater uitgegooi mag word nie. Om byvoorbeeld nét te volstaan met: "we must go to war against postmodernism inside and outside the church" (Osborne 199:112) is na my mening te min en te kortsigtig. Wat gevra word, is eerder 'n teologies-verantwoorde beoordeling en benutting van die postmodernisme. Alles in postmodernisme is nie boos nie, net soos alles in byvoorbeeld die modernisme nie goed was of is nie.

- Postmodernisme is 'n konklusie, nie 'n volledige nurve ontwikkeling nie. Postmodernisme protesteer (met reg) teen die modernisme, maar hierdie protes is, histories gesproke, lank reeds gepredisponeer. Postmodernisme is nie 'n onverwagse verskynsel uit die niet nie. Dit is eerder in 'n sin die logiese (!) konsekwensie en kulminasie van die modernisme. Dis 'n soort her- en terugskouing, 'n lykskouing, en in dié sin glad nie van die modernisme los te dink nie. Trouens, sommige volbloed postmoderniste sou waarskynlik skrik as hulle besef watter voltrekte moderniste hulle in werklikheid is! Wolfgang Welsch praat met reg van "unsere postmoderne Moderne" en waarsku teen die "Magie des falschen Namens" (1988:9-14). Daar bestaan geen waterdigte skeiding tussen die sogenaamde premodernisme, modernisme of postmodernisme nie, eerder 'n ineenvlegting, soos die ondersese yslae van ysberge wat teen en by mekaar inskuif.

Die kiem van elke epog is reeds in 'n voorafgaande en/of opeenvolgende epog teenwoordig. Wat ná die postmodernisme sal kom, is dus ook reeds in sy kern met ons.

- Postmodernisme is repetisie, nie revolusie nie. Wie enigsins 'n historiese bewussyn het, weet dat die woord van die Prediker wáár is: Wat was, sal weer wees; wat gebeur het, sal weer gebeur. Daar is niks nuuts in bierdie wêreld nie (1:9). Talle van die uitganspunte van die postmodernisme kan in ander tydvakke aangetref word, wel in 'n ander his- 
toriese baadjie, maar tog in wese dieselfde. ${ }^{2}$ Dis in elk geval 'n ope vraag hoe duursaam die postmodernisme sal wees. Sommige reken ons is al daardèur, terwyl ander meen ons het - veral in Suid-Afrika - nog nie eers daar gekóm nie. Terwyl sommige al anderkant die postmodernisme wil wees, het ander nog nie uit die premodernisme vervel nie. Dit alles roep tot nugterheid, en onderskeidingsvermoë, om te weet waarop dit werklik aankom (Fil. 1:10).

\subsection{Kritiek vanuit die kommunikasie wetenskappe}

Saam met hierdie postmoderne paradigmaskuif in die samelewing het daar ook veranderings in die kommunikasiewetenskappe en -patrone gekom. Die preek verteenwoordig volgens baie mense 'n verouderde vorm van kommunikasie. Preke is volgens hulle soos parafienlampies wat in 'n eeu van kernkrag probeer brandgemaak word! Die veranderinge in kommunikasiemedia en informasietognologie het inteendeel meegebring dat die Gütenberg-era van die drukkuns moet plek maak vir die era van die beeld en verbeelding (ek kom indringender hierop terug in hoofstuk 6).

\subsection{1. 'N KULTUUR VAN BEELDE?}

Beelde begin al hoe meer die botoon in ons samelewing voer. Vandat ons as gemiddelde (postmoderne?) mense in die oggend ons oë oopmaak, totdat ons die lig in die aand afskakel, storm die een beeld na die ander - of soms tegelykertyd - op ons af, in koorsagtige mededinging om aandag. Die oggendkoerant brand die eerste beelde in ons bewussyn in: die oorstroming in die plakkerskamp op die Kaapse vlakte; die president wat vir getroue ondersteuners wuif; die bonkige rugbyspeler wat met drie spelers om sy nek oor die doellyn beur vir sy drie.

Op pad werk toe begelei 'n beeldegalery ons: advertensieborde, verkiesingsplakkate, padtekens - saans afgewissel met neonligte wat flik-

2 Byvoorbeeld: Word die postmoderne beklemtoning van relatiwiteit nie al vroeër deur die Griekse filosoof Heraklitus verwoord met sy panta rei nie (letterlik: alles vloei; realiteit kan nooit gefikseer word en daarom ook nooit gedefinieer word nie)? En, het die Joodse tradisie van midrash nie al lank terug (baie mooier!) gesê dat daar 'n multidimensionaliteit van teksbetekenis is nie? Word tekste nie juis in die Judaïsme vereer ten opsigte van hulle teenstellings, paradokse, ironieë en skandaligheid nie? Vgl. Janse van Rensburg 2000:13; ook Brueggemann 1993: 55 e. v. 
kerend hulle boodskappe vir ons knipoog. As ons by die werk die rekenaar aanskakel, neem die ikone ons op 'n toer die kuberruimtes in, waar klank en kleur, beeld en beweging nuwe wêrelde voorhou en oopvou: eendimensioneel, tweedimensioneel, driedimensioneel, multidimensioneel - wie weet waar dié "virtuele realiteit" nog gaan eindig?

Saans neem ons soos verslaafdes ons plekke voor die "beeldboks" in. In sy flikkerende lig sien ons die ellendes van ander mense in ander kontinente, beelde van vegtende faksies in die Midde-Ooste, of honger kinders wat kosbakke met knokkelrige hande en groot, vraende oë na jou toe ophou. Gelukkig is dié beelde van korte duur, en kan ons ons regskuif vir 'n beeld uit die buiteruim, 'n satellietblik op ons blou planeet, gepaard met die weervoorspellings vir die dag.

Beelde het feitlik elke ruimte van ons bestaan ingeneem. Ook die sogenaamde "ongerepte" ruimtes word daardeur gekontamineer - die konsumpsie-ikone van die advertensiewese bly soos goeie bloedhonde op ons spoor. Die strand roep beelde van sonbruin lywe en Ambre Solaire sonroom op; die wuiwende koringlande impressies van Weetbix-etende families; die plaas-stal met die ou Ford-bakkie wat aangery kom, herinneringe aan sweterige mense wat Coca-Cola afsluk. Selfs die mees intieme ruimtes word betree: die kraamsaal word 'n lanseerplatform vir 'n pasgebore baba se naelstring-reksprong; die begraafplaas die agtergrond vir 'n herinnering aan die noodsaaklikheid van lewensversekering.

Van die wieg tot die graf, van die oggend tot die aand, ja, van die een seisoen van ons lewens tot die volgende, bly die beelde op ons spoor, roep dit ons, lok dit ons - en nie altyd ten goede nie.

Harvey Cox het al hierteen gewaarsku. Hy skryf in 1969 oor die neonkultuur: "...it relies on sensory overload. It induces a different dimension of awareness, not by depriving the senses of stimuli, but by pounding the senses with so many inputs and at such speed that the normal sorting mechanisms cannot cope... The effect is quite accurately described by the phrase, 'mindblowing"” (1969:109). Dis inderdaad die ironie van ons tyd: terwyl ons omring word deur beelde, word verbeelding, oftewel kreatiwiteit, in sy diepste kern bedreig (Kearny 1988: 3).

Beelde begin by die werklikheid oorneem. Dit gaan aan die werklikheid vooraf wat dit veronderstel is om uit te beeld. Trouens, die werklikheid het maar 'n bleek afskynsel van die beeld geword. Dit sien 'n mens op verskillende vlakke van die samelewing.

In die politiek is dit dikwels die media-kampanje wat die man of vrou máák. Politici word dikwels verkies op grond van die media-beeld (opgeblaas en onrealisties) wat van hulle gechoreografeer en só voorgehou word dat die stertjie van die beeld die hondjie van die realiteit 
swaai. Nuusberigte kan só sensasioneel verpak word dat die molshopie nie net 'n bergie nie, maar Mount Everest word. In die ekonomiese wêreld is dit 'n algemene reël: skep die behoefte deur beelde en nogmaals beelde van "suksesvolle" en "gelukkige" mense wat die goue, geadverteerde produk gebruik. Trouens, in ons konsumpsie-samelewing het die advertensiewese 'n uiters gespesialiseerde wetenskap geword: om die realiteit (behoeftes) te skep deur strategies-beplande, maar dikwels vir die blote oog verborge kodes, of gewoon deur massiewe advertensieveldtogte wat mense teen wil en dank moet oorreed om tot die produk tot bekering te kom.

Die ironie is: ons het afgestomp geraak, in elk geval vir dié beelde wat werklik sáák maak. Slegs af en toe kom daar 'n beeld oor ons pad wat ons uit ons ikoniese beneweldheid tot ons sinne roep. Die blote noem van 11 September 2001 roep so 'n beeld voor die geestesoog op. Wie sal die spuitvliegtuie vergeet wat soos brandende missiele deur die tweelingtorings van die World Trade Centre in New York gebars het? Woorde kon so 'n gebeurtenis nie beskryf nie. Dit was te verskriklik vir woorde. Beelde moes die volle grusaamheid daarvan aan ons ontvou - en is ook deur eindelose herhaling op al wat 'n televisie-kanaal is, by ons ingeprent.

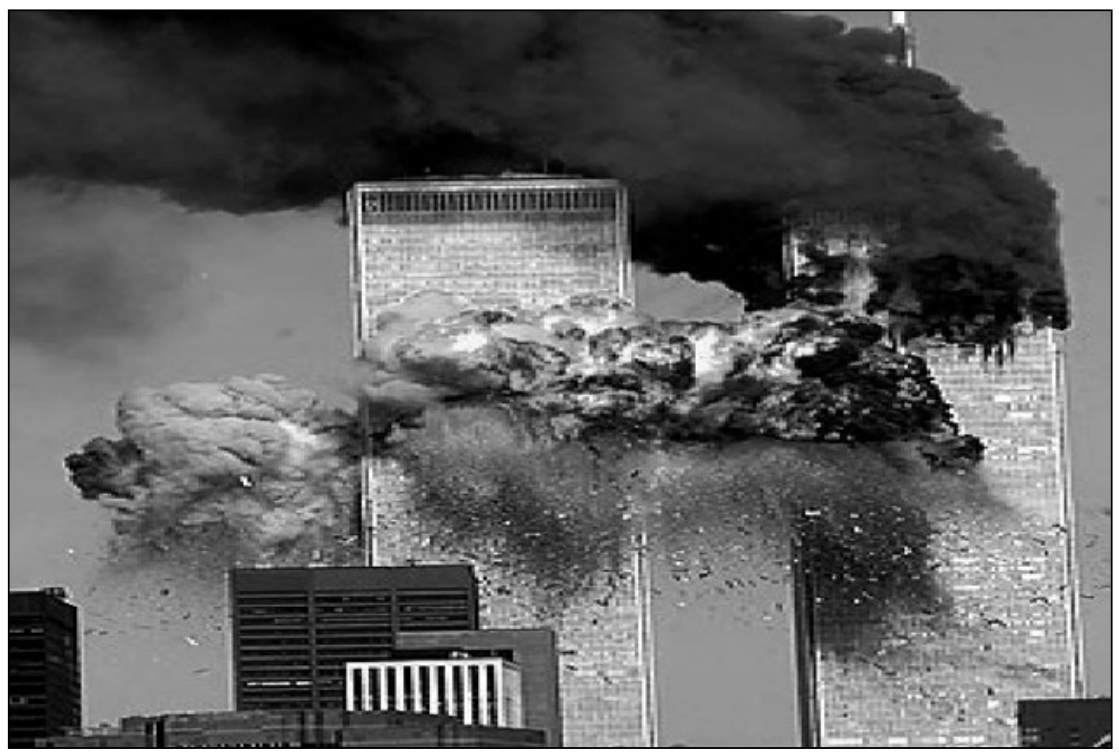

My kinders het op eie inisiatief kort daarna prentjies daarvan geteken. Dit was duidelik dat die indruk van die vliegtuig wat deur die wolkekrabber 
vlieg, 'n soort ikoon van hedendaagse stedelike terreur, ja, van globale terrorisme vir hulle geword het. ${ }^{3}$

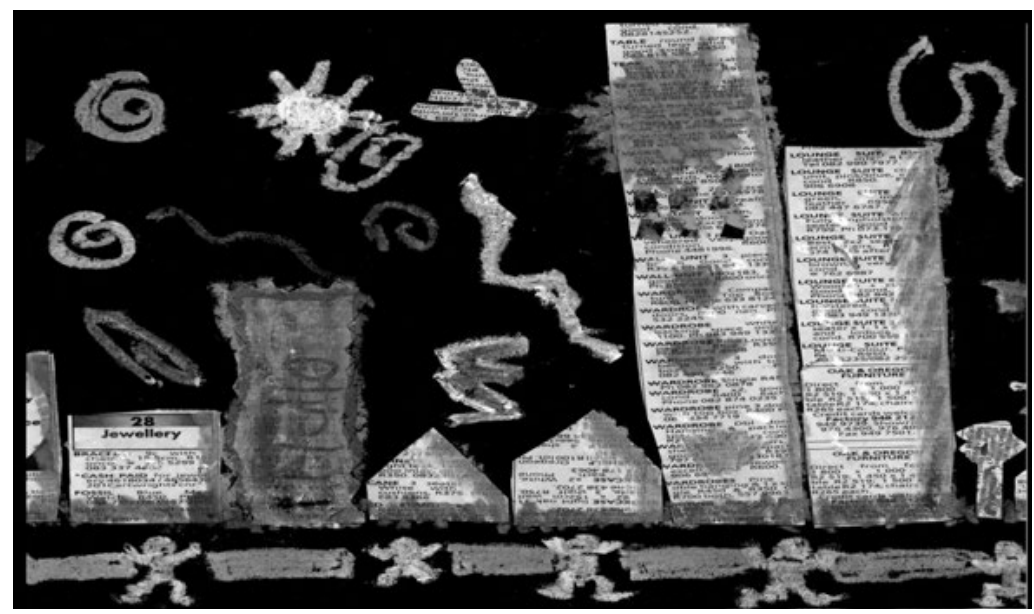

Die wêreld het inderdaad klein geword. Globale beelde mak hulle verskyning in ons televisiekamers. En dit is nog maar die ore van die seekoei. Waarnemers voorspel dat die volgende vyf tot tien jaar 'n informasie-tegnologiese ontploffing gaan meebring soos nooit tevore nie. Die internet gooi sy web al hoe wyer en dieper in die kennispoel in. Rekenaars word al hoe kleiner, vinniger, effektiewer. Selfone word sentra vir feitlik alle vorme van kommunikasie. Gaan ons later álles wat ons nodig het om getroos te kan lewe en sterwe met die druk van 'n enkele knoppie op ons horlosies/persoonlike mikroskyfies kan bewerkstellig?

Die Gutenberg-era van die gedrukte media is vir sommige inderdaad byna al net 'n herinnering: die kultuur van die boek word vervang met die kultuur van die beeld. Trouens, sommige beweer dat ons 'n era betree waarin die kuns om te lees 'n anakronisme mag word, weinig meer as 'n nostalgiese luukse (vgl. Kearny 1988: 2). Die eeu van die geskrif moet plek makk vir een van uitbeelding. Konsepte word vervang deur ikone; begrippe deur die visuele. Konseptuele taal vervaag ten gunste van simboliese taal. Pierre Babin (1991: 150-151) druk dié klemverskuiwing met die volgende diagram uit:

3 Daar bestaan natuurlik ook heelwat ánder interpretasies van hierdie gebeure. Billy Graham het die val van die World Trade Centre byvoorbeeld met die val van die toring van Babel (Gen. 11) vergelyk. Die beeld van die Bybel word dus hier gebruik om die beeld van die koerant en televisie op 'n manier te ontmitologiseer! 


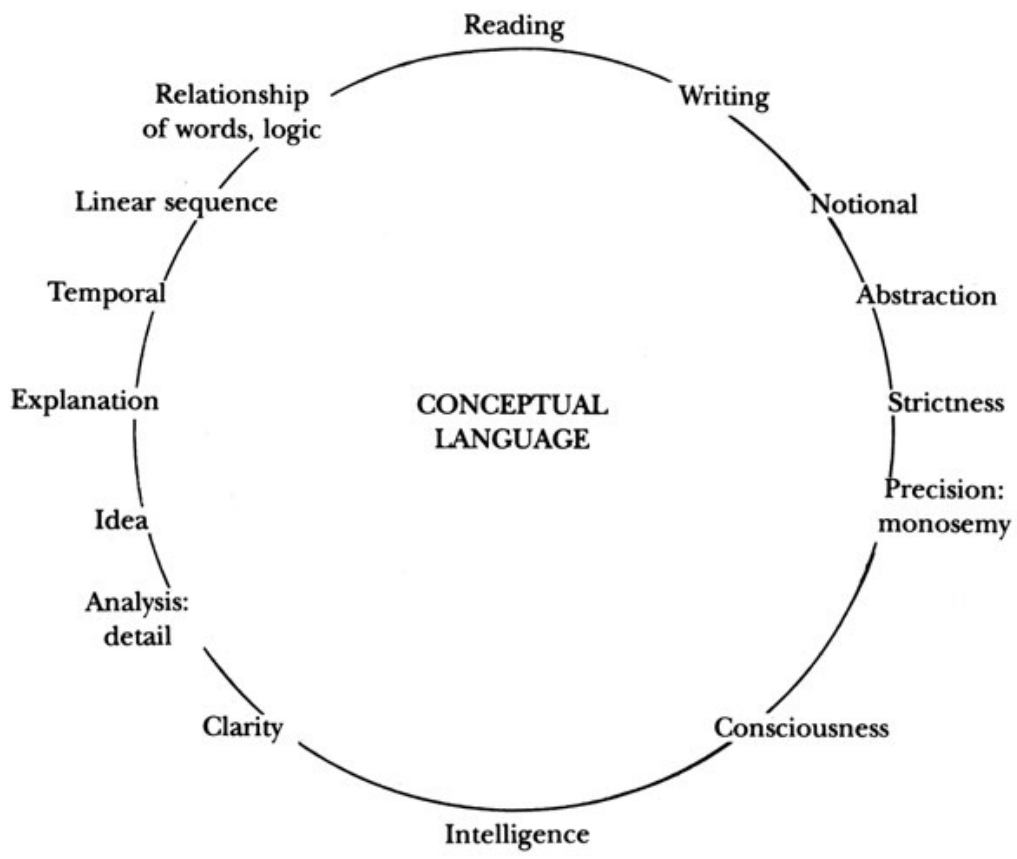

Knowledge by

participation and immersion

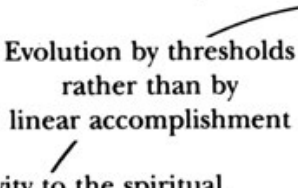

Sensitivity to the spiritual and to occult forces<smiles>C1CC1</smiles>

Recognition

SYMBOLIC

of wholes

LANGUAGE

Analogical bonds

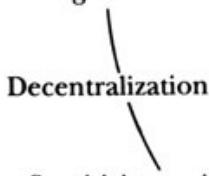

Sensitivity to signs and indicators

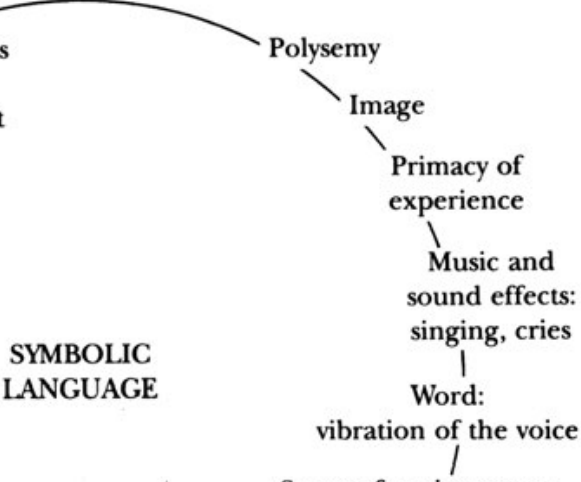

Sense of environment: space, architecture I

Global perception

Emotional knowledge:

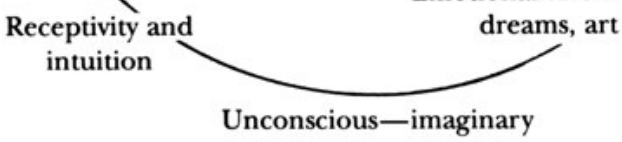


Kortom: "warm” kommunikasie moet plek maak vir koel (“cool” !) kommunikasie (McLuhan). Dit beteken onder meer: preke wat wesenlik logiessekwensieël en liniêr is, moet plek maak vir ander, intuïtiewe en deelnemende vorme van kennisoordrag.

Tradisionele preke is volgens hierdie kritiese stemme heeltemal te monologies. Monoloë is inderdaad die slegste vorm van kommunikasie denkbaar, hoewel ek huiwerig sou wees om die preek saam met $\mathrm{R}$ White te wou definieer as "a monstrous monologue by a moron to mutes"! Wat gevra word, is 'n dialoog, 'n diskoers binne die ruimte van die gemeente en die ekumene (vgl. verder hieroor hoofstuk 5).

Navorsing toon buitendien aan dat tradisionele preke oënskynlik 'n lae graad van effektiwiteit het. Behalwe dat min mense selfs net die basiese boodskap kan onthou of verwoord, is die aantal wat daardeur verander word, blykbaar nog minder. Die tyd het gekom - só lui die kritiese stem uit die hoek van die kommunikasiewetenskappe - dat die formaat van die prediking drasties, en veral verbeeldingryk, moet verander.

Dit wil egter voorkom as dit juis nie gebeur nie. John Bluck, 'n kommunikasiewetenskaplike, maak die opmerking dat die prediking op feitlik al die wesenlike punte van goeie kommunikasie besig is om die stryd te verloor, en trouens presies omgekeer word:

- as openbare gebeure (die prediking verloor al hoe meer betekenis vir die breë publiek, verloor sy "public appeal");

- as kunsvorm wat meer as een gestalte kan aanneem (die prediking word al hoe meer eenvormig en gewoon vervelig);

- as gebeurtenis wat plaasvind ter wille van, en in 'n sin behoort aan die gemeente (die prediking word in toenemende mate individualisties, word die "eiendom" van die prediker);

- as 'n daad van geloof waarin die prediker se eie oortuiginge ook op die tafel geplaas word (die prediker word 'n "professionele" redenaar, wat die boodskap "objektief” as kerklike funksionaris kan oordra) (1989: 33).

\subsection{Kritiek vanuit die teologiese wetenskappe}

Sommige teologiese kritici wys daarop dat die prediking (nog steeds) te veel vanuit die sogenaamde Woord-teologie van Barth verstaan word. Predikers verloor dus - volgens hierdie siening - die menslike en kommunikatiewe kant van prediking uit die oog. Gee te min aandag aan die werklike mense wat voor hulle sit, en die werklike kontekste wat deur hierdie mense in die preekoomblik ingebring word. En sonder twyfel is dit so: prediking wat die konteks van menswees nie in die oë kyk nie, 
is in werklikheid nie prediking nie (vgl. verder hoofstuk 5).

Ander wys daarop dat die verskynsel van moralisme steeds hoogty in die prediking vier. Dit keer blykbaar keer op keer in ons prediking terug, en het oor jare heen talle mense só gekondisioneer dat dit 'n vraag is of hulle nog die evangelie (kan) hoor? Voeg daarby die feit dat tradisionele prediking meestal kerklik-introverties van aard is, en die preekmoegheid pak jou sommer by voorbaat beet - veral as jy 'n onderskeidende luisteraar van preke wil wees. Tradisionele preke handel immers hoofsaaklik oor die religieuse behoeftes van enkelinge of moontlik gemeentes, maar spreek nie noodwendig die wyer etiese en sosiale nood en sake van die dag aan nie. Hierdie toedrag van sake gaan weer hand aan hand met die verskynsel van moralisme. Moralistiese preke is trouens altyd oneties. En só word daar inderdaad meestal (kerklik-institusioneel) gepreek.

So ver terug al soos 1959 hoor ons G Ebeling sug oor wat hy noem hierdie institusioneel gewaarborgde banaliteite: "We hoeven alleen maar onze eigen ervaringen rustig te bekijken om tot de conclusie te komen dat we een zekere mate van goede wil moeten meebrengen voor de doorsnee-preek, als we tenminste niet verveeld of nijdig, sarcastisch of melancholiek willen worden. Wat een moeite wordt er door het bele land besteed aan de prediking van het christelijk geloof. Maar zijn het - met enkele uitzonderingen - niet institutioneel gewaarborgde banaliteiten die we boren?" (aangehaal uit K Runia 1981, 9)

Maar hier hou die teologiese kritiek nie op nie. In teologiese en kerklike kringe woed tans veral die debat rondom Skrifgesag (vgl. ook verder hoofstuk 4). Dit roep ingrypende vrae vir die prediking na vore, byvoorbeeld: Kan die Woord werklik (nog) gepreek word? Wat is waar en wat nie? Is die Bybel onfeilbaar? Hierdie en derglike vrae laat mense wonder: Is daar'n verlies van vertroue in die evangelie? Of in predikers? Of in die kerk? Dié onsekerheid word verder aangeblaas deur die wydverspreide aandrang om liturgiese vernuwing, wat as sodanig nie verkeerd is nie, maar wat soms meebring dat die prediking maklik kan verskrompel tot 'n verkleinde addendum agteraan die liturgie. Die vraag wat baie vra, is: Pas die preek régtig nog in?

Maar, dalk bly die diepste teologiese kritiek steeds die aard van die evangelie self. Dit bly immers, soos reeds vermeld in die inleiding tot hierdie boek (1.1) 'n skandaal (skandalon), 'n toonbeeld van die uiterste, mislukte kommunikasie tussen God en mens (Bohren). Die evangelie is nie per se "suksesvol" nie. Hoe kan die prediking dan verwag om suksesvol te wees?

\subsection{Kritiek uit die kerkbanke}

Miskien is juis dít die mees vernietigende kritiek wat gehoor móét word en wat predikers die minste van almal wíl hoor. Talle lidmate, ook 
gelowige, toegewyde lidmate, verklaar onomwonde: prediking is gewoon vervelig, irrelevant en teleurstellend. Talle lidmate stem met hulle voete en verlaat die kerk. Dit kan gebeur vanweë geldige, maar ook minder geldige redes. Punt is: dit gebeur. Mense is moeg vir baie woorde en soek in 'n era van kitsoplossings en kitskommunikasie na 'n kitsevangelie. Of in elk geval na iets anders as wat hulle in die kerk beleef.

Laat ons reguit hieromtrent wees: talle lidmate is ontnugter met die kerk. En laat ons maar toegee: ons - die dominees en die kerk - het nie juis 'n geskiedenis van "suiwer uitleg" van die Woord nie! Inteendeel - ons het die evangelie maar al te dikwels laat aanpas by óns agendas en óns oortuigings. Die onlangse ideologiese ondersteuning van byvoorbeeld apartheid sit immers nog vars in ons geheue. Om redes soos hierdie vra mense: Wie sê dominees preek nou die waarheid?

Hang hierdie vrae dalk saam met 'n oordrewe verwagting van die prediking? Of met die gebrek aan besef dat die prediking slegs 'n onderdeel van 'n groter geheel (van die erediens en die gemeentelewe) is? Wat ook al die geval, die misnoë oor die prediking is blykbaar aan die toeneem. Lidmate kla dat die erediens op 'n Sondag nie raakpunte met hulle lewens in die realiteite van elke dag het nie. Dat daar geen kontinuïteit van Sondag na Sondag is nie. Dat predikante die gemeente as gehoor totaal onderskat, en hulle soos geestelike kinders hanteer, of totaal oorskat, en hulle met groot, religieuse woorde vermoei. Dis duidelik dat die klagtes uit die kerkbank vermenigvuldig kan word. Die lied van Stef Bos, Pepermunt, is dalk eensydig, maar dit brand bitter op jou tong:

\section{Het word gefrabiceerd in Friesland \\ Het beeft een koninklijke naam \\ Er zijn natuurlijk andere merken \\ Maar deze beeft de meeste faam}

Je kunt er lekker lang op zuigen

Bijt je tanden er op stuk

En als ik vroeger in de kerk zat

Was bet mijn redding en geluk

\section{Pepermunt}

Pepermunt

Als de preek je gaat vervelen

Als je niet meer luist'ren kunt 
Pepermunt

Pepermunt

Het is de protestantse cocaïne

Voor de gereformeerde junk

Als de dominee op dreef was

Tegen oorlog en geweld

En als $i k$ alle kleine ruitjes

Van het kerkraam had geteld

Dan greep mijn moeder in haar handtas

Voor het juiste medicijn

En ze gaf me witte pillen

En die verzachten alle pijn

Pepermunt

Pepermunt

Als de preek je gaat vervelen

Als je niet meer luist'ren kunt

Pepermunt

Pepermunt

Het is de protestantse cocaine

Voor de gereformeerde junk

Het is de protestantse bostie

De gereformeerde drugs

En als er nooit een kerk geweest was

Dan was er ook geen

P-p-p-p-p..... pepermunt

Als de preek je gaat vervelen

Als je niet meer luist'ren kunt

Pepermunt

Pepermunt

Het is de protestantse cocaine

Voor de gereformeerde junk

Of, dalk word die onbehae met die prediking nog die beste geformuleer deur 'n dogtertjie wat vyf minute in die preek in met 'n helder stemmetjie vir haar ma fluister: "Ag ma, betaal die man nou dat ons kan loop." 


\subsection{Pastorale faktore}

Asof bogenoemde kritiese stemme nie al genoeg is nie, klink daar ook nog stemme, nee, eerder versmagtinge, uit die hart en gemoed van die dominees sélf op. Van die mees algemene sugte lui so: Hoe kan ek Sondag regtig preek, as daar soveel (ander, soms onmenslike) eise aan predikante gestel word? Is dit fisies en emosioneel moontlik om binne die huidige struktuur van kerkwees en programme van die dominee werklik reg aan die prediking te laat geskied? Toe die biskop van die grote Augustinus hom gevra het of hy nie op Paassondag wil preek nie, het hy volgens oorlewering reeds in Januarie om verlof aansoek gedoen - om grondig te kan voorberei vir sy preek! Die meeste van ons dominees het nie die luukse van sulke lang vakansies nie, en is helaas ook nie die woordryke Augustinus nie. Maar Sondag na Sondag moet ons maar op die kansel klim en woorde vind om God se Woord aan ander mense te verwoord...

Predikante is mense, nie engele nie - al dink ander mense, en helaas, af en toe ook die dominee sélf! - by geleentheid só. Faktore soos die selfbeeld en die beperkte insigte van die prediker, asook sy of haar persoonlikheidstipe kom in spel. Partykeer worstel die prediker met die ervaring dat hy of sy niks in die Bybelse teks of van die Here gehoor het nie, en tog Sondag moet preek! Hoe sê jy elke Sondag iets nuuts...?

Hoe verkondig jy die rykdom van die evangelie wanneer jou prediking dikwels bepaal word deur dít wat in jou lewe as mens en as prediker gebeur? Hoe kompeteer jy met ander, skynbaar oneindig effektiewer kommunikasiemedia? Hoe bestuur jy byvoorbeeld die spanning tussen die informasie-tegnologie van die derde millennium (televisie, "powerpoint", WebCt - en voeg maar by!) en die werk van die Gees? Waar pas jy as prediker in? (Vir 'n uitgebreide bespreking van die rol van die prediker in die preekmaakproses, lees verder by hoofstuk 6)

Maar, eers genoeg van die kritiese stemme en vrae. Miskien het dit tyd geword dat ons weer 'n slag sal terugkeer na die basiese uitgangspunte en definisies rondom die prediking, dat ons vir onsself sal uitmaak: Wat dóén ek as ek preek? Wat verwag ek van die preek? Wat glo ek in verband met die preek? Ja, wat op aarde ís 'n preek? Waarin lê die geheim daarvan? In die volgende hoofstuk staan ons by hierdie en derglike vrae stil.

Voordat ons egter by die tweede hoofstuk kom, wil ek graag hier, as vertrekpunt, my eie oortuigings aangaande die prediking verwoord. Hiérin vind ek onder meer, veral te midde van die kritiese stemme, troos! 


\subsection{Prediking: Die hart en die hoop van die kerk}

\subsubsection{PREDIKING: DIE HART VAN DIE KERK}

Ek glo dat die prediking steeds 'n belangrike funksie het om in die bediening in en deur die gemeente te vervul. Die kerk sou geweldige skade lei as die prediking op een of ander manier gedevalueer of afgeskeep sou word, indien ons in ons pogings om te vernuwe nie ook grondig na die prediking sou kyk nie. Trouens, navorsing het getoon dat die prediking basies en sentraal in die opbou van die gemeente is, dat opbou nie sonder die prediking kán gebeur nie (Nel 2001:5). Die prediking moet wel nie oorskat word nie, maar dit moet ook nie onderskat word nie. Die gemeente is meer as die erediens, en die erediens is meer as die preek. Preke is slegs kort, beskeie tekste, maar dis verbindende tekste tussen die Bybelse getuienisse van wat God gedoen het, maar ook tussen die dade wat Hy tans in ons midde doen (Den Dulk 1999: 28).

Die prediking is wesenlik vir die welwese van die kerk, en tog wil dit voorkom, soos ek reeds in die voorafgaande aangetoon het, asof daar juis ten opsigte van die prediking 'n degenerasie aan die plaasvind is.

Hierdie degenerasie is ' $\mathrm{n}$ hartseer realiteit, maar tog sou ek die prediking steeds die hart van die kerk (Luther: cor ecclesiae) wou noem. Preke is 'n vertoonvenster, of ons nou daarvan bewus is of nie. Dit bly juis 'n soort barometer van die kerk, wat die gesondheidstoestand van die kerk verraai. 'n Mens sou met reg kon sê: só prediking, só kerk; só kerk, só prediking. In konkrete preke kulmineer baie dinge: predikers se dogmatiek, etiek, Skrifbeskouing, historiese bewussyn, pastorale en eksegetiese vaardighede, hermeneutiese vermoëns, psigiese, emosionele en geestelike volwassenheid en nog veel meer. Konkrete preke skilder 'n reënboog van teologiese en kerklike (en daarom menslike!) aktiwiteite - kleurvol en opwindend, of vaal en vervelig. Dit kan óf getuig van regenerasie, óf van degenerasie.

\subsubsection{PREDIKING: 'N HoOPVOLle HANDELING}

As basiese uitgangspunt bely ek: ek gló aan die prediking. Ek glo, ten spyte van al die kritiese stemme wat ons sover gehoor het, dat die prediking een van die mees hoopvolle handelinge is waarvan ons deel kán wees. Trouens, om te preek, is om te hoop. Die prediking is ' $n$ gekonsentreerde vorm van die Christelike hoop. Dit geskied dikwels ten spyte van die oënskynlike afwesigheid van resultate, dikwels teen skynbare oorweldigende magte en faktore in, dikwels bloot as 'n daad van volharding, van volgehoue hoop. Hoopvolle prediking leef uit 'n aantal verwagtings, byvoorbeeld: 
- Dat die prediking inderdaad mense kan verander. Een van Luther se bekendste uitsprake lui: die Woord van God kom om ons te verander. Hierdie getuienis tref 'n mens ook in die Skrif aan, hoewel ons nie hier van prediking in die gebruiklike sin van die woord kan praat nie. Die verkondiging van die Woord neem in die Skrif verskillende gestaltes aan, byvoorbeeld as korter getuienisse aangaande Christus, langer uiteensettings aan groter gehore, of basiese, apostoliese belydenisse oor die Heerskappy van Jesus van Nasaret. Die basis van hierdie prediking is uiteraard ook nie die totale Skrif soos ons dit nou ken nie, maar hoofsaaklik die Ou Testament, orale getuienisse oor die lewe, sterwe en opstanding van Jesus, en moontlik enkele, eerste Nuwe Testamentiese geskrifte. Wat ook al die geval, die prediking dien die voortgang van die evangelie deurdat dit mense verander. Wanneer Petrus sy preek op die eerste Pinksterdag lewer, word die mense diep getref, en vra hulle: "Wat moet ons doen?" (Hand. 2:37) Wanneer Filippus die evangelie in Samaria verkondig, kom 'n hele stad in beroering, en volg groot blydskap (Hand. 8:4-8). Wanneer Paulus Christus in Filippi verkondig, maak die Here 'n vrou met die naam Lidia vir sy woorde ontvanklik (Hand. 16:14). So sou ons kon aangaan. So was dit ook in die loop van die kerk se geskiedenis: die prediking bly steeds 'n instrument waardeur God mense verander.

- Dat die prediking nie 'n leë woord is nie, maar 'n woord waarin God self ter sprake kom, dit wil sê waarin Hy self teenwoordig en werksaam is. Hierin lê waarskynlik ons diepste hoop wanneer ons preek. Op een of ander wyse, dikwels verborge, tree God mense deur die prediking tegemoet. Wanneer Petrus praat oor die gawes in die gemeente, onder meer ook die gawe om te kan preek, voeg hy daaraan toe: As iemand die gawe ontvang het om te preek, moet God deur hom aan die woord kom (1 Pet. 4:11). Die OAV vertaal: moet jou woorde soos woorde van God wees. Dis egter belangrik dat hierdie, en dergelike uitsprake, nie op 'n meganiese of outomatiese wyse verstaan moet word nie. Eerder as 'n belydenis, en daarom ook as 'n oproep, ja, 'n versugting en 'n gebed dat dit inderdaad só sal wees. Gebed bly die diepste struktuur van alle boopvolle prediking - 'n waarheid wat ek telkens in die loop van hierdie boek gaan herhaal.

- Dat die prediking mag bydra tot die openbaarmaking van die (geopenbaarde!) geheimenis van Christus (vgl. Kol. 4:3). Prediking waarin God self ter sprake kom, is altyd trinitaries, maar omdat God die verlossende God is, sal die prediking oor sy verlossingswerke ook altyd Christosentries wees. Hierin bestaan geen teenstrydigheid nie, eerder 'n inherente, teologiese verband. Die apostoliese prediking van die Nuwe Testament vind byvoorbeeld altyd sy fokus in die gebeure rondom Christus. Dit is Gód wat in Christus handel; die Vader wat sy hart 
openbaar; die Gees wat dit bevestig. Daarom kan Paulus sonder skroom verklaar dat dit sy voorneme was om met die Korintiërs oor niks anders te praat nie as oor Jesus as die Christus, en wel oor Hom as die gekruisigde (1 Kor. 2:2). As Luther sê dat ons niks ander as Christus mag verkondig nie, bedoel hy ook: na Christus toe loop alle lyne, en van Hom skiet alle strale uit. Hierin - in die verkondiging, en daarom ook teenwoordigheid van Christus - lê die konsentrasie van alle hoopvolle prediking. Immers, Christus is ons boop (1 Tim. 1:1; vgl. ook verder hoofstuk 3).

Om saam te vat: ek glo dat prediking een van die wesenlikste gebeurtenisse is wat kán plaasvind in ons wêreld en tyd. Lloyd-Jones (1976:9) is reg wanneer hy verklaar:

"Preaching is the highest and the greatest and the most glorious calling to which anyone can ever be called... the most urgent need in the Christian Church is true preaching; and as it is the greatest and the most urgent need in the Church, it is obviously the greatest need of the world also."

Aan ons as predikers is, tesame met die hele kerk, woorde toevertrou wat die wêreld dringend nodig het, en, bewus of onbewus, na hunker. Soms mag mense vir ons lag, ons bespot en verwerp, maar ons het woorde ontvang wat al die verskil mak. Vanuit hierdie oortuiging skryf ek hierdie boek.

Sonder die Esel aan die kruis, is die wêreld verlore. 


\section{Die geheim van die prediking: een-stemmigheid op die kansel}

In hierdie hoofstuk word daar probeer om 'n voorlopige definisie van die prediking te gee, deur te let op:

- Die vier basiese elemente van die prediking, asook

- Die verhouding tussen bogenoemde vier elemente in terme van die begrippe stem en spel

\section{1'n Besoek aan 'n kunsgalery...}

Wat is 'n preek? Hoe definieer jy dit? Miskien moet ons, om hierdie vrae te beantwoord, 'n besoek aan 'n kunsgalery bring - iets wat ons meermale in hierdie boek gaan doen. Die galery is in hierdie geval 'n kerk, die bekende Stadkirche in Wittenberg, Duitsland, waar ons 'n boeiende altaarkomposisie aantref, geskilder in 1565 deur Lucas Cranach (senior). Die tema op die spesifieke onderdeel van die komposisie waaraan ons aandag skenk, is 'n uitbeelding van Martin Luther wat besig is om te preek.

Dis 'n merkwaardige uitbeelding: al die basiese elemente van die prediking word hier op 'n estetiese wyse byeengebring. Hierdie elemente of konstituente is dít wat die prediking prediking máák; daarsonder -selfs sonder een van hierdie elemente - is daar nie sprake van prediking,in elk geval in die klassiek Christelike sin van die woord nie.

- Die eerste element wat ons aandag vra, is ook die fokuspunt van die skildery: Christus, die Gekruisigde. Die wyse waarop die lendedoek rondom Hom gedrapeer is - dit lyk byna asof dit in die wind wapper suggereer egter alreeds die wonder van die opstanding: die krag daarvan ruk alreeds aan die liggaam van die Gekruisigde. Immers, die Gekruisig- 


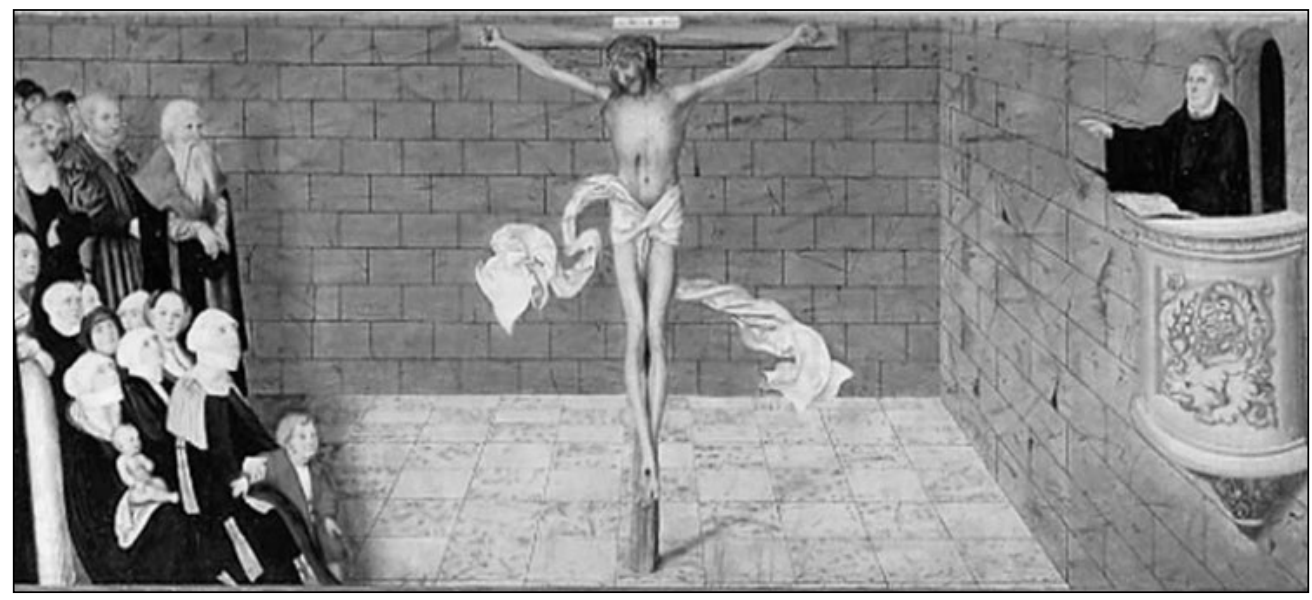

de is ook die Opgestane, net soos die Opgestane die Gekruisigde is. Hierdie fokuspunt van die skildery illustreer twee wesenlike aspekte van die prediking, naamlik:

- dat dit altyd prediking van die evangelie, dit wil sê van die verlossende handelinge van God is, met die crux daarvan in die Gekruisigde, Opgestane Christus (vgl. verder hoofstuk 3),

- dat die Een wie se Naam in die prediking uitgeroep word, daadwerklik dáár is. Die prediking is nie 'n leë woord nie, maar 'n gevulde Woord, 'n woord-gevul-met die Woord.

- Die tweede element van die prediking wat in die skildery uitgebeeld word, is die oop Bybel wat voor Luther, die prediker, lê. Die Een wat uitgewys word, is naamlik die Een waarvan in die Skrif getuig word. Dié twee - die getuienis en die Betuigde - staan in geen spanning met mekaar nie, trouens, in die korrelaat lê onder meer die geheim en krag van die prediking. In 'n sekere sin sou ons kon sê: in die mate waarin die geboekstaafde getuienis van die Skrif in die prediking tot sy reg kom, word die Betuigde sigbaar. Die letter sonder die Gees is dood, ja, maar die Gees maak wel die letter, hierdie spesifieke letter wat ons die Heilige Skrif noem, lewend (vgl. 2 Kor 3:6). Sonder die letter waardeur die Gees werk, is prediking ondenkbaar en onmoontlik (vgl. verder hoofstuk 4).

- Die derde konstituent van die prediking wat in hierdie skildery uit die verf kom, is die gemeente. Hulle oë is nie (in die eerste plek) op die prediker gerig nie, maar op die Gekruisigde en Opgestane Christus. Dis 'n spesifieke gemeente wat hier uitgebeeld word, nie fiktiewe of 
ideale mense nie, maar mense wat tot 'n bepaalde tyd, plek en kultuur behoort. Hulle bring 'n spesifieke konteks in die prentjie in. Die woorde van die prediker kom in hulle taal en begripveld, binne hulle bevatlikheidsvermoë en idioom tot hulle. Hulle verstaan wat gesê word. Die Gekruisigde en Opgestane Christus word só aan hulle bemiddel, dat die woorde oor Hom in 'n visie van Hom omgesit word. Hoor word sien, 'n sien wat sin maak in en vir hulle lewens, en 'n verskil bewerkstellig in hulle spesifieke situasies van nood (vgl. verder hoofstuk 5).

- Die vierde element is die prediker self. Prediking sonder 'n prediker is onvoorstelbaar. Sy en haar funksie is om - soos Luther op die skildery - na Christus weg te wys. Die prediker wat op die kansel staan, is 'n mens, nie 'n engel nie. Iemand wat ook tot 'n spesifieke tyd en kultuur behoort, en 'n bepaalde taal praat. Iemand met 'n geskiedenis, 'n hede en 'n toekoms. Met 'n persoonlikheid en 'n spiritualiteit. Iemand wat wel deel is van die gemeente, en as sodanig saam met die gemeente na Christus, die fokuspunt kyk, maar tog ook in 'n sin eenkant geplaas is, amptelik afgesonder is om 'n prediker te wees. Die geheim van hierdie amp is om nie die uitsig op Christus vir die gemeente te versper nie, nie tussen Christus en die gemeente te kom nie, maar 'n bemiddelaar te wees, 'n uitwyser (vgl. verder hoofstuk 6).

Dus: in die skildery sien ons die Gekruisige, Opgestane Here - die Verlossende God self, die Bybelse teks, die gemeente en die prediker: in hierdie vier elemente lê die geheim van die prediking. Die verhouding tussen hierdie elemente bepaal die prediking. Die wonder van die prediking vind naamlik plaas wanneer daar 'n konvergensie is, 'n gebeure-deur-die-Gees; wanneer hierdie vier elemente só saamval dat God Homself deur sy Woord en deur'n prediker aan 'n gemeente openbaar. Hierin, in hierdie een-stemmigheid, hierdie samespel, lê die belofte en uitdaging van dit wat ons prediking noem. Binne hierdie matriks, hierdie viervoudige relasie, kan die wonder waar word dat die woorde van die prediking woorde, en Woord, van God word.

\subsection{Woorde, woorde, woorde ...}

Daar word vertel dat die bekende humoris Mark Twain by geleentheid in die kerk was en ná afloop van die diens vir die dominee gesê het: "Ek het bierdie preek van $u$ al vantevore geboor. Trouens, ek het dit al 'n páár keer gehoor." Die dominee het dadelik begin om homself te verweer en geantwoord: "Nee, dis onmoontlik. Al my preke is oorspronklik. Ek bet bierdie preek die afgelope week self met groot moeite gemaak, en dit vandag vir die eerste keer gepreek. U het dit beslis nog nie vantevore gehoor nie." 
"Ons sal sien" het Mark Twain met die kenmerkende vonkeling in die oog opgemerk en is daar weg. Die volgende dag daag daar'n pakkie by die dominee se voordeur op, netjies toegedraai. Toe hy dit oopmaak, sien hy dat dit 'n dik woordeboek was. Bo-in het Twain 'n stukkie papier gesit waarop geskrywe was: Woorde, net woorde, net woorde...

Die dominee het met die woordeboek in sy hand gestaan, en skielik was hy sónder woorde. Hy het geweet: Twain is reg. Ons preke bestáán uit woorde. Meestal mooi woorde, belangrike woorde, goedgekose woorde. Uit 'n sekere perspektief gesien, sou ons selfs moes sê: ons preke is niks ánders as 'n redevloed, as 'n stroom woorde wat ons monde verlaat en op die koppe en in die ore van ons toehoorders neerreën nie. Dit kan ook nie anders nie: waar gepreek word, kom woorde ter sprake. Wie op die kansel klim, klim primêr daarop om te práát, om die woord te voer.

Maar... is dit ál? Bestaan ons preke bloot uit woorde, woorde, net woorde - of is daar 'n ander dimensie, 'n dieper geheim agter, of binne, die woordoppervlak? Die vraag is: Hoe moet die stroom van woorde vloei; hoe moet die woorde gebundel word om werklik 'n préék te vorm? Wat maak ons preke wérklik Woordryk? ${ }^{4}$

\section{3. 'n Definisie van die prediking: een-stemmigheid op die kansel}

Anders gestel: Wat ís 'n preek? En: maak dit nog sin om te preek? Wat is die geheim daarvan? Daar bestaan geen resep nie. Wie "geheim" in die opskrif van hoofstuk 2 as "vinnige oplossing" verstaan het, het dit verkeerd gelees. Daar ís nie iets soos 'n retoriese tienpuntplan wat ons almal met 'n towerslag (oornag - meestal Saterdagnag!) in preekmeesters kan omskep nie. Daarom bied ek dit wat in hierdie boek volg ook met huiwering aan, met die wete dat dit voorlopig en fragmentaries is, terwyl die woorde van Augustinus oor die prediking net so wel van hierdie perspektief op die prediking geld:

4 Dis natuurlik geen nuwe vraag nie. Oor die verhouding tussen die Woord van God en die baie woorde van die prediking is daar al boekdele geskryf. Ten diepste gaan dit oor die vraag: Wat is die verhouding tussen openbaring en eksistensie, en wat is die homiletiese implikasies daarvan? 'n Klassieke voorbeeld hiervan is die kritiek wat soms op die homiletiek van Karl Barth uitgespreek word, naamlik dat hy só 'n klem op 'n "Woordteologie" sou plaas, dat daar geen ruimte vir die menslike subjek oorbly nie - 'n kritiek wat na my mening nie sondermeer waar is nie (vgl. verder punt 2. 3; ook Daiber 1983: 93, en Josuttis: 1973: 22-43). 
"En ek... wat dit op my geneem het om met julle te praat, dink julle daaraan wie ek is, en wat ek op my geneem het. Want ek het dit op my geneem om Goddelike dinge te verkondig - en ek is 'n mens; geestelike dinge - en ek is vleeslik; ewige dinge - en ek is sterflik... Na my maat ontvang ek wat ek aan julle bedien. Wanneer geopen word, wei ek saam met julle; wanneer die deur gesluit is, klop ek saam met julle." (Vgl. Van Oort 1991:8; ook 1989:85)

In die prediking gaan, soos ek reeds gesê het, 'n verskeidenheid aktiwiteite deur die tregter van die verkondiging. 'n Mens sou ook kon sê: in die prediking vind daar, bewus of onbewus, 'n "vermenging" van ten minste vier soorte tale of grammatikas plaas, vloei dit saam in die woordstroom, naamlik die stem van die prediker, van die Bybelteks, van die gemeente (konteks) en van God. Die baie woorde waarvan Mark Twain gepraat het, sou op 'n empiries-linguistiese vlak gesien, breedweg in hierdie vier kategorieë geplaas kon word. Dis immers 'n prediker wie se stem op die kansel opklink, 'n stem waardeur die persoon van die prediker bewus of onbewus voorgestel word. Daar word tog uit 'n Bybelse teks aangehaal, of gedagteinhoude daarvan weergegee, sodat die stem van die teks hoorbaar mag word. Daar is - hopelik - 'n wisselwerking tussen prediker en gemeente, wat veronderstel dat die prediker in die preekmaakproses na die stem van die gemeente geluister het. En daar word normaalweg gepreek met die veronderstelling of geloof dat God self op een of ander manier in dit alles ter sprake sal kom, en dat sy stem hoorbaar sal word. Die geheim van die prediking het na my wete veel te make met die manier waarop bierdie woordkategorieë met mekaar in verband staan en teologies geïtegreer word, met die wyse waarop hierdie stemme mekaar vind om akkoord te gaan, en een-stemmig te wees. Dat dít egter nie 'n maklik oplosbare geheim is nie, sal enige ervare prediker kan getuig!

Daar is ' $n$ hele aantal homilete wat aanvaar dat bogenoemde vier faktore wesenlik vir die preekmaakproses is. Van der Geest (1981:62) en Wardlaw (1988:64) konsentreer meer op die drie uiterlike konstituente, naamlik prediker, teks en gemeente, maar gaan tog van die veronderstelling uit dat God op een of ander wyse deur sy Gees in die prediking ter sprake (moet) kom. Ander, soos Patte (1984:21 e. v.), Craddock (1985: 22 e. v.), Bailey (1991:60) en Bohren (1971:547 e. v.) gebruik die vier elemente eksplisiet in hulle homiletiese refleksie - laasgenoemde veral ook as hy 'n raamwerk vir die preekanalitiese metode voorstel.

Dis interessant om daarop te let dat ook die preekdefinisie van Karl Barth - reeds in 1961 geformuleer - iets van hierdie vier komponente bevat, en dat Barth dus nie, soos dikwels beweer word, geen ruimte gelaat het vir die menslike element met sy beklemtoning van die openbaringskarakter van die prediking nie. Die opmerklike leser sal bogenoem- 
de vier "pilare van die prediking" sonder veel moeite in die volgende kan herken:

1. Preaching is the Word of God which he himself has spoken; but God makes use, according to bis good pleasure, of the ministry of a man who speaks to his fellow men, in God's name, by means of a passage from Scripture. Such a man fulfils the vocation to which the Church has called him and, through his ministry, the Church is obedient to the mission entrusted to ber.

2. Preaching follows from the command given to the Church to serve the Word of God by means of a man called to this task. It is this man's duty to proclaim to his fellow men what God himself has to say to them, by explaining, in bis own words, a passage from Scripture which concerns them personally (1964:65).

Daar word algemeen aanvaar dat daar'n sinvolle en teologies-verantwoorde samehang tussen die vier komponente gevind moet word. Maar hoe? Hoe weet ons of, en wanneer, die konvergensie plaasgevind het? Wat bepaal die punt of oomblik van fusie? Hieroor drie opmerkings:

\subsubsection{EEN-STEMMIGHEID AS GAWE VAN DIE GEES}

Is dit iets wat jy hoegenaamd kán of móét analiseer? Is dit nie eerder iets wat jy maar net as gawe kan ervaar, en daarom verwag nie? D. Martyn Lloyd-Jones skryf byvoorbeeld - uit evangelikale hoek - in dié trant oor die werking van die Gees in die prediking: "How do we recognize this when it happens? Let me try to answer. The first indication is in the preacher's own consciousness... You cannot be filled with the Spirit without knowing it... How does one know it? It gives clarity of thought, clarity of speech, ease of utterance, a great sense of authority and confidence as you are preaching, an awareness of a power not your own thrilling through the whole of your being, and an indescribable sense of joy... What about the people? They sense it at once; they can tell the difference immediately. They are gripped, they become serious, they are convicted, they are moved, they are humbled... What then are we to do about this? There is only one obvious conclusion. Seek Him! Seek Him!... But go beyond seeking Him; expect Him." (1976: 324-325)

Sonder twyfel lê die geheim van die prediking in die werking van die Gees. Die geheim van die prediking - die teologiese integrasie van die stemme - is ten diepste 'n pneumatologiese geheim. Die stem van die prediker, van die teks en die gemeente word deur die Gees saamgesnoer om stem van God te wees. Dit ís so. Maar, hoewel hierdie geloofsbelydenis waar is en net maar beaam kan word, help dit ons metodologies gesproke nie veel verder nie. Kan ons iets meer doen as soek en verwag? Of anders, 
meer positief gestel: is dit nie juis die pneumatologie wat aan ons die vryheid skenk om hierdie soeke en verwagting metodologies in te kleur nie? Gees en metode mag tog nooit teenoor mekaar te staan kom nie (Bohren 1971: 76 e. v.; vgl. ook verder hoofstuk 6).

\subsubsection{TEEN-STEMMIGHEID AS TEOLOGIESE DISINTEGRASIE}

Of, dalk kom ons 'n ent nader aan die geheim van die integrasie van die stemme, as ons let op die teenpool - waarvan daar oorgenoeg voorbeelde is! Moontlik kom die integrasie juis helderder in die lig wanneer ons die verskynsel van disintegrasie onder die vergrootglas plaas. Want, wanneer hierdie verhouding, hierdie integrasie na een of ander kant skeefgetrek word, ly die prediking daaronder skade, word dit trouens in sy wese aangetas - en kan dit preekanalities aangetoon word ${ }^{5}$. Breedweg gesproke kan dit byvoorbeeld gebeur

- as die prediker sy of haar eie stem (of geselekteerde teologiese temas) liefhet bo enigiets anders. Dan smoor die prediker se stem die ander stemme in die preek, en word dit 'n alleenspraak.

- as die preek bloot uit "korrekte eksegese" van die Bybelteks bestaan. Dan word dit onmenslik, sonder die vlees-en-bloed-getuienis van die prediker en die konteks van die gemeente - dikwels onder die illusie dat dit "net die Bybel is" wat ons verkondig.

- as die stem van die gemeente, oftewel konteks, alle ander stemme oordonder. Op die oog af kan sulke preke aktueel klink, maar die uiteinde is dat die evangelie-vir-die-tyd verlore gaan.

- as die prediker "die stem van God' voorhou asof dit loodreg uit die hemel na ons toe kom, sonder enige menslike of kontekstuele verpakking. Die gevaar is dikwels dat sulke predikers geen teenspraak of teenstem duld nie, dat hulle nie leerbaar is nie, en trouens dikwels hulle eie bedieningsonbevoegdhede agter 'n waas van goddelikheid wil verberg.

\subsubsection{DIE STEM AS DINAMIESE FENOMEEN}

Oor die disintegrasie van die stemme kan ons dus preekanalitiese opmerkings maak. Die teen-stemmigheid, oftewel homiletiese polifonie (en soms kakofonie) is op bepaalde punte aanwysbaar. Kan ons daaruit positiewe en inhoudelike afleidings maak vir 'n preekmaakproses waarin die stemme

5 Voorbeelde van sulke preekanalises kan gevind word in die volgende boeke oor die prediking: God vir ons (1994); Die uitwissing van God op die kansel (1996); Die uitwysing van God op die kansel (1998) en Die genade van gehoorsaambeid (2000). 
kongruent is? Eers 'n algemene opmerking: oor elkeen van hierdie stemme sou daar uiteraard homiletiese boekdele geskryf kon word. In die hoofstukke wat hierop volg, staan ek breevoeriger by elkeen daarvan stil:

- Hoofstuk 3: Die lewende stem van die evangelie: wanneer die teenwoordige God praat

- Hoofstuk 4: Die lewende stem van die evangelie: wanneer die Skrif praat

- Hoofstuk 5: Die lewende stem van die evangelie: wanneer die gemeente praat

- Hoofstuk 6: Die lewende stem van die evangelie: wanneer die prediker praat

Hopelik sal 'n beter begrip van die onderskeie rolle en funksies van die stemme reeds die teologiese integrasie daarvan dien. Ek neem die leser egter aan die einde van elke hoofstuk ook op 'n preekanalitiese toer, juis om op die teologiese disintegrasie van die stemme te wys. Elke hoofstuk word afgesluit met 'n preekvoorbeeld, wat onderskeidelik die funksies van die vier stemme (van God, die teks, die gemeente en prediker) illustreer.

Hoe moet ons die verhouding tussen hierdie vier stemme verstaan? Kom ek makk voorlopig die gordyn op die geheim hiervan op 'n skrefie oop. Hopelik lok dit die leser verder in. Hopelik gee dié aptytwekker smaak vir dít wat kom!

Met die teologiese integrasie van die stemme bedoel ek nie dat hulle min of meer in balans gebring moet word, of dat hulle noodwendig altyd dieselfde gewig moet dra nie. Die samesmelting van stemme is nie soos 'n chemiese vermenging waarin die bestanddele in presiese gelyke mate of gewigte ingevoeg word nie. Die stemme is nie dooie stowwe nie, maar'n lewende fenomeen, wat onderlinge verhoudings veronderstel.

Ek het 'n doelbewuste keuse gedoen vir die begrip stem, 'n konsep wat na my mening nog nie genoegsaam vir die homiletiek ontgin is nie. Rondom die woord stem ontspring 'n wye semantiese veld, met begrippe soos: instemming, eenstemmigheid, stemreg, stemloos, buite stemming bly, om stemming te skep, stemmingsvol, stemmig, ens. - almal begrippe wat benadruk dat die stem 'n lewende fenomeen is. Dis meer as woorde of begrippe op papier. 'n Stem bevat iets persoonliks; in die stem word die identiteit van die persoon wat praat, uitgedruk (vgl. Möller 1996:33-36). Trouens, 'n mens sou selfs kon sê dat as jy nie die stem van die ander hoor nie, daar normaalweg nie 'n ware ontmoeting met die persoon kan plaasvind nie. ${ }^{6}$ Om byvoorbeeld 'n

6 Dit sluit natuurlik nie dowe mense van ware kommunikasie uit nie. Die reel is egter dat die komponent van audio een van die basiese vertrekpunte in normale menslike kommunikasie uitmaak. 
brief te lees, is nie dieselfde as om 'n lewende ontmoeting met iemand deur die hoor van sy of haar stem te hê nie.

In terme van die prediking beteken dit: die prediker se stem bemiddel iets van sy of haar persoonlikheid, en hopelik van die ontmoeting wat hy of sy as persoon met God gehad het. Dit verklank dus iets van die feit dat die prediker die stem van God gehoor het, deurdat hy of sy iets van God se Persoon ervaar het. Maar, waar hoor die prediker die stem van God? In die Bybelteks. Maar om die stem van God in die Bybelteks te hoor, beteken meer as om net eksegetiese of historiese of linguistiese informasie daaruit te kry. Die bedoeling van die Bybelteks is om God se lewende stem te verwoord, en so tot 'n ontmoeting met Hom as Persoon te lei. Luther noem hierdie stem van God in die Bybelteks die viva vox evangelii, die lewende stem van die evangelie (vgl. Meuser 1983:55). Hierdie stem moet jou as prediker, as persoon, in 'n dinamiese, lewende ontmoeting aanspreek, só, dat jy as prediker self nou 'n stem verkry om te praat. Die Bybelteks is die lewende stem van God wat op Skrif gestel is, 'n stem wat in 'n historiese situasie, in die tweegesprek tussen God en sy mense, opgeklink het. Hierdie lewende stem moet as ' $t$ ware telkens herontdek word, telkens weer by in-gestem word (vgl. Van der Velden 1989:126). Daarom mag die eksegetiese, historiese en linguistiese arbeid aan die teks nooit 'n doel in sigself word nie, maar eerder 'n manier waarop jy jou ore dig teen die teks hou, totdat die lewende stem wat in die Skrifte verborge is, opnuut gehoor word, en God so ontmoet word. Prediking is, met eerbied gesê, om soos

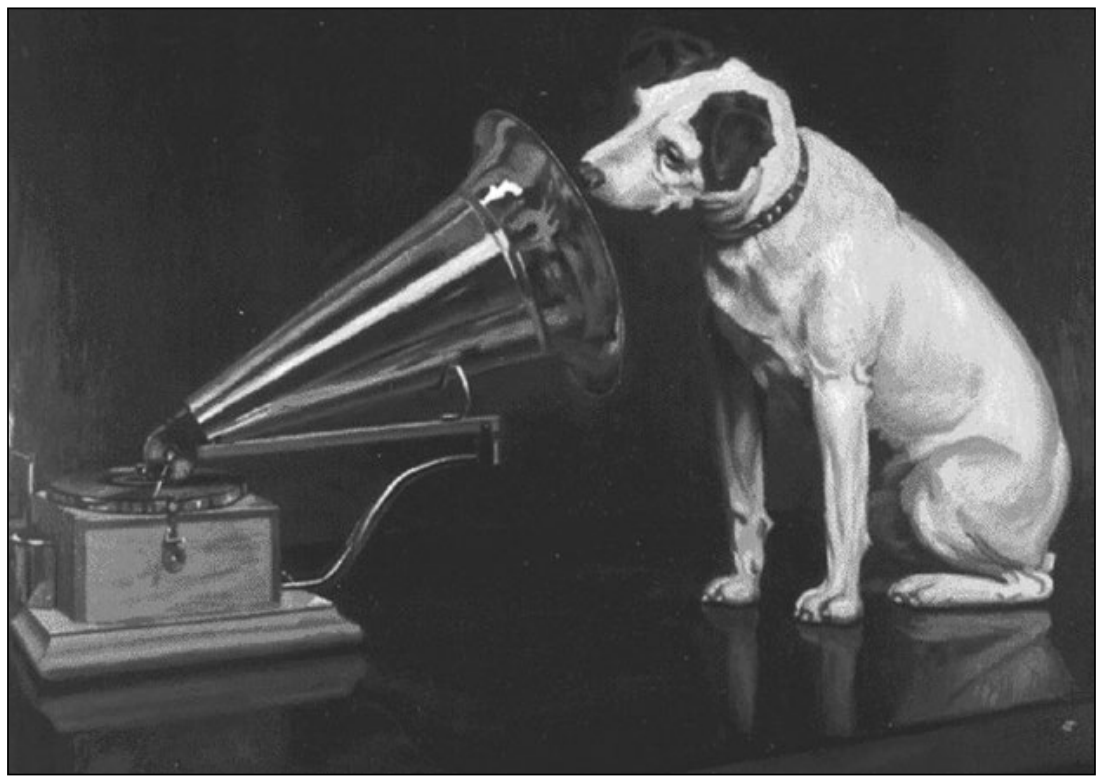


die hond in die ou advertensie skeefoor na die grammofoon te luister, totdat jy "His Master's voice" hoor. Deur die kraakgeluide van die historiese afstande heen, herken jy die stem van die lewende Meester. Kortom, geen prediker mag preek sonder só 'n ontmoeting met God in die teks nie (Iwand 1964:19). Geen prediker word mondig sonder om die woorde wat lewe gee, uit God se mond te hoor nie.

Maar die gemeente het ook 'n (unieke) stem. Die prediker moet leer om werklik aandagtig na hierdie stem te luister. Om bloot'n aantal statistiese gegewens oor 'n gemeente te versamel, is nie dieselfde as om die lewende stem van die gemeente in haar spesifieke konteks te hoor opklink nie. Inderdaad, te veel predikers hoor nooit die spesifieke stem van die gemeente nie, en praat dus te vinnig met pasklare antwoorde by die gemeente verby. Daar vind geen resonansie, geen samevoeging van stemme plaas nie, omdat daar nooit 'n lewende ontmoeting was nie. Maar, as daar nie so 'n ontmoeting tussen prediker en gemeente plaasvind nie, word die eenstemmigheid verder verbreek: die prediker kan dan ook nie die stem van die teks as die stem van God aan die gemeente verklank nie.

Want hieroor gaan dit tog in die samevoeging van ál die stemme: dat God se stem gehoor sal word. Hierdie "laaste" stem is nie die minste nie, maar die drakrag, die integrasiepunt van al die ander stemme. Daarom begin ek dan ook die hoofstukke wat volg, met hierdie stem - om iets uit te druk van die primêre funksie daarvan. Hierdie stem gee aan die prediker, die teks en die gemeente stem-reg. Sonder hierdie stem is die prediking stem-loos.

Of dalk net goeie teater. Athol Fugard het onlangs tydens 'n gesprek met Dali Tambo 7 daarop gewys dat 'n teaterstuk 'n "life-changing experience" kan word as daar drie komponente teenwoordig is, en as daar 'n gelukkige sinergie tussen hierdie komponente kan plaasvind: die boodskap van die teks ("script"), die passie van die speler(s) en die bereidwilligheid van die gehoor om hulle hierin te laat meevoer. Dit ís so - sover dit teater betref. In die prediking gaan dit egter oor meer, kom 'n vierdie faktor by wat die prediking juis uniek maak, naamlik die geheimenis van die stem van God.

Om te preek, is om meer as net informasie oor God aan ander oor te dra; dis die performasie van God se stem, deur die historiese afstande, die newels van onbegrip en die doofheid van die ore heen. Ja, wie ore bet en kan hoor, moet luister (Luk. 8:8)! 'n Preek is veel meer as die oordra van religieuse informasie, ook veel meer as woorde op 'n geskrewe manuskrip. Dis eerder 'n woord - en Woordgebeure, 'n stemgeklank, eenmalig en uniek. Preke kan in werklikheid nie herhaal word nie, nie oor-gepreek word nie. Want God se stem is

7 Tydens 'n onderhoud op die televisieprogram People of the South, 30 September 2001. 
nie staties nie, nie gefikseer in tyd en plek nie, maar histories, kontingent, lewend en verlossend. Preke is meer as begrippe of waarhede op papier, hoe eksegeties of dogmaties korrek ook al, maar eerder 'n woord wat tot stem wil kom, en so die stemming van die Koninkryk van God wil skep.

Hand aan hand met die begrip stem gaan dus ook die begrip hoor of luister. Predikers is mense wat kan luister, wat die ore by die regte bronne oophou, wat tussen die kakofonie van stemme die regte stemme hoor, en kan onderskei waarop dit regtig aankom. Mense wat die oor as 't ware dig teen die grond hou, teen die Bybelse teks wat as kanon aan aan ons gegee is, maar ook teen die hartklop van die gemeente en inderdaad ook die hartklop van die wêreld buite die gemeente, dig teen die hartklop van die gemarginaliseerdes, die weeskinders en die weduwees, die armes, die siekes, die hongeriges en dorstiges, diegene wat in die tronk en in die ellende is, want daar word die hartklop van God self op 'n besonderse wyse gehoor (vgl. Matt. 25:31-46; ook verder hoofstuk 3). En, terwyl die oor na onder gehou word, moet die eie hartklop van die prediker ook gehoor en verstaan word, en in pas met die hartklop van God gebring word. Daarom, terwyl die een oor op die grond gehou word, moet die ander oor ook altyd na bo wys, om die stem van die Gees te onderskei, en inderdaad die evangelie te hoor, om die stemme wat van onder af opklink (uit die teks, gemeente, wêreld en hart van die prediker self) as evangelie te onderskei en te hoor.

Miskien sou ek in die lig van dit alles 'n soort definisie van die prediking kon waag: Prediking vind plaas wanneer die stem van God deur die stem van die teks in die stem van die tyd (gemeentekonteks) deur die (unieke) stem van die prediker gehoor word. Wanneer hierdie vier stemme een-stemmig word, is die prediking inderdaad viva vox evangelii.

By die waagstuk van hierdie "definisie" voeg ek die verdere waagstuk van 'n skematiese voorstelling:

\section{DIE STEM VAN GOD}

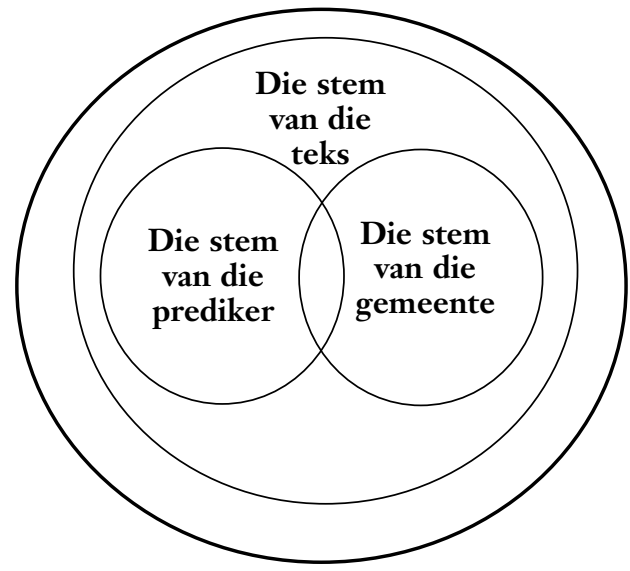


In hierdie skema is daar inderdaad sprake van 'n wisselwerking, 'n relasie, maar ook van prioriteite. God se stem voer die wisselwerking aan. As lewende God neem Hy die inisiatief en praat Hy deur die teks. Maar dié spreke geskied ook nie sonder die dialoog tussen prediker, teks en gemeente, en uiteindelik die dialoog met Hóm nie.

\subsection{Prediking as spel}

Kom ons verander vir 'n oomblik van rat. Ek sou die dinamika van die verhouding tussen hierdie vier stemme ook anders wou beskryf, naamlik as spel (ek kom breedvoeriger hierop terug in hoofstuk 6) Prediking het, na my mening, veel met kreatiwiteit en spel, verbeelding en kuns te make. Prediking is - as komponent van Praktiese Teologie - 'n estetiese handeling (vgl. Bohren: 1975: 90 e.v; Louw: 2001: 91 e.v; Cilliers 1998: 31-50; 1994a: 583-588)

Ek gebruik doelbewus die term spel. Dit is nie iets nuuts in die teologie nie - in die Skrif hoor ons al dat die wysheid soos 'n kind voor die Vader op die vooraand van die skepping gespeel het (Spr. 8:30). Uiteenlopende denkers soos Hieronymus, Origines, Gregorius van Nissa, Maximus en ander mistieke denkers verteenwoordig 'n teologie wat as teenstroom tot die offisiële onto-teologiese tradisie beskou sou kon word, en wat as dikwels miskende bewegings die mens as bomo ludens wou herwin, 'n spelende mens wat mede-skeppend aan die Koninkryk werk, saam met die spelende God (deus ludens).

Die diepste motivering vir die metafoor van spel lê inderdaad in die feit dat God self die spelende Een is. Dit blyk duidelik uit sy skeppende én herskeppende handelinge. God het die wêreld geskep vir sy eie genot, en ons hoogste doel as geskapenes is dan ook: om God te verheerlik en Hom vir ewig te geniet (Kategismus van Westminster, 1647). Ons lewens handel minder oor "sukses" as oor die oneindige vryheid wat ons het om mee te doen aan die oneindige vreugde van die Skepper - Goddank, ook in die prediking! Die koms van Christus versterk die beeld van die spelende God. Sy verlossingswerk is nie bloot 'n noodmaatreël om die ou spel van die skepping te herstel nie, maar om 'n nuwe spel te skep. Jesus het gely, sodat ons weer kan lag. Sy kruis - wat geen grap was nie - maak 'n nuwe spel, 'n verdiepte genot met God moontlik. By die kruis lyk dit of alle vreugde verdwyn, maar: "Easter is an altogether different matter. Here indeed begins the laughing of the redeemed, the dancing of the liberated and the creative game of new, concrete concomitants of the liberty which has been opened for us, even if we still live under conditions with little cause for rejoicing." (Moltmann 1971:50) 
$\mathrm{Al}$ spelende leer ons ook om die inkongruensies van die lewe te hanteer (vgl. Theron 1996: 212; ook sy uitgebreide literatuur oor die teologie van bumor). Trouens, die Christelike spel is gewortel in die geloof in die gróót inkongruensie: Christus, die Gekruisigde, is die Koning. Ons is waarskynlik gans te ernstig, te verbete op soek na die waarheid. Ons onvermoë om te speel, dui op ons ongeloof in die werking van die Gees. Ons vertrou Hom nie om nuwe, ongekende geheimenisse aan ons te openbaar nie. Ons is spelbrekers - teen die bedoeling van die spelende God in. Daarom is ons preke waarskynlik ook so vervelig.

\subsubsection{BUITELYNE VAN DIE SPEELVELD}

Om te preek, is om te speel. Bohren praat van 'n heilige spel, 'n spel met moontlikhede, met woorde, met die Woord, met die gemeente, met die lewe, met ervarings, met geleenthede, kortom, met alles wat oor die pad van die prediker kom. Wie hom of haar van hierdie preekspel wil onttrek, is 'n homiletiese nar (1971:372). Om te speel, het jy egter 'n speelveld nodig. Die ruimte waarbinne die prediker met 'n variasie van moontlikhede mag speel, is na my mening juis die vier basiese konstituente ${ }^{8}$ van die homiletiese proses wat ons tot dusver beskryf het, naamlik die Bybelse teks, die prediker, die gemeente en die Een wat verkondig word: die lewende, spelende God. Hierdie speelruimte is nie beperkend nie, en mag ook nooit in ons metodologie tot aparte en rigiede hokkies verword nie. Dis alleen in die wisselwerking, in die spel, ja die interspel tussen hierdie vier "bakens" of "vlagpale" dat die asemrowende rykdomme van die evangelie gesien, en die polifoniese stem van die Gees gehoor kan word (vgl. Bohren 1971:79).

- Die eerste vlag wat ons kan sien wapper, is inderdaad... God. Hiermee bedoel ek nie, soos ek reeds aangedui het, dat God slegs één faktor naas ander faktore is nie, maar eerder dat Hy die grondliggende, of omsluitende bron van die spel is. God is die Creator by uitstek, die kreatiewe Een, die deus ludens, wat ons uitnooi om saam met Hom kreatief te word, spelend op die spoor van 'n rykdom van perspektiewe. Daarom roep ons ook om sy Gees: Veni Creator Spiritus - 'n Gees wat werksaam

$8 \mathrm{Ek}$ is oortuig daarvan dat geen homiletiek of teologie sonder sekere "norme" of "bakens" of "waarhede" kan funksioneer nie. Daar ís iets soos 'n "minimally articulated narrative of faith - a minimally dogmatic statement of what the specific contents of anybody's worldview need to be." (Anderson 1995:204) Ek sien hierdie dogmatiese raamwerk egter nie minimalisties nie, maar uit 'n perspektief van verryking en geleentheid - waarin die maksimum kreatiwiteit te vinde is. 
is in die Bybelse teks, in die gemeente, in die prediker. ${ }^{9}$ Die Gees is die Een wat die spel laat vloei, wat ons telkens weer uit ons homiletiese hoekies en hokkies kom haal. Wat ons keer op keer bevry van ons neiging om die spel te laat stol. Of verbete aan één hoekpaal vas te klem terwyl die speelveld óóp lê, en die spel wink. Daar ìs inderdaad baie spelbrekers. Of dit nou die fundamentalisme is met sy stereotiepe siening van die Bybelse teks en waarheid, of die verbeeldinglose kontekstualisme van die postmodernisme met sy koerslose gerondslinger in 'n labirint (vgl. hoofstuk 6) - die Gees bly die Een wat telkens weer spel skep, weer verbeelding opwek, weer her-verbeelding moontlik maak van dít wat ons gemeen het uitgeklaarde waarhede is. Dis die Gees wat telkens weer nuwe ruimte, nuwe inspirasie, nuwe perspektiewe skep, wat ons deurstuur tussen die Skilla van fundamentalisme en die Charibdus van kontekstualisme, dwarsdeur die homiletiese engtes waarin ons so maklik verval. En Hy lei ons altyd tussen die bakens, die ligtorings, die wapperende vlae wat Hy sélf daar gestel het (vir 'n uitgebreide bespreking, vgl. verder hoofstuk 3).

- Die tweede vlag wat ons sien wapper, is die Bybelse teks. Hierdie teks bied byvoorbeeld nié - soos die modernisme ons vir dekades lank wou laat glo - één, ewige waarheid nie, maar 'n multidimensionele tafereel van moontlikhede. Dit laat ons telkens vanuit'n ander hoek - byna soos Picasso se skilderye met sy baie gesigte - iets van die gesig van God sien, maar dis net iets, net één kant van sy gesig, net één van sy vele gesigte. Bybelse tekste bevat nie net een kernwaarheid wat deur historiese en linguistiese en eksegetiese metodes ${ }^{10}$ soos met 'n tang uitgetrek moet word nie, maar 'n speelse verskeidenheid, almal asemrowend genoeg om jou gedagtes en gebede verreweg te oortref (vgl. Efes. 3:20). Bybelse tekste open nuwe wêrelde, nooi ons in om saam met die lesers van alle eeue en oorde die variasie van God se handelinge te kom vier, en om die kans te hê om deur vreugde verras te word. Bybelse tekste

9 Dis opvallend dat Bohren sy Praktische Theologie als theologische Ästhetik (1975:35 e.v.) eksplisiet binne die horison van die pneumatologie wil ontwikkel. Volgens hom is die Gees die Een wat vryheid in die metode skenk, wat aan die menslike en die maakbare 'n bepaalde waarde in die teonome resiprositeit tussen God en mens gee. Die Gees is per definisie die inkorporatiewe Een, wat 'n holistiese (trinitariese) blik op die teologie moontlik maak (67 e.v; vgl. ook Cilliers 1994b: 251-255; verder hoofstuk 6).

10 Die multidimensionaliteit van tekste vra ook dat ons voortdurend suspisieus oor ons eksegetiese en hermeneutiese metodes moet bly. Daarmee word nie gesê dat ons nie van 'n spesifieke metode gebruik moet maak nie - ons kán immers nie anders nie - maar dat ons dit bewustelik sal doen, wetende dat elke metode met sekere voorveronderstellings werk. Die punt is: daar moet daarteen gewaak word dat ons metodologie die multidimensionaliteit van die Skrif by voorbaat kortwiek (vgl. Deist 1988:53). 
mág daarom nooit platgestryk word om by óns verskraalde (premoderne, moderne, postmoderne) wêreldbeeld ingepas te word nie. Wie die Bybelse teks wil gladmaak (Brueggemann 1989:7: "reduced, trivialized and domesticated"), verstaan nie die aard daarvan nie, en misbruik dit uiteindelik in diens van een of ander ideologie. ${ }^{11}$ Teologie mag - op voetspoor van die teks - nooit 'n afgeronde, geslote sisteem raak nie. Om 'n teoloog te wees, is eerder om te dans, het Van Ruler al gesê (1969:16). Teologie is wesenlik disparaat. Dit leef van alternatiewe. In sinkretisme sit daar daarenteen altyd iets verstikkends. 'n Mens kan alleen asem haal, alleen maar speel voor en met God, as jy in die vars lug van teenstrydighede gebring word. Wie alle oneffenhede in die Bybelse teks en teologie wil afskuur, kan nie dans nie. Wie alles "tot 'n punt wil bring", kan nie lag nie. Wie alle misteries probeer oplos, alle teenstrydighede probeer rasionaliseer, uiteindelik die dwaasheid van die evangelie wil "opklaar", verstaan nie die spel van God nie. In al sulke pogings tot ontluistering sit die gees van die kettery (Van Ruler 1969: 39; vir die rol van die Bybelse teks, vgl. verder hoofstuk 4).

- Maar, stel hierdie verskeidenheid van perspektiewe nie weer alles op losse skroewe nie? Nee, nie noodwendig nie. Want 'n ander hoekvlag wat op die speelveld wapper, is die gemeente, en in besonder ook die ekumene. Preke behoort nie aan dominees nie, maar aan die communio sanctorum. Daarmee word nie net die gemeente in wydte bedoel nie, maar ook in diepte, die gemeente wat oor denominasies en ruimte en tyd strek. Die Gees is aan die kerk gegee, en dis in die gesprek met hierdie kerk dat die (spesifieke kant van) die waarheid vir hier en nou gevind word; dis in die ekklesiale diskoers (vgl. Cilliers 1992: 383-390) dat die besonderse gesig van God vir die besonderse situasie raakgesien word. Die punt is: predikers sal weer moet leer om na die stemme van die gemeente te luister, om krities te bly as daar net één, veral eksklusiewe stem opklink; om soekend en spelend jouself te relativeer, in die bede en hoop dat die waarheid van die evangelie in die baie stemme van die gemeente gehoor en gehoorsaam sal word. Augustinus het al gesê: as ons ophou om God te gebruik (as noodhulp, religieuse vuller, ens) en Hom as God geniet, word ons vry vir die genot in God en die genieting van mekaar in God (fruito Die et se invicem in Deo). Die

11 'n Goeie (slegte!) voorbeeld is die NG Kerk se Skrifgebruik tydens die apartheidsera. Tekste is by voorbaat gestereotipeer om die ideologie van nasionalisme te ondersteun. In preek op preek vind 'n mens - maak nie saak oor watter teks gepreek word nie - altyd dieselfde struktuur van skuldverplasing, analogie en moralisme (Vgl. Cilliers 1994c). Moralisme as sodanig is waarskynlik die bekendste vorm van stereotipering wat oor denominasionele grense heen voorkom (vgl. Cilliers 1996: 16 e.v.). 
spel, ook die homiletiese spel, is altyd 'n koinoniale spel (vgl. verder hieroor hoofstuk 5).

- Maar, daar is nóg 'n hoekvlag op die speelveld van die prediking, naamlik die prediker self. Predikers is nié bloedlose "kanale" wat die transendentale bloot moet "bemiddel" nie. Predikers is egter ook nie die sleutel wat letterlik alles in die prediking moet oop of toe sluit nie. Predikers is kreatiewe ménse wat aan die hand van 'n kreatiewe teks binne die ruimtes van 'n kreatiewe gemeenskap getuig van die kreatiewe God. Daarom word hulle gedurig gerelativeer én geïnspireer, moet hulle leer om die teenoorgesteldes van hulle sieninge te waardeer, om skynbare onversoenbares te laat ko-eksisteer, om te lag wanneer kontradiksies aan die orde van die dag is, en om nederig aan te hou met die spel, al beteken dit dat jy telkens van jóú siening en interpretatiewe mag gestroop en in jou homiletiese ego gewond of afgeblaas word. Om te preek, is om 'n poëet te wees, is om deel te neem aan die spel van poiesis, is om jou drang tot (kognitiewe) oorheersing op 'n kreatiewe wyse los te laat, en die sin nie net te soek nie, maar veral te vier. Poësie is immers die karnaval van moontlikhede, waar ander wêrelde en opsies verbeeldend oorweeg word. Dis inderdaad spel sonder (voortydige) sensuur, spel wat droom van 'n ander, veranderde wêreld, wat die wêreld al verbeeldend in 'n nuwe rigting droom en druk. Poëtiese prediking herinner ons daaraan dat geskiedenis nooit afgeloop is nie, dat situasies verander kán word. Dis altyd prediking van dit wat vir God moontlik is - al lyk dit nou nog na die onmoontlike (vgl. verder hoofstuk 6 vir die rol van die prediker).

In die volgende hoofstuk begin ons dan met die kreatiewe, spelende hoorproses van hierdie boek, deur in die eerste plek te luister na hoe die stem van God in die prediking gehoor kan word, só gehoor kan word dat ons ore ook oë word - oë wat God op 'n nuwe manier sien. 


\section{Die lewende stem van die evangelie: wanneer die teenwoordige God praat}

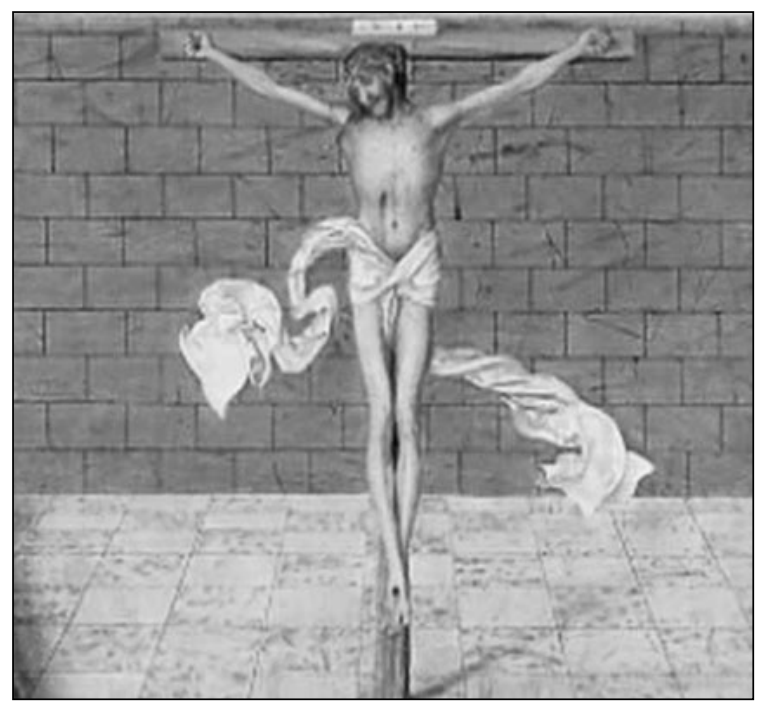

In hierdie hoofstuk let ons op

- Die onmisbare teenwoordigheid van God in die prediking en erediens, en hoe dit ons in beweging bring

- Die wonder dat die teenwoordige God aan die Woord kom en met ons praat

- Die goeie nuus dat hierdie spreke van God altyd evangelie, dit wil sê die verlossende handeling van God, is

- Die doelwit van alle prediking: dat hoor ook sien word, dit wil sê dat die teenwoordige God in die geloof waargeneem word, en

- Preekvoorbeelde van hoe hierdie evangelie van die teenwoordige en sprekende God in moralisme verander word 


\subsection{Inleiding: waarom gaan ons kerk toe?}

Waarom gaan ons kerk toe? Wat hoop ons om daar te beleef of te ontvang? Fjodor Dostojevski vertel aangrypend van een van sy eerste ervarings as kind in 'n erediens:

Nog voordat ek geleer het om te lees, nog voor my agste jaar, bet ek 'n geestelike ervaring gehad. My moeder het my eenkeer alleen (ek weet nie waar my broer dié keer was nie) op die Maandag van lydingsweek na die nagmaal gebring. Dit was 'n belder dag, en ek berinner my nog, asof ek dit nou voor my sien, hoe die wierook uit die wierookbak saggies opgestyg bet. Van bo af, deur die smal venster van die koepel bokant ons, bet die lig van God ingestroom, en die opstygende wierook het met die sonstrale vermeng. 'n Heilige ervaring bet deur my gegaan, en vir die eerste keer bet ek doelbewus die Woord van God in my ingeneem. ' $n$ Seun met 'n groot Boek het na die middel van die kerk gestap, en so groot was die Boek dat dit vir my gelyk het of by dit net met moeite kon dra. Hy bet dit op die kateder neergesit, dit oopgeslaan en begin lees, en skielik bet ek iets daarvan verstaan, en het ek vir die eerste keer in my lewe begryp dat daar in die kerk uit die Boek gelees word." (vry vertaal uit: Die Brïder Karamasoff 1959: 584)

Waarom gaan ons kerk toe? 'n Mens sou hierdie vraag sekerlik op baie maniere kon beantwoord. AA van Ruler het byvoorbeeld 'n boek geskryf (Waarom zou ik naar de kerk gaan?) waarin hy nie minder nie as 21 redes lys waarom dit inderdaad nog die moeite werd is om kerk toe te gaan. En dit terwyl daar tog ook baie redes sou kon wees om nié kerk toe te gaan nie! Trouens, sê Van Ruler, nie-kerkgangers sou waarskynlik 'n ánder titel aan sy boek wou gee, naamlik: Waarom ek nié na die kerk toe gaan nie... Want, redeneer hulle:

"Word ik daar beter van? Word ik er wijzer van? Krijg ik iets mee? Het beeft toch geen enkele zin? Wat ze in de kerk zeggen is toch sentimenteel gefemel? Het zegt me trouwens niets!... Eerlijk gezegd: in zo 'n kerkdienst is het een stom-vervelende boel!... De kerk boudt de mensen alleen maar dom! Dacht je nu werkelijk, dat ik al die sprookjes en mythen, die in de kerk worden opgedist, zou kunnen of ook maar zou willen geloven?... Bovendien: al die mensen, die daar in de kerk zitten, zijn mij ook veel te buichelachtig en te uitgestreken!" (1972:170)

Ensovoorts. Ja, dit ís inderdaad 'n wonderwerk dat so baie mense nog Sondag na Sondag in die kerk hulle opwagting maak. Daar is soveel aan- 
loklike alternatiewe. Kyk, die versoeking om ná 'n besige week of 'n laat Saterdagaand 'n bietjie langer in te dut, of die mooi weer van die Sondag te benut vir 'n potjie gholf of 'n paar ure se tuinwerk of sommer net om te ontspan oor 'n koppie koffie en die Sondagkoerant, is tog nie 'n illusie nie! Weeg dit nou op teen 'n tipiese uur in die kerk...?

En, ás mense nou 'n slag in die erediens kom, is dit dikwels vanweë twyfelagtige motiewe: uit gewoonte (en bygelowigheid), vanweë skuldgevoelens, of ouerdruk, of 'n vae gevoel dat 'n mens darem jou kinders "reg" moet grootmaak, ens. Uiteraard kom mense ook nog om ander, beter beweegredes in die kerk, naamlik: uit dankbaarheid, lojaliteit, 'n geloofsoortuiging, 'n toewyding aan die Here...

Waarom gaan mense kerk toe? Of: waarom behóórt hulle kerk toe te gaan? By al die baie antwoorde wat 'n mens kan gee - reg of verkeerd - is daar 'n dieperliggende antwoord, 'n antwoord wat nie alleen die wese van die erediens raak nie, maar ook die wese van ons bestaan. Dis as ' $t$ ware die "struktuur" agter al die ander strukture. Die kernstruktuur. Die wesenlike kenmerk van die erediens. Dis die diepste teologiese perspektief op al die strukture of onderdele of momente van die liturgie. Voordat jy aanpassings mak aan die liturgiese onderdele of ordes, moet jy eers iets van hierdie kernstruktuur verstaan, anders kan jou aanpassings niks anders wees nie as 'n oppervlakkige herrangskikking, 'n rondskuif van die stoele op die dek van die sinkende skip, wat jou onder die illusie kan bring dat jy grondig vernuwe het - terwyl jy die dieptepunt mis waaroor dit werklik gaan.

Waarvan praat ek? Dit kan op baie maniere verwoord word. Gereformeerdes noem hierdie kernmoment tereg: 'n ontmoeting met God. Dis wanneer ons wierook meng met God se lig, en die Boek hierdie ontmoeting aan ons verklaar. Wanneer jou onrustige hart sy rus vind in God (Augustinus). Wanneer jy die hoogste doel en sin van jou bestaan vind, naamlik om ingebring te word in die geheimenisse van Hom wat ons God noem. Vir die doel van hierdie boek noem ek dit: om bewus te word van die teenwoordigheid van die misterie van God, om te buig voor hierdie mysterium tremendum et fascinosum.

Dáárom kom ons kerk toe, of behoort ons te kom. Dáárna smag ons, bewus of onbewus. Dáároor handel dit in al die elemente van die liturgie en dus ook die prediking, of behoort dit te handel: om opnuut ingelei te word in die teenwoordigheid van die misterie van God, om Hom met verwondering te aanbid... as God. Daar is natuurlik ook ánder belangrike kernmomente in die erediens, byvoorbeeld dat ons die gemeenskap van die gelowiges beoefen, of dat ons die verlossing vier, of toegerus word vir ons taak in die wêreld, ens. Maar, as dit nie voortvloei uit hiérdie moment van misterie, hierdie wonder van ontmoeting nie, dan ís dit geen erediens nie. Trouens, wat sou erger kon wees as dít: dat God Hom uit ons eredienste 
onttrek, dat Hy vir ons sê wat Hy een keer vir die Israeliete gesê het (ná die episode met die goue kalf): Ek wil nie meer saam met julle trek nie (Eks. 32:1-6).

\subsection{God se teenwoordigheid bring ons in beweging}

Op God se teenwoordigheid kom álles aan. Maar, waaruit bestaan dit, en hoe herken jy dit? Wat is die tekens van sy teenwoordigheid? Ek maak huiwerend - drie opmerkings in dié verband. Dit hang saam met drie bewegings (en daar is vele ander!) wat na my mening plaasvind waar God teenwoordig is. Die eerste is:

\subsubsection{VAN FAMILIARITEIT NA GODSVREES}

Waar God teenwoordig is, verdwyn die (sondige) familiariteit. Want God is nié ons speelmaatjie nie. Wanneer mense hulle aanvoeling vir die misterie van God in die erediens verloor - soos na my mening tans opnuut gebeur - volg die liturgiese familiariteit as t' ware vanself. Dan vloei die elemente van die liturgie sommer gladweg van die een na die ander, vrolik en onnadenkend, so asof die erediens net maar nóg 'n item op ons weeklikse program is wat afgehandel moet word. Nêrens word ons tot swye geskok of tot (ware) verootmoediging gevoer of tot verwondering gelei nie - ons ploeter maar voort, besig met ons "God talk" en ons God-speletjies. Die erediens word só gelykgemaak met dit wat daarbuite gebeur, word só aangepas by dit wat mode is, dat jy nie mooi meer weet wat nou eintlik die verskil tussen kerk en konsert, tussen liturgie en televisie, tussen erediens en inkopies-doen is nie. Ons weet nie meer met Wie ons te doen het nie. Ons vergeet: geen mens kan God sien en bly lewe nie (Eks. 33:20). Hy alleen besit onsterflikheid; Hy woon in ontoeganklike lig (1 Tim. 6:16). Selfs wanneer Hy Homself openbaar, hul Hy Homself in donkerte (Psalm 18:11,12). Ons God is 'n verterende vuur (Heb. 12:29). Ja, wanneer ons in die erediens is, speel ons met vuur! 'n Mens dink aan die klassieke beeld van Annie Dillard:

Het enigiemand die vaagste benul watter soort krag ons so onnadenkend in die kerk tydens ons gebede inroep? Of is dit eerder so, soos ek vermoed, dat niemand 'n woord daarvan glo nie? Die kerke is soos kinders wat op die vloer met hulle chemiestelle speel, besig om 'n klomp TNT-plofstof te meng om die Sondag om te kry. Dit is gekheid om damestrooiboede of fluweelboede kerk toe te dra; ons behoort almal valbelms te dra. Die diakens behoort aan ons lewensgordels en seinfakkels uit te deel. Hulle beboort ons aan 
ons kerkbanke vas te gespe, want die slapende God mag dalk een dag wakker word en aanstoot neem, of die wakker God mag ons so ver in die diepsee uitwerp dat ons nooit weer kan terugkeer nie (vry vertaal uit: Teaching a stone to talk: expeditions and encounters).

Waarlik, wie iets van die woord "God" begin verstaan, storm nie sommer meer in waar die engele huiwer om te trap nie. Familiariteit maak plek vir vrees, ja, vir die vrese van die Here, vir Godsvrees. Dis 'n ander soort vrees as menslike vrees. Dis nie 'n negatiewe vrees nie, maar 'n positiewe, 'n eerbiedige erkentenis dat God Gód is. Dis om in eerbied vir en voor die Here te lewe gedurende die tyd van ons vreemdelingskap in die wêreld (1 Pet. 1:17). Dis 'n lewenshouding, en daarom ook 'n liturgiese styl wat dwarsdeur ons eredienste herken moet word: God is hier teenwoordig, laat ons biddend nader...

Die tweede beweging is:

\subsubsection{VAN FORMALISME NA VRYHEID}

Die korreksie op familiariteit is egter nou weer nie formalisme nie. Trouens, dis moeilik om te weet watter een van dié twee verskynsels die ergste is! God se teenwoordigheid word nie gewaarborg deur stokkerige korrektheid nie. Die verbete onderhouding van tradisie is geen tasbare teken van God se teenwoordigheid nie. Inteendeel! God is groter as tradisie, groter as historiese frases of eeue-oue liturgiese formules. Daar sit geen magiese of goddelike krag in die blote repetisie van liturgiese of dogmatiese juwele uit die verlede nie, waarmee ek geensins sê dat daar nie plek is daarvoor in die erediens, of dat dit selfs krities noodsaaklik is dat ons ons liturgies-historiese wortels moet waardeer en telkens weer moet opsoek nie. Natuurlik nie! Net maar: tradisie is geen God-outomaat nie. Trouens, formalisme kan 'n handige wegkruipplek word, 'n liturgiese skuiling teen die teenwoordigheid van God. Maar, God sien dwarsdeur ons (Psalm 139:1). Ook deur ons godsdienstigheid.

Die ironie is: jy kan formeel korrek wees, en tog allesbehalwe vry. Net waar die Gees van die Here is, is daar vryheid (2 Kor. 3:17). Wat is vryheid? Dis nie familiariteit nie. Vryheid is wel die vrymoedigheid om met vrees (eerbied) die Here te nader - omdat Hy ons láát nader. Vryheid is om God hartlik te loof, is om psalms onder mekaar te sing, lofgesange en ander geestelike liedere, is om met jou bele hart tot eer van die Here te sing (Efes. 5:19). Waar die Gees van die Here is, is vryheid, en waar vryheid is, moet God van harte geloof word. Dit kán nie anders nie.

Die derde beweging vind plaas. 


\subsubsection{VAN VERBRUIKERSMENTALITEIT NA VERWAGTING}

Die liturgie is God se werk én dis mense se werk - altyd in hierdie volgorde. Die liturgie is altyd eers God se diens aan ons, dit wil sê sy genadige toenadering tot ons, voordat ons Hom kan dien (vgl. die dubbele betekenis van die Duitse: Gottesdienst). God se inisiatief staan altyd voorop: Hy roep ons nader, Hy is by ons teenwoordig, en Hy verander ons. Sy teenwoordigheid kan, soos ons reeds gesê het, nie gemáák of liturgies gewaarborg of gemanipuleer word nie. God se teenwoordigheid is onmaakbaar, nie die "doen-dit-self" tegniek van 'n liturg nie. Die brandende doringbos (Eks. 3) is tog nie die gevolg van liturgiese choreografie - beplan en uitgevoer deur mense of engele - met die doel om die doringbos-erediens meer "Moses-vriendelik" te maak nie! Nee, God verskyn. Hy openbaar Homself. Hy kom in ons midde. Hy is daar - uit genade.

Die erediens pas dus nie in by ons konsumpsiementaliteit van: dit moet werk en dit moet vir my werk en ek láát dit vir my werk nie. Die erediens is uit ons hande uit. Dis in God se hande. En tog - en dit is die asemrowende - is dit ook weer in óns hande! Ons - mense - beplan eredienste en voer dit uit. Nie die engele nie. Die liturgie val nie uit die hemel nie. Die erediens is ook óns verantwoordelikheid. Daarom moet ons juis alles in ons vermoë doen om dit te láát werk! Moet ons in elk geval, sover ons kan, alle struikelblokke op weg na die belewenis van die teenwoordigheid van God uit die weg probeer ruim. Want hierdie ervaring, hierdie "atmosfeer" van God se teenwoordigheid kán so maklik versteur word.

Ek praat uit dure ondervinding. Ek was by geleentheid die liturg in 'n erediens waarin iets "anders" was, iets van die misterie, van die onbeskryflike, maar werklike teenwoordigheid van God. Daar was 'n liturgiese progressie, 'n ontplooiing, met 'n klimaks in die slotlied van die gemeente. Hierna moes die seën uitgespreek word - die gepaste afronding van en uitsending ná die erediens. Net toe die gemeente klaar gesing het, storm een van die diakens die kansel op, en stop 'n briefie in my hand - ek moet 'n afkondiging doen wat vergete gebly het. Op die briefie het iets gestaan ek kan die besonderhede nie meer onthou nie - van 'n filmvertoning wat deur die jeugaksie in die kerksaal aangebied sal word. Spesiale pryse vir laerskoolkinders. Springmielies en toffie-appels kan tydens pouse gekoop word. Terminator II. Arnold Schwazenegger - of is dit Sylvester Stallone? Skop, skiet en ... nou ja, jy weet wat.

Ek het geweier om die afkondiging te doen. Die jongmense se fondsinsamelingsveldtog is 'n gevoelige knou toegedien. Hulle is vandag nog kwaad vir my.

God se teenwoordigheid kan nie gemáák word nie, maar die ervaring daarvan kan wel deur slordige of ongelowige of onsensitiewe liturge versteur of 
verstop word. Ons kan 'n liturgiese styl van verwagting openbaar, of dit verongeluk. Twee eredienste kan byvoorbeeld in presies dieselfde volgorde verloop, met presies dieselfde inhoude, preek, liedere, ens - maar die een is dood, en die ander tintel van die verwagting van die teenwoordigheid van die Here. Waarin lê die verskil? Ek sê dit huiwerend, want dit kan so maklik liturgiesmoralisties misverstaan word: Moontlik ook in die styl van die liturg. Inhoudelik en formeel kan hy of sy presies dieselfde sê as 'n ander liturg, maar die manier waarop dit geskied, getuig van 'n sensitiwiteit vir 'n groter Werklikheid. Dan is álles anders: jou stemtoon, jou liggaamshouding, jou manierismes, die manier waarop jy staan, waarop jy sing - of dit nou 'n lied van verootmoediging of ' $n$ loflied is. Alles is anders. Want jy wéét jy is in Groot Geselskap.

My Switserse mentor, Rudolf Bohren, het my op 'n keer vertel van die dag toe hy en sy vrou aan die ontbyttafel gesit het, en sy by die venster uitgekyk en gesê het: "Rudolf, dit gaan rë̈n." Hy het hom nie veel hieraan gesteur nie, want hy sou binnekort in sy studeerkamer gaan sit en werk, en die moontlikheid of waarskynlikheid van reën het hom dus nie geraak nie. Ná 'n paar uur het die lug opgeklaar, en Bohren en sy vrou het besluit om, soos hulle dikwels gedoen het, 'n ent in die Odenwald te gaan stap. Hulle was so 'n uur van die huis af weg, toe die wolke wéér begin saampak, en die lug swaar geword het, swanger aan die komende reën. Frau Bohren het in die lug opgekyk, en presies dieselfde woorde van die oggend herhaal, naamlik: "Rudolf, dit gaan rë̈n." Dit was dieselfde woorde, sinskonstruksie, grammatika. En tog was dit ánders. Dit was woorde vol verwagting. Woorde wat Bohren en sy vrou geráák het.

In die erediens kan ons sê: "Die Here is hier teenwoordig." Of ons kan sê: "Die Here is hier teenwoordig." En tussen dié twee uitsprake kan daar - letterlik - 'n hemelbreë verskil wees. Die een is stomp, geslote, sonder enige ruimte vir die Een wat as teenwoordig aangekondig word, en die ander is oop, gestrek in die hoop en gebed dat die Een van Wie gepraat word, inderdaad dáár is. Die een is 'n afkondiging en die ander is ' $n$ gebed.

Hierdie liturgiese styl van verwagting is 'n "oop" styl, een waarin liturg en gemeente sensitief is vir die moment(e) waarin die Here se teenwoordigheid helderder na vore kom, oop vir die ruimtes in die liturgie wat op 'n besonderse wyse deur Hom gevul word, en waarin die fluisteringe van sy Gees gehoor kan word. Momente waarin ons oë soos dié van die Emmausgangers oopgaan, en ons Hom herken wat saam met ons op die (liturgiese) pad was, en ons harte warm word vanweë sy teenwoordigheid (Luk. 24:31,32). Ja, daar is oomblikke wanneer jou hart warm kan word in 'n erediens: dit kan tydens 'n lied wees, in 'n frase van die dominee se preek, in die belewenis van gemeenskaplikheid met ander gelowiges, by die breek van die nagmaalsbrood. Momente waarin jy net wéét: ons is nie alleen nie, en ook buitestaanders sou moes uitroep: "Waarlik, God is hier by julle!" (1 Kor. 14:25). 


\subsection{Eredienste is spannend!}

Uit wat ek tot dusver gesê het, is dit duidelik dat ons liturgie nie anders kán as om paradoksaal (dialekties) van aard te wees nie. Dis spannend in die ware sin van die woord! Ons kan nie familiêr met God wees nie, en tog is ons sy familie, tog kom ons tuis by Hom as sy kinders, en as broers en susters van mekaar. Ons moet Hom vrees as die Here, en tog leef ons uit die verwagting dat $\mathrm{Hy}$ in ons midde sal kom, en dat ons tot Hom as óns Here mag nader. Ons kan Hom nie vasvang in liturgiese formules nie, en tog het ons die roeping om ons eredienste te beplan, om woorde en musiek en belydenisse te gebruik om ons reaksie op sy teenwoordigheid uit te druk.

Aan die een kant is sy alsiende oog op ons gerig (soos die een wat 'n mens soms aan die bokant van ou, godsdienstige portrette gesien het), en dit maak jou bang, want God sien dwarsdeur my, sien ook my sonde raak; aan die ander kant maak dit jou bly, want jy weet Hy kom in barmhartigheid en genade na jou toe, Hy kom sit saam met jou in die erediens (soos versimboliseer deur die leë stoel wat in sommige gemeentes se liturgiese ruimte, veral rondom die nagmaalstafel staan). Hierin - dat God, die heilige, ook die genadige, teenwoordige is - lê die diepste wonder van die erediens.

Die lig van sy genade skyn af op, en meng met, die wierook van ons gebede.

Sy Boek sê so.

Maar, hier hou die wonder nie op nie. Want: die teenwoordige God práát ook nog met ons!

\subsection{Die geheim van die prediking: dat die teenwoordige God met ons praat}

\subsubsection{DIE "EINTLIKE BENOUDHEID VAN DIE BEDIENAAR VAN DIE WOORD"}

Kom ons vat bogenoemde anders saam: teologies gesproke verkondig ons nie tekste nie, maar 'n Persoon; is prediking nie slegs die uitleg van 'n aantal waarhede nie, eerder die uitroep van God se Naam (Bohren noem dit Namenrede, 1971:110). Meer as dit: die Benoemde is in die prediking self dáár! In hierdie teenwoordigheid van God lê die begin en die einde, ja, die diepste geheim van die prediking. In die prediking staan of val alles inderdaad met die Groot $E k$, met die Drie-enige $E k$ is...

Die roeping van predikers is om, aan die een kant, die realiteit van die werkende God, sy praesentia realis dei in die Woord, kerk, sakramente en 
wêreld uit te wys; aan die ander kant handel dit oor die inneem daarvan, die geloofswaarneming en - ervaring van hierdie realiteit, ja, oor die sien van God deur die gemeente (vgl. Cilliers:1998:31-56; vgl. ook verder 3.6). 'n Mens kan predikers baie dinge vergewe, maar nie dít nie: dat hulle nie iets van hierdie Gods-ervaring, iets van hierdie teologiese insig "bemiddel" nie. Maar, wie van ons kán dit bemiddel?

Predikers se Skrifbeskouing is mede-bepalend vir die wyse waarop hulle preek (vgl. hoofstuk 4). Dit ís so. Maar 'n verengde Skrifbeskouing sonder 'n geïntegreerde Godsbeskouing lei tot Bibliolatrie. Ons aanbid nie 'n Boek nie, maar God, die Lewende God van die Boek. Die stem van die teks is alleen heilsaam omdat dit die stem van God bemiddel, as viva vox evangelii. Ons is bedienaars, nie van die letter nie, maar van die Gees. Die letter maak dood, die Gees maak lewend (2 Kor. 3:6). In dié sin mag ons sê: as die Skrif praat, praat God (Augustinus). Of, in die woorde van Calvyn: In die Skrif hoor ons die stem van die Persoon van die sprekende God (Dei loquentis persona).

Die mees wesenlike vraag wat ons dus aan die prediking kán vra, is: Kom God self hierin ter sprake? Voer Hy self die Woord? Presies hierin lê die crux van die prediking: Om só oor God te praat, dat God self kan praat. Maar, hoe praat'n mens oor God? En, hoe praat Gód? Karl Barth het by geleentheid 'n reeks lesings vir predikante gelewer, en onder meer gesê:

"Ons is teoloë en moet daarom oor God praat. Ons is egter ook mense en kán as sodanig nie oor God praat nie. Ons moet albei bierdie dinge weetdat ons oor God moet praat en nie kan nie - en juis daarin aan God die eer gee. Dit is die eintlike benoudheid van die bedienaar van die Woord. Alle ander dinge is daarnaas kinderspel." (vry vertaal; 1924:158)

Ja, hoe praat 'n mens oor God, só, dat Hy sélf kan praat? Wat sê jy as jy "God" sê? Hierop is daar geen logiese antwoorde nie, net teologiese. Die prediking het te make met 'n misterie, 'n geheimenis wat openbaar gemaak word (vgl. Efes. 3:3; ook 6:19). Dis slegs moontlik deur gebed, pleitend by God, om brood, om 'n vis...

Die vyf opmerkings wat volg, word in dié lig eerder as uitroepe van verwondering en nie as verklarende oplossings bedoel nie. Die leser sal ook opmerk dat die vyf onderafdelings nie van mekaar geskei kan word nie, en in 'n sekere sin presies dieselfde saak telkens vanuit 'n ander hoek toelig:

\subsubsection{OM TE PREEK, IS OM TE SÊ WIE WAS, IS, EN SAL WEES}

God het Homself geopenbaar (epifanie), en God sal Homself openbaar (parousie). Maar tussen wat was en sal wees, ís Hy ook, en is Hy ook by ons 
al die dae tot die voleinding van die wêreld (Matt. 28:20). Predikers hoef hierdie heilsrealiteit nie te skep nie, net daarvan te getuig, dit uit te wys, in die hoop en verwagting dat God self die prediking sal gebruik om te bevestig dat Hy wat was, ook is en sal wees. Om te preek, is om meegeneem te word in die beweging van die heil, in die realiteit van die werksame God tussen epifanie en parousie, en dit as wáár te verklaar. (vgl. Barth 1964: 67-73).

Juis daarom kan ons Bybelse tekste nie net lees in terme van hulle herkoms, hulle geskiedenis nie. Historiese en literêre wetenskappe wat predikers nie help om ook die toekoms van hierdie Bybelse tekste te ontdek nie, is ' $n$ struikelblok vir die verkondiging van die evangelie. Bethel Müller skryf mooi: "Die eksegese moet dus nie alleen grammatikaal-histories die teks vanuit sy konteks belig nie, maar dit eskatologies vanuit sy totale en belofte-swangere geskiedenis-horison belig. Die teks het 'toekoms': die eksegese moet die aanspoelende lig van die toekoms, van die belofte in hierdie teks opvang en dit aan die mens midde-in sy bistoriese bedreiging voorbou." (1973: 126).

Ons arbeid aan die teks moet ons help om by die God-sin van die teks (Wilson 1995: 82 e.v.) te kom, by die ontdekking van die teenswoordige en toekomende realiteit van die Een wat was. Prediking van die God-sin, ja die God-werklikheid en God-werksaamheid soos dit in die teks verklank word, is prinsipieël anders as om God voor te hou as 'n blote metafoor of 'n vergelyking, of as een of ander abstrakte term soos waarheid en liefde, of as 'n retoriese tegniek om hoorders te manipuleer, of as 'n idee wat die gemeente moet verstaan, of as 'n linguistiese God wat alleen binne die huis van ons taal kan bestaan. Nee, God is die lewende God, die Een wat Homself openbaar in Jesus Christus, wat gister en vandag dieselfde is, en tot in ewigheid (Heb. 13:8).

\subsubsection{OM TE PREEK, IS OM JOU SKOENE UIT TE TREK}

Ons verkondig nie 'n formule soos $\mathrm{H}_{2} \mathrm{O}$ nie, maar die lewende Here, nie 'n resep of 'n skema of 'n teorie nie, maar soos ek reeds bo gesê het, die Persoon van die sprekende God. Wie 'n resepte-teologie wil beoefen, het moeite om 'n resepsie-teologie te verstaan, om ontvanklik te wees om telkens maar weer iets van die grootsheid en onbevatlikheid van die Misterie van God waar te neem en in te neem. Ons teologie en prediking is nie 'n vernuftige stuk steierwerk wat óns oprig om God regop te bring of te hou nie. God het nie steierwerke of resepte nodig om God te wees nie. God is God. Onbegryplik. Selfs in sy openbaring bly Hy steeds in donkerte gehul (vgl. Psalm 18:12!). God is God. Ewig. Dis juis wat ons as tydsgebonde mense soms so verkeerdelik kwaad vir en hartseer oor God kan maak: ons verstaan nie dat Hy sy tyd neem om sy wil te doen nie; ons begryp nie dat Hy 
Homself in die gang van 'n lang heilsgeskiedenis stap vir stap aan ons as die Getroue God openbaar nie.

Wie al iets van "die eintlike benoudheid van die bedienaar van die Woord" waarvan Barth gepraat het, ervaar het, naamlik om oor hierdie geheimenis van God te móét praat, maar dit as mens nie kán doen nie, weet dat jy nie moet instorm waar engele met ligte tred loop nie. Om te preek, is om jou plotseling langs ' $n$ brandende doringbos te bevind (Eks. 3 ). Dis hier waar ons die skoene van ons voete moet uittrek, en weet: ons betree heilige grond. Augustinus het volgens oorlewering by geleentheid vir twee uur lank oor die misterie van God gepreek. Aan die einde sou hy uitgeroep het: "En as julle meer oor Hom wil weet, vra Hom dan self!" Ons kán die misterie van God nie uit-praat, nie uit-klaar nie. Ons kan alleen maar oor Hom praat in gebed, met toe oë en oop hande. Ons is bedelaars, dit is waar! (Luther op sy sterfbed)

God is meer as 'n probleem, meer as 'n vraagstuk wat ons moet oplos. God is God. As God moet Hy aanbid word, en aanbiddend be-vra word. As ek "God" sê, spreek ek my vraag uit, die diepste vraag van my lewe: Wie is $\mathrm{U}, \mathrm{O}$ God, wat is $\mathrm{U}$ Naam, waar is $\mathrm{U}$ te vinde? Miskotte skryf aangrypend oor hierdie diepste vraag: "Daar staat de prediker en de mensen wachten op hem. Ontzaglijk ogenblik! om door de grond te zinken. Want hij mag geen lezing bouden, geen toespraak, geen verbaal. De mensen beffen met bun gelaat en met bun zwijgende aandacht, die zich strekt, bun Vráag op. De mensen zeggen - en zij bebben volkomen gelijk - : nu wij begrepen bebben, dat bier is een vergadering niet van mensen onderling, maar van Gód met ons, nu willen wij ook Gód horen spreken, gij zelf bebt de verwachting in ons gaande gemaakt en daarom balen wij nu onze diépste vraag voor de dag, de vraag, die we elders streng verborgen houden, boewel ze ons steeds kwelt: de vraag naar God, naar de levende God. Wee de prediker die de mensen zo hoort vragen de éne vraag. En ook weer: welgelukzalig de prediker die het zó hoort, want bij voelt de vreselijke en beerlijke druk van het onmogelijke, hij voelt dat bem maar één ding overblijft: gans instrument te worden, dreunend en troostend orgel, door God bespeeld." (1976:200).

Ja, as predikers kan ons nie anders nie as om saam met die gemeente voor die Misterie van God met ons diepste lewensvraag te kniel nie, in die hoop dat Hy Homself op grond van sy openbaring opnuut sal openbaar, en ons tot 'n nuwe aanbidding gevoer sal word. Inderdaad: Wie "God" sê, sê aanbidding.

\subsubsection{OM TE PREEK, IS OM JOU HANDE OP TE HEF}

Dit - om "God" aanbiddend te sê - vra 'n ander soort styl as 'n styl van absolute sekerheid en ongebrokenheid. Ons verkry nie beheer oor God 
met ons baie woorde oor God nie. God is groter as ons preke. Prediking is nie 'n kontrole oor en van die waarheid nie. Dis juis wat ons van nature wil doen: God kleiner maak as wat Hy is, Hom kontroleerbaar en hanteerbaar maak. O Halver begin een van sy preke met 'n aangrypende gedig wat hierdie neiging treffend illustreer:

Liewe gemeente,

julle wil hê dat ek elke Sondagoggend

'n klein, liewe Godjie op julle knië moet kom neersit

sodat julle so 'n bietjie perdjie-perdjie met Hom kan speel.

Maar as julle klaar gespeel is, sit julle Hom weer terug in my arms

en moet ek maar sien kom klaar wat ek met Hom moet doen

tot volgende Sondag.

en as ek Hom in die week gaan wys wat onder julle verkeerd is,

in die familie, in die samelewing, in die politiek,

totdat Hy siek word daarvan,

dan word julle kwaad vir my en sê:

jy moes Hom maar liewers net Sondag uitgehaal bet... (1970:13; vry vertaal)

Nee, God mag nooit, ook in die prediking, 'n troetelbare godjie-op-dieskoot word nie. Die Misterie is eenvoudig te groot om perdjie-perdjie mee te speel. Prediking is eerder verdieping in die Misterie, verwondering oor die Drie-eenheid. Dis verlies van kontrole. Wie weet hoe God gaan werk? Wie kan aan Hom voorskryf? (vgl. Rom. 11:33-36) Dis 'n oop styl, “openended" - oop in die rigting van God. 'n Styl waarin al jou homiletiese voorbereiding en teologiese geleerdheid op die altaar moet kom, waarin jou preek soos 'n Isak - jou enigste wat jy liefhet - telkens weer prysgegee moet word.

Ek herhaal: die grondvorm en dieptestruktuur van die prediking bly in dié sin een van gebed. Prediking sonder epiklese is nie prediking nie. Wie nie kyrie eleison kan sê nie, kan nie preek nie. Om te preek, is om die arms na God toe uit te strek, nie alleen met jou onsekerheid en gebrokenheid nie, maar ook met die verwagting dat God Homself hier en nou só gaan openbaar, dat sy Misterie verdiep. Om te preek, is om leeg voor God te staan, óóp voor Hom, vól vrae, afwagting, spanning - wat altyd weer uitmond in Veni, Creator Spiritus! (Kom, Skepper-Gees)

\subsubsection{OM TE PREEK, IS OM TE GRYP NA DIE GORDYN}

God openbaar Homself inderdaad in die prediking. Sy stem kán gehoor word. Van hierdie verwagting (hoop) lééf die prediking, en in hierdie hoop volhard dit, sugtend met geduld dat dit nou tog so sál wees (vgl. Rom. 
$8: 22-26)$. Wat in die prediking gebeur, is veel meer as net religieuse praatjies, dis 'n uitdeling van die heil. Die gemeente - en die wêreld - het inderdaad die reg om presies dít van die prediking te verwag: dat God se stem hier deur 'n mensestem hoorbaar sal word. Frederick Buechner verwoord hierdie (meestal onuitgesproke) verwagting raak in sy boek Telling the Truth (1977:22-23):

"The sermon bymn comes to a close with a somewhat unsteady 'amen' and the preacher climbs the steps to the pulpit with his sermon in hand. His mouth is a little dry. He cut bimself shaving. He feels as if he bas swallowed an anchor.

"In the front pews an old man turns up bis bearing aid while a young mother slips ber 6-year-old a lifesaver and Magic Marker. A college sophomore home for vacation, there because be was dragged there, slumps forward, chin in his hands. The vice-president of the bank, who twice that week seriously contemplated suicide, places his bymnal in the rack. A pregnant teen-age girl feels life stir within ber body, a high school math teacher, keeping his homosexuality a secret, creases the bulletin down the center with his thumbnail and tucks it under bis knee.

"The stakes have never been higher. Two minutes from now the preacher may have lost his listeners completely to their own thoughts, but at this moment, the silence is deafening. Everyone knows the kinds of things he bas told them before, but who knows what this time, out of his silence, be will tell them."

Om te preek, is om uit die stiltes voor God te praat, uit die stiltes waaruit sy Woord gebore word, omdat Hy dié stiltes met Homself vul. Om te preek, is om in die Allerheiligste van God se openbaring ingebring te word. Dis om mense te stel voor die ark van die verbond, om die gordyn weg te skuif van dié Allerheiligste, en dinge te sien wat jy nog nie tevore gesien het nie. Goeie prediking, sê Miskotte, is "de greep naar het gordijn, dat de Ark verbergt." (1976:206-207). Dit beteken nié dat ons die werk van Christus uit sy hande wil neem nie. Die voorhangsel het kláár geskeur, van bo tot onder, middeldeur (Mark. 15:38). God het klaar die sluier weggeneem (2 Kor. 3:14-18). By God is daar geen gordyn nie, maar by óns hang die gordyn, wat telkens weer in die prediking weggeskuif moet word, sodat ons insig in die Allerheiligste kan verkry. Om te preek, is om gordyne weg te skuif, aanbiddend maar beslis, omdat die gordyn weggeskuif, ja oopgeskeur ìs. En as die gordyn weggeskuif is, mag ons vra: Sien julle dit nou gemeente? Weet julle dat julle in die Allerheiligste is? Hy is nóu rondom julle, rondom ons almal, ja, Hy omsluit ons van alle kante (Psalm 139:5). 


\subsubsection{OM TE PREEK, IS OM DIE WOORD TE VERTROU}

Hierdie evangelie is ook ons enigste troos as predikers. Hierdie Woord mag ons met ons hele hart vertrou, sonder om iets by te voeg (Barth 1964:89). Dit mag óns woorde wees wat ons mond verlaat, maar op weg na die ore van die hoorders verander die Gees ons woorde in die woorde van Christus, ja, in die lewende Woord sélf. Daar vind, soos in die nagmaal, 'n soort transsubstansiasie plaas (Miskotte 1976:200): ons woorde word die Woord, die Verlossingswoord, waarin en waardeur Christus self die vrugte van sy verlossingswerk uitdeel. God is in sy Woord teenwoordig - Hy ry binne op die Woord van die waarheid, sê Miskotte. Hy gee antwoord. Hy is sélf die laaste Antwoord op die laaste en diepste vraag van ons lewens. Met hierdie koms van God in ons midde, staan en val álles in die prediking én trouens in die hele erediens. Christus voer sélf sy Woord, is sélf die Woord wat verlossing in ons bewerkstellig: "En hier sien $u$ 'n groot geheim. Die klank van ons woorde tref julle ore, maar die Leermeester is binne julle. Moenie dink dat julle bloot iets van 'n mens leer nie. Ons kan julle vermaan deur die geluid van ons stem. Maar as daar nie binne julle Iemand is wat julle leer nie, bly ons geluid tevergeefs... Die onderwysinge van buite af is bepaalde bulpmiddels en opwekkinge. Maar Hy wat die harte leer, se preekstoel staan in die bemel. Daarom sê Hy self in die evangelie: laat julle nie leraars op aarde noem nie, want één is tog julle leraar, naamlik Christus."(Augustinus; vgl. Van Oort 1991:26; ook 1989:84)

Die Woord in ons woorde! Dáárin lê die wese van die prediking. Die prediking bestáán uit mensewoorde, en tog is dit ook veel meer as dìt, veel meer as net 'n ekserp wat uit 'n woordeboek gedoen en in 'n meer of minder suksesvolle wyse in 'n redestroom saamgevoeg word. Prediking geskied met die geloof en hoop dat God sélf sy Woord by ons preekwoorde sal inmeng, só, dat ons baie woorde op een of ander manier tóg as God se Woord gehoor sal word, en dat Hy sélf ter sprake sal kom.

Inderdaad: Om te preek, ís om so oor God te praat, dat Hy self kan praat...

\subsection{As God praat, hoor ons die evangelie van verlossing}

Die wonder van die prediking is dit: God is teenwoordig. Hy praat met ons. Maar, Hy praat op 'n spesifieke manier. Hier verdiep die wonder nog verder, want, as God praat, staan sy genade altyd voorop. Die feit dat God op 'n verrassende en oorstelpende, op 'n nuwe en vreemde manier na sondige mense toe kom en hulle verlos - dit is die evangelie. Dat Hy teen 
alle verdienste óf skuld van mense in die inisiatief neem en hulle herskep vir Homself - daarvan is die Bybel vól. Net sodra die volk van God dink hulle gaan nou onder in die toorn van God, en die vlamme al letterlik begin opskiet om hulle te verteer, hoor hulle: Moenie bang wees nie, Ek verlos jou, Ek bet jou op jou naam geroep, jy is Myne. As jy deur water moet gaan, is Ek by jou, deur riviere, bulle sal jou nie wegspoel nie; as jy deur vuur (FC: ook dié van die oordeel!) moet gaan, sal dit jou nie skroei nie, die vlamme sal jou nie brand nie, want Ek is die Here jou God, die Heilige van Israel, jou Redder (Jes. $42: 25 ; 43: 1-3)$.

Ja, selfs wanneer God sy oordeel aankondig, is dit (die voorloper tot) sy genade. Is dit niks anders nie as sy gekwetste liefde. Is sy toorn tegelykertyd sy omhelsing van genade (Luther). Sonder enige verdienste van ons kant af, as 't ware uit die bloute, lynreg uit die hemel uit, kom die verlossing na ons toe. God het sy toorn in Homself ingetrek, en op sy Seun uitgegiet. Jy hoor dit in die gesteun in sy innerlike wese, in die worsteling van sy liefde - al in die Ou Testament: Maar boe kan Ek jou prysgee, Efraim? Hoe kan Ek jou laat vaar, Israel? Hoe kan Ek jou vernietig soos Adma, met jou maak soos met Sebojim? Ek kan dit nie oor my hart kry nie. My liefde brand te sterk. Ek sal my gloeiende toorn bedwing, Ek sal nie so ver gaan en Efraim uitwis nie, want Ek is God, nie 'n mens nie. Ek is die Heilige wat by jou is, Ek sal nie met woede ingryp nie (Hos. 11:8,9).

Predikers word geroep om allereers en sonder ophou van hierdie onvergelyklike evangelie van God se genade te getuig, om dit uit te wys. Om uit te roep: God ís liefde (1 Joh. 4:8). Nie toorn nie. Goddank! Om te verklaar: die liefde van God is hier, dis 'n werklikheid, dis wáár, dis vir jóú. Jy kan dit nie keer nie, nie beheer nie. Dit val uit die lug soos reën, soewerein, meestal onverwags en onkeerbaar. Wie kan die druppels stop? Wie kan die reën terugjaag hemel toe? Nee, God laat sy reën val op dié wat reg doen én op dié wat verkeerd doen (Matt. 5:45).

Dit laat 'n mens dink aan wat Thomas Merton (1977:42) in 'n ander verband oor die reën skryf. Dit word vir hom 'n simbool van die lewe, van die ruimheid en goedheid van die natuur, van geborgenheid in 'n groter geheel:

"Die reën waarna ek nou luister is anders as dié wat in die stede val. Dit vul die woude met 'n grootse en dawerende klank. Dit bedek die plat dak van die huis en sy stoep met sy aanhoudende en gekontroleerde ritmes. En ek luister, want dit herinner my keer op keer dat die wêreld funksioneer volgens ritmes wat ek nog nie geleer het om te berken nie, ritmes wat nie dié van menslike ingenieurs is nie... geen mens het die reën laat begin nie, en niemand gaan dit stop nie. Dit sal so lank op my dak bly praat soos dit wil, bierdie reën. En, solank as wat dit praat, sal ek luister..." (Vry vertaal uit: Raids on the unspeakable) 
Só is die genade. Vry, onkeerbaar, orals om ons. En ons mag dit preek!

Om dié genade te preek, beteken om Christus te preek. Niks meer nie, niks minder nie, niks anders nie. Maar... dis geen vanselfsprekende saak dat ons wél Christus preek nie. Grondige eksegese en "korrekte" prediking waarborg nie sondermeer dat dit gebeur nie. Trouens, dit kan selfs 'n struikelblok wees as jy bloot hierop vertrou om die evangelie te kan preek. Grondig en korrek is nie altyd rég nie. Korrek kan wees om die regte bladmusiek, met die regte note voor jou te hê - maar dis nog nie die musiek nie. Die swart note op papier moet musiek in die ore word, anders ìs dit nie eintlik musiek nie!

In die prediking van die evangelie gebeur daar altyd méér as wat ons kan mak, gebeur die wonder van die onmaakbare - hoewel dit ons geensins ontneem van ons verantwoordelikheid om alles in ons vermoë te doen om die preek te máák nie!

\subsubsection{DIE KENMERKE VAN DIE PREDIKING VAN VERLOSSING}

Maar, hoe lyk dié prediking van verlossing dan waarvan ons tot dusver gepraat het? Waaraan kan jy dit herken? In die eerste plek moet ons sê: dis 'n gawe van die Heilige Gees, en 'n kuns wat ons telkens weer geleer moet word. As ons dus probeer aandui watter vorm hierdie prediking van die verlossing moet aanneem, sal ons altyd moet onthou: daar bestaan nie resepmatige voorskrifte nie, alleen maar aanduidinge wat jy meestal beter in retrospeksie kan raaksien as om dit vooruit te bepaal; daar is alleen maar taaltekens dat die goeie nuus van die evangelie in hierdie konkrete preek opgeklink het. Hierdie taaltekens hang na my mening egter weer onlosmaaklik saam met, en is uitvloeisels van, die volgende ses grondlyne en kenmerke wat geld vir die prediking van verlossing:

\subsubsection{Die crux van verlossingsprediking: niks anders as Christus nie}

God openbaar Homself as Triniteit; daarom moet die prediking, of dit nou oor die Ou of Nuwe Testament handel, ook altyd trinitaries wees. 'n Basiese, homiletiese reël - die ABC daarvan - lui: Prediking het altyd te make met die verkondiging van die realiteit van die teenwoordige, verlossende God, van die werke van die Vader, Seun en Heilige Gees. Maar wat ' $\mathrm{n}$ ABC is dít nie! Eerder 'n Alfa en Omega...

Ons moet die werke van die Drie-enige God verkondig, én ons word geroep om Christus te verkondig (vgl. 1 Kor. 2:2: Ek het my voorgeneem om met julle oor niks anders te praat nie as oor fesus as die Christus, en wel oor Hom as die gekruisigde.) Ook Luther het hom sterk hieroor uitgedruk: nibil nisi 
christus praedicandus (niks anders as Christus verkondig nie; vgl. Meuser 1983:38). Die punt is: Alle lyne in die prediking loop uiteindelik na Christus toe, en alle strale skiet van Hom af uit. Maar...hoe verkondig ons niks anders as Christus nie, en tog die Triniteit? Dit is 'n komplekse vraag, wat ook saamval met die vraag na die verhouding tussen Ou en Nuwe Testament, en kan nie hier in besonderhede behandel word nie. ${ }^{12}$ Die volgende geld slegs as algemene riglyne:

Daar kan alleen werklik Christologies gepreek word vanuit 'n geïntegreerde, teologiese visie op die werk van die Drie Eenheid. Indien die werk of wese van die Triniteit na die een of ander kant toe in die prediking skeefgetrek word, volg die teologiese misvorminge as ' $t$ ware vanself - of dit nou doketisme, spiritualisme of 'n onhoudbare soort Jesulogie is. Nee, prediking is verlossingsprediking, is evangelieprediking, is prediking van die goeie nuus dat die God van die Ou én die Nuwe Verbond ons uit genade vryspreek om aan Hom gehoorsaam te wees. Die evangelie is nie beperk tot die Nuwe Testament nie, net so min as wat die wet beperk is tot die $\mathrm{Ou}$ Testament. Wel kan ons sê dat die dieptepunt van God se verlossingswerk in Christus te vinde is, en dat die prediking van verlossing soos dit in alle Bybelse tekste tot openbaring kom, op een of ander manier altyd moet deurdring tot hierdie dieptepunt.

Laasgenoemde is veral problematies as dit kom by prediking uit die $\mathrm{Ou}$ Testament. Om Christosentries te preek, en nie bepaalde tekste voortydig met 'n Christomonistiese dogma te vereng nie, vra inderdaad teologiese integriteit. Die Christologie kan juis hier maklik omskep word in 'n newelagtige soort fesulogie, wat die verkondiging van verlossing van alle krag beroof. Rein Bos (1992:267-272) wys op 'n aantal slaggate in dié verband, onbegaanbare weë waarin die Ou Testament grotendeels agter Christus verdwyn, en dus nie tot sy reg kom nie:

- Die Christologiese verenging van die Ou Testamentiese teks. In hierdie geval word die ganse teks as voorspelling gesien, wat in Christus waar word. Die Ou Testament word dan in die prediking bloot gebruik as 'n inleiding tot die "eintlike" boodskap, en kry nooit die kans om as 't ware sy eie hart uit te praat nie. Die ironie is dat die verlossingsboodskap juis van sy diepte ontneem word, en dat die legitieme Christologiese moontlikhede van die teks deur die Jesulogie onderdruk word.

- Die Christologiese vergroting van die Ou Testamentiese teks. In hierdie model word Jesus verkondig as die Een wat op 'n unieke wyse die

12 Vir 'n uitgebreide bespreking, vgl. Holmgren, FC 1997. The Old Testament and the Significance of Jesus. Maintaining Christian Identity; Seitz, CR 1998. Word without End. The Old Testament as Abiding Theological Witness, om slegs twee te noem. 
moraal van die teks vervul het. Die morele eis wat daar van Bybelse figure (Abraham, Moses, Dawid, ens.) uitgaan, word dan versterk deur die feit dat Christus hulle almal ook nog oortref het. Die ironie is weereens dat die legitieme Christologiese moontlikhede van die teks deur die Jesulogie ondedruk word, hierdie keer deur die Jesulogie van die moralisme.

- Die Christologiese verskeuring van die Ou Testamentiese teks. Soms gebeur dit dat predikers eintlik twee prekies in een wil hou, naamlik ' $\mathrm{n} O \mathrm{Ou}$ Testamentiese én 'n Nuwe Testamentiese, dikwels ook letterlik met twee Skriflesings. Die gevolg is dat nie een van die twee tekste tot hulle reg kan kom nie, dat die verbande tussen die twee mini-preke onduidelik, en die oorgang abrup is. Erger nog: dat die Ou en Nuwe Verbond uitmekaargeskeur word.

- Die Christologiese punktuasie van die Ou Testamentiese teks. Hier word die Christologie gewoon as 'n soort slot agter elke en enige Ou Testamentiese teks gevoeg, dikwels ook nog op 'n stereotiepe wyse. So 'n soort slot moet dan agter elke preek pas, met die implikasie: alle tekste sê uiteindelik maar dieselfde ding. Dis weliswaar 'n poging om Christologiese sanksie aan $\mathrm{Ou}$ Testamentiese tekste te gee, maar die ironie is weereens dat die rykdom van moontlikhede, ook Christologiese moontlikhede, met hierdie voorspelbare punktuasie gedemp word.

- Dat hierdie nie 'n eenvoudige saak is nie, is duidelik. In ' $n$ sin is dit moontlik die hoogste kuns en wetenskap, die diepste geheim van die prediking: om niks anders as Christus te verkondig nie, maar dit steeds binne die rykdom van die Bybelse teks, en vanuit 'n geïntegreerde, trinitariese teologie te doen. Ons roeping ís om Christus te verkondig - dit bly in hierdie boek my uitgangspunt, soos dit ook met Cranach se skildery op die buiteblad versinnebeeld word. Die kruisdood en opstanding is immers die kern, die "belangrikste" skarnier waaromheen die hele evangelie draai (vgl. 1 Kor. 15: 3-8).

\subsubsection{Die prediking van verlossing is 'n woord oor God...}

Die prediking van verlossing is altyd primêr - soos ek reeds bo aangetoon het - die goeie, verrassende nuus van die handelinge van God. Daarom moet ons ons taalgebruik in die prediking altyd vanuit hierdie oortuiging bly bevraagteken: Wat sê dit oor God? En ook: Hoe praat die preek oor God? Die prediking moet altyd teologies van aard bly, dit wil sê 'n woord oor God en sy handelinge bly uitspreek. Omdat dit in die prediking oor die handeling van God gaan, hoor ons ook altyd iets nuuts, iets wat ons nog nooit voorheen gehoor het nie, al is dit die ou, ou tyding. Verkry ons altyd weer 'n nuwe perspektief op die onuitspreeklike genade van God. En word ons 
in die prediking van die evangelie ook altyd verras met 'n nuwe vreugde, altyd verstom deur 'n nuwe hoop, terwyl ons gedink het daar bestaan nie meer só iets nie...

Prediking wat dít nie doen nie, wat nie die grootsheid van ons verlossing uit die sonde tot dankbaarheid uitspel nie, verval in bumanisme. Keer ons op onsself in - in plaas daarvan om ons te bring by dié belydenis: God is aan die werk, Hy het gewerk, Hy sal werk en Hy werk nóú. Hy is 'n teenwoordige Realiteit. Die onvergelyklike Werksame. Sy koninkryk het gekom, sal kom, en kom nou. Wie kan die seën van sy reen keer?

Nee, ons kán nie, hóéf nie God se werk uit Sy hande te neem nie...

Dikwels verraai ons woorde, ons grammatika dat ons dít ten diepste nie verstaan nie. Dat ons, met respek gesê, die Here tóg maar so 'n bietjie wil aanhelp of te hulp wil snel. Verklap dit ons teologie, of dan, gebrek daaraan. Soms lyk en klink dit asof ons oor God praat, maar eintlik praat ons oor onsself (vgl. 3.7 vir uitgebreide voorbeelde hiervan).

Nee, God se genade gaan alles vooraf. Die uitverkiesingsleer is inderdaad die somtotaal van die evangelie (Barth), en daarom die primêre teologiese onderbou van die prediking van die evangelie. Die volgende meditasie onderstreep dit:

"Die vooraf-genade van God. 'n Genade wat my geloof én my ongeloof voorafgaan, my gebede én my biddeloosheid, my vroomheid én my onheiligheid, my berou én my gebrek aan berou.

Wat is 'n mens se lewe? 'n Stukkie tyd wat jou op die tydslyn tussen jou geboortedatum en jou sterfdatum gegun word. Sewentig jaar, of tagtig, as jy baie sterk is (Psalm 90:10). En tussen jou geboortedatum en jou sterfdatum beleef jy jou kwota soet en suur, jou vreugde en verdriet, jou hartseer en hoop. En, deur God se genade mag die ewigheid êrens hierdie stukkie tydslyn van jou kruis en jy 'n besluit vir die Here neem - 'n gebeurtenis waarvan die betekenis inderdaad eers in die ewigheid vir jou ten volle duidelik sal word, en waarvoor die ewigheid veels te kort sal wees om God ten volle te dank. So is dit. Maar dit sou 'n fatale fout wees as ons begin dink dat ons verlossing eers in hierdie beslissingsmoment van ons gebóre word, dat dit geheel en al afhanklik is van óns besluit. Fulle het My nie uitgekies nie, maar Ek bet julle uitgekies, het Jesus op 'n keer vir sy dissipels gesê (Joh. 15:16). Ons verlossing word gebore in God se beslissing, is geheel en al afhanklik van God se besluit, van sy vooraf-genade... toe ons nog magteloos was, toe ons nog goddeloses was, toe ons nog sondaars was. God sê: Voordat jy gebore is, het ek al van jou gedroom." (Aangepas uit: Johan Cilliers: In die greep van God). 
Een van die grootste raaisels, nee tragedies, bly seker die feit dat ons - hoe onverstaanbaar dit ookal klink - ons teen hierdie onweerstaanbare genade van God kan verset. Ons natuurlike neiging is tog maar weer om die geregtigheid in onsself te gaan soek - Ek vas twee keer in die week en gee ' $n$ tiende van my bele inkomste verklaar die Fariseër en loop daarmee die ware geregtigheid mis (Luk. 18:11,12). Ons oersonde bly steeds ons blatante, maar meestal verfynde hoogmoed (Augustinus). Ons is meesters in subtiele, maar fatale verskuiwings: dit wat God beskik, verander ons in dit wat ons besit; dit wat God besluit, word dit wat ons bereik; dit wat 'n vrye gawe van God is, word gawe mense met vermoëns; dit wat die vooraf-genade van God is, word die verwerfde genade van mense.

Maar, daar is géén plaasvervanger vir die evangelie van genade nie...

\subsubsection{3 ... en 'n woord ván God.}

Prediking van verlossing is egter ook altyd meer as net 'n woord óór God, dis ook 'n woord ván God; meer as net inligting oor verlossing, eerder 'n gebeure van verlossing self; meer as net 'n uitspraak, eerder 'n vryspraak. Die evangelie doen immers altyd wat dit sê, bring tot stand wat dit onder woorde bring. Die Bybelse teks is nie bloot informatief nie, maar ook performatief: as God se Woord keer dit nie onverrigter sake na Hom toe terug nie, maar dit doen wat God gedoen wil hê en bring tot stand waarvoor Hy dit gestuur het (vgl. Jes. 55:11). Alreeds die Hebreeuse begrip vir "woord" (dabar) dui nie bloot op “iets" nie, maar is self 'n gebeure, 'n heilsgebeure. In die Woord kom God sélf na ons toe. Hy is sélf die Woord, die Skeppings- en Herskeppingswoord, wat nie alleen alles wat bestaan tot stand geroep het nie, maar ook die dooies tot lewe roep (Joh. 1:1-3; Rom. 4:17). Deur die prediking van dié Woord word ook die kerk gekonstitueer (as 'n creatura verbi), en word ons tot nuwe mense verander.

Ons preek dus nie in die eerste plek, soos ons reeds benadruk het, bloot woorde of 'n "boodskap" of selfs 'n teks nie, maar 'n Persoon: Jesus Christus self. Waar $H y$ verkondig word, word bevestig dat hierdie uur, hierdie kairos onder die heerskappy van dié Woord staan. Prediking is die bevestiging dat die tyd, hiérdie tyd met sy nood en pyn voor die aangesig van God afspeel, deur Hom onderhou word, en deur Hom na sy toekoms gevoer word. Die prediking van die evangelie is daarom nie bloot 'n algemene waarheid of 'n pedagogiese leerstuk of 'n historiese mededeling of 'n psigologiese wysheid of 'n sosiale program nie, maar die uitroepteken oor die Heerskappy van Christus oor die ganse werklikheid.

Dit bly ons troos en uitdaging wanneer ons met die Woord omgaan, en ook in die prediking daarmee worstel: dié Woord is 'n effektiewe Woord (Luther: verbum efficax). Die evangelie is vol belofte, wat ook in die predi- 
king deur God self waar gemáák word. Daarmee staan of val inderdaad alles in die prediking.

Die feit dat God self die beloftes van sy Woord in die prediking waar maak, het verreikende implikasies vir die manier waarop ons oor die verlossing praat, of eerder: waarop die verlossing (Verlosser) in ons woorde ter sprake kom. Prediking wat vryspraak is, het altyd 'n gerigtheid op die teenswoordige tyd. Dit vertel nie slegs die verhaal van 'n verloopte heilsgeskiedenis, of deel nie bloot metafisiese informasie mee, of gee nie psigologiese interpretasies van menslike probleme deur nie. Dit is meer as net 'n getuienis van die heil, eerder 'n teenswoordige heilsgebeure, soos dit in dié spesifieke prediking van die Woord manifesteer. Die Woord, en die prediking daarvan, maak geskiedenis, skep tyd, beilstyd: Kyk, nou is dit die regte tyd, nou is dit die dag van redding (2 Kor. 6:2b).

Daarom het die prediking van verlossing ook altyd 'n gerigtheid op 'n spesifieke adres. Prediking wat vryspraak is, is meer as algemene waarhede wat aan enigeen oorgedra sou kon word, bevat meer as net teologiese leerinhoude, Christelike wêreldbeskouings of Bybelse antropologieë - hoe belangrik en leersaam dit alles ook al mag wees. Prediking wat vryspraak is, praat met spesifieke mense, op só 'n manier dat hulle deur die Een wat hulle vryspreek, bevry word van sonde, dit wil sê van bulleself. Dit spreek egter ook die omstandighede en strukture aan waarbinne spesifieke mense hulleself bevind. Jy kán byvoorbeeld nie die evangelie op presies dieselfde manier preek tydens die Tweede Wêreldoorlog én die jaar 2003 nie. Want die evangelie "pas in" by die tyd en die plek en die omstandigheid, as ou, ou tyding ja, maar as goeie nuus vir hiér en nóú. (vgl. breedvoeriger hieroor hoofstuk 5)

'n Mens weet eintlik nooit vooraf wat in 'n preek gaan gebeur nie, omdat die Wie wat daarin gebeur, vrymagtig is. Hy handel soos Hy wil, waar Hy wil, wanneer Hy wil. Daarom moet predikers ook sensitief bly vir die (soms vreemde) werking van die Woord in die erediens. 'n Erediens is immers meer as 'n netjiese, voorafuitgewerkte program wat foutloos vanaf A tot $Z$ moet verloop. Natuurlik moet ons so goed as wat ons kan voorberei, maar tegelykertyd tog ook weet: die Here is nie gebonde aan preke of programme nie. Soms kom daar dimensies in 'n erediens wat jy glad nie verwag het nie, verbredings van jou denke en belewenis wat jou asem wegslaan. Dan is dit belangrik dat die predikant hierdie beweging sal opvang, sensitief sal wees vir 'n bepaalde atmosfeer, en kan "improviseer". En nee, dis geen alibi vir liturgiese en homiletiese luiheid of slordigheid of wispelturigheid nie, eerder 'n openheid vir liturgiese en homiletiese boop.

In die prediking is ons nie besig met speletjies of vermaaklikheid nie, maar met lewe en dood. Daarom moet ons na die prediking luister met die verwagting dat dié God, wat ons uit die dood tot die lewe geroep het, dit 
in hierdie preekoomblik weer gaan doen. Ons mag op die kansel klim met die hoop dat ons 'n ontmoeting met niemand minder nie as die Lewende God self gaan hê, ja, dat die Persoon van die sprekende God sélf onder die preekwoorde na ons toe aangestap gaan kom. En die gemeente moet iets opvang van dié verwagting, die tinteling, die hoop: hier gaan vandag iets gebeur met óns in ons spesifieke omstandighede; hier, in die woorde van die predikant spat daar vonke wat lewe kan gee, is daar 'n $\mathrm{krag}$ wat die lammes kan laat opstaan.

Dit laat'n mens dink aan die Rabbynse verhaal van die man wat lam was en op 'n dag vertel het van sy held, Baal Sjem Tov. Hy was nog entoesiasties aan die beduie hoe dié held van hom altyd rondgespring en gedans het wanneer hy baie ernstig gebid het, toe hyself skielik uit sy rolstoel uit opgestaan en presies volgens sy eie woorde begin rondspring en dans! Sy woorde bet in, en aan homself wáár geword. Van daardie oomblik af was hy van sy lamheid genees. En nee, daarmee bepleit ek nie nou weer noodwendig liturgiese danse of rituele rondspringery nie, maar 'n houding, ' $n$ styl van verwagting. Die Woord in ons midde is die Lewende Woord. Hy wérk. Hoe kán ons in ons rolstoel bly sit as ons oor Hom preek en na Hom luister?

\subsubsection{Die prediking van verlossing is die voort-en verder vertelling van 'n verhaal...}

Die heil het in die geskiedenis teenwoordig geword, daarom kan dit ook in die prediking in geskiedenisse teenwoordig gestel word. Die narratief het 'n evangeliese dimensie (Josuttis). Onder die begrip "narratiewe prediking" verstaan mense egter dikwels verskillende dinge. 13 'n Mens sou - oorvereenvoudig gestel - minstens die volgende "vlakke" daarin kon onderskei:

- Eerstens, die blote vertel van "stories" in preke, dikwels op die effek af, of sommer net omdat die storie 'n "goeie storie" is. Dan word die storie 'n doel in sigself, en word die Bybelse teks slegs as bykomstig by die

13 John McClure verwys byvoorbeeld na narratiewe hermeneutiek (wanneer die woord narratief in verband met Bybelse materiaal in die prediking gebruik word), narratiewe semantiek (dit hou verband met die preekvorm), narratiewe enkulturasie (dit verwys na kultuur en menslike ervarings) en narratiewe wêreldbeskouing (spesifiek die teologiese wêreldbeskouing of geloofsverhaal) (1991:25-27). Lucy Rose handhaaf ook vier onderskeidings: narratief in verband met die doel van die prediking, Bybelse hermeneutiek, die taal van prediking, en die rangskikking van preekmateriaal (1997:1-11). Eugene Lowry verwys na drie vlakke: narratiewe homiletiek, narratiewe hermeneutiek en narratiewe teologie (1995: 342). 
storie verstaan, as 'n soort eksegetiese stawing van die waarde of waarheid van die storie. Stories het 'n meevoerende $\mathrm{krag}$, en veral stories wat 'n negatiewe sentiment dra kan uiteindelik die preek en die Bybelse teks totaal oorwoeker (vir voorbeelde, vgl. 3.7).

- Die tweede vlak van narratiewe prediking is die eietydse oorvertelling van Bybelse verhale, op só 'n manier dat die algemene strekking van die verhaal nog gevolg word, maar die historiese data verskil. Jy kan dus die Bybelse verhaal in die eietydse "verlenging" of "voortvertelling" daarvan duidelik herken.

Philip Yancey, die Amerikaanse joernalis-teoloog, vertel byvoorbeeld sommige van die gelykenisse van Jesus op só 'n eietydse manier oor, gegrond op werklike, hedendaagse gebeurtenisse (In: What's so amazing about grace?). Soos dié een, wat jou weer lus maak om oor die gelykenis van die groot bruilofsmaal te preek! -

"'n Verloofde paartjie het na die eksklusiewe Hyatt Hotel in Boston gegaan om reëlings vir hulle bruilofsonthaal te tref. Hulle het egter albei duur smaak gehad en net die beste uitgekies: die voortreflikste spyskaart, die indrukwekkendste silwerware, die mooiste blommerangskikkings. Die rekening het op dertienduisend dollars te staan gekom. Hulle het die helfte as 'n deposito inbetaal, en vertrek om na troukaartjies te gaan kyk.

Op die dag toe die troukaartjies uitgestuur moes word, het die bruidegom egter van plan verander, en gevra dat hulle die troue moes afstel. Sy verloofde was kwaad en hartseer, en het na die Hyatt Hotel gegaan om die onthaal te kanselleer. Daar moes sy tot haar ontsteltenis hoor dat sy slegs 'n klein gedeeltetjie van die deposito sou kon terugkry. Sy het twee opsies gehad: of om die geld prys te gee, of om maar deur te druk met die reëlings.

Dis toe dat die bruid die roekelose idee gekry het om voort te gaan met die onthaal, nie as 'n huweliksbanket nie, maar sommer net as 'n reuse-feesparty. Die rede? Miskien was dit omdat die bruid tien jaar tevore 'n inwoner van 'n skuiling vir dakloses was. Sy het egter haar voete gevind, 'n werk gekry, en met die tyd 'n redelike bedraggie spaargeld opsygesit. Nou het sy besluit om al die dakloses van Boston vir 'n aand te nooi wat hulle nooit sou vergeet nie, en amptelike uitnodigingskaartjies na al die skuilings vir dakloses in Boston laat stuur.

So het daar op 'n warm someraand in Junie 1990 'n onthaal in die eksklusiewe Hyatt Hotel plaasgevind, soos die personeel nog nooit beleef het nie. Mense het van heinde en verre opgedaag: vertoiingde bejaardes met krukke en loopringe, mense wie se aardse besittings in 'n supermarktrollie kon inpas, boemelaars wat gewoond was om onder kartonne te slaap, verslaafdes wie se harde lewe op hulle gesigte geskryf 
gestaan het. Hulle het aangesit by die tafels met die kraakwit linne en die gepoleerde silerware, is bedien deur kelners in aandpakke, het gesmul aan die vyfgangmaaltyd wat deur van die beste kokke in die wêreld voorberei is. Soos wat die aand gevorder het, het hulle sjampanje gedrink, troukoek geëet en geluister na die strelende musiek wat deur die simfonieorkes verskaf is. Só 'n skreiende kontras tussen onverdienstelike gevalle aan die een kant en weelderige feesvieringe aan die ander kant het jy in jou lewe nog nooit gesien nie...

Behalwe... in die evangelie.

Kyk mooi: tussen die tafels deur stap die Gasheer.

Sy glimlag sê alles."

Hoor 'n mens nie die blye nuus van die evangelie op 'n treffende wyse hierin nie?

- Die derde vlak van narratiewe prediking is die vertel van 'n eietydse verhaal wat op die oog af glad nie die strekking van enige Bybelse verhaal volg nie, maar nogtans die teologiese kern van 'n spesifieke teksvers of die Bybelse Boodskap in die algemeen weergee en illustreer. 'n Mens kan, indien jy sensitief genoeg daarvoor is, hierdie soort verhale feitlik orals raaklees. Die werke van Dostojevski is byvoorbeeld vól sulke juwele. Ook dié van Victor Hugo.

In Victor Hugo se roman Les Misérables hoor 'n mens die aangrypende verhaal van 'n Fransman genaamd Jean Valjean wat 'n negentien jaar lange tronkvonnis opgelê word net omdat hy 'n bietjie brood gesteel het. In die tronk word hy algaande 'n geharde misdadiger. Niemand kon hom in 'n vuisgeveg klop nie. Niemand kon sy wil breek nie. Uiteindelik word hy vrygelaat, maar omdat misdadigers in daardie dae spesiale identiteitskaarte moes dra, wou geen herbergier dit waag om so 'n gevaalike man onder sy dak in te neem nie. Vir vier dae lank het hy deur die strate van die dorp gedwaal en teen die wind en weer probeer skuil, totdat 'n barmhartige biskop hom oor hom ontferm het.

Daardie nag het Jean Valjean stil in sy bed gelê en wag totdat die biskop en sy suster aan die slaap geraak het. Hy het opgestaan, in die kombuiskas gesoek totdat hy afgekom het op die familie se kosbare silwerware, en homself uit die voete gemaak.

Die volgende oggend het drie polisiemanne by die voordeur van die biskop kom klop. Agter hulle het Valjean in boeie gestaan. Hulle het hom op heterdaad betrap waar hy besig was om te vlug met die familie se kosbare silwerware, het hulle gesê, en wou dit net kom bevestig voordat hulle hom vir die res van sy lewe in kettings sou sit. Die biskop se reaksie het almal se voete onder hulle uitgeslaan, veral dié van Jean Valjean.

"So, hier is jy!" het hy gesê terwyl hy hom stip in die oë kyk. "Ek is so 
bly om jou te sien. Het jy dan vergeet dat ek jou die kandelare ook gegee bet? Hulle is ook silwer soos die res, en sekerlik 200 frank werd. Het jy vergeet om dit saam te neem?"

Die misdadiger het die biskop met groot oë aangestaar, met 'n gesigsuitdrukking wat nie met woorde beskryf kon word nie.

"Hierdie man is nie 'n dief nie" het die biskop vir die polisie gesê. "Die silwerware was my geskenk aan hom."

Toe die polisie weg was, het die biskop die kandelare aan sy gas gegee, wat nou spraakloos en bewend voor hom gestaan het. "Moenie vergeet nie, moet nooit vergeet nie dat jy my belowe bet dat jy die geld wat dié silwerware oplewer sal gebruik om van jouself 'n eerlike man te maak nie," het die biskop gesê.

Is dít nie nou 'n klassieke verhaal van onverdiende genade, van vrye guns alleen nie? Want hier word 'n opperste skelm vrygespreek, meer nog, word hy met rykdom oorlaai, sonder 'n greintjie van verdienste van sy kant af. Trouens, dit geskied lynreg teenoor sy verdienste, voordat daar hoegenáámd sprake kon wees van selfs maar net 'n sprankie van berou by hom.

Dieselfde verhaal van onverdiende genade hoor 'n mens tog ook in die evangelie, net baie asemrowender, want hier handel dit om 'n veel groter skuld en 'n veel groter vryspraak. Dit staan byvoorbeeld opgeteken in verse wat al die oer-evangelie genoem is, of ten minste die evangelie in 'n neutedop:

Toe ons nog magteloos was, het Christus immers reeds op die bestemde tyd vir goddeloses gesterwe... Maar God bewys sy liefde vir ons juis hierin dat Christus vir ons gesterf het toe ons nog sondaars was (Romeine 5:6,8).

- Die vierde vlak van narratiewe prediking is die spesifieke uitgangspunt dat die prediking - watter vorm dit ookal mag aanneem - niks anders mag oorvertel as die meesterverhaal van Jesus nie. Dié verhaal bly die norm waarteen alle narratiewe elemente in die prediking gemeet moet word. Hier handel dit egter oor meer as net verhale of stories in die gewone sin van die woord. Die meesterverhaal van Jesus kan ook in "dogmatiese" of "lerende" preke oorvertel word - solank dit net berus op die verhaal (geskiedenis) van die heilsgebeure in Christus, te wete sy menswording, lyding, opstanding en triomf. In die preke van Luther kan byvoorbeeld feitlik alle "narratiewe strome" wat daardeur vloei, teruggevoer word na sy passie om niks anders nie as Christus te verkondig (Josuttis).

Wat ookal jou uitgangspunt mag wees - verhale mag nie bloot vertel word met 'n retoriese intensie om effek te bewerkstellig of slegs die 
boodskap te veraanskoulik nie. Die evangeliese oorvertelling van die verhaal van Jesus mik nie op wettiese normering of etiese indoktrinasie nie, maar wel animasie, in dié sin dat dit die hoorder vanuit die meesterverhaal van Jesus wil konfronteer met, en uitnooi tot die lewe wat daar in Jesus is. Om die evangelie oor te vertel, is om mense uit hulle eie en ander bose geskiedenisse uit "los te praat", en in die goeie geskiedenis(se) van die evangelie "in te voer". Dis hier waar die prediker die kuns moet leer om op 'n verbeeldingryke wyse beilvolle beelde en verbale in die prediking te gebruik, beelde en verhale wat die teologiese kern van die Bybelteks honoreer en op 'n eietydse manier verder voer (vir 'n bespreking van verbeeldingryke prediking, vgl. hoofstuk 6).

\subsubsection{5 ...uit die mond van 'n méns...}

Die meesterverhaal van Jesus moet deur die hart van die prediker self gaan, voordat hy of sy dit kan oorvertel. In dié sin is die prediking 'n getuienis van die heil, aangesien die prediker nie 'n onpersoonlike "kanaal" is waardeur die vryspraak plaasvind nie, maar 'n mens wat self deur die evangelie van verlossing geráák is, wat dit self gló en die werking daarvan verwág. 'n Prediker moet 'n geloofwaardige getuie wees (vgl. verder hoofstuk 6 vir 'n bespreking van die rol van die prediker in die prediking).

Punt is: wie op die kansel verskyn, is nie 'n bloedlose wese nie, maar 'n mens met 'n geskiedenis, uit genade ook 'n beilsgeskiedenis, wat op een of ander manier wel tot uitdrukking in die prediking moet kom. Wat ons sê, moet ons glo. Die ink op ons preekpapiere moet bloed word. Dit beteken egter (juis!) nie dat die prediking nou mag opgaan in die private mening of persoonlike waardigheid of teologiese interesses of innerlike geloofwaardigheid van die prediker nie. Dit gaan in die eerste plek om die goeie nuus van 'n "objektiewe heilswaarheid", 'n gebeurtenis buite die mens om (extra nos). Hierdie heilswaarheid is egter op ons, op my gerig (pro me), en word in die prediking deur só 'n begenadigde mens verkondig.

\subsubsection{6 ...én die Gees.}

Dit bring ons by die sesde kenmerk van die prediking van verlossing: die Woord wat ons preek, is lewend deur die werking van die Heilige Gees. Kan ons dit genoeg herhaal? Dit bly die wonder van die prediking: die Gees gebruik ons stamelende woorde om God se Woord te verwoord. Hy self skep voortdurend in ons dié gebed: Here, gee ons tog $(u)$ woorde!

Dit mag wel die woord van die prediker wees wat sy of haar mond verlaat, maar deur die werking van die Gees is dit uiteindelik die Woord van 
God wat by die hoorders aankom. Miskotte formuleer treffend:"De prediking is een vurig ijveren en trachten ráak te schieten, tot eindelijk Gód de pijl richt, zijn Woord daar in bet hart, dat één brandende vraag was. Prediking is een open-houden der banden in bevende verwachting, dat God daarin vloeien doe bet levende Water om bet zo in diezelfde handen, zonder morsen, te dragen tot de gekwelde mensen. Prediken is woorden neerleggen als zovele toetsen, waaruit de Heilige Geest klinken doet het eeuwig lied van Gods Liefde." (1976:201)

Ja, die bladmusiek moet musiek word...

'n Mens kan beswaarlik die prediking ánders definieer as in terme van belydenisse en gebede. Die prediking is 'n brug en 'n pad, 'n deur en 'n venster, 'n kanaal en 'n pyp waardeur die Gees na ons toe kom (Luther). Die prediking is waar ' $n$ mens dit waag en dit God behaag (Barth). Die prediking is om verwonderd (oor) God se genade uit te roep, én dis 'n strydhandeling teen die magte (Wingren), ensovoorts...

Maar... wie van ons kan só preek?

'n Mens begin die gebed verstaan wat Spurgeon gebid het elke keer voordat hy op die kansel gegaan het:

O, Heilige Gees,

neem $U$ oor,

pas $U$ toe,

maak U lewend!

Hy of sy wat al gepreek het, sal weet dat jy nie sonder (so 'n) gebed op die kansel kan gaan nie. Enigeen wat al iets van die wonder ervaar het om te mag preek, sal onvermydelik voel dat hy of sy dit nog nooit gedoen het nie. Maar hulle sal aanhou probeer, aanhou hoop - tot hulle wel deur God se genade eendag, al is dit net één keer, wérklik sal préék...

Immers, die Gees is ook hiervoor aan ons gegee - sodat ons mag preek. Dìt maak ál die verskil. Dìt omskep die prediking in 'n hoopvolle handeling, 'n gebeurtenis waarin die hoopvolle beloftes van die evangelie deur die Gees van God sélf waargemaak word. Ja, hierin lê ons hoop: dat God self met ons handel en sal handel. Dat God ons nie afskryf nie. Dat die evangelie 'n krag tot verlossing is van elkeen wat glo (Rom. 1:16), 'n transformatiewe, blye Boodskap wat ook ons samelewings van die ontmensliking en die chaos kan red, en die moraliteit van ons wereld kan omvorm. Ons is nie alleen nie. Die Gees werk.

Dáárom mag ons - ten spyte van die kritiese stemme waarna ons in hoofstuk 1 geluister het - die evangelie van verlossing préék. 


\subsection{Die uitwysing van God op die kansel}

\subsubsection{KYK MOOI - WAT SIEN JY?}

Maar, dié evangelie moet só gepreek word, dat hoor uiteindelik ook sien word. Die teenwoordige God praat só met ons, dat ons Hom as die teenwoordige herken. Die ore wat die evangelie hoor, moet dus ook die oë word wat die teenwoordige God sien. Ons moet ons oë ook in ons ore sit (Luther). Maar, wat beteken dit? En, hoe gebeur dit? Voordat ons hierdie vrae probeer beantwoord - kom ons gaan besoek eers weer die kunsgalery! Kom ons laat toe dat die wêreld van die kuns ons 'n paar preeklesse leer...

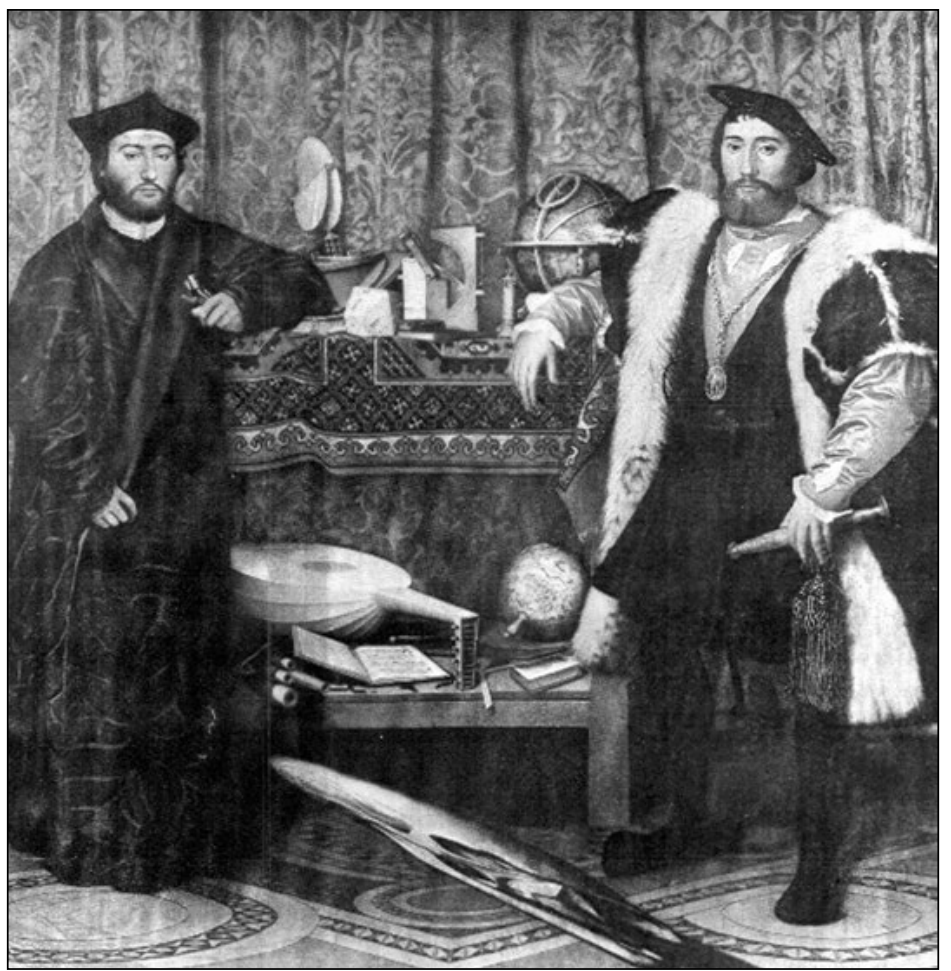

Teen een van die mure hang dit: Hans Holbein jnr. se boeiende skildery Die Ambassadeurs (1533). Hierin beeld hy twee welvarende en welopgevoede jong mans uit, albei Franse diplomate, genaamd Jean de Dinteville en Georges de Selve. Hulle word omring deur tipiese voorwerpe uit die tyd van die Renaissance: 'n aardbol, 'n fluit, 'n boek, 'n teleskoop en ander wetenskaplike instrumente. By hulle voete staan 'n lang, wit voor- 
werp - onidentifiseerbaar. Eers as 'n mens uit 'n sekere hoek na die skildery kyk - wanneer die voorwerp skuins of "skeel" gesien word - herken jy dit as... 'n menslike kopbeen.

Skielik word die welvarende en welopgevoede jong mans, asook die renaissance van menslike vermoëns wat hulle omring, in 'n meer komplekse, verganklike perspektief gesien. Die kopbeen sê: ook die jonges en die sterkes en die slimmes het 'n kopbeen by hulle voete. Ook hulle ontkom nie aan die suigkrag van die graf nie.

Die ironie van die skildery word nog verdiep deur die historiese feit dat die twee jong manne uiters begaafd was, maar tydens die posering vir die skildery reeds terminaal siek. Albei sterf op jeugdige ouderdom...

Enige goeie kunswerk doen presies dít: om ons aan die hand te lei na dié plek waar ons "skeel” kan kyk, om ons by die regte koördinaat te bring, om die lewe dus in 'n ander, verrassende - of ontnugterende - perspektief te plaas, 'n perspektief wat nie noodwendig waargeneem sou word as bloot gelet word op die vanselfsprekende en opsigtelike nie, as bloot van "voor" daarna gekyk word nie. Nee, daar moet diéper gekyk word, fyner opgelet word, om die werklikheid agter, of eerder: binne die "buitenste" en "alledaagse" oppervlak, raak te sien. (Goeie) kuns vra altyd van ons 'n nuwe waarnemersposisie, maar ook nuwe oë, 'n wedergeboorte van ons sinne, 'n wending in ons waarneming.

Sien gaan skep vooraf, én vloei hopelik daaruit voort. Om te kan skep, moet jy kan sien - anders kan jy ook nie ander láát sien nie. In hierdie "sienende skep" lê die begin en einde van die skeppingsproses en dus die sin daarvan. Kunstenaars kán eenvoudig nie daarsonder nie! Alle goeie literatuur - om nog een kunsvorm te noem - is deurdrenk daarvan. Dit word byvoorbeeld treffend uitgebeeld in die klassieke To Kill a Mockingbird van Harper Lee, waarin die leser die wêreld deur die helder kinderoë van die hoofkarakterjie Scout leer ken. In die slottoneel kyk sy self met nuwe oë na die bekende buurt waarin sy opgegroei het, "sien" sy skielik die dorp in seisoenale flitse, met beelde van die somer, herfs, winter en lente wat mekaar soos skyfies op 'n skerm voor haar geestesoog opvolg. In 'n kernsin van die boek verklaar sy:

"I turned to go home. Street lights winked down the street all the way to town. I had never seen our neighbourbood from this angle."

\subsubsection{SKREFIESOOG/OOPOOG DEUR DIE LEWE...}

Dít is wat kuns is: om die bekende (die "ou, ou tyding"!) uit 'n nuwe, "aweregse" hoek te sien - en dit só oor te vertel of oor te teken of andersins oor te skep dat ander dit ook uit hierdie nuwe hoek kan sien. Dis om 
soos Robin Williams as die onortodokse onderwyser in die rolprent Dead Poet's Society te maak: om voor die oë van die verbaasde kinders bo-op die tafel te gaan staan en te vra: Wat maak ek nou? As een van hulle antwoord: jy probeer groter wees as wat jy is, korrigeer hy: ek bekyk dinge vanuit 'n ander perspektief. Hier van bo af lyk alles anders! Dan doen hy die ongehoorde ding, totaal uit pas met die stramme en muwwe tradisies van die skool - hy laat die kinders twee-twee ook op die tafel klim om sy "les" tuis te bring!

Wie wil skep, moet van "bo" af na dinge kyk, of van "onder" af, moet ten minste met skrefiesoë op die fyn dinge van die lewe let, én met oopgesperde oё, om soveel as wat moontlik is in te neem, blinkoog soos 'n kind. Goeie kunstenaars word normaalweg met sulke skrefies/oopgesperde oë gebore. Wat Morley Callaghan oor skrywers sê, geld ook ander kunsvorme:

"There is only one trait that marks the writer. He is always watching. It's a kind of trick of mind and he is born with it."

Met "sien" bedoel ek natuurlik hier meer as net 'n biologiese sien. Van die beste "sieners" wat ek ken, is trouens biologies blind! Met "sien" bedoel ek eerder die totale wyse waarop 'n mens die lewe waarneem, met al die "sintuie" waaroor jy beskik. Dis 'n waarneming waar ander nie (kan of wil) waarneem nie, 'n sensitiwiteit vir die alternatiewe, vir die skone, of die lelike, of die skone binne-in die lelike, 'n sensitiwiteit vir die lewe self; 'n openheid om die waarheid deur elke senuwee van jou liggaam en elke vesel van jou bestaan op te neem -

"All thinking begins with seeing; not necessarily through the eye, but with some basic formulations of sense perception, in the peculiar idiom of sight, bearing or touch, normally of all the senses together." (Suzanne K Langer 1980: 216)

Ek haal sonder verdere kommentaar aan:

"Of dit nou 'n sublieme ding is of 'n plassie melk wat op die tafel lê, dit kan vir jou 'n beeld wees van iets wat baie ingewikkelder is." (Sheila Cussons, in gesprek met die Volksblad, 21 Augustus 1979)

"But please, let me have plenty of detail. That's what counts in our business, tiny little details, like you had a broken shoelace on your left shoe, or a fly settled on the rim of your glass at lunch, or the man you were talking to had a broken front tooth." (Paivio 1971:442) 


\subsubsection{KYK MOOI - WIÉ SIEN JY?}

Die vraag is nou: Wat maak Christelike kuns, waaronder die prediking na my mening tuishoort, anders as kuns in die algemeen? Alle kuns is die proses en die vrug van waarneming. Wat neem die Christenkunstenaar en dus prediker waar? Die antwoord lui, oorvereenvoudig: God. In die prediking - in die geloof! - staan of val alles by die Visio Dei, die waarneming van (die onsienlike) God. Hiermee bedoel ek by uitstek nie 'n biologiese sien nie, want wie kan God sien en bly lewe? Daarom weier God ook dat ons Hom só sal sien (Vgl. Eks. 33:20). Dit handel om 'n geloofsvisie, waarvan ons sou kon sê: wie nie (so) sien nie, het niks om te sê nie, niks om oor te preek nie, niks om oor te getuig nie...

Die begrip "sien" word in 'n verskeidenheid nuanseringe in die Bybel gebruik, en is in die loop van die kerkgeskiedenis ook op verskillende maniere geïnterpreteer. In die Skrif neem dit soms die vorm van 'n visioen aan, met 'n gepaardgaande ekstatiese toestand, in die besonder by die $\mathrm{Ou}$ Testamentiese profete (vgl. Jes. 1; Eseg. 12, ens.). Dit lei egter altyd, ook in die Nuwe Testament, tot 'n nuwe openbaring van die waarheid (onderstreep deur 'n hoor van “onhoorbare” woorde), en 'n nuwe bewuswording van God se teenwoordigheid (vgl. Hand. 9 en 16). Die onderskeid tussen hierdie visioene en drome is vloeibaar, en dit handel gewoonlik oor albei onmiddellike situasies (vgl. Hand 12) én die vooruitsig op dit wat nog ver in die toekoms mag lê, maar aan die kom is (vgl. veral Daniël en Openbaring).

In die Evangelies verkry dit uiteraard ook die betekenis van 'n biologiese sien van Jesus tydens sy aardse optrede deur die dissipels, en ook ná sy opstanding. In talle van die verskyningsverhale word berig: "Ek het die Here gesien!" (Joh. 20:18) Veral Johannes span die begrip "sien" doelbewus in die opbou van sy evangelie in, en meestal op 'n dubbelsinnige wyse: daar is meer te sien as wat jy met die eerste oogopslag kan waarneem, meer as net byvoorbeeld brood of water of lig - dit het alles dieper dimensies en betekenisse. In feitlik elke hoofstuk van sy evangelie demonstreer Johannes dat kyk nie altyd insien is nie. Daarom kan die manier waarop jy "sien" vir jou óf verlossing óf oordeel beteken (vgl. 9:35-41). Dit geld veral die manier waarop jy na Jesus kyk. Op die oog af lyk Jesus van Nasaret soos 'n gewone mens. Maar kyk weer! Die dissipels het Hom met hulle (biologiese) oë gesien, en tog méér gesien. Hulle het sy heerlikheid gesien, die heerlikheid wat Hy, as die enigste Seun, van die Vader het, vol genade en waarheid (1:14; vgl. ook 1 Joh. 1:1-4). Hulle het sy "onheerlike heerlikheid" gesien!

Ek gebruik die begrip "sien" veral in laasgenoemde sin, as 'n sien-teendie-oënskynlike in, as 'n sien al sien jy die teendeel, as 'n sien van God in 
die paradoksale, as 'n oortuiging van die dinge wat ons nie (nou met ons biologiese oë) sien nie (Heb. 11:1). Dit is uiteraard ook iets anders as 'n mistieke vereniging met God, soos dikwels in die mistisisme beweer is. Dit handel hier eerder oor God wat Homself aan ons op 'n unieke wyse openbaar, sodat ons tot 'n nuwe siening kom van ons plek voor God, en ook tussen ons medemense.

Anders gestel: Christelike kuns en prediking het te make met die uitwysing en uitdrukking van die werklikheid van God in die alledaagse, met al die implikasies wat dít inhou. Die prediking moet ons by uitstek help om self die onsienlike God te sien (vgl. Heb.11:27). Dáárom is die prediker niks anders nie as 'n uitwyser van God op die kansel...

'n Aanhaling wat dít treffend illustreer, is die van Christoph Blumhardt, 'n Duitse leraar uit die vorige eeu, wat twee jaar voor sy dood in 'n aangrypende preek oor die saligsprekinge God op die volgende wyse uitgewys het:

"'n Mens kan op aarde God aanskou. Ek kyk elke dag in die wêreld om my heen, nie om gruweldade te sien nie, maar iets van die liewe God. En waarlik, orals waar jy kyk, in die bemel en op die aarde, in die gras en in die vrugtebome, orals, ook wanneer dit dikwels treurig en verskriklik is, orals is lig. Orals kan jy God aanskou... Ook wanneer jou lot uiterlik dikwels treurig daar uitsien, kyk tog 'n slag indringender daarna. Fy kan ook daarin iets van die heerlikheid van God, iets van die ewigheid self sien."

Orals is lig! Die lig skyn in die duisternis, die duisternis kon dit nie uitdoof nie! (Joh. 1:5) Vir God is selfs die duisternis nie donker nie, en die nag so lig soos die dag, duisternis so goed soos lig! (Ps. 139:12) Waarlik, as 'n mens dit sou wou wáág om die kern van die Bybelse verhaal in 'n paar woorde saam te vat, sou die antwoord iets van die volgende móés bevat: God is by ons. In 'n enkele Naam word ál die elemente van die drama tussen God en mens gebundel: Immanuel (Matt. 1:23). Alle oproepe tot bekering in die Bybel het in die eerste plek dít as grondtoon: maak tog net jou oë oop! Sien jy dit wat vasstaan? Of beter: sien jy die Een wat vóór jou staan?

\subsubsection{UITWISSING OF UITWYSING?}

Wat is die oorsprong van moralisme (wettisisme) anders as 'n verlies aan visie op God? (vgl. verder 3.7 vir preekvoorbeelde) Om God by wyse van spreke in preke uit te wis? In plaas daarvan dat mense se oë geopen word om die groot dade van God in die verlede, hede en toekoms raak te sien, word só oor God gepraat asof Hy nie dáár is nie, asof Hy nie dié (oor- 
spronklike en finale) Realiteit is nie. In wettisisme word mense se oë eerder op hulleself gerig. Is God eerder "afwesig", en moet sy handelinge deur mense se handelinge "geaktiveer" word. Maar, kán ons? Nee, predikers hoef God nie te skep nie. God skep óns. Ons hoef God nie lewend te kyk nie, maar (mag) kyk ómdat God lewe. Helaas, so dikwels kyk ons dít mis -

Earth's crammed with beaven

And every common bush afire with God;

But only be who sees, takes off his shoes;

The rest sit round it and pluck blackberries.

(Elizabeth Barrett Browning in “Aurora Leigh”)

Sien is die sin van skep, het ek vroeër gesê. In terme van die prediking sou dit lui: om God te sien, is die sin van preek, en wel om só te preek dat ook die hoorders iets van God kan sien; is om só na Hom te wys dat ander ook iets van Hom kan wysword. Wat deur hulle ore ingaan, moet hulle oë as 't ware van binne ontsluit. Die oor wat hoor, die oog wat sien - die Here het albei gemaak (Spreuke 20:12). Rudolf Bohren preek meevoerend hieroor:

"Fou boor en sien se oneindige waarde lê daarin dat dit van die ewige God af stam. Fy hoor met ore wat deur die Begronder van kontinente en oseane gemaak is. Fy sien met ö̈ wat deur die Here van die melkwegstelsels aan jou geskenk is... Die geskiedenis van die poësie en die musiek, die geskiedenis van die skilderkuns en die beeldkuns is net 'n eggo van die oneindige moontlikbede wat aan ons deur ons ö̈ en ore gegee is... Dit is deur bierdie oё en ore dat die Gees aan ons 'n nuwe waarnemingsvermoë skenk, 'n vermoё wat tegelykertyd die grense van hierdie ö̈ en ore oorskry." (1981: 7173)

Dít maak van die prediking by uitstek 'n avontuur, waarin ons elke dag met ons skrefies/oopgerekte oë kan vra: waar is God aan die werk? 'n Ontdekkingstog, waarin ons elke dag die leidrade wat God ons laat, mag vind en opvolg, waarin ons in sy voetspore mag loop, voetspore wat nie net kruis en dwars in die heilige katedrale lê nie, maar ook in ons werks- en woonplek, deur die kombuis en die kantoor, ja, op die skynbaar vervelige paadjies en deur die donker dieptes van ons elkedagse bestaan.

Dít is wat die prediking is: om skrefiesoog/oopoog in die voetspore van die werklike God deur die werklikheid te loop - en só te loop dat ander ook wil saamloop, en só te wys dat ander ook kan wysword. Dis om te wys en te sê: jy is omsluit van alle kante - deur God! (Psalm 139:5) Trouens, het die prediking iets anders te sê as dít? 


\subsubsection{EN AS EK NOU NIÉ SIEN NIE?}

In die prediking handel dit om die sien en die uitwys van Hom wat ís, om 'n dieper kyk as die oppervlak, om die teenwoordigheid van God ín ons werklikheid te onderskei. Maar wat nou as jy (diep) kyk en kyk... en jy bly níks sien nie? Dis immers óók 'n (geloofs)ervaring waarvan die Bybel vol is: die nie-sien-nie van God, die worsteling met sy swye en afwesigheid, die versugting: My God, my God, waarom het $U$ my verlaat? (Psalm 22:2; Hab. 1:13; Psalm 42:2; Mark 15:34, ensovoorts)

Gelowiges gaan óók soms deur 'n woestyn- en winterervaring, wanneer alles om en in hulle die goeie nuus van die Immanuel, van God by ons, geheel en al weerspreek. Daar kom sulke tydperke nie alleen in individuele gelowiges se lewens nie, maar ook in die geskiedenis van die kerk of 'n spesifieke kerk, wanneer hulle die ervaring het dat God ver weg staan, dat Hy sy volk vergeet het, dat Hy anderpad kyk (vgl. Psalm 13:1-3). Erger nog, wanneer hulle die ervaring het dat dit die Here sélf is wat hulle in die ellende gestort het! (Vgl. die refrein $U$ bet... U laat... U verstoot... U toorn rus op my in byvoorbeeld Psalm 88).

Dis dán wat jy nie alleen diep moet kyk nie, maar ook ver - God se toekoms in. Dan leef jy nie alleen uit die werklikheid van die Teenwoordige nie, maar in 'n besondere sin ook uit die werklikheid van die Komende. Dan is net die beloftes van God vir jou genoeg, al bly die vervulling daarvan nog vir jou uit. Dan bid jy saam met Sören Kierkegaard:

"Vader in die hemel! U praat op baie maniere met' $n$ mens: $U$ aan wie alle wysheid en verstand behoort, $U$ wil $U$ self so opnuut aan ons verstaanbaar maak. Ag, en ook wanneer $U$ swyg, dan praat $U$ tog wel met ons; want ook Hy wat praat swyg soms om sy leerlinge geleentheid te gee om bulle sê te sê; ook Hy wat praat swyg soms om sy geliefdes te beproef; ook Hy wat praat swyg soms om die oomblik van verstaan soveel inniger te maak wanneer dit kom. Vader in die bemel, is dit nie so nie? $O$, die tyd van die swye, wanneer 'n mens alleen staan en verlate, omdat ons U stem nie hoor nie, dan is dit vir ons asof die skeiding vir altyd sal duur. $O$, die tyd van die swye, wanneer 'n mens versmag in die woestyn, omdat ons $U$ stem nie hoor nie, en dit vir ons voel asof ons geheel en al vergete is! Vader in die hemel, dan is dit tog maar net 'n kort verposing in die samehang van die tweegesprek tussen $U$ en ons. So laat ook dit geseënd wees, hierdie swye van $U$, soos elke woord van $U$ aan ons. Laat ons nie vergeet nie dat $U$ ook dán praat, wanneer $U$ swyg; skenk aan ons hierdie troos: dat $U$ uit liefde swyg, soos $U$ ook uit liefde praat, sodat nou, of $U$ swyg en of $U$ praat, $U$ nog dieselfde Vader $i$, wat met dieselfde Vaderlikheid optree, of $U$ nou deur $U$ stem ons lei, en of U nou deur U swye ons opvoed." 
Dan vind jy troos daarin om soos die ry van geloofsvoorbeelde in Heb. 11 net maar uit die verte te sien, maar nogtans daarin te juig - want, immers, jy sien ten minste die toekoms. Nou sien jy nog niks nie - want, wat 'n mens al sien, hoop jy tog nie meer nie. Wie hoop nog op wat hy reeds sien? Maar as ons hoop op wat ons nie sien nie, wag ons daarop met volharding (Rom. 8:24,25). Dan moet jy maar die hede langs die omweg van die toekoms sien (Okke Jager). Maar dis al genoeg...

\subsubsection{EN WÉÉR 'N KEER: WIÉ SIEN JY?}

Buitendien, miskien sien ons God nie in die hede nie, omdat ons op die verkeerde plekke bly kyk.

Wie God sien, sien ook die medemens in 'n nuwe lig. En omgekeerd: wie die medemens werklik rááksien, sien ook weer vir God in 'n nuwe lig!

Soos die man op die Franse platteland wat tydens die oorlog 'n behoefte gehad het om kerk toe te gaan, om tog te midde van al die ellende net weer iéts van God te sien. Hy het die kerk ingestap gekom en gesien dat die binnekant daarvan in 'n hospitaal omskep is: die nagmaalstafel was 'n operasietafel, die doopvont 'n houer vir die inspuitings, die kerkbanke hospitaalbeddens vir dié wat gewag het op operasies of herstel het daarvan... Toe, in 'n vonk van insig, hét hy iets van God gesien, iets van die liggaam van die Gekruisigde, maar ook iets van die nabyheid van dié Gekruisigde aan ander, deur middel van ander...

Die prediking bestaan daarom ook daarin dat jy mense, ja, dat jy die hele spektrum van menswees, van blydskap en voorspoed tot by onsekerheid, skuld en die dood, teen die agtergrond, teen die horison van die Immanuel, wat ook die Komende is, sal sien en interpreteer. Dis om werklike, lewende mense in hulle samehang met die werklike, lewende God te sien - selfs al sou hulle daardie samehang nie self verstaan of toegee nie (vgl. Bohren 1981:8889). Martin Luther preek treffend oor ons dikwels misplaaste blikrigting:

"Die wêreld is vol van God. In alle stegies, voor jou deur, vind jy vir Christus. Moenie na die bemel gaan en sê: 'Ag, as ek onse Here en God tog net kon sién, boe sou ek Hom nie alle moontlike dienste bewys nie?' 'As jy My wil dien,' sê die Here, 'moenie onder die engele na My gaan soek nie. Ek sal in jou buis kom, jy sal My honger en behoeftig sien, maak net jou ö̈ oop. As jy My wil liefhê, betoon liefde aan jou naaste.' Ja, ons soek Hom waar Hy nie te vinde is nie. Hy bet uit die bemel neergedaal... maar ons wil daarbeen opstyg!"

Net soos goeie kuns, is die prediking ook maatskappykrities - dit kán nie, mág nie aan die bloeiendes in die oorlogshospitale of die hongeriges in die stegies en voor die deure van die rykes verbygaan nie. Dit móét krities 
wees teenoor 'n samelewing wat sulke mense nie (wil) raaksien nie. Wie God in die oog (wil) kry, sal gebroke en lydende mense ook in die oog (moet) kry (vgl. verder hieroor hoofstuk 5).

Prediking, soos kuns, wat net altyd "mooi" prentjies van die lewe teken, het nog nie diep genoeg na die lewe gekyk nie. Die evangelie is nie net "mooi" nie, maar dit praat ook van selfverloëning en kruisdra, van offerandes en voetewas, midde-in 'n wêreld wat gekenmerk word deur hongersnood en oorlog, lemmetjiesdraad en gasmaskers, AK-47's en kindermoord, ja, 'n wêreld waarin daar dae soos 11 Sept 2001 aanbreek...

"Om God te sien" is daarom nie 'n sensasionalistiese of triomfalistiese uitstyg bo die werklikheid nie - hoewel dit jou maklik tot op die rand van die kettery van triomfalisme kan bring! Triomfalisme is egter juis 'n kettery omdat dit nie so aards soos die evangelie is nie, omdat dit aan die kruis van Christus verbygaan, waar daar juis tot die dood toe geworstel word met die aardse, met die nood en die dood wat nou nog ons lewe op hierdie aarde kenmerk. Wie "visionêr" wil preek, sal aan die voet van die kruis móét bly, sal inderdaad niks anders as Christus mag verkondig nie...

Prediking wat voorgee om God te sien, mag daarom nie onbewoonbare visies aan die gemeente voorhou nie, maar bewoonbare visies, waarin mense van vlees en bloed, mense wat hulle nog in hierdie bedeling bevind, kan tuiskom. Visionêre prediking is nie vergesog nie, maar open vergesigte wat wel vergesog mag wees, vanuit die verte gesien en na gehunker kan word, maar wat haalbaar is, omdat jy weet dat jy daarheen gebring sál word.

Dat ek God moet (kan) raaksien en uitwys in die prediking beteken gelukkig nie dat ek staal in my oë moet hê nie, eerder 'n gebroke blik; dat ek soms maar my kop kan laat hang. Trouens, dis juis mense wat hulle kop laat hang wat dit beter as ander regkry om "skeel" te kyk, wat makliker die geheimenisse van die koninkryk van God kan raaksien, wat hulle makliker daaroor kan verootmoedig én verwonder.

Buitendien, wie die kop laat hang om "skeel" te kyk, vind dit ook makliker om die hoof te buig - in gebed. Hierdie styl van gebed moet die prediking en die erediens - die hele lewe - van begin tot einde deurdring. Want, om God te sien is nie 'n vanselfsprekende gebeure of permanente toestand nie. Ek moet elke oggend nuwe oë kry. Sodat ek opnuut uit genade my kan verwonder en vreugde kan vind in die ontdekking en sien van God, en ek Hóm op die kansel kan uitwys...

Waar ek vroeër gesê het dat sien skep voorafgaan én opvolg, moet ek dit nou kwalifiseer: voordat jy kan sien en preek, moet jy so (bly) bid, soos Paulus sê: dat jou geestesoë verhelder kan word... (Efes.1:18; vgl. hoofstuk 6).

Ek herhaal: wie visionêr wil preek, sal aan die voet van die kruis moet bly. Ek reken dis weer tyd vir 'n besoek aan die kunsgalery. Kom ons kyk vir 'n oomblik na byvoorbeeld Antonello Da Messina se Die Kruisiging. Daar hang die 
Gekruisigde, en, as jy mooi kyk, by sy voete is ook, soos in Hans Holbein jnr. se Die Ambassadeurs, 'n kopbeen, trouens, 'n hele aantal kopbene. Ook Jesus ontkom blykbaar nie aan die krag van die kopbeen nie. Maar kyk mooi. Trek jou oë skrefies. Sper hulle wyd oop. Sien jy dit? Die kruis is nie net teken van die dood nie, maar ook teken van die lewe. Die kopbene 'n herinnering daaraan dat hierdie Gekruisigde se kopbeen nóóit in 'n graf bleek sou word nie. Die kopbene sterf saam met Hom, want die dood is oorwin...

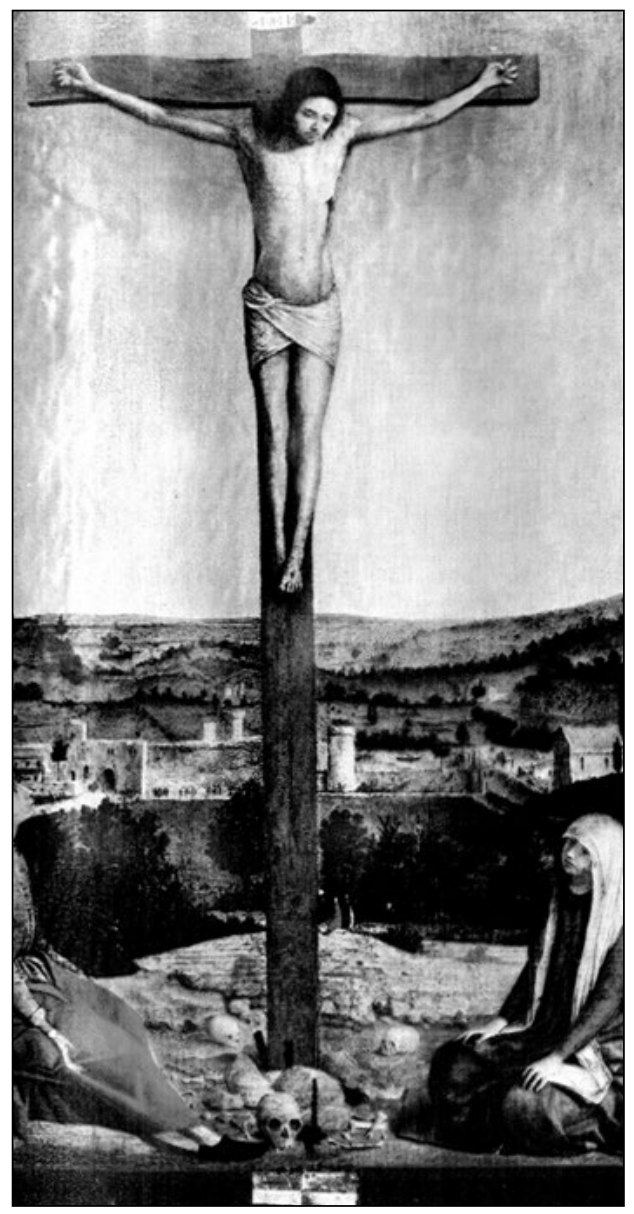

Voordat jy die kopbeen van verganklikheid by jou eie voete kan raaksien, het jy 'n perspektiefwisseling nodig. Maar ook omgekeerd: voordat jy verder as hierdie kopbeen kan kyk en die lewe, die onverganklikheid kan raaksien, het jy 'n verdere perspektiefwisseling nodig, 'n perspektiefwisseling wat alleen by die Kopbeenkoppie, by die plek van die Skedel, dit wil 
sê by die teenwoordige-God-selfs-tot-in-die-dood te vinde is. Alleen dáár vind jy die regte koördinaat van waar jy die lewe - die opstanding - kan raaksien. Alleen dáár, by hierdie kruispunt, kan jy drie dae verder, ja, 'n ewigheid verder kyk, na die plek waar daar nooit weer kopbene te siene sal wees nie omdat die dood nie meer daar sal wees nie (Open. 21:4).

Wie hierdie koördinaat gevind het, ja, wie na hierdie koordinaat gebríng is, kan begin om die evangelie te preek.

\subsection{Die uiwissing van God op die kansel ${ }^{14}$}

Die hartseer realiteit is egter dat talle predikers juis nié hierdie evangelie van verlossing preek nie - al verkeer hulle dikwels onder die indruk dat hulle dit wél doen. Hulle verander die evangelie in 'n moraal, oftewel in 'n moralistiese oproep tot selfverbetering. Wat is moralisme? Kortweg gesê: dit trek'n streep deur al die uitgangspunte wat tot dusver na vore gebring is. Die teenwoordigheid van God, sy spreke met ons, die feit dat dit 'n verlossende spreke is, word trouens - soos ek reeds in 3.6.4 aangedui het - presies omgekeer: in moralisme moet ons God as 't ware teenwoordig stel, sy Woord aktiveer, self die verlossing bewerkstellig. Dit klink na 'n harde oordeel, maar die talle voorbeelde wat hier volg, mag iets hiervan illustreer.

14 Ek doen die volgende preekanalises, asook dié in die hoofstukke wat volg, vanuit spesifieke (Gereformeerde) uitgangspunte in verband met die verhouding tussen wet en evangelie, en daarom ook tussen sonde, verlossing en dankbaarheid. Dit behels onder meer die volgende:

God se Woord aan ons vorm 'n eenheid, is 'n onverdeelbare openbaring van Homself aan die mens, waarin die eer van begin tot einde aan niemand anders toekom nie as aan Homself. En die doelwit van hierdie één Woord van God aan ons? Dat ons sal verander. Sal word wat God wil hê ons moet wees: Christene, en daarom waarlik ménse, Gód se mense.

Wel is daar binne hierdie enkelvoudige Openbaringswoord van God verskillende gestaltes, en sien ons daarin 'n verskeidenheid van God se gesigte, maar dit bly steeds dieselfde God wat só met ons handel dat ons daadwerklik nuwe mense wórd.

Die omsluitende sirkel bly altyd God se een Openbaringswoord aan ons. Hierdie Woord is daad tegelyk. Dit kom daad-kragtig tot ons deur die werking van die Heilige Gees. Maar dit kom tot ons op 'n verskeidenheid van maniere. Die Openbaringswoord kom primêr na ons as verlossingswoord om ons vry te spreek van die sonde wat God self deur sy wet aan ons geopenbaar het. Dit kom egter ook na ons as wet wat ons sonde blootlê (die sg. eerste funksie van die wet), en ons so uitdryf na Christus toe (die tweede funksie van die wet, ook usus elenchticus of usus paedagogicus genoem, en as dit oor meer as net persoonlike sonde, maar ook oor samelewingsondes handel, usus politicus). Dit kom ook na ons as riglyn vir 'n lewe van gehoorsaambeid aan God, wat die Here self uit genade deur sy Openbaringswoord in ons bewerkstellig (die derde funksie van die wet, ook usus tertius genoem). 
Die taalstruktuur wat die mees algemene aanduiding van moralisme is, is voorwaardelike sinskonstruksies. Sulke voorwaardelike konstruksies is, linguisties gesproke, uitdrukkinge van 'n meer omvattende verskynsel, naamlik dié van konjunktiewe spraakvorme. In hierdie spraakvorme word oor werklikhede as moontlikhede gepraat, word moontlikhede in die plek van werklikhede gepostuleer in die vorm van die irrealis (die sogenaamde conjunctivus irrealis). Indien op hierdie manier oor die heilswerklikheid (God se teenwoordigheid en verlossende spreke) gepraat word, is die implikasie dat God in 'n postulaat verander word, 'n Moontlikheid wat in irreële, voorwaardelike terme uitgedruk word - en slegs deur die handelinge van mense "geaktiveer" kan word.

In 'n preek oor die aangrypende proloog van die Johannesevangelie ( 1:118 ) word hierdie grammatikale en prinsipiële uitskakeling van God byvoorbeeld dramaties geillustreer. Die hele preek handel oor die vraag waarom Jesus dan nou "special" sou wees, en ten einde antwoorde op hierdie vraag te bied, word die Bybelteks eerstens geatomiseer (klein gedeeltes daaruit word uit hulle verband aangehaal) en tweedens gemoraliseer wanneer die prediker tien lesse daaruit haal om te bewys dat Jesus spesiaal is. In die proses word wonderlike en waar dinge oor Jesus gesê, maar word Hy ook skadeloos gestel, word Hy onder die voorwaarde van die handelinge van vroom mense tot passiwiteit gedwing, met die implikasie: eers as mense Jesus aangeneem het, dán kan sy lig skyn in die duisternis.

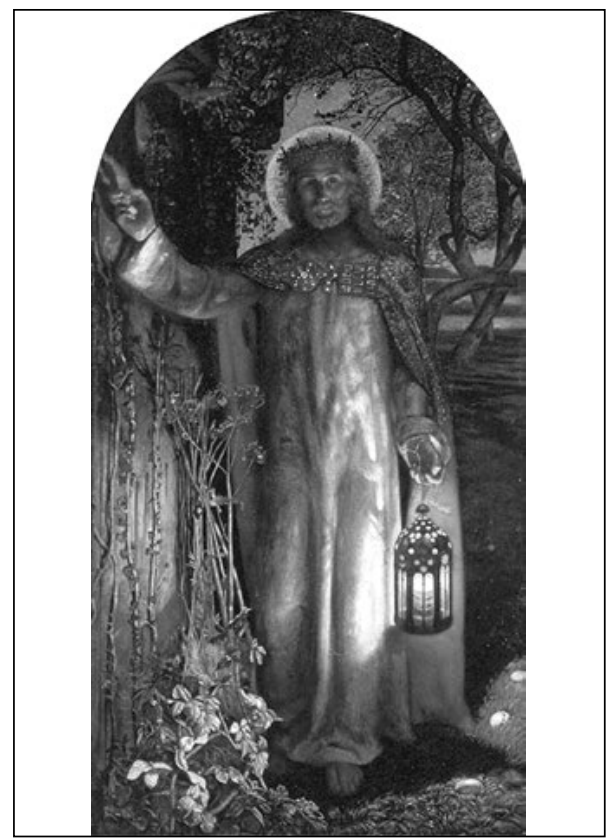


Die preek eindig met 'n mooi, maar teologies gesproke uiters verleidelike beeld, wanneer Jesus geskets word as Een wat buite die deur van 'n huis staan met 'n lampie in sy hand, 'n deur wat baie lank nie oopgemaak is nie - dis feitlik al toegegroei. Jesus staan en Hy klop - 'n sinspeling op Openbaring 3:20 - maar niemand maak oop nie. Die deur het net een handvatsel en dit is aan die binnekant. Jesus kán dit nie van buite af oopmaak nie. -

“...I want to remind you - the bandle is on the inside. It's on your side of the door. And Jesus is the perfect gentleman. He never forces His way in. He waits for you to acknowledge that you need Him. He waits for you to put your band out and grab bold of the bandle and open the door and say: "Come into my life, Lord Jesus." I want to ask you this morning in the light of what we've been hearing, don't you want to do just that?"

Jesus is wonderlik, "special”, maar skadeloos. Met sy lampie staan Hy daar buite, sonder raad en sonder mag. Hy wil graag sy lig in die donkerte laat inbreek, maar Hy kan nie. Die handelende, herskeppende God van die Johannesproloog, dié Een wat nie net die wêreld wil red nie, maar sy lig daadwerklik in die duisternis laat skyn, word 'n statiese God, 'n stilstaande Moontlikheid.

"He waits for you...He waits for you", sê die prediker. Die teks wat hy aangegee het as sy preekteks lui: Die lig skyn in die duisternis, die duisternis kon dit nie uitdoof nie. (Joh.1:5) In die preek doen 'n vroom prediker en vroom mense juis dit - hulle doof sy lig uit! Of laat Hom ten minste met sy flou lampie buite in die triestigheid staan...

Die blote teenwoordigheid van Christologiese titels en formules, waarvan daar 'n oorvloed uit die dogmageskiedenis beskikbaar is, beteken nie noodwendig dat die prediker die inhoud daarvan werklik verstáán nie. Trouens, dikwels is sulke titels en formules - indien hulle gemeet word in die lig van hulle historiese oorspronge - totaal uit pas met dit wat in werklikheid in die preek gebeur, duik hulle op óf as cliche's, óf as vreemde liggame in die struktuur van die preek. Meermale word sulke titels en formules van hulle inhoud en krag beroof. Dit dui dikwels op predikers se verleentheid om die wonder van die verlossing in Christus nuut en tydig uit te druk - daarom word daar eerder teruggevlug in 'n vroom verlede, in begrippe wat die prediker self nie meer verstaan nie, maar wat reg klink en aan die prediker 'n geruste gewete moet verskaf. Dogmaties-historiese korrektheid beteken nie noodwendig evangeliese waarheid nie. Die evangelie kom nie in formules nie, maar in krag. 


\subsection{1 'N SUBSTITUUT VIR GOD?}

Dat predikers Christologiese formules en titels kan aanhaal sonder om die evangeliese kwaliteit daarvan te ontgin, is in talle preke duidelik. Dit geld ook die gebruik van ander Godsbeelde, -name en -predikate. Op die oog af lyk dit korrek, maar indien sekere sleutelsinne in die preke ontleed word, blyk dit dat God in werklikheid metodologies én sintakties uitgesluit word. Op 'n verskeidenheid van wyses, wat egter almal bogenoemde voorwaardelike trek insluit, word God gemuilband en vervang. Die mees algemene substituut is die homo religiosus, oftewel godsdienstige mens.

'n Voorbeeld: 'n mens kan op só 'n wyse besig wees met "geestelike oorlogsvoering" dat die méns in die sentrum staan, en nie God nie. Só stry teen die bose asof God nié die Oorwinnaar is nie...

'n Definisie van "strydgebed" soos die volgende laat jou wonder wie nou uiteindelik die oorwinnaar is - Christus of die bidder? -

"Om (onophoudelik) die voltooide werk van Christus oor die magte van die bose in bul aanvalle op 'n plek of persoon af te dwing, totdat die oorwinning behaal is..."

Af te dwing? Die implikasie is tog: Christus se werk is voltooi, maar dit reik nie ver genoeg nie. Ek, die bidder moet dit afdwing, aktiveer, in werking stel oor die bose - todat die oorwinning behaal is! Wel, dit ís so, ons hét 'n stryd om te stry (vgl. Efes. 6) Net maar, die stryd wat ons moet stry (militia Christiana) is om te bly binne Christus se oorwinning. Feit is: die slag is reeds geslaan. Die Bose ìs oorwin. Ons is wél nog in 'n stryd teen hom gewikkel (militia), maar dis 'n stryd van méér as oorwinnaars (Christiana).

Uitsprake soos die volgende is ten diepste nie net onteologies nie, maar - ten spyte van die goeie bedoelings daarmee - Godonterend, in dié sin dat dit die eer van God wegneem:

"Niks gebeur in die koninkryk van God as daar nie êrens eers gebid is nie."

Werklik? Niks? Is God dan passief totdat ons Hom deur ons gebede uiteindelik sover kry om tog iets te laat gebeur? Nee, God neem - in sy vooraf-genade (vgl 3.5.1.2) - tog die inisiatief, ook wanneer ons bid: Ek het my wil geopenbaar aan 'n volk wat nie na my wil gevra bet nie. Ek bet My laat vind deur mense wat My nie in die gebed gesoek het nie. Vir 'n nasie wat My nie aangeroep het nie, het Ek gesê: Hier is Ek! Hier is Ek! (Jes. 65:1). Presies dít is die evangelie!

'n Mens sukkel egter om dié evangelie te hoor wanneer die volgende vraag en antwoord jou met die onmoontlike belas: 
"Waarom bid? Om God se krag in werking te stel."

Nee, gebed aktiveer nie God se krag nie. Die Here sluimer en slaap nie. Hoogstens aktiveer dit óns. Deur God se genadige aksie ín ons.

Uitsprake soos hierdie is, behalwe vir die feit dat dit misleidend is (ons dink dat ons tot dinge in staat is waartoe ons nié is nie) ook net op die oog af opwindend. Uiteindelik stort dit jou in swaarmoedigheid of in doodgewone verveling. Niks kan die "opwinding" van die verrassende evangelie van genade vervang nie! 'n Evangelie wat sê dat God sélf sy Woord uit genade waarmaak...

Só word in talle preke hierdie waarmaking van die preek deur God self letterlik (in terme van die taal!) uit sy hande geneem. Sy handeling (soos wat die Bybelse teks dit uitspreek), word nie verder uitgespreek sodat mense op grond daarvan kan handel nie, maar eerder omgedraai en nou afhanklik gemaak van mense se handelinge. Daar vind 'n antroposentiese omslag plaas: dis nie meer God wat deur sy handeling 'n situasie skep nie, maar eerder mense wat'n situasie moet herskep ten einde God te laat handel. 'n Mens hoor hierdie omdraaiproses byvoorbeeld duidelik in 'n sin soos die volgende:

"Tog is fesus se opdrag dat ons in alle omstandighede mekaar tog moet liefhê. Dan eers beskou Hy ons as sy dissipels, sy navolgers."

Wie op aarde kwalifiseer om 'n dissipel van Jesus te wees?

\subsubsection{DiE BASIESE STRUKTUUR VAN WETTISISME}

Wettiese spraak klink meestal korrek, maar dit het geen Inhoud nie. Dit kan retories gesproke meevoerend wees, en tog is dit religieuse bla-bla. Dit bly leë spraak, want dit spreek nie God se werklikheid en werksaamheid hier en nou uit nie. In wettiese preke word verklaar wat God gedoen het, moontlik wéér sal doen, en wat mense moet doen om God weer te laat doen wat Hy gedoen het. Kortweg gesê, sou 'n mens die basiese struktuur van alle wettiese preke trouens só kon saamvat:

- God het (in die verlede);

- God sal of wil (in die toekoms);

- Ons moet (in die bede).

Ten diepste is die uitgangspunt van alle wettiese preke God se afwesigheid in die hede, en moet dié vakuum gevul word met die vroom ywer van die bomo intactus (ongebroke mens). Die wonder van die praesentia realis dei 
(die werklike teenwoordigheid van God) word oorwoeker en uitgeskakel deur die modus van die subjunctivus irrealis.

'n Klassieke voorbeeld van bogenoemde basiese struktuur van wettisisme sien 'n mens in 'n preek oor Josua 3:1-17, waarin Israel op die punt staan om die Jordaanrivier oor te steek. Die prediker vind in dié geskiedenis 'n parallel met Suid-Afika wat 'n onseker toekoms in die oë staar, 'n toekoms waarin eiendom, politieke mag, die waarborge van werksgeleenthede en die vooruitgang van besighede bedreig word. Teen die agtergrond van hierdie onseker tye word die gemeente opgeroep om op God te vertrou, Hom te erken en aan te neem - aangesien die gemeente, net soos die geval was met Israel wat oor die Jordaan moes trek, behoefte het aan God se "divine intervention".

Met behulp van aanhalings uit die Hebreërbrief sowel as uit die boek Josua onderstreep die prediker op 'n retories voortreflike manier "the miraculous working power of God amongst the people of Israel", en beklemtoon hy: "God cares...rescues...sets them on a new path". Wat God in die (resente) verlede in Suid-Afrika gedoen het (met die eerste algemene verkiesing in April 1994), word dan as nóg 'n voorbeeld van sy wonderwerkende inisiatief aangevoer.

Dis sover dit die verlede betref. Wanneer die prediker egter na die bede kyk, en met die hoorders wat nou leef, begin praat, verander die hele toonaard van die preek. Dié veranderde toonaard blyk byvoorbeeld uit die sleutelsin:

"God wants to encourage faith in us so that we might trust Him. He wants us to embrace his Lordship".

Nou is daar slegs sprake van God se "intent", slegs 'n moontlikheid van dinge wat kán gebeur.

Waarom hierdie skielike verandering van tydsvorm? Dit vind heelwaarskynlik plaas omdat die prediker sy hoorders wil voorberei vir die tweede gedeelte van sy preek, waarin hy dit wat hy tot dusver gesê het wil "toepas" op mense wat in onseker tye leef en 'n onseker toekoms tegemoetgaan. Daarom die breuk en kontras, uitgedruk in die woordjie "But". Die tweede gedeelte van die preek word ingelui met die sleutelsin:

\section{"But what does the fordan story have to say to us this morning?"}

"But" vorm die brug tussen God se historiese dade en sy toekomstige bedoelings, druk die spanning uit tussen wat God gedoen het in SuidAfrika en wat Hy nog in die tyd van oorgang wil doen.

Die tweede gedeelte van die preek leun inderdaad sterk oor na die toekomstige, en beklemtoon moontlikhede. 
Miskien illustreer die volgende sinne dié spanning tussen heilsgeskiedenis en heilsmoontlikheid die beste. Eers kyk die prediker na die Bybelteks en sê:

\section{"Friends, Joshua was not afraid because God went before him."}

Dan wend hy hom tot die gemeente en verklaar:

"How are you crossing your fordan today? Is it alone? Is it on your own strength?

God wants to go before you. God wants to lead you. God wants to help you." Met respek gesê: God word op bystand geplaas. Hy moet staan en wag. Hy wil graag handel, maar doen dit nie. Waarom? Omdat iets eers moet gebeur, sekere voorwaardes eers vervul moet word. Maar wat?

Die hoorder moet eers handel. Tussen God se dade in die verlede en sy dade in die toekoms staan die dade van die gemeente in die hede. Daarom is dit heel konsekwent as die prediker voortgaan en sê:

"The fordan story tells us what we must do."

Nou val die nadruk nie meer op wat God volgens die Jordaanverhaal gedoen het nie, maar op wat die hoorders moet doen. Terwyl die eerste gedeelte van die preek oorheers word deur teenswoordige, indikatiewe taalstrukture, en die tweede deur toekomstige en irreële, word die derde gedeelte hoofsaaklik gestruktureer deur imperatiewe. Herhaaldelik hoor ons: "...you must...we must...we must...you must".

Die prediker interpreteer, al is dit onbewus, die hede as 'n vakuum tussen God se dade en God se moontlikhede. Hierdie vakuum word betree deur die ongebroke homo religiosus, wat deur sy en haar keuses die toekoms - dit wat God wil doen - laat uitsien soos die verlede - dit wat God gedoen het. Mense moet in die hede die toekoms soos die verlede laat lyk. In werklikheid word die hede daardeur van God se handeling gestroop.

Die wyse waarop die prediker in die wettiese slaggat trap, blyk dramaties en gekonsentreerd in 'n aantal sinne waarin onder meer ook die eerste gedeelte van die Bybelteks, Josua 3:5, aangehaal word:

"You must consecrate yourself to God"

Die toevoeging of uitleg wat hierop volg, lê egter die wesenlike uitgangspunte van die preek bloot:

"What happens when you consecrate yourself to God? The Lord will do amazing things among you. So you see, my friends, when you commit your life to God that's precisely what you will see." 
Die Bybelteks - Josua 3:5 - sê juis dit nié. Dit lui eerder as volg: Purify yourselves, because tomorrow the Lord will perform miracles among you. (GNB) - Reinig julle, want môre gaan die Here wonders doen tussen julle. Wat in die Bybelteks want (because) heet, word in die preek wanneer (when). Die volgorde van die Bybelteks word presies omgekeer. Die rede of grond van die oproep tot heiliging verword in die preek tot die uitvloeisel of gevolg van die heiliging. Daartussen lê natuurlik 'n reuseverskil. In sy ywer om dit wat hy as 'n vakuum tussen verlede en hede ervaar, te vul, verander die prediker die optrede en situasie van die Israeliete wat in die Bybelteks die veronderstelling vir die verkondiging van God se groot dade was. Dit word nou die voorwaarde wat die huidige gemeente moet vervul om die groot dade weer waar te maak. Die reaksie van Israel, wat in die Bybelteks geprekondisioneer is, word in die preek ' $n$ kondisionerende handeling; die bepaalde situasie word 'n bepalende situasie. Tussen die hand (die Bybelteks) en die mond (die preek) val die pap (die evangelie) op die grond. Dit het ingrypende gevolge. God se handelinge hang nou daarvan af of, en in watter mate, ons onsself kan reinig, en dit ook nog "most completely". Maar, moet ons onsself geheel en al reinig voordat God kan handel? Klink die evangelie werklik só?

\subsubsection{MORALISME EN GODSBEELD}

Predikers moet veral versigtig wees in hulle keuse van beelde wat bulle ten opsigte van God in hulle preke gebruik. Dit verraai dikwels 'n onderliggende Godsbeeld, en ek hou slegs een voorbeeld as afskrikmiddel voor. Dit kom uit 'n preek oor Jesaja 1:16-18, waarin die prediker God sowaar vergelyk met... wel, lees maar self:

"Het jy miskien vanoggend in al die woede en haat die skoonbeid van die wêreld misgekyk? Dit laat my dink aan die storie van die twee donkies. Hierdie donkies was aan beide ente van 'n tou vasgemaak. Nou, net buite bereik van die donkies is twee hope wortels. Soos donkies is, trek bulle teen mekaar om by die wortels te kom. Al wat bulle so bereik, is moegheid. Toe albei baie moeg was, sit bulle by mekaar en besluit bulle om eers saam na die een hopie te gaan en dan na die ander. Ons is net soos die donkies. Aan die een ent is ons en aan die ander ent is God. Met my beste vermoë probeer ek trek in die rigting van my eie self. Ek bly trek, later is ek so moeg dat ek op my knieë gaan van moegheid. Dit is wanneer God, wat op die ander ent van die tou is, na jou toe kom en sy hulp verleen. Dan gaan ons saam, eers na die een probleem, en dan na die ander."

God en die mens in tou-trekkende ewewig? God soos 'n moeë donkie? 
Terwyl die boek Jesaja juis gloei van die genadige inisiatief van God wat sy volk telkens - of hulle nou op hulle knieë is of nie - uit hulle sonde verlos: Kom tog, laat ons die saak met mekaar uitmaak... (1:18)!

\subsubsection{DIE ANTROPONOME SUBORDINASIE VAN GOD}

Wat gebeur in werklikheid in preke van hierdie aard? Die antwoord hierop mag, soos ek reeds gesê het, na 'n harde oordeel klink, maar dit word nie uit die lug gegryp of ligtelik geformuleer nie: God word verdring. Dit is, hartseer genoeg, heelwaarskynlik 'n universele homiletiese verskynsel, 'n kortsluiting wat van tyd tot tyd op feitlik alle kansels plaasvind, met verreikende gevolge. Rudolf Landau het byvoorbeeld na aanleiding van 'n uitgebreide ondersoek van Duitse preke oor die voorsienigheid tot die gevolgtrekking gekom dat daar 'n wydverspreide antroponome subordinasie van God plaasvind, 'n onderdrukking volgens menslike norme. Die dogmatiese topos van die concursus Dei of die cooperatio Dei et hominum (wyses waarop God en mens "saamwerk") word in die algemeen so verstaan, of in elk geval in taal so uitgedruk, dat die handelinge van God aan die algemene moraal van menslike handelinge gesubordineer word.

Dit is na my mening belangrik om daarop te let dat dit nie hier gaan om 'n teologiese dwaling wat op die periferie lê nie, maar om die moeder van alle dwalings, wat die hartklop van alle ware teologie radikaal antas. Ons het met ons paar aanhalings egter maar net geroer aan die ore van die seekoei. Die dieper misère van dié moeder van alle dwalings, dit wil sê die uiterste en logiese konsekwensie van die wettisisme, lê nog veel dieper. Daar kan sekerlik bespiegel word oor die uitwerking hiervan op die gemeentes wat onder die geklank daarvan moes kom. Die grondliggende is egter deurentyd die uitkansellering van die werklikheid van God. Luther het die negering van dié werklikheid niks minder as 'n annibilatio Dei, 'n uitwissing van God, genoem nie. Wettiese preke verkondig 'n onwerklike God, praat oor die verlossing van die wêreld asof God nie bestaan nie, asof God swygsaam en onwerksaam op die buitewyke van ons leefwerreld huiwer. Dit trek 'n streep deur die kruisdood en opstanding, deur die verheerliking van Christus en die uitstorting van sy Gees. Wettiese preke het 'n negatief eskallerende effek: nie alleen bring dit mee dat die Bybelteks verstom (vgl. hoofstuk 4), die gemeente in die waan van veredeling leef (hoofstuk 5), en die prediker vereensaam nie (hoofstuk 6), maar veral dat God op die kansel uitgewis word. Laasgenoemde is die mees radikale moment in die definisie van wettisisme wat in hierdie boek hanteer word. Hierop stuur alle vorme van wettisisme af; hierin lê die eintlike en uiteindelike oogmerk daarvan. 
Maar...kán God uitgewis word? Ja en nee. Nee: om oor die uitwissing van God te praat, is om hipoteties te praat. Dis juis die wonder van God dat Hy ten spyte van alles wat ons aan en met Hom doen, steeds God bly. En veral: dat die krag van die evangelie eintlik en uiteindelik nie deur mense gemuilband kan word nie! Die Woord van God kan nie met kettings vasgebind word nie! Die Woord kom nie leeg terug na die Afsender daarvan nie! Ja: die Woord van God kan stuit op die vlakgrond-onvrugbaarheid, die hardepad-mentaliteit, die doring-en-distel-ingesteldheid waarvan die gelykenis van die saaier praat (vgl. Lukas 8:4-15 ). 'n Mens kan jou ore daarvoor toedruk, of wel hoor... maar nie hoor nie. In hierdie skynbare dialektiek lê juis die misterie van die werking van God se Woord, 'n dialektiek wat ons op geen manier moet probeer "oplos" nie. God kom deur sy onweerstaanbare genade, en skep self die hoorders van sy Woord. En tog - hierdie hoorders kan soms stokdoof bly! In alles bly God egter God.

God moet in ons preke met doenwoorde beskrywe word. Hy is werkwoordelik, voortdurend God. Hy is God in beweging, wat telkens weer nuut en verrassend werk, telkens weer op weg met sy Ryk en sy wêreld is. Daarom moet die teologie van ons preke 'n “oop” teologie, 'n opwegteologie bly, waarin die ingrype van God mense telkens tot verwondering bring. Daarom mag ons preke God nooit manipuleer en subordineer en vasverf in 'n steriele, gearriveerde teologie, waarin die prediker presies weet hoe God "sal" handel nie.

\subsection{5 'N WETTIESE APOKALIPTIEK}

As ons egter nou 'n bietjie dieper aftas langs die ore van die seekoei, ontdek ons: nie alleen trek wettiese preke 'n streep deur die realiteit van God se teenwoordigheid nie, maar ook deur die realiteit van sy toekomstigheid. In wettiese preke ís God nie meer nie, maar kóm Hy ook nie meer nie. Mense - ongebroke, religieuse mense - kom nou in sy plek. Dikwels hoor ons: God "sal", maar dis nie 'n eskatologiese "sal" nie, nie 'n koms van God uit vrye genade nie, eerder 'n koms wat gedetermineer word deur die mate van toewyding en die intensiteit van optrede deur mense. Wettiese preke is prinsipieël oneskatologies. Hoop as 'n uitsig op die beloftes van God word vervang deur die verbete vroomheid van die godsdienstige mens. In die plek van die beloftes van God (promissio Dei) kom die potensiaal van mense (potentia populi). In 'n sin word die sirkel hier voltooi: nie alleen val 'n gesonde ktisiologie (skeppingsleer; vgl. verder hieroor hoofstuk 5) uit wettiese preke weg nie, maar ook die eskatologie. Vergeefs word daar in sulke preke gesoek na die Alfa en die Omega, na die Een wat is en wat was en wat kom, die Almagtige (Open. 1:8 ). 
In wettiese preke word nie meer saam met die skepping gesug om die bevryding van die verslawing aan die verganklikheid nie, om so tot die heerlikheid te kom wat hoort by die heerlikheid van die kinders van God nie (Rom. 8:21). In wettiese preke maak ons eerder self die wêreld reg. Of altans, leef ons onder die illusie dat ons kan.

Maar, wat gebeur as die eskatologiese horison in preke wegval? Die stereotipiese antwoord van moralisme hierop lui: voorsien 'n substituut! In die geval van die eskatologie is dit gewoonlik 'n verwronge tipe apokaliptiek. Dié apokaliptiek bied 'n raamwerk waarbinne mense met groot dringendheid en dikwels ook met openlike of bedekte dreigemente gedwing kan word om gehoor te gee aan die eise van die prediker. Dit gee aan die imperatiewe 'n sekere geladenheid, 'n onontkombaarheid, 'n plasing in 'n ruimte wat swanger is aan kosmiese en katastrofiese dinge. In ekstreme gevalle lei dit daartoe dat oordeelsprediking - wat sekerlik 'n bepaalde reg het - verword tot geperverteerde helleprediking. Dit alles word 'n magtige retoriese instrument in die prediker se hand om mense tot die gewenste handelinge of instellinge oor te haal. Die ironie is egter: veranderinge wat aangebring word uit angs en as gevolg van dreigement is nie duursaam nie. Lewenspatrone wat hieruit ontstaan, is normaalweg nie van diepgaande aard nie. Trouens, angs skep groter angs. Dreigemente maak verbete, maar troos nie - terwyl dít juis die bedoeling van die Bybelse apokaliptiek is, selfs wanneer dit 'n magtige stuk verkondiging van God se oordeel is.

Ek verwys na 'n preek oor 1 Joh. 2:18 e.v. Op die keper beskou, word alles in die preek, van die basiese struktuur tot die vernuftige retoriek, ingespan om 'n negatiewe klimaat voor te berei: benewens die apokaliptiese tekskeuse - wat sekerlik die prediker se goeie reg is - word 'n negatiewe mensbeeld algaande opgebou sodat die preek mense kan aanspreek omdat hulle nie op standaard is nie. Hulle is swakkelinge wie se lewe 'n misoes is, mense wat huiwer. Veral die koppeling tussen die apokaliptiese teks en die tye waarin mense in die "nuwe" Suid-Afrika leef, bied aan die prediker 'n forse hulpmiddel om sy hoorders op te roep. Die Bybelteks handel oor die "laaste uur" waarin die antichris optree; die preek dra die stemming oor van mense wat in die nuwe Suid-Afrika in hierdie laaste uur lewe, waarin antichristelike magte, ja die duiwel self in 'n worstelende land vol allerlei bedreiginge aktief werksaam is. Wie kan nou nee sê as dít die agtergrond is waarteen oproepe gemaak word? Die punt is net dat die gemeente in dit alles wél met 'n reeks opdragte, máár troosteloos gelaat word. Wel begin die preek met die beklemtoning van die objektiewe heil, extra nos, maar onder die invloed van die stygende imperatiewe lyn verflou dit tot so 'n mate dat die preek slegs met 'n skrale verklaring kan eindig dat God (moontlik) aan ons sekere dinge "kan gee" - indien ons natuurlik na 
wense optree. Dit word afgerond met 'n uitputtende sin wat die gemeente dalk vasberade, maar troosteloos huis toe stuur:

"Dit is hoe Hy (God) dit wil hê en dit is wat ons moet wees. Amen."

Tot sover die eerste rondte van ons preekanalitiese toer deur die mynveld van die teologiese disintegrasie van stemme (vgl. 2.5.2). Sinne - en analises - soos hierdie roep as't ware die volgende kernvraag op, 'n vraag waaraan geen prediker van die Woord kán ontsnap nie: maar, hoe preek ek dan die evangelie? Hieraan skenk ons onder meer in die volgende hoofstuk aandag. 


\section{Preekvoorbeeld 1}

\section{NET JESUS ALLEEN \\ (Markus 9:2-8)}

In die San Marco museum in Florence is daar 'n merkwaardige skildery te sien van die vyftiende eeuse kunstenaar Fra Angelico. Dis 'n uitbeelding van die verheerliking van Christus op die berg, en die Christusfiguur, wat die fokuspunt vorm, vul feitlik die hele skildery. Hy staan met uitgestrekte arms daar, omring deur 'n hemelse wit lig. Op die rand van die skildery letterlik as randfigure - sien 'n mens die verskrikte dissipels, Petrus, Jakobus en Johannes. Van die kante kyk onder andere ook Moses en Elia na binne, in aanbidding voor die verheerlikte Christus.

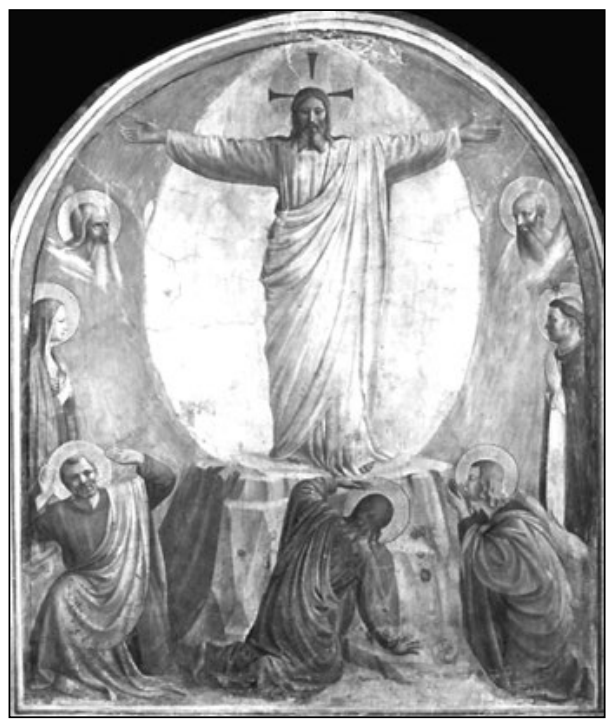

Hoe meer 'n mens na die skildery kyk, hoe meer ontdekkings doen jy daarin - soos dit maar die geval is met goeie kuns. Op die voorgrond, as 't ware as die eerste dimensie of prentjie, is uiteraard die verheerlikte Christus, die Here van die geskiedenis en die wêreld, die Koning van die kerk. As jy 'n bietjie dieper kyk, sien jy egter die tweede dimensie: die arms van Christus is naamlik presies só uitgestrek as wat dit aan die kruis was, met sy handpalms na vore gedraai soos wat dit aan die kruis vasgekap was. Die skildery wil sê: die Een wat verheerlik is, is niemand anders nie as die Een wat gekruisig sou word; die Een wat gekruisig sou word, is die Een wat verheerlik is. 
Wie is Jesus vir jou? Watter prentjie kom by jou op wanneer jy die naam Christus hoor? Kom ons wees eerlik: verkies ons nie prentjie nommer een bo prentjie nommer twee nie? Die verheerlikte Christus bo die Gekruisigde nie?

Petrus verwoord in elk geval hierdie keuse nie alleen namens die drie dissipels op die berg nie, maar namens baie, wanneer hy verskrik stotter: "Rabbi, dit is goed dat ons hier is. Laat ons drie hutte bou: een vir $U$, een vir Moses en een vir Elia." (5) Petrus het - ten spyte van sy oorstelping - diep binne-in hom geweet: om saam met die verheerlikte Christus te wees, is die hoogtepunt van 'n mens se bestaan. Hieroor het álles eintlik gegaan. Hier het die hemel aan die aarde geraak, het hemel en aarde ineengeskuif. Hier, in die ligkring van dié Christus, het ons gearriveer. Hier wil ons bly so lank as wat ons kan, nee, vir altyd. Ag, mag hierdie Jesus ons tog nooit weer verlaat nie. Kan ons Hom nie 'n permanente tuiste aanbied nie, 'n hut, 'n ewige woonplek by ons...?

'n Mens kan Petrus sekerlik ook nie kwalik neem nie. Trouens, alles in die verhaal is afgestem daarop om op die wonder van hierdie heerlikheid te wys. Die verhaal is vol ryke simboliek. Die "ses dae" waarna aan die begin verwys word (2), is waarskynlik 'n literêre tegniek om aan te dui dat die oomblik swanger aan openbaring is, dat dit inderdaad 'n gelade oomblik is. Die hoë berg is natuurlik' $n$ tipiese Bybelse aanduiding van 'n ontmoetingsplek tussen God en mens, 'n plek waar jy as 't ware die naaste aan die hemel is. Die voorkoms van Jesus met sy blink klere, spierwit soos niemand op aarde dit kan maak nie (3), herinner aan 'n boaardse, Goddelike heerlikheid - wat nou hier op aarde verskyn. Moses en Elia is by uitstek verteenwoordigers van God se openbaringe aan sy volk in die Ou Testament, en die stem wat uit die wolk praat laat jou terugdink aan talle openbaringe van God aan hierdie volk, byvoorbeeld op die berg Sinai. Kortom, wat hier gebeur, is wonderlik, Goddelik, heerlik. Dit verklaar dat die Een wat in die middelpunt staan inderdaad die geliefde Seun van die Vader is soos die stem uit die wolk sê - 'n bevestiging wat 'n mens dwarsdeur die Markusevangelie aantref.

Dié gebeure op die hoë berg is as 't ware 'n vooruitgrype op die toekoms, 'n gordyn wat oopgetrek word, 'n sluier wat gelig word, nie alleen op die opstanding van Jesus uit die graf nie - want daar is duidelike ooreenkomste tussen die verheerliking op die berg en die opstanding van Jesus - maar veral op ons ewige toekoms: die aanbidding van die verheerlikte Jesus. Ag, en wie van ons wil nie nou al dit beleef nie, wie van ons hunker nie saam met Paulus om heen te gaan en met Christus te wees nie, want is dit nie verreweg die beste vir ons nie (Fil. 1:23)? Waarom moet ons nog so lank daarvoor wag? Waarom kán ons nie nou maar by ons ewige bestemming arriveer nie? Waarom kan ons nie nou maar oorstap uit hierdie wêreld van die dooies na die wêreld van die lewendes, en die Lewende nie?

Nee, ons kan nog nie, sê ons teksverse. Ons het nog nie by daardie bede- 
ling gekom nie. Oorstaptyd het nog nie aangebreek nie. Ons is nog in hierdie bedeling, moet nog berg-af, terug na die valleie, die dieptes, die alledaagse lewe, die opneem van jou kruis en die navolging van Christus, die Gekruisigde. Ons kan nie hutte vir die Here bou nie, kan Hom - in elk geval nie op só 'n wyse - by ons vashou nie. Ons het self nie eers hutte waarin ons vir altyd op aarde kan vertoef nie, is eerder vreemdelinge en bywoners (1 Petrus 2:11). Daarom staan daar ook, veelseggend, in Markus 9:8: En meteens, toe bulle weer kyk, sien bulle niemand meer nie, net fesus alleen by bulle. Net Jesus alleen, nie meer 'n hemelse glans wat hom omring, of 'n stem wat uit die wolk praat nie. Net Jesus alleen, soos die dissipels Hom leer ken het. Net Jesus alleen, en sy woorde wat gehoorsaam moet word (7b).

Ja, natuurlik gee die Here van tyd tot tyd sekere "bergtop-ervarings" aan ons, momente vol heerlikheid, wanneer jy nie eers veel op jou tone hoef te staan nie, of jy kan aan die hemel raak. Oomblikke waarin jou voete as 't ware so 'n bietjie van die grond af lig, en jy die toekoms, die einddoel van alles, helderder as ooit tevore sien. Dit kan in 'n erediens wees, of met die lees van 'n Bybelvers, of 'n sagte aanraking van genade wat jy nie eers mooi onder woorde kan bring nie. Wanneer jy net weet: ek het tuisgekom, en dié wete jou asem wegslaan.

Maar dan... gaan ook dit verby. Dan besef jy opnuut: hierdie ervaringe is bonusse, maar dis nie voortdurend nie. Dan is dit net weer jy en Jesus alleen. 'n Jesus wie se woorde jy moet gehoorsaam. Dan skuif die tweede prentjie, die een van die Gekruisigde, weer na vore, en hoor jy sy stem: As iemand agter My aan wil kom, moet by homself verloën, sy kruis dra en my volg (Markus 8:34).

Hierdie verhaal is in Markus geplaas om ons te herinner dat ons in hierdie bedeling nie uit 'n teologie van heerlikheid kan leef nie, maar uit 'n teologie van die kruis, dat die eerste prentjie wat by ons opkom as ons die Naam Christus hoor, dié van die Man aan die kruis moet wees, soos Luther tereg gesê het. Ons moet weer berg-af gaan, uit die dampkring van die verheerliking, om die Here in gehoorsaamheid en navolging te dien. Ons leef immers nie in aanskoue nie, maar in hoop (vgl. Rom. 8:24,25). 'n Mens dink aan wat Kierkegaard gesê het:

"Daar was 'n tyd - dit het so natuurlik gekom, dit was kinderlik - toe ek geglo het dat God se liefde ook daarin tot uitdrukking gekom het deurdat Hy aardse 'goeie gawes', geluk, voorspoed gestuur het. Hoe voorbarig was my siel in begeerte en waagmoed... Ek het vir alles gebid, selfs die mees voorbarige dinge... En wanneer alles geslaagd was, hoe ryk was my siel in dankbaarheid, so gelukkig om dankie te sê - want ek was oortuig dat God se liefde tot uitdrukking gekom het in die goeie gawes van die aarde wat $\mathrm{Hy}$ na my toe gestuur het.

"Nou is dit anders. Hoe het dit gebeur? Heel eenvoudig, maar 
bietjie vir bietjie. Bietjie vir bietjie het ek agtergekom dat almal vir wie God regtig liefhet, die voorbeelde van gelowiges deur die eeue, almal in hierdie lewe moes ly. Ek het ook ontdek dat dit die boodskap van die Christendom is: om deur God liefgehê te word, is om te ly."

Ten diepste is dít die boodskap van die verheerliking op die berg: dit is wie Christus is - die ewige Seun van God - maar Hy is nou nog nie op dié wyse by ons teenwoordig nie. Sy koninkryk is nou nog grotendeels verborge. Hy kom na ons toe nie in 'n skitterende gestalte nie, maar in die gedaantes van die hongeriges, die dorstiges, die vreemdelinge, die naaktes, die siekes, die gevangenes (vgl. Matt. 25:31-46). Hy is een van die geringstes in ons midde. Jy kan Hom maklik miskyk, jou maklik met Hom misgis. O ja, $\mathrm{Hy}$ is die verbeerlikte, maar selfs as Verbeerlikte is Hy by ons teenwoordig as die Gekruisigde. Dis die manier waarop sy koninkryk tans in ons midde kom en sigbaar word - vir diegene wat dit wil sien. God se koninkryk kom in verborgenheid. Maar dis hier! Dis in ons midde!

Helmut Thielicke skryf aangrypend hieroor in sy boek oor die Onse Vader: Die gebed wat die wêreld omspan. Die boek is geskryf tydens die Tweede Wêreldoorlog, toe die kerke waarin hulle bymekaargekom het, die een na die ander gebombardeer is. Juis in hierdie tyd, sê hy, het hulle die koms van God se koninkryk helderder kon sien as in tye toe alles nog met hulle goed gegaan het, want nou was hulle weer van God afhanklik. Hulle het opnuut besef: God se koninkryk kom juis tussen die ruïnes deur, ook die ruïnes van ons lewensmislukkings. Hy skryf onder meer soos volg:

"Die grootste geheimenisse van God speel hulle altyd in die diepte af... God bou sy koninkryk in die verborgenheid. Dis soos by die oprigting van 'n brug wat onder baie steiers en beskotte gebou word sodat'n mens die bouwerk self nie sien nie. 'n Mens hoor net die duisende hamerslae. Op'n dag word die steiers en beskotte weggeneem en die bouwerk staan voor ons verwonderde en beskaamde oë. God was nie ledig terwyl ons tevergeefs na tekens van sy spore en sy werk gesoek het nie."

So is dit: ons leef nou nog in die bedeling van die bouproses, van diensbaarwees, van hoop sonder aanskoue. Maar ons is nie alleen nie. Op die skildery van Fra Angelico kom, as jy lank genoeg daarna kyk, ook nog 'n derde prentjie uit die verf: die een van die verheerlikte, gekruisigde Christus wat sy arms na jóú toe uitsteek, om jóú en om sy kerk slaan, en sê: $E k$ is by julle al die dae tot die voleinding van die wêreld (Matt. 28:20). Die skildery bevestig: ons is nie meer (of nog nie!) op die berg nie. Ons is in die vallei, in die dieptes. Maar, ons het Jesus by ons. Net Jesus alleen.

En dis genoeg. 


\section{Die lewende stem van die evangelie: wanneer die Bybelteks praat}

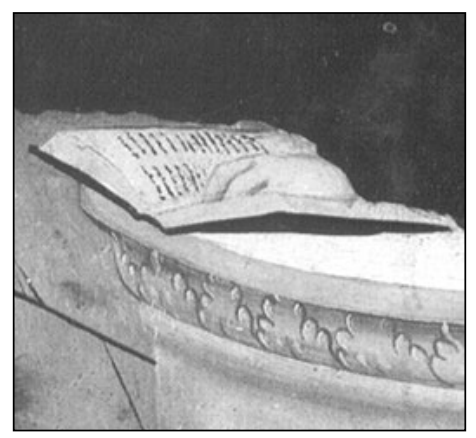

In hierdie hoofstuk dink ons na oor die rol van die Bybelteks in die prediking, in die lig van

- Die aard van die Skrif self, as multidimensionele, menslike en Goddelike dokument met 'n unieke boodskap

- Die verantwoordelikheid van predikers om daarom op die regte manier na die Skrif te luister, en

- Preekvoorbeelde van 'n mislukte (moralistiese) luister na die Skrif

\subsection{Die multidimensionaliteit van die Skrif}

God ís teenwoordig. Maar die Woord, die evangelie daarin, moet dit vir ons sê voordat ons dit kan sien. Hierdie $s \hat{e}$ is inderdaad 'n daadkragtige gebeurtenis wat tegelykertyd ons oë vir die Teenwoordige oopmaak, 
oftewel, vir ons 'n bril opsit waardeur ons die teenwoordigheid van die handelende en verlossende God kan waarneem (Calvyn). Dit is dus van deurslaggewende belang dat ons die aard en funksie, maar veral die wonder en "volheid", die multidimensionaliteit, van hierdie bril sal verstaan...

In die Bybel hoor ons die verhale van mense wat God gesien, en dit oorvertel het - presies dít wat ons in die prediking wil doen! Die Skrif dui die "styl" aan wat pas by die waarneem van God. Dit bevat nie bloot kliniese opmerkings of naakte feite (bruta facta) oor God nie, maar bied eerder voorbeelde van hoe gepraat word wanneer God gesien word - soos Johannes die Doper, wanneer hy uitroep en uitwys: dáár is die Lam van God wat die sonde van die wêreld wegneem! (Joh. 1:29)

Op 'n verskeidenheid van maniere roep die Bybel uit: aha! Die Bybel roep dit só uit dat dit jou aan die wonder sit, jou intrek... totdat jy tot 'n nuwe ontdekking van jouself, van ander, en van God kom, kortom, totdat jy anders as voorheen sien. Dis by uitstek dié skool waar jy, benewens spraakoefeninge, ook oogoefeninge kan doen, en oogtoetse kan ondergaan. Die Bybel open op 'n verhalende wyse nuwe horisonne, nuwe perspektiewe waarvan jy nóóit sou kon droom nie! Dit bied alternatiewe, wat juis meebring dat jy die wêreld waarin jy tans woon núút sien, nuut bewoon, en so nuut máák.

Kan 'n mens dié volheid van die Skrif met 'n enkele preek of 'n metode van preek uitput? Natuurlik nie! Ons moet preke nie verstaan as 'n klaarproduk wat gelewer word soos 'n artikel op die mark nie; eerder as 'n proses, 'n ontwikkeling wat baie aanhakpunte het, wat insluit, wat oop arms het. 'n Preek is nie 'n eindproduk, nie 'n finaal afgeronde rede, eenhonderd persent reg nie! Eintlik kan ons preke nie (klaar) "maak" nie, hoogstens van tyd tot tyd uitroepe gee van die ontmoeting wat ons met God in die Bybelteks gesmaak het. Preke mag maar, en moet selfs, "gate" in hê, "linguistic gaps" (Umberto Ecco), ruimtes waarbinne óns nie alles weet nie, maar waarin ons die fluisteringe van die teenwoordige God kan hoor...

Ons moet inderdaad só preek dat ons die opsies oophou, in dié sin dat ons 'n basiese wantroue openbaar teenoor uitsluitlike uitlegmetodes of preekvorme wat as "resepte" 'n "objektiewe" en foutvrye preekresultaat moet waarborg.

In dié sin is die bedoeling van die preek dus nie alleen om onaantasbare sekerhede oor te dra nie, maar veral om nuwe perspektiewe op dié sekerhede te open, 'n nuwe verbeeldingskrag "to picture, portray, receive, and practice the world in ways other than it appears to be at first glance when seen through a dominant, habitual, unexamined lens" (Brueggemann 1993:13). Hiervoor bly die omgang met die Bybelse teks onontbeerlik: dit 
bied die bron wat nie deur ons stereotipes verskraal of versmoor of uitgedoof of verdonker mag word nie. Inteendeel, wie "hard aan die teks" bly, sal ontdek: Ek word bevry van my stereotipes, my verveling en daarom my gebrek aan verootmoediging en verwondering...

Die ou gebruike waarop kerklike, "absolute" waarhede in die verlede verwoord is, word (gelukkig) tans opnuut bevraagteken - veral ook omdat hierdie waarhede of kennis dikwels tot magsmisbruik gelei het (soos uitgedruk in die leuse: kennis is mag?).

Die patriargale, hiërargiese, outoritêre en monologiese styl wat baie van ons prediking en teologie gekenmerk het (vgl. weer hoofstuk 1), moet nou plek maak vir' $n$ groter sensitiwiteit vir die verskeidenheid behoeftes in die gemeente, maar ook die meervlakkige aard van die Bybelse teks self - wat die moontlikheid van meer as een, "regte" antwoord of boodskap insluit, asook die wenslikheid van 'n herverdeling van die uitleggersvoorregte van die verlede.

In die verlede kon ons byvoorbeeld té maklik voorgee dat ons dié waarheid deur middel van ons eksegetiese metodes as die absolute kern van sekerheid as 't ware klinkklaar kan laat uitkristalliseer. Die groot nadeel van hierdie uitgangspunt was naamlik die feit dat dit (onbewus?) meegewerk het tot 'n soort stolling van ons Godsbeeld, tot 'n patroonagtige invoeging van God in óns skematjie, tot Sy skadeloosstelling en verburgerliking ooreenkomstig óns stereotipes.

Hierdie verskynsel van stereotipering was veral pynlik in die era van die sogenaamde "volksprediking" in die Nederduitse Gereformeerde Kerk in Suid-Afrika, toe die wese en die handelinge van God presies en absoluut in 'n soort "analogieskematisme" vasgelê is. In dié analogieskematisme onstaan 'n vaste beeld, van die mens én God. Eenmalige situasies en gebeure van die verlede word net so oorgedra op huidige situasies en gebeure, en die dinamiese en verrassende handelinge van die onvergelyklik werksame God (HW Wolff) gevolglik ingekort. Hy móét dan presies só handel soos in die verlede - veral ook nog omdat ons Hom met allerhande moralistiese optredes daartoe "oortuig". Male sonder tal het 'n mens predikers uit daardie tydperk hoor sê: "Dit is vandag nog net so..." of: "God handel vandag presies net soos in die tyd van Israel", met die bedoeling om die identiteit van die Afrikanervolk te versterk as mense wat presies ervaar wat Israel destyds ervaar het, en dus ook verseker kan weet: God is (ook) vir óns (vgl. Cilliers:1994).

Maar... God pas tog nié in 'n patroon in nie! Ook nie een van absolute sekerheid en onaantasbare vastigheid nie! Die Bybelse teks, wat oor die Gans-Anderse God getuig, kan daarom sonder skroom op 'n kontrasterende, selfs "onlogiese" wyse oor God praat. Trouens, in die Joodse denke (veral die sogenaamde "midrash-skool") word doelbewus weggestaan 
van die soeke na een "betekenis" van die teks, en eerder'n veelheid van interpretasies en dus "waarhede" toegelaat. Brueggemann wys byvoorbeeld daarop dat Freud se droomterapie moontlik hierdeur beïnvloed is, 'n terapie waarin 'n rykdom van interpretasies van een droom moontlik en selfs wenslik is (1995:316). Om Bybelse tekste te lees en te droom, het blykbaar veel gemeen!

Die Bybelse teks verruim egter nie ons (stereotiepe) perspektief op 'n gedwonge wyse nie, maar bevraagteken eerder die status quo op 'n subversiewe wyse, deur spelend, uitlokkend ander moontlikhede voor te hou. Dit deurbreek die geyktheid van vaste formules, die verveling van dooie gewoontes, die blote herhaling van afgehandelde en onbetwiste waarhede wat geen bedreiging of uitdaging meer vir die hoorders daarvan inhou nie. Die Bybelteks verset hom teen 'n afskaling van sy eie, inherente rykdom, teen 'n aanpassing en inpassing daarvan by die burgerlike moraal van religieuse mense, teen 'n reduksie tot iets wat vroom mense kan hanteer. Om te preek, is om te luister na die veelklankigheid van die teks, is om te dans na die wysie van die teks. Ons wil te dikwels net op ons eie (een) kitaar en snaar speel!

\subsection{1 ... OPEN POORTE TOT NUWE WÊRELDE...}

Watter implikasies het bogenoemde alles vir die prediking? As 'n eerste, algemene reël kan gesê word: wie iets van die aard van die Skrif ontdek het, iets van die multidimensionaliteit daarvan begin insien, kan nie anders nie as om verbeeldingryk(er) te begin preek (vgl. Cilliers 1994:585 e.v.; ook verder hoofstuk 6). Die Bybelse teks bied naamlik 'n vreemde, maar verlossende woord, 'n woord met 'n "weerbarstigheid" (Brueggemann: "abrasiveness") wat die eendimensionaliteit van ons wêreld deurbreek om te verras, te provokeer, ontbloot, onthul - met die oog op 'n intog in 'n nuwe wêreld: die aanvaarding en lééf van 'n evangeliese alternatief.

Om te preek, is om die Bybelse teks só voor die gemeente op te hou, en die Een van wie die Bybelse teks getuig só aan die gemeente uit te wys, dat die gemeente deur hierdie teks heen die nuwe wêreld(e) van hierdie God kan "sien". Dis om te kom tot 'n nuwe verbeelding, 'n her-verbeelding van dit wat volgens die teks ís, en daarom ook in ons wêreld kán wees, is om deur die vergrootglas (bril) van die teks dinge raak te sien wat jy vantevore misgekyk of as onbelangrik beskou het.

Prediking is om te sê: die koninkryk van God is soos...!

Hierdie "soos" is 'n verbeeldingryke, skeppende soos: dit breek die verstokte vergelykings waarmee ons leef af, verset hom teen die "soos" van al die ideologieë en al die -ismes waardeur ons so geknel was en steeds is, om op ander moontlikhede te wys, en skep só tegelykertyd dié moontlikhede 
vir diegene wat die "soos" van die Woord hoor. Om in die prediking te sê "soos" is om 'n poort te ontsluit, 'n deur oop te maak op die panorama van God, is om die sluiers van die gesig weg te neem sodat mense opnuut kan sê: $a b a !$

Dít geskied nie noodwendig deur groot, eenmalige en universele waarhede aan die gemeente voor te hou nie, maar dosisgewys, deur in elke preek 'n spesifieke teks binne die spesifieke konteks van die plaaslike gemeente "oop" te breek, 'n klein teks wat 'n klein blik bied op die groot panorama van God, 'n klein "soos” wat paradigmaties is van die groot "soos" van die koninkryk.

Elke preek is soos (!) 'n klein "venstertjie" in die veel-venster-oog van die heuningby, wat elkeen 'n afgeronde visie bied, en tog nie volkome is sonder die ander vensters nie, alleen sinvol is binne die groter geheel van die prentjie. Of: prediking is om saam met die gemeente deur die "viewmaster" van die teks te kyk - elke Sondag verskyn 'n nuwe, verrassende prentjie voor ons oё, 'n prentjie wat ons blinkoog soos kinders kan laat, vol vreugde en verwondering, en soms ook vol hartseer en verootmoediging ...

Prediking wat één venster of prentjie, één "soos" tot dié waarheid verhef, raak geïsoleer van die panorama van God, eenogig, verbeeldingloos. Verbeeldingryke prediking bied daarenteen 'n rykdom van perspektiewe, en staan as sodanig teenoor ons gebruiklike wyses van didaktiese, dogmatiese of moralistiese prediking (tussen hakies: daar is niks so verbeeldingloos soos moralistiese prediking nie - al wat dit die mens bied is hom- en haarself! Hoe vervelig!). Verbeeldingryke prediking is soos terapie: dit begelei die hoorder vanuit die ou, eendimensionele wêreld na die vele, asemrowende landskappe van die koninkryk van God.

Dit kan egter nie genoeg beklemtoon word nie: daar is géén manier waarop ons verbeeldingryk gaan preek buite 'n grondige en getroue omgang met en "werk" aan die Bybelteks om nie. Die (teologies-wetenskaplike; gebeds- en geloofs-) arbeid aan die teks is die skoonvee van die bril, waarsonder die uitsig vertroebel sou wees. Daarmee verkry ék egter nie soseer "'n greep op die teks" nie, maar bevestig die God van die teks sy greep op my; word die teks nie soseer 'n "wetenskapsobjek" wat ek klinies kan dissekteer en analiseer nie, maar word ek ingelei in 'n wêreld waarin ook my eie lewe op die spel is. Om met die Bybelteks besig te wees, is nie net om na die bril van die Skrif te kyk nie, maar ook deur die bril, om uiteindelik die wêreld vóór die bril (Bybelteks) te kan sien (Ricoeur). Preke moet nie net "mooi" wees, in die sin dat dit "korrek" is nie; dit moet God aan ons uitwys, op verrassende manier, ver bo wat ons sou kon bid of dink...

Ek sê weer: alleen hy of sy wat hard aan die Bybelteks klou, wat knaend daarmee besig is, verkry die vryheid om so verbeeldingryk daarmee om te 
gaan. Die een kan nie sonder die ander nie; die een ontspring uit die ander. 'n Mens dink aan Paderewski se opmerking oor genialiteit: "Before I was a genius, I was a slug" - die prediker moet hard aan die teks bly, voor hy of sy die drama daarvan kan opvoer!

'n Mens dink aan Karl Barth wat sy laaste woorde aan sy studente moes rig. Hy is deur Hitler uit Duitsland verban omdat hy nie die eed van trou teenoor die Führer wou uitspreek nie, aangesien hy van mening was dat dit sy eed van trou teenoor Christus sou skaad. Hy moes die land binne vier en twintig uur verlaat, en het net 'n paar minute gehad om van sy studente afskeid te neem. Sy laaste woorde aan hulle was: "Die belangrikste ding wat julle moet doen, is eerstens: eksegese, tweedens: eksegese, en derdens: nogeens eksegese."

Dit bring ons by

\subsection{Die menslikheid van die Skrif}

Die Bybel is 'n volledige menslike woord, dit wil sê, 'n boek soos enige ander boek, literatuur soos enige ander literatuur. Die Bybel het nie direk uit die hemel geval, en is nie deur engele geskryf nie. Inteendeel, dis deur ménse geskryf, deur 'n aantal histories aanwysbare figure (en indien nie histories aanwysbaar, steeds deur ménse), wat met hulle eie individualiteit en grammatikale vaardighede (of gebrek daaraan), hulle kenmerkende skryfstyle, woordkeuses en persepsies, die ses en sestig boeke van die Bybel vir ons nagelaat het. In hierdie ses en sestig boeke tref ons dan ook'n ryke verskeidenheid van genres, literêre strategieë en verhaalontplooiings aan. Die Bybel bruis letterlik van égte menslikheid en van égte skrywerskreatiwiteit.

Dit bring onder andere mee dat daar ook, vanweë die menslikheid van die persepsies en vertolkingsprosesse, 'n hele aantal skynbare feitelike teenstrydighede in die Bybel voorkom (dink maar net aan die soms uiteenlopende maniere waarop die sinoptiese evangelies oor die lewe, sterwe en opstanding van Jesus berig). Met die eerste lees wil dit voorkom asof sekere verhale gewoon net nie klop met ander verhale oor dieselfde gebeure nie. Beteken dit nou dat die historiese gebeurtenis as gebeurtenis onder verdenking geplaas word? Dat die feitelike realiteit as onderbou van byvoorbeeld die Jesusverhaal in die gedrang kom? Nee, maar wel dat die vertolkingsprosesse van hierdie gebeure en feite tog nie anders plaasgevind het as deur ménse nie.

Dit impliseer verder dat die Bybel - indien ons dit op 'n verantwoordelike wyse wil lees - met behulp van historiese en liguistiese wetenskappe bestudeer behóórt te word, wetenskappe waarin onder meer gevra word na die sosiale agtergronde van die Bybel (die sogenaamde wêreld agter die 
teks), die literêre aard van die teks self (die wêreld in die teks), asook die werkings - en vertolkingsgeskiedenis van die teks (die wêreld voor die teks; vir 'n opsommende bespreking, vgl. Smit 1987:26 e.v.).

Daar sit nie magiese krag in die Bybel se woorde as sodanig nie. Die letters van die Bybel gloei nie in die donker nie. Dis gewoon letters op papier, gedruk met ink, volgens voorgeskrewe (menslike) drukprosesse. Op 'n meer dogmatiese manier gesê: die openbaring van God is groter as die Bybel, gaan ook die Bybel vooraf. Die Bybel is slegs die boekstawing van God se openbaring, en hierdie boekstawing is deur ménse gedoen. Kortom: die Bybel is nie God of sy openbaring self nie, en mag dus ook nie naas, of in die plek van God skuif om 'n voorwerp van aanbidding te word nie (die sg. Bibliolaterie; vir 'n uitgebreide bespreking van sommige van die maniere waarop die Skrif al beoordeel en vertolk is, vgl. Vaessen 1997:36 e.v.).

Daar sit egter iets geweldig bevrydend, ja troosryk, in die menslike aard van die Skrif. Dit onderstreep naamlik die feit dat God in mensetaal praat. Dat God nie sy wil vir ons deur'n groot megafoon uit die hemel oor die aarde heen laat weergalm het nie, maar dat Hy - letterlik by wyse van spreke - in die gebrokenheid ook van ons mensetaal kom inklim het. Dis 'n wonder: God praat Grieks en Hebreeus, en uiteindelik ook Afrikaans! God se stem word verwoord en verklank in woorde en klanke wat ook ék kan verstaan! Trouens, ons sou kon sê dat die Skrifgeworde Woord (die Bybel) net so 'n groot wonder is as die Mensgeworde Woord (Jesus). Die motief van die inkarnasie (menswording) sit ook agter die boek wat ons die Bybel noem. Wie iets hiérvan verstaan, kom opnuut in verwondering oor die neerbuigende aard van God se openbaring.

Calvyn skryf dikwels oor die aanpassing van God by mense. Dit het alles te make met die pedagogiese motief in die heilsekonomie: ons sou God nie geken het as Hy Hom nie na ons toe neergebuig het en met ons op só 'n menslike wyse gepraat het dat ons Hom kon verstaan en kon weet dat Hy naby ons is nie. Sy Woord val nie op 'n geheimnisvolle wyse uit die wolke nie, maar kom tot ons in verstaanbare begrippe, grammatika en woorde (vgl. Berkouwer 1975:176). As gevolg van die swakheid van ons kapasiteit, praat God binne die grense van ons vermoëns: "Because our weakness cannot reach his height, any description which we receive of Him must be lowered to our capacity in order to be intelligible. And the mode of lowering is to represent Him not as He really is, but as we conceive of Him." (Calvyn Inst. 1/17/13; ook $1 / 11 / 3 ; 2 / 11 / 13 ; 2 / 16 / 2$ )

Dit is 'n geweldige gedagte. Want, dit impliseer ook dat 'n mens, soos wat jy na Jesus kan kyk, en alles behalwe God raaksien - eerder 'n tipiese Joodse man - jy ook die Bybel kan lees, en niks ander as ('n ryke verskeidenheid van) literatuur kan opmerk nie. Om die parallel 'n bietjie verder 
te trek: daar was nie 'n stralekrans rondom die kop van die Kind Jesus nie, ondanks ons kerskaartjies. Daar was nie 'n hemelse wasigheid in die stal wat die strooi in goue drade en die stof in blinkertjies omskep het nie. In die krip lê 'n Kind met krom beentjies wat skop, met naeltjies aan sy vingers en tone, met geklemde vuisies wat in toe ogies vroetel. Wat uit die stal uit opklink, is nie harpmusiek nie, maar die steungeluide van 'n baba (vgl. Cilliers 1991:37-38). Luther skryf treffend:

"Zesus was nie 'n spook nie, maar het onder mense gewoon; Hy het oё, ore, 'n mond, neus, bors, lyf, bande en voete gehad net soos ek en jy, melk by sy ma gedrink, saam met ons geëet en gedrink, was toornig, het gebid, getreur, geween."

Die Bybel moet nie - ook in die prediking - in 'n blinkerige kerskaartjie omskep word nie. Nie in 'n boek met vergulde, maar onmenslike en onwerklike woorde nie. Daarvoor is God se inkarnerende toenadering tot ons, ja, sy aanpassing by ons, te groot. Maar, dis inderdaad God wat Hom by ons aanpas...

\subsection{Die Goddelikheid van die Skrif}

Die Bybel is ' $n$ volledige goddelike Woord, dit wil sê anders as enige ander boek, anders as enige ander literatuur. Dit mag na 'n volslae teenstrydigheid klink, maar moet eerder 'n wonder genoem word. Binne die ruimtes van menslike taal word God se Woord gehoor! Om terug te keer na die motief van die inkarnasie: Van Christus het die kerkvaders gesê: vere deus et homo (waarlik God én mens), en van die Skrif mag ons ook bely: waarlik goddelik én menslik.

Ons mag daarom nie sê dat net sekere gedeeltes van die Bybel wel God se Woord is, maar ander dele waarskynlik nie. Eerder dat alles in die Bybel tegelykertyd menslike én goddelike woorde is. Die Bybel is nie deur engele geskryf nie, maar deur mense, maar dit was mense wat op 'n besondere wyse deur die Heilige Gees geïnspireer is (vgl. bv. 2 Pet. 1:20, 21).

Daarom kan en moet ons - na my mening - met net soveel oortuiging vashou aan die vier klassieke kenmerke wat deur die kerkvaders ten opsigte van die Skrif geformuleer is, naamlik dat dit gesag het, dat dit noodsaaklik, duidelik, en genoegsaam is, dit wil sê dat die kanon geslote is, en ons nie in buite-Bybelse bronne moet soek na hierdie unieke stem van God nie (Berkouwer bespreek hierdie kenmerke van die Skrif breedvoerig; 1975:240 e.v.).

Die Bybel hoef nie verdedig te word nie. Dit spreek vanself. Al sou jy in 
die lig van die menslike aard van die Bybel heelwat kon sê oor die skynbare feitelike teenstrydighede in die teks, sou jy in die lig van die goddelike aard daarvan veel meer kon sê. Jy sou byvoorbeeld nie uitgepraat kon raak oor die werkingsgeskiedenis van die Bybel nie. Duisende, nee, miljoene mense, kan immers getuig dat die boodskap van die Bybel hulle lewens wesenlik verander het. Immers, dis die doel van die Woord van God - dit kom om ons te verander. Groot kerkfigure soos Augustinus, Luther en Barth het'n pertinente ervaring met God vanuit spesifieke Skrifgedeeltes gehad - en die wolk van getuies kan in dié verband sonder twyfel veel uitgebrei word. Inderdaad: die Bybel is 'n instrument in die hand van God, deel van dié proses waardeur Hy deur sy Woord en Gees sy kerk van die begin van die wêreld af tot die einde toe vergader, beskerm en onderhou (HK 21/54).

Daarom word die boodskap van die Bybel ook nie net deur literêr wetenskaplike metodes ontsluit nie - hoe belangrik dit ookal mag wees - maar ten diepste deur die innerlike getuienis van die Heilige Gees self (testimonium spiritus sancti internum). Dis egter belangrik om nie uit die oog te verloor dat die een nie teenoor die ander staan nie. Wie die menslike en goddelike karakter van die Skrif teenoor mekaar stel, loop gevaar om eensydig te word, en juis nie die unieke stem van die Skrif te hoor nie.

Dit bly die heerlike, onbegryplike paradoks: die woorde van die Bybel is deur mense geskryf, en tog gebeur die wonder dat dit tot jou kom as niks anders nie as die Woord van God. Die woorde van die Bybel gloei nie in die donker nie, en tog kan dit 'n (Goddelike) gloed in jou donkerste uur oor jou laat val!

Inderdaad: God se Woord inkarneer in menslike woorde - om ons te transformeer.

\subsection{Die unieke boodskap van die Skrif}

Die Bybel het 'n unieke boodskap. Wie iets anders as hierdie boodskap in die Bybel wil hoor, oorvra die Skrif. Die bedoeling van die Bybel is byvoorbeeld nie om (histories of wetenskaplik eksakte) informasie oor allerlei sake te gee nie. Die Bybel is nie 'n handboek vir geologie of kosmologie of die mediese wetenskap of fisika of noem maar op nie. Origines het byvoorbeeld al gewaarsku dat Gen. 1 nie eksakte historiese inligting oor die presiese, kronologiese ontstaan van die skepping wil gee nie, maar eerder 'n teologiese uitspraak wil maak: God, en nie die gode nie, het die hemel en aarde geskep. Net so het mense soos Augustinus en Calvyn al daarop gewys dat jy nie sterrekunde vanuit Bybelse gegewens kan bedryf nie, in elk geval nie as jy 'n goeie sterrekundige wil wees nie. Waarom nie? Omdat die Bybel - op menslike manier - in die taal en kontekste van sekere tye praat. Wie aller- 
lei informasie (of geheime kodes!) uit die Bybel wil aflees, mag dit dalk doen onder die oortuiging dat hulle "Skrifgetrou" wil wees, maar in werklikheid is bulle Skrifontrou, aangesien die unieke karakter van die Skrif nie eerbiedig word nie. Dan word dinge wat op die periferie lê tot die sentrum verhef. Dan word die Bybel oorvorder. Dan is dit net so goed asof jy - met respek gesê - vanuit 'n kookboek allerhande afleidings probeer maak oor hoe om 'n kernreaktor te bou! So 'n benadering mis die punt van die Skrif.

En wat is hierdie punt? Jy sou dit seker op baie maniere kon saamvat, maar na my mening hoor ons iets hiervan in 2 Tim. 3:15, waar Paulus vir Timoteus raad gee:

Jy ken van kleins af die beilige Skrif. Dit kan jou die kennis bybring wat tot verlossing lei deur die geloof in fesus Christus.

Die heilige Skrif waarvan Paulus hier praat, is nie die ganse kanon soos wat ons dit vandag ken nie - dié was nog nie saamgebundel nie - maar waarskynlik die Pentateug en die boek Levitikus. Hierin, sê Paulus, hoor ons reeds die boodskap van verlossing in Jesus Christus! Dít is die punt, die sentrum van die Skrif, en ek gebruik dit ook hier in 'n oordragtelike sin, in terme van die Ou en Nuwe Testament. Jy sou dit ook anders kon sê: die boodskap van die Bybel is dié van die verlossende handelinge van die Drie Enige God, veral soos dit blyk in fesus Christus (vgl. weer 3.5.1.1). Daarom kan Paulus ook sonder skroom aan die Korintiërs sê:

Ek bet my voorgeneem om met julle oor niks anders te praat nie as oor fesus as die Christus, en wel oor Hom as die gekruisigde (1 Kor. 2:2).

Dit is alleen vanuit hierdie sentrum dat ons bogenoemde vier kenmerke van die Bybel as Woord van God kan waardeer. Die Bybel dra gesag, maar nie as dit kom by uitsprake oor sterrekunde of argeologie of fisika nie, maar wel as dit handel oor hierdie unieke boodskap: God maak verlossende bemoeienis met die mens. Die Bybel is noodsaaklik, want nêrens elders in die wêreld, nie in enige ander boek, word die boodskap van God se genadige ingrype só vertel as juis in die Bybel nie. Die Bybel is duidelik, is in 'n sekere sin glashelder, nie omdat dit foutloos praat oor dinge soos medisyne of kernkrag nie, maar omdat dit 'n boodskap van verlossing verkondig, wat, hoewel dit veelkleurig is, ook eenvoudig is, só eenvoudig dat 'n kind dit kan verstaan. Ja, selfs die blindes kan tas dat die dinge wat in die Bybel voorspel is, plaasvind (NGB 5). Die feit dat daar dikwels so 'n verwarring oor die betekenis van die Bybel is, het meer te make met óns oogklappe, óns ingewikkeldheid, as met die eenvoud van die Bybel. Ons het inderdaad genade nodig om dit te (begin) verstaan! 
Die Bybel is ook genoegsaam, dis volmaak. Niks meer is nodig nie. Daarin het God sy hart uitgepraat. En sy hartswoord lui: Want so lief het God die wêreld gehad...

Hierdie boodskap kan net in die geloof aanvaar word. Die bedoeling van die Bybel is nie bloot dat ons dit sal analiseer en dissekteer as linguistiese of historiese fenomeen nie - hoewel dit, soos ek reeds gesê het, nie onbelangrik is juis vir die verstaan van die boodskap nie - maar die bedoeling van die Bybel is veral om gehoor en gehoorsaam en gelééf te word. Uiteindelik het dit weinig sin vir 'n dorstige om die put met water in die woestyn vanuit 'n wetenskaplike hoek te bevraagteken (watter argeologiese strata het dié verskynsel tot gevolg gehad? Presies hoe is die $\mathrm{H}_{2} \mathrm{O}$ hier onder die aarde gevorm?). Eerder moet die dorstige daarvan drink - en leef.

\subsection{Implikasies vir die prediking}

Wat het dit nou alles te sêvir die prediking van die Woord? Ek maak voorlopig die volgende afleidings:

- Predikers mag nooit agter 'n sekere siening van die Bybel as "onfeilbare Woord van God" skuil en dit as 'n sjibbolet gebruik om eksegeties lui te word nie. Om te preek, is harde (wetenskaplike, eksegetiese, linguistiese, hermeneutiese) arbeid aan die teks. Maar in dié sin is dit ook 'n ontdekkingstog, open dit moontlikhede om telkens weer nuwe dimensies in die teks te ontdek, nuwe wêrelde te betree, wat nie sonder die wetenskaplike arbeid aan die teks as menslike dokument sou kon gebeur het nie. Predikers mis gewoon baie as hulle met 'n Skrifbeskouing opereer wat hulle huiwerig mak om werklik met die teks as linguistiese fenomeen om te gaan - al word hierdie huiwering ook gebore uit 'n bepaalde respek vir die Goddelike aard van die Skrif.

- Wetenskaplike metodes mag juis nie op hulle beurt só krities en afbrekend met die Skrif omgaan, dat predikers hulle vertroue daarin verloor, of hulle verwagting prysgee dat God se stem inderdaad hier in die voeë van die teks mag opklink nie. Wetenskaplike metodes is hulpmiddels om die boodskap van die teks beter te hoor, nie muilbande wat die mond van die teks toebind nie. Om te preek, het jy wetenskaplike metodes nodig, maar jy preek nie wetenskaplike metodes nie.

- Predikers moet fokus op die sentrale, unieke boodskap van die Skrif, en hulle nie laat vaswikkel in allerlei (vernuftige) redenasies oor periferiese aangeleenthede nie. Die verskriklike moontlikheid bestaan trouens dat die eksessiewe belangstelling in periferiese aangeleenthede 'n (onbe- 
wuste) poging is om jou verleentheid met die skandaal van die sentrale boodskap te verberg. Dit ís moontlik dat predikers, terwyl hulle spitsvondig en gloeiend oor randverskynsels in spesifieke tekste debatteer, presies die teenoorgestelde kan doen en dink as wat die sentrale boodskap van daardie tekste van hulle vra. Daarom moet predikers veral ook daarop let dat hulle die sentrale boodskap van die Bybel (naamlik dat God mense uit genade red) nie met hulle preekinhoud of -styl dwarsboom nie. Predikers praat helaas dikwels só asof God nie 'n reddende, werklike teenwoordigheid is nie, asof Hy nie die Een is wat was, is en wat kom nie (vgl. 3.7 vir voorbeelde hiervan).

- Omdat die Bybel 'n boek is waarin God self in mensewoorde aan die woord kom, is die prediking van hierdie Woord nie bloot die deurgee van informasie oor die verlossing nie, maar deel van die verlossende handeling van God self. Die Woord - en daarom ook die prediking informeer nie bloot nie, dit performeer. Bekend is die uitspraak van Calvyn dat onder die woorde van die prediker ook die bloed van Christus op die hoorders drup, en die poorte van die paradys voor hulle oopgaan. Iets van die wonder van die Skrifgeworde Woord, ja, ook van die Mensgeworde Woord skyn af op die prediking: in die werklikheid van mensewoorde klink die werklikheid van God se Woord op. Hierin lê die hoop van die prediking (vgl. 2.3).

- Kortom: predikers moet dus die Skrif as menslike én goddelike dokument ten volle honoreer. Navorsing het getoon dat moralistiese prediking, interessant genoeg, juis hierdie verband uitmekaar haal. Trouens, van die tipiese kenmerke van die moralisme is óf 'n onthistorisering van die teks (dit wil sê om die Bybel te hanteer asof dit 'n tydlose versameling van woorde uit die hemel is), met gepaardgaande verskynsels soos allegorie, óf om juis die kernboodskap, ja, die teologie van die Skrif, naamlik die genadige handeling van God, te verantropologiseer, en in morele oproepe tot selfverbetering te verander (vgl. Greidanus 1970:85-86). In plaas van die evangelie word dan eerder 'n kontrolelysie vir innerlike, godsdienstige evaluering gebied. Maar dít kan niemand troos nie. Nie in lewe nie, en ook nie in sterwe nie (vgl. verder 4.7 vir voorbeelde van 'n moralistiese misbruik van die Skrif).

Uit dit alles word opnuut duidelik: die Skrif is 'n skat wat die Here van die kerk aan ons gegee het. Dit bevat die woorde wat lewe gee. Die Gees werk daardeur. As ons predikers wil wees of word, ja, as ons íets van die geheim van die prediking wil verstaan, sal ons die kuns moet leer om werklik na hierdie Skrif te luister... 


\subsection{Die geheim van die prediking: om na die stem van die teks te luister}

\subsubsection{DRONK VAN TROOS...}

'n Enkele komma uit die Bybel. Dis soms al wat nodig is om 'n mens se lewe - en die gang van die kerkgeskiedenis - in 'n nuwe rigting te stuur. Soos in die geval van Herman Kohlbrügge. Dis bekend dat hy 'n soort "tweede bekering" ondergaan het met 'n ontdekking wat hy in Romeine 7:14 gemaak het, waar die plasing van die komma ${ }^{15}$ hom tot die insig gebring het dat ook die wedergebore mens niks het om op te roem nie, en dat ook die heiligmaking 'n gawe van God is. Hy skryf dat dié komma hom "dronk van troos" gemaak het, en ook: "Ek weet nie of iets in my lewe my al meer aangegryp bet as toe ek hierdie komma gesien het nie." Dié insig (wat al op die 29ste Julie 1833 by hom begin wakker word het) loop uit op 'n merkwaardige preek, gelewer op 31 Julie 1833 in Wuppertal (vgl. Hesse 1935: 151).

Wie dronk van die troos is, kan nie anders as om daaroor te preek nie. Maar dan moet jy eers diep teue van die nuwe wyn van die teks drink. Moet jy let op elke beweging, elke intonasie, elke puntuasie van die teks. Moet jy die "Woord teen die lig" hou, soos die titel van die bekende preekreeks lui, totdat die Gees die wesenlike daarvan aan jou deursigtig maak. Dis 'n vaste vertrekpunt vir die prediking, wat nou al vanweë die belangrikheid daarvan 'n paar keer in hierdie boek herhaal is: wie nie met die teks werk nie, het niks om in die prediking te sê nie. Of, in die woorde van Karl Barth: "There is, therefore, nothing to be said which is not already te be found in the Scriptures." (1964:89).

\subsection{2 'N "ONGEPREEKTE BYBEL"?}

Bogenoemde vertrekpunt kan ook andersom gesê word: as die stem van die teks nie in die prediking gehoor word nie, ìs dit geen prediking nie: "Sermons not informed and inspired by Scripture are objects dislodged, orphans in the world, without mother or father." (Craddock 1985:27)

15 Die komma staan in die Griekse teks wat Kohlbrügge geraadpleeg het, ná die woord "vleeslik". In die NAV lui die teks: Ons weet tog die wet is Geestelik, maar ek is aards (OAV: vleeslik) en soos 'n slaaf aan die sonde verkoop. Hierdie doodsberig ("ek is vleeslik") was juis vir Kohlbrügge die goeie nuus van die evangelie, veral ook vir die (reeds) wedergebore mens. Omdat ek vleeslik en aan die sonde verkoop is, kan net God my in Christus heiligmaak. Hierdie beklemtoning van die objektiewe heilsfeite in Christus, tref 'n mens dwarsdeur die teologie van Kohlbrügge aan (vgl. De Jong 1972:323; ook Aalders 1976: 79 e.v.). 
Dit is 'n goeie vraag hoeveel preke daar nie in werklikheid gepreek en gehoor word wat weeskinders-sonder-teks is nie. Trouens, daar sou 'n saak daarvoor uitgemaak kon word dat 'n ontstellende persentasie van die huidige prediking in Suid-Afrika (in elk geval wat betref die prediking oor die radio, vgl. Cilliers 1996:11) as tekslose preke getipeer sou kon word. Die vraag is natuurlik: Wat presies ís Skrifprediking? Wat behels prediking wat "getrou is aan die Skrif"? Wat is die kenmerke daarvan? Hieroor is daar dikwels uiteenlopende menings.

Dis die moeite werd om na die opmerkings van Karl Barth in dié verband te luister. Hy onderskei vyf kenmerke van predikers wat hulle preke in die Skrif wil veranker. Aangepas en verkort klink dit so:

- Eerstens, om jou vertroue in die Skrif te stel, dit wil sê om oortuig te wees dat die Skrif genoeg het om te bied, en dat jy nêrens elders hoef te gaan soek na antwoorde vir ons lewensvrae nie. Indien jy telkens allerlei "praktiese instruksies" wil byvoeg, is jou vertroue in die Skrif onvolkome.

- Tweedens, om die Skrif te respekteer, in die sin dat jy dit met die afwagting lees dat hierin inderdaad antwoorde vir ons lewensvrae lê. Om die Skrif só te lees, is om soos 'n mens te wees wat stadig, skynbaar moeilik lees, wat die woorde prewelend uitspel, wat die ene oë is, wat verwonderd staan oor die ontdekkings wat jy maak.

- Derdens, om die Skrif met gekonsentreerde en nougesette aandag te lees, om by die betekenis daarvan uit te kom. Hierdie nougesette lees sluit in die eksegetiese, historiese en linguistiese arbeid aan die teks, maar ook die soeke na die teologie daarin, na die nukleus van genade, na "God's message for society."

- Vierdens, om jou eie vooropgesette idees telkens weer deur die teks te laat korrigeer. Want hierdie neiging sit in ons bloed: om ons geliefkoosde teologiese konstruksies, of ons ideologieë, subtiel of blatant op elke teks af te sjabloneer. Dan moet elke teks my siening van evangelisasie of sending of politieke geregtigheid buikspreek - tot vervelens toe.

- Vyfdens, om jouself voortdurend te laat meevoer deur die beweging van God se Woord. Die Bybel is nie bloot vir kognitiewe kennisname bedoel nie, maar nooi uit tot 'n ervaring van inspirasie deur die Gees. Ons het inderdaad nie bloot die teks as dooie letter nie; die Gees werk daardeur, waai daardeur - sodat ons telkens mag vra: Wat gaan die lewende God deur hierdie teks vir my sê (1964:89-92)?

Waarskynlik sou ons tussen verskillende vlakke van Skrifgeorienteerdheid of -gefundeerdheid moet onderskei. Daar is byvoorbeeld preke wat baie teksverse (dikwels op die klank af) kan aanhaal, maar dit nie noodwendig 
in die verkondiging ontsluit nie. Daar is preke wat die Bybelse teks in 'n afgeleide sin hanteer, dit wil sê die teks nie letterlik aanhaal nie, maar tog deurdrenk is van die gedage-inhoude daarvan. In hierdie preke is die teks dan nie meer as sodanig herkenbaar nie, maar sou ons tog kon sê dat die "boodskap" nog daar is, en dat die naelstring tussen teks en preek nog nie gekip is nie. Daar is preke wat sterk eksegeties met 'n teks kan werk, maar nie daarin slaag om die brug na die konteks van die gemeente te kruis, oftewel die teks verstaanbaar as evangelie vir die tyd te vertaal nie. Daar is preke wat "expository preaching" genoem sou kon word, waarin daar 'n vers-vir-vers uitleg van 'n sekere segment van die Skrif plaasvind, sonder dat daar doelbewus gesoek word na "toepassings", of waarin die toepassings uiteindelik maar as 'n soort haastige addendum ná die uitleg bygevoeg word. Net so is daar preke wat wil voorgee om die teks as basis te gebruik, maar ten diepste funksioneer die teks hoegenaamd nié in die preke nie, en is die Bybelse teks in werklikheid opsioneel en uitruilbaar blote dekor vir een of ander geestelike "boodskap". Sulke preke mag wel "Christelik" in 'n teoretiese sin van die woord genoem word, maar dit mis die spesifieke aanslag en unieke smaak van 'n bepaalde teks. Dat "Skrifgetroue prediking" 'n komplekse aangeleentheid is, is sondermeer duidelik. Dat die teks tóg wel op bepaalde momente deur al die versperrings heen breek, ja, dat die teks by wyse van spreke wraak neem op en in ons onbeholpenheid, is niks minder nie as 'n Godswonder.

Dis in elk geval duidelik: Daar is min dinge wat predikers se prediking so kleur - en verkleur! - as bulle Skrifbeskouing. As 'n minimum moet jy aanvaar dat die teks 'n stem hét, asook iets om te sê; moet jy glo dat die Bybelteks nie uitgeput raak en verflou namate dit gebruik word of die historiese afstand tussen teks en leser groter word nie. Die Bybel is immers nie bloot Woord van God in sy eerste gegewene nie, maar ook in elke repetisie daarvan. Dit word nie op een of ander wyse verswak deur repetisie om so minder en minder God se Woord te wees nie (Calvyn). Dit het (altyd) 'n vlymskerp stem, skerper as enige swaard met twee snykante, wat deurdring selfs tot die skeiding van siel en gees en van gewrigte en murg (Heb. 4:12). Dis die oorkonde van ons verlossing, en bied die moederspraak vir die prediking van die verlossing, en die lewe uit verlossing. Wie by dié moeder gevoed word, kan nie weeskinders op die preekstoel baar nie.

Dit wil voorkom asof die prediking inderdaad al hoe meer gevaar loop om nie meer Skrifprediking te wees nie. Daar is groot dele van die Bybel waarvan die stem nooit nie, of selde gehoor word. Die Bybel blyk tot'n groot mate 'n "ungepredigte Bibel" te wees (Bohren 1996: 92-94; ook 1971: 110 e.v.). Die dik stroom van moralisme wat steeds deur die prediking in Suid-Afrika loop, is onder meer 'n simptoom van die feit dat predikers die 
teks te gou verlaat, of dalk nog nooit werklik besoek het nie (vgl. Cilliers 1996:13,24). Dis byna 'n vaste reël: wie die teks verlaat, soek meestal na vinnige en werkbare skemas; hulle volg die weg van die minste weerstand, en skiet so die prediking van die teks, ja die evangelie van die teks, in die voet.

Ons word geroep om in die prediking "hard aan die teks te bly". Om in ons preekoorhaastigheid verlangsaam te word - op weg na, en op pad vanaf die teks. Om met die teks te verwyl, daarmee en daarin te kuier, totdat dit vir jou soos jou eie huis begin voel. Om só met die teks om te gaan, dat dit op weg saam met jou gaan, by jou bly "linger", nie as 'n platgestrykte cliché nie, maar as die vreemde, subversiewe Woord van God; dat dit in jou bly rondwoel, lank nadat jy die Bybel toegemaak het (vgl. Brueggemann 1989:7-11). Ons word geroep om die teks te besoek en te herbesoek, te kou en te proe, ook te herkou en te herproe. Wie nie tyd met die teks wil deurbring nie, dit dag en nag oordink nie (Psalm 1:2!), behoort ook nie ander se tyd op - en onder - die kansel deur te bring nie.

Om tyd met die teks deur te bring, om dit te herkou, was byvoorbeeld vir Luther 'n saak van lewensbelang. Hy sluit aan by die Bybelse metafoor van eet en die Woord inneem (vgl. bv. Amos 8:11; Psalm 19:11; Openbaring 10:10; ook Bohren 1986: 75 e.v.), en noem die herkouingsproses die wese van ware meditasie. Meditasie is die lees en weer-lees van die Skrif, is om die Woord in die hart te herkou (meditari porprie est ruminare in corde). So word die hart as 't ware die maag van die mensegees.

In hierdie daad van meditasie word beide die intellek en die emosie saamgevoeg om die Woord te verstaan en te verteer. Herkouing is nie bloot 'n kognitiewe aangeleentheid nie, maar ook 'n inneem van die Woord met gevoel (cum affecto). In die herhaling en herkouing van die Woord word die gevoel vir God verwek. Vir Luther is hierdie proses uiteraard ook Christologies bepaald: die ganse lewe en lyding van Jesus moet dag en nag stuksgewys in die hart opgeneem en herkou word - byna soos 'n sakramentele handeling - sodat die hart verwarm kan word, en krag en voeding (soetigheid) die mens ingegee kan word. Meditasie is dus 'n muntstuk met twee kante: ons kom in die teks in, en die teks kom in ons in.

Luther kon homself hieroor heel prakties uitdruk: dis nuttig om elke aand 'n teks in die nag saam met jou te neem, om dit in jou hart te herkou, sodat jy dit in die môre as nalatenskap van die aand weer in ontvangs kan neem, en in die lig van 'n nuwe dag se vars genade kan proe. Soms is dit nodig om 'n hele psalm, of 'n enkele psalmvers, vir 'n dag of 'n week lank te oordink en te herkou, totdat dit in jou weefsel opgeneem is en deel van jou bestaan geword het. Kortom, wie die Woord nie eet nie, kan ander ook nie daarmee voed nie (vgl. Meuser 1983:88). 
Die spiritualiteit van die prediker blyk dus nie net uit gebed in die algemeen nie (vgl. hieroor hoofstuk 6), maar ook uit die wyse waarop gebed in verband gebring word met die omgang met die Skrif. Wie die Bybelteks vryblywend wil lees, of bloot as 'n oefening om (preek)informasie te verkry, verstaan nie wat meditasie is nie. Wie die teks wil lees, moet kom soos vir 'n piekniek, vir die aansit vir 'n ete, met die verwagting van versadiging. Of: wie die teks wil lees, moet oop wees vir die "emosie" daarin, die bui ("mood"; vgl. verder 4.6.4) - en dit het niks met sentimentaliteit te make nie. Wie die teks wil lees, moet gereed wees om trane daaroor te stort, om te kla saam met die litanie daarin, maar moet ook gereed wees om daarmee saam te dans, in ritme met die melodie daarvan. Wie die teks wil lees, moet in elk geval weet: in hierdie teks sterf en leef ek.

Die atmosfeer en styl, die geladenheid en "aura" van die Bybelteks moet elke woord en handeling, elke stilte en beweging, kortom elke moment en onderdeel van die preek en erediens deursuur en deurdring soos wat water 'n spons deurdring. Wie byvoorbeeld Psalm 130 voorlees, mag dit alleen maar doen as iemand wat self uit die dieptes na God roep, sodat die voorlesing - en prediking - self 'n stem uit die dieptes word, 'n stem wat só in die midde van die gemeente opklink dat die gemeente, en veral diégene wat in die dieptes is, daarmee kan identifiseer. Of: wie Psalm 88 voorlees en daaroor preek, kan dit beswaarlik doen as hy of sy nie weet wat dit is om op die rand van die graf te huiwer nie. Of: wie oor Psalm 100 preek, en nie uit eie ervaring weet hoe die trou van God jou tot barstens toe met vreugde en nogmaals vreugde kan vervul nie, moes eerder maar die mond gehou het.

Die punt is: die preek en erediens mag nie die Bybelteks kruisig nie; die Bybelteks moet die preek en erediens deurkruis. Wat nodig is, is deurKruis-de preke en eredienste (Bohren). Veral moet ook die styl van die liturg, sy en haar persoonlike aanslag en individualiteit, selfs sy en haar intonasie, liggaamshouding en maniërismes in diens van die styl van die Bybelteks, en so van God self te staan kom, deel word van die uitwysing van God op die kansel, die uitwysing van die Gekruisigde wat die sonde van die wêreld wegneem...

Die vraag is egter nou:

\subsubsection{HOE LEES PREDIKERS DIE BYBEL?}

As gereformeerdes bely ons: sola scriptura, en daarby ook nog: tota scriptura (net die Woord, die totale Woord). Hoeveel daarvan in die praktyk van die preekmaakproses tereg kom, is 'n ander vraag. Net al op 'n eerste vlak word hierdie vraag krities: hoe lees predikers die Bybel? Augustinus het die opmerking gemaak dat die voortdurende lees en herlees van die Skrif, totdat jy 
deurdrenk is daarvan, een van die primêre roepings van predikers is (vgl. Van Oort 1991:15; ook 1989:26). Dit vorm volgens hom trouens 'n onmisbare voorwaarde vir die hele bediening. Hierdie lectio divina is 'n eerste, "naïewe" en daaglikse lees van die Skrif, totdat jy vertroud is met die groter lyne, die omvattender verhaal van God se handelinge met mense. Augustinus het vroeg al 'n basiese probleem rakgesien: daar is te veel predikers wat tekste wil oppik, soos hoenders mieliepitte oppik, hier en daar en los en vas, sonder 'n aanvoeling vir die werfruimte van die Groot Verhaal. Die gebruik van 'n leesrooster het wel die voordeel dat dit hierdie willekeurigheid ten minste tot 'n mate uitskakel, maar het ook ander nadele (vir 'n kritiese bespreking, vgl.Van der Walt en Du Toit 1999:112119).

Die gedissiplineerde lees van die Bybel is 'n homiletiese (en geloofs!) onverhandelbare. Dit kán nie vermy word nie. Jy gaan nêrens begin, as jy nie êrens begin nie. Dié naïewe lees van die Bybel gaan aan die eksegetiese arbeid vooraf, en moet as 't ware die bedding skep waarbinne die eksegetiese arbeid en trouens die hele preekmaakproses kan verloop. Volgens Bohren verkry die Skrif sy stem in die lees daarvan, en hierdie stem vorm weer in ' $n$ sin die voorveronderstelling en doel van die teologiese arbeid (1996:85). In hierdie leesproses word die krag van die Skrif om self sy weg na ons toe oop te praat, vertrou. Die Skrif het sy eie ritme, sy eie polsende energie. Om 'n kontemporêre beeld te gebruik: teksverse is soos golwe wat breek, en lesers en predikers moet leer om soos goeie branderplankryers in die momentum daarvan te kom, om die kruin te ry. Dat dít nie so 'n maklike kuns is nie, sal nie net ervare branderplankryers/predikers jou kan vertel nie. Dikwels is meer as een onderdompeling nodig voordat jy jou voete op die branderplank/kansel vind!

Die uitgangspunt is: die Skrif het sy eie werking en helderheid, nie net in die private lees daarvan nie, maar ook wanneer dit in die erediens voorgelees word. Laasgenoemde is volgens Augustinus reeds verkondiging van die heil - sonder dat enige preekkommentaar daar by hoef te kom. Dit mag na 'n vanselfsprekendheid klink, en tog bly hierdie vraag prinsipieël: hoe lees predikers die Bybel - indien wel? DL Moody se opmerking aan lidmate kan dalk ook predikers hulle leesgewoontes in heroorweging laat neem: Lees jou Bybel aan stukke...

Feit is: Jy kan nie preek as jy nie kan léés nie. Jy kan ook nie preek as jy nie kan lúister nie. In hierdie lees-en-luister-proses word al jou sinne opgevorder - oë, ore, gevoel, reuk, smaak, hart, verstand en verbeelding (vgl. Bugg 1992:68-76). Wie werklik lees, word in 'n nuwe wêreld ingebring, 'n wêreld waarin jy met verskerpte sinne waarneem, ja, waarin jy proe dat die Here goed is (vgl. 1 Pet. 2:3). Die lees van die teks is die poort na die alternatiewe wêrelde van die teks, en so van die evangelie self. 


\subsubsection{DIE GENRE VAN DIE TEKS: BRON VIR KREATIEWE PREDIKING}

Die vraag na die funksionering van die teks in die preekmaakproses is egter ook op 'n tweede vlak krities. Normaalweg is predikers op soek na die "boodskap" van die teks vir die prediking. Dis goed so. Solank ons net verstaan dat jy nie die boodskap of inhoud van die vorm van die teks kan abstraheer nie. Eugene Peterson praat van 'n "contemplative exegesis" en beskryf dit só: "Contemplative exegesis means listening to the word as sound, the word that reveals out of one's interior; it also means receiving the words in the form in which they were given. For the way in which words are spoken is as important as what the words say." (1195:117). Eintlik kan jy nie oor 'n "tema" vanuit 'n teks preek nie. Die teks is nie soos 'n lemoen wat jy uitsuig om die sap (inhoud) te kry, om dan die skil (vorm) weg te gooi nie. Nee, die vorm is 'n aanbod; as geboekstaafde, kreatiewe vormgewing is dit dié bron vir kreatiewe vormgewing in die prediking.

Die histories-kritiese navorsing en die literatuurwetenskap is hier van waarde: dit help ons om die verrassende wendinge, die nuanses en bewegings van die teks beter in die oog te kry en vir die prediking te benut. Hoewel hierdie wetenskappe nooit die verantwoordelikheid om oor die teks te mediteer mag verdring nie, kan die prediker tog ook nie met behoud van 'n goeie gewete daarsónder nie. Dit beteken nie dat elke metode wat daar is, onder die knie gekry moet word, of dat alle hipoteses goedsmoeds aanvaar moet word nie, maar wel dat hierin 'n potensiaal gegee is wat krities ontgin kan word (vgl. Bohren 1971:77 e. v.).

Dit alles bevestig maar net weer dat ons in die prediking nie genoeg erns met die Bybelse teks kan maak nie. Die teks vra dat ons met groot aandag daarna sal luister, dit sal bestudeer, daarmee sal worstel... gebroke, kreupel, deurdrenk met gebed... die nag in. Die boodskap van hoop is immers daar-binne ingebed, en bly roep om ontdekking en ontginning. Die kuns van die prediking lê in die oorvertelling, die verder vertelling van dié boodskap van hoop (vgl. 3.5.1.4), en dit kan op geen ander wyse gebeur as vanuit 'n konsekwente toewyding en arbeid aan die teks nie. Die teks - waardeur die Gees werk - is in 'n sin ál wat ons het. Maar dis genoeg.

Hierdie konsekwente toewyding aan, en luister na die teks, beteken dat ons nie alleen sal luister $n a$ die teks nie, maar ook dat ons as 't ware $i n$ die teks sal kom, om deur die teks na God se nuwe wêreld te kan kyk. "Predikers moet nie net in die teks sien nie en daar probeer inkom nie; bulle moet ook leer om deur die teks te kyk na die wêreld wat uitdy voor die teks. Hulle moet leer om 'n ander wêreld, 'n alternatiewe wêreld te sien, God se totaal anderse wêreld, God se hoopgewende redding en versorging van die wêreld ... so bring die kyk deur die teks wêrelde bymekaar: God se wêreld en ons wêreld." (Müller aangehaal in Cilliers 1998:1). Hierdie proses sou ten minste die volgende ses sake moes insluit: 
- Om in die prediking te bly in die fundamentele kode van die teks (byvoorbeeld om nie die saligsprekinge in 'n lys vermaninge te verander nie!). Daar is altyd sekere kodes in die teks soos metafore, beeldspraak en werkwoordvorme en -reekse wat ons nie moet miskyk nie. Om die een voorbeeld van die werkwoordelike vorme uit te lig: Dit gebeur dikwels in preke dat die verkondiging van heilsfeite subtiel verander word in heilsmoontlikhede, dat die verlede tydsvorm 'n futurum word - wat as wet deur mense vervul moet word. Van die hoorders word dan verwag om só op te tree dat heilsmoontlikhede in heilsfeite omskep word. Maar daarmee is die troos van die evangelie weg. Daarom moet ons telkens die teks fyn in die oog kry, telkens op die fynste besonderhede let, om die hoop wat in sulke verrassende wendinge skuil, ten volle vir die prediking te ontgin.

- Om in die prediking te let op die rol van metaforiese taal as herbeskrywing van die werklikheid, in plaas van 'n blote moralistiese etisering daarvan. Hierin bied die metafore van die Skrif aan ons 'n magtige voorbeeld dink maar net aan die aangrypende metafore wat deur die profete oor Israel uitgespreek word, en só 'n nuwe droom, 'n nuwe visioen by hulle skep. Om weer net een voorbeeld te noem: wanneer Esegiël sy visioen van die doodsbeendere wat lewend word aan die volk oordra (37:1-14), is dit gevul met die hoop van 'n nuwe begin, 'n egte verandering - wat deur die Gees van die Here self bewerkstellig word. Hoe soek ons nie in Suid-Afrika na sulke hoopgewende metafore nie!

- Om in die prediking aandag te gee aan die die rigting of trajeksie van die teks, dit wil sê om ook in die prediking uitvoering te gee aan die bedoeling of intensie van die teks. Hierdie stilstaan by die intensionele beweging van Bybelse tekste, beteken om telkens te vra: waarheen wíl hierdie teks? Wat wil dit doen en bereik? Daar is immers 'n sekere rigting in die teks en die teks wil 'n sekere gebeure ontlok. Betekenis hoop - word gegenereer deur die retoriese beweging binne die teks sowel as die beweging van die teks binne die gemeenskap wat daarna luister. Want, dit kan ons maar glo: die diepste bedoeling van Bybelste tekste is hoopgewend. Is om mense - die volk van God - te verander. Selfs al praat die teks van ons sonde of van God se oordeel. Uiteindelik wil die teks ons troos met die verlossing van die evangelie, al neem hierdie trooswoord verskillende gestaltes aan, en vertoon dit 'n verskeidenheid van gesigte. Hierin lê die teologiese swaartepunt van die teks. Die kuns van die prediking is juis om die spesifieke teologiese troosbedoeling van die teks te vind, en dit so getrou, maar ook so kreatief as moontlik oor en verder te vertel.

- Om in die prediking erns te maak met die sosiologiese lees van die Bybelteks, dit wil sê met sy spesifieke historiese, literêre, geografiese en sosio- 
ekonomiese plasing (Sitz im Leben). Bybelse tekste het nie uit die hemel geval nie, maar het ' $n$ bepaalde verlede. Dit is insiggewend dat moralisme feitlik altyd oor die historisiteit van die Bybelse teks wil spring, om by een of ander geabstraheerde "geestelike waarheid" of "wet" te kom. Moralisme teer trouens op die onthistorisering en vergeesteliking van die Skrif - en die gevolglike eksemplariese hantering daarvan (vgl. Cilliers 1996:25 e.v; ook verder 4.7). Wie egter nie eerlik met die verlede van die teks omgaan nie, sal ook nie die hede en die toekoms daarvan verstaan nie.

- Om in die prediking ' $\mathrm{n}$ verbeeldingryke antisipasie te ontwikkel met betrekking tot die "toepassingsmoontlikhede" van die teks, eerder as 'n droë, steriele toepassing, dit wil sê om die aanhakpunte tussen teks en lesers raak te sien en te ontgin, en om die teks te lees met 'n bouding van verwagting dat selfs die skynbaar bekendste of oninteressantste teksgedeelte ' $n$ vars woord van genade vir die prediking inhou (vgl. Wilson en Gaventa 1998: 397-401). Die atmosfeer van verwagting is die teelaarde van wonderwerke! Die teks hou inderdaad die belofte van 'n nuwe toekoms in - 'n toesegging van God se verrassende genade. Hoopvolle predikers is in dié sin kreatiewe predikers, dit wil sê mense wat só in die wêreld van die teks leef, maar ook só in die wêreld van mense leef, dat hulle nuwe verbindings kan lê, verrassende assosiasies wat meebring dat daar nuwe moontlikhede gesien kan word waar daar voorheen geen sigbaar was nie (vgl. Cilliers 1998:97 e.v.). Kreatiewe predikers is mense wat egter ook weet dat hulle nie sonder die kreatiewe Gees kán preek nie, en daarom bly bid: Veni, Creator Spiritus, kom, Skepper-Gees (vgl. Cilliers 2000: 121-122).

Die verstaan van die wêrelde agter, van en voor die teks help ons om beter agter die kap van die byl, oftewel die swaai van die swaard van die teks te kom (oor die bydraes van Ricoeur in dié verband, vgl. Vos 1996: 58-78; ook die helder uiteensetting van Dirkie Smit 1987). Hierdie navorsingsmetodes mag egter nooit, soos ek reeds gesê het, as 'n doel in hulleself beskou word, of predikers só onseker ten opsigte van of sinies teenoor die teks stem dat hulle hul inspirasie vir die prediking verloor nie. Die ou wysheid van Augustinus is dalk weer van pas: die hulpwetenskappe mag wel benut $(u t i)$ word, maar net die evangelie mag geniet (frui) word (Van Oort 1989:8)!

Om 'n enkele voorbeeld uit die oeuvre van die taalwetenskap te noem: Homilete begin al hoe meer verstaan dat daar 'n duidelike verband tussen die literêre genre van die teks en die prediking is. Wie sensitief is vir die genre van die teks, vra ander soort vrae aan die teks, benader dit met 'n ander tipe verwagting as wat bloot in 'n kliniese soektog na die "boodskap" 
van die teks die geval sou wees. Die opmerkings van Long is kenmerkend van só 'n ruimer benadering:

- Laat die beweging (“movement") van die Bybelteks die beweging van die preek bepaal

- Laat die opponerende kragte van die Bybelteks die opponerende kragte van die preek word

- Laat die sentrale insig van die Bybelteks die sentrale insig van die preek uitmaak

- Laat die bui ("mood") van die Bybelteks die bui van die preek kleur (1996: 127-135)

Hierdie benadering tot die Skrif verskil hemelsbreed van dié van die fundamentalisme. In laasgenoemde word onder meer die historiese en linguistiese aard van die Skrif tot 'n groot mate buite rekening gelaat - met verreikende gevolge vir die prediking. Daar is trouens min dinge wat kreatiewe vormgewing in die prediking so smoor soos fundamentalisme. Wie die unieke historiese en literêre aard van die teks, kan ek maar sê, die menslike aard daarvan, misken, en te gou soek na "tydlose waarhede" wat op een of ander wyse in die teks verborge sou wees, verstaan na my mening nie wat sola scriptura en tota scriptura beteken nie. Die teks is vól retoriese en kommunikasiestrategieë, vól verhaalverrassings - wat wag om ook in die prediking ontgin te word. So 'n benadering is iets totaal anders as om 'n vaste skema op elke preek af te druk, sodat die gemeente later klaar weet wat kom volgende ("ek weet al wat die dominee gaan sê voordat hy/sy dit sê”). Trouens, sommige predikers saboteer eksplisiet die verrassinge van die teks en preek: hulle sê vir die gemeente wat hulle gaan doen (3 punte!), dan doen hulle dit, en dan sê hulle samevattend (of hulle herhaal dit in die gebed) wat hulle gesê het hulle sal doen en toe gedoen het. Geen wonder dat preek en verveling vir baie al sinonieme geword het nie.

Nee, die verveeldheid moet ophou, trouens, as daar één intoleransie is wat Christelik is, is dit die een teen verveling (Bohren 1971:404). Om Bybelse tekste te lees en daaroor te preek, is opwindend, is 'n ontdekkingstog, is ontdekkingsvreugde (Barth). Dis musiek vir die ore. Volgens Mike Graves is preekmaak letterlik om soos 'n komponis én 'n dirigent te wees! Die uitdaging is om nie bloot informasie of 'n morele les uit 'n Skrifgedeelte oor te dra nie, maar eerder: "to communicate the experience of a passage. This kind of preaching, like a touching piece of music, comes through the gut more than through the mind." (1997:10) Hiervoor moet die prediker volgens hom die genre van die teks verdiskonteer, moet daar fyn geluister word na die teks, na die "mood" en die "movement" daarvan (vgl. 
ook Buttrick: 1987). Die "mood" is die emosie ("state of mind or feelings") wat die teks by ons oproep, en die "movement" die progressie, struktuurpatroon en gedagte-verdeling van die teks (Graves 1997:12). Soos 'n komponis moet die prediker na die beste musiek soek om die teks uit te voer, en as dirigent moet die prediker dit dan ook met die mees geskikte instrumente op die planke bring. Die prediker moet as komponis-dirigent na woorde en beelde soek wat die woorde en beelde van die Skrif tot hulle reg laat kom, altans volgens die interpretasie van die prediker. Die prediker kies 'n bepaalde toonsetting, kies dinamika in woorde en stemgebruik (18 e.v.).

\subsubsection{BYBELSTE TEKSTE: VENSTERS OP DIE GESIG VAN GOD}

Die tegniek van die komponis-dirigent mag egter nooit 'n doel op sigself word nie! Bybelse tekste is ook nie net retories aangrypend of literêr mooi ter wille van die kunssinnigheid daarvan nie. Bybelste tekste vertel die verhaal van God, en is as sodanig op sy openbaring gerig. Die punt is: op jou ontdekkingstog deur die wêreld van die teks, in die tekstuur en weefsel (texere) daarvan, loop jy 'n kans om die lewende stem van die evangelie, die viva vox evangelii te hoor. In die beddinge van die teks kan die voetspore van die Gees, ja, die voetspore van God gevind en gevolg word. Elke teks open nuwe wêrelde, verrassende moontlikhede, ongekende beloftes, naamlik dié van die evangelie. Bybelse tekste is in-lokkend. Dit spel die evangelie uit, nooi ons in na 'n wêreld waarin ons kan sien hoe God werk. As evangelie spel dit tegelykertyd die bevryding uit tot 'n nuwe lewenswyse. In bekender terme gestel: die teks verkondig die indikatief as imperatief, en die imperatief as indikatief. En die geheim van die prediking is om dít te ontdek en hierdie ontdekking met die gemeente te deel (vgl. Cilliers 2000:21-33).

Grondliggend vir die prediking is dus die vraag: wat ís 'n (Bybel)teks? Ons sou kon sê: elke teks is 'n venster, wat 'n unieke visie op die gesig van God oopmaak. Meer nog: elke teks is 'n veelheid van vensters, is 'n kaleidoskoop van insigte, van nuwe perspektiewe op die gesig van God. Tekste bevat, soos ek reeds beklemtoon het, as sodanig meer as een waarheid oor God; meer as een interpretasie is daarom nie net moontlik nie, maar gewens. Wie 'n teks lees met die oog op die distillering van 'n enkele, “ewige waarheid" daaruit, loop gevaar om die teks te versmal en uiteindelik te bederf. Wie tevrede is om één diamant op die delwersif van die eksegetiese arbeid te ontdek, het nog nie diep genoeg in die myn van die teks gedelf nie. Of, wie net bly staar na één kant van die diamant, en dit nie telkens in die prediking in die rondte draai nie, sal nooit die volle vonkeling daarvan ervaar nie. Jy kan die skat in jou hand hou, sonder om die rykdom daarvan te verstaan. Net so kan 'n goeie teks blykbaar in die hande van slegte mense 'n 
slegte teks word, en 'n slegte teks in die hande van goeie mense 'n goeie teks (Rabbi Tzvi Marx). 16

Die roeping van predikers is om in die prediking telkens 'n nuwe kant van God se gesig, 'n nuwe perspektief op sy genadige teenwoordigheid aan die gemeente te bemiddel. Dít kan egter nie gedoen word sonder dat daar deur die bril van die Skrif gekyk word nie. Dis alleen wanneer die lens van die Skrif, die spesifieke lens van 'n spesifieke teks ons oë fokus op 'n spesifieke openbaring van God, dat ons as predikers ander kan uitnooi om saam met ons deur dié lens te kyk. Trouens, die sin van die prediking is juis om as gemeente deur die teks heen 'n nuwe perspektief op God te verkry, en daarom ook op onsself en die wêreld waarin ons ons bevind (vgl. hoofstuk 3).

Hierdie perspektief is presies dit: 'n perspektief, 'n hoek van visie, 'n waarneming vanuit die plek waar jy staan. Dit kan dus nie ánders as om kontekstueel te wees nie. Dit kan ook nie anders as om eksperimenteel te wees nie, in dié sin dat jy voortdurend weet dat daar ook ánder perspektiewe, ánder interpretasies van hierdie openbaring van God moontlik is. Daarom is elke perspektief, elke preek juis ook beperk, en moet dit ook nie voorgee om die volle prentjie van die volle waarheid aan die gemeente voor te hou nie. Preke is stukwerk, is fragmente, en as sodanig oop uitnodigings dat ander ook met vrymoedigheid húlle perspektiewe deur die lens van die teks mag verwoord. Preke staan onder 'n eskatologiese voorbeboud: Want ons ken maar gedeeltelik, en ons verkondig God se wil maar gedeeltelik, maar wanneer die volledige kom, sal wat gedeeltelik is, uitgedien wees (1 Kor. 13:9, 10).

Maar die wonder bly: God openbáár sy gesig aan ons. Hy práát deur die lewende stem van die teks.

Genoeg om dronk van troos te raak.

\subsubsection{BYBELSE TEKSTE: BRÛE WAT WÊRELDE VERBIND}

Kom ons spel weer die implikasies uit van alles wat tot dusver in hierdie hoofstuk gesê is, vanuit 'n ander hoek. Die prediking is vir baie lank tradisioneel beskryf as 'n beweging "van teks na preek" (vir literatuur, asook kritiek daarop, vgl. Bohren 1974:143 e.v.). Die basiese gedagtegang hieroor was op die oog af eenvoudig, en min of meer soos volg: tussen die antieke Bybelse teks en die huidige hoorder of leser gaap 'n eeue-oue kloof, wat so goed as moontlik deur die prediker oorbrug moet word. Dit word gedoen deurdat die prediker met korrekte eksegese die sentrale boodskap of tema van die teks moes vasstel, en dit met so min inmenging (inlegkunde) as moont-

16 In 'n ongepubliseerde referaat, gelewer by die konferensie van die Societas Homiletica in Doorn, Nederland (16-21 Junie 2001). 
lik na die hoorder oordra, en in die proses ook voorsien van 'n gepaste toepassing. Dikwels was hierdie applicatio niks anders as 'n gedwonge analogie tussen historiese en kontemporêre situasies nie, in die trant van: "Ons is ook maar net soos Petrus van ouds, nie waar nie?, of: "Ook vandag nog worstel ons net soos Paulus teen die vyande van die evangelie." Maar, ten spyte van al die kontinuitteite wat daar tussen sekere historiese situasies mag bestaan, is dit tog duidelik dat daar veel meer diskontinuiteite is, of dat die diskontinuïteite ten minste net so treffend of opvallend soos die kontinuïteite is. Die verloop van die geskiedenis is nie net volgens stringente lyne nie, maar veral ook volgens kontingente onderbrekings. Ons is nié "net soos" Petrus nie, en ons worstel nié "net soos" Paulus teen die vyande van die evangelie nie. Daarvoor is die klowe van tyd, kultuur en konteks eenvoudig té groot (vgl. Cilliers 1994:19 e.v; ook verder 4.8).

Wat bogenoemde manier van prediking nog meer twyfelagtig maak, is die stereotiepe moralistiese toevoeging wat gewoonlik daarmee gepaardgaan. Dan word die preek 'n tydlose drie-stap oefening, 'n geykte uiteensetting van beginsel, toepassing, en natuurlik, vermaning (vgl. Cilliers 1996:98). Iets soos:

- Vandag se teks sê vir ons... (reduksie van die teksbetekenis tot 'n algemene beginsel of waarheid)

- Toegepas op ons situasie beteken dit... (preskriptiewe toepassing van die waarheid op mense se lewens)

- Daarom moet/behoort ons... (vermaning tot nuwe optrede)

En tog is vir lank vasgehou aan hierdie paradigma, waarin die prediker as 't ware soos 'n skuba-duiker diep onder die waters van die geskiedenis moes induik, die kosbare koraal (of morele les!) moes vind, om dit so ongeskonde as moontlik bo die water uit te bring, en in die hande van die wagtende ontvangers te gee (Croatto 1987:66). Of, soos 'n chirurg wat die teks met steriele handskoene (korrekte eksegese, histories-kritiese metodes, ens) moes opereer, om tot die kern van die waarheid deur te dring (Long 1990:342; ook Peterson 1995:107 e.v.). Tekste is benader asof hulle geslote houers is wat oopgekraak moes word, om by die verborge diamant van geheimenis wat daarin weggesteek is, uit te kom.

Hierdie uitganspunt het egter al hoe meer in die spervuur gekom, om 'n hele reeks redes. Ek noem slegs drie (in aansluiting by Long 1990: 342-343):

- Eerstens: daar is lank nie meer eenstemmigheid onder Bybelwetenskaplikes oor wat dan nou die enigste of legitieme interpretasiemodel sou wees nie! Inteendeel, die denkrigtings in dié verband staan soms lynreg teenoor mekaar. 'n Konglomeraat van interpretasiemetodes is 
tans op die hermeneutiese horison te bespeur, byvoorbeeld dié van die feminisme, liberalisme, postliberalisme, postmodernisme, resepsieestetiese, ens. Hierdie verandering in die hermeneutiese landskap het sonder twyfel ingrypende invloed op die prediking: die pad "van teks na preek" is nie meer so bekend en helder verlig as wat voorheen veronderstel was nie.

- Tweedens: daar word al hoe meer aanvaar dat die histories-kritiese metode, trouens, álle metodes, nie neutraal is of kan wees nie, maar opkom uit bepaalde ideologiese voorveronderstellings in verband met die aard van betekenis. Die steriele handskoene was toe nié so steriel nie. Wat egter nié beteken dat die prediker sónder 'n deeglike, wetenskaplike omgang met die teks kan klaarkom, en as't ware sonder die handskoene, of erger nog, met septiese handskoene 'n chirurgiese ingreep op die teks kan aandurf nie. Volgens Eugene Peterson behoort 'n prediker wat met sulke septiese handskoene (twyfelagtige metodes, gebrek aan metodes, gewoon eksegetiese luiheid) op die teks opereer, net so seker gedagvaar te word as wanneer 'n geneesheer dit sou waag om só op 'n pasiënt te opereer (1987:109-110)! Dis die uitdaging, die spanning van eksegese: die handskoene is nooit steriel nie, maar mag ook nooit septies wees nie!

- Derdens: die siening van wat die Skrif is, en hoe dit funksioneer, het verander. Saam met die verskuiwing in hermeneutiese paradigmas het daar 'n onvermydelike skuif in die Skrifbeskouing gekom. Dit is 'n feit wat fyn beoordeel moet word, aangesien hierdie skuiwe uiteraard nie net onvermengde seën meegebring het nie. Die grootste winspunt van hierdie skuiwe is na my mening egter die feit dat daar juis 'n nuwe belangstelling in die gegewene van die Bybelse teks ontstaan het, 'n herontdekking van die moontlikhede en die beperkings, juis ook in soverre dit die prediking raak. In die ou paradigma van die beweging van "teks na preek" het die teks - teen die bedoeling van predikers in - aan die kortste end getrek. Terwyl elemente of brokstukke van die teks ('n "boodskap", idees, temas) oor die brug gedra is, het die teks self agtergebly, dit wil sê die teks met sy literêre weefsel, vol retoriese wendinge en strategieë, maar ook in sy weerbarstigheid, sy oneffendheid. Brueggemann is waarskynlik rég as hy sê dat ons die teks tot 'n groot mate makgemaak het, dit gereduseer en getrivialiseer het (1989:7). Terwyl "mooi", en dikwels ook moralistiese boodskappe by wyse van gekunstelde historiese analogieë oor die kloof gedra is, het die teks agterweë gebly, is dit nie kans gegun om as teks uit te kon praat nie. Terwyl daar probeer is om die sap (inhoud) van die lemoen (teks) uit te druk, is die skil (vorm) agtergelaat - tot nadeel van die prediking (Long 1996:127 e.v.). 
Predikers se Skrifbeskouings het ongetwyfeld deurslaggewende implikasies vir hulle prediking. Of predikers hierdie feit nou eksplisiet verwoord, en uit hierdie oortuiging preek, en of dit meer implisiet agter hulle prediking lê, dié verband is daar, en kan gewoonlik ook uit die prediking afgelees word. 'n Analise van konkrete preke lê gewoonlik bloot watter Skrifbeskouing in hierdie preke virulent is - of nie (vir konkrete voorbeelde, vgl. Cilliers 1998:59 e.v.; ook 2000:56 e.v; ook verder 4.7).

\title{
4.7 Preekvoorbeelde van 'n mislukte (moralistiese) luister na die Skrif
}

\begin{abstract}
Die Woord van God is lewend en kragtig. Dit is skerper as enige swaard met twee snykante en dring deur selfs tot die skeiding van siel en gees en van gewrigte en murg. Dit beoordeel die bedoelings en gedagtes van die bart. (Heb. 4:12).
\end{abstract}

Só word die aard en werkkrag van die Woord deur die Skrif self gedefinieër. Die Skrif bevat die Woord van God, is die medium waardeur die Persoon van die sprekende God ter sprake kom. Die geheim hiervan is die Heilige Gees. Hy maak die letter van die Skrif tot lewende woorde, woorde wat oor tydsgrense heen die kerk van alle tye vergader, beskerm en onderhou het met die blye nuus van die evangelie. Die Gees laat die Woord wérk, maak daarvan 'n unieke Boek, anders as enige ander boek in die geskiedenis. Juis daarom kon die Reformatore - soos ons bo (4.3) beklemtoon het - onder meer praat van die outoriteit, noodsaaklikheid, duidelikheid en genoegsaamheid van die Skrif. Dit bevat alles wat nodig is vir ons om tot kennis van die waarheid en tot saligheid te kom, en spreek dit daad-werklik uit. Die Skrif het 'n uitvoerende (performatiewe) karakter.

Dis belangrik dat ons vir 'n oomblik by hierdie begrip stilstaan. Dit is oorspronklik deur John L. Austin gebruik in sy onderskeiding van beskrywende en uitvoerende (performatiewe) spraak (1972:125 e.v.). Beskrywende spraak definieër hy as tipies dié van die objektiewe waarnemer, as gevolgtrekkings wat geldig sou kon wees vir alle omstandighede, doeleindes en hoorders. Dit verteenwoordig 'n algemene beskrywing wat nie noodwendig op hierdie hoorders, nou van toepassing is nie. Daarteenoor staan die uitvoerende spraakvorm, wat Austin aan die hand van die sakrament van die doop illustreer, waartydens die prediker as bedienaar van die doop sê: "Ek doop jou in die Naam van die Vader, die Seun, en die Heilige Gees.” In hierdie uitspraak "sê" die prediker nie alleen nie, maar voer hy die doopdaad uit. Of, wanneer die regter sê: "Ek verklaar jou hiermee in die naam van die gereg skuldig", is hy nie soseer besig om oor die eienskappe van skuld en geregtigheid te 
praat nie, maar word dit eerder uit-gespreek, uit-gedruk. Die woord van die regter bring oordeel, of vryspraak, aan.

Volgens Austin word die uitvoerende spraakstyl die beste geillustreer aan die hand van die teenwoordige, indikatiewe, aktiewe spraakvorm (bv. "God is aan die werk."), hoewel hierdie vorm nie veralgemeen mag word nie en aangevul kan word met voorbeelde wat nie formeel in die indikatiewe aktiewe vorm voorkom nie. Tog bly die performatiewe vorm, gesien in die konteks van 'n hele teksstruktuur, 'n goeie aanduiding van 'n spreker se verwoording van die teenwoordigheid en handelinge van die gesagsinstansie of persoon van wie gepraat word, in die geval van die prediking: God.

God se uitsprake neem verskillende gestaltes aan, maar is altyd 'n uitdrukking van die een evangelie (vgl. weer die skematiese voorstelling by 2.5.3). Soms val die klem op die openbaarmaking van ons sonde, wanneer die evangelie tot ons kom as wet wat ons na Christus toe dryf (wet as usus elenchticus); soms val die klem op die dankbaarheid waartoe ons geroep word, wanneer die evangelie tot ons kom as 'n gebod of imperatief (paranese) of 'n konkrete riglyn vir gehoorsaamheid (wet as tertius usus). Dit bly egter deurgaans niks anders nie as die evangelie wat tot ons kom. Die blootleggende en oproepende gestaltes van die Woord is tuis in die huis van die evangelie. Daarin lê die belofteryke karakter van die Woord (promissio): dit vertel die storie(s) van God se groot dade, waarby die mens ook ingesluit word.

Hierdie basiese Reformatoriese perspektiewe op die Skrif sluit, soos ons reeds gesien het, die feit nie uit nie dat die Skrif tegelykertyd 'n waarlik historiese dokument is wat in terme van tyd ver van ons verwyder is. Die Skrif se uniekheid lê juis daarin dat dit tegelykertyd teologies én histories van aard is; dat dit die woord van God vir alle tye en daarom ook ons (post)moderne tyd bevat, terwyl dit tog grotendeels tydens die ystertydperk tot stand gekom het! In hierdie uniekheid van die Skrif lê egter ook die dilemma (uitdaging!) van die prediking. Hieruit spruit die grondliggende hermeneutiese vraag: Hoe moet die afstand tussen toe en nou oorbrug word?, of, soos dit dikwels in preke verwoord word: "Wat beteken bierdie teksgedeelte vir ons vandag?"

Dat hierdie inherente spanning predikers maklik tot wettiese oplossings kan verlei, blyk oorvloedig wanneer 'n mens analities na preke kyk. Op allerlei maniere word probeer om die brug tussen die geskiedenis en die hede ("ook vandag nog") te slaan, met verreikende gevolge vir die teologiese gehalte van die preke.

\section{Historiese ANALOGIEË}

Die eerste metode, waarna ek reeds kortweg in 4.6.6 verwys het, is voor die hand liggend, en word met verskillende grade van finesse beoefen. Dit 
bestaan uit die soeke na analogieë tussen die tyd waarin die Bybelteks ontstaan het, wat ook in die Bybelteks 'n neerslag gevind het, en die tyd waarin die hoorders tans is; die ponering van ooreenkomste, identifikasies, vergelykings en voorbeelde om as troos en appél vir die hede te dien. Die uitgangspunt is dat die aktualiteit van die Woord afhang van, of ten minste saamgaan met die moontlike ooreenstemming van historiese gebeure.

Die gebruik van analogieë in die prediking het natuurlik'n bepaalde reg. Dit moet egter deurgaans op 'n teologies verantwoorde wyse gedoen word. Greidanus wys byvoorbeeld daarop hoe maklik dit is om op ' $n$ arbitrêre en subjektiewe manier die komplekse aard van die geskiedenis, en die Skrif as 'n historiese dokumentasie van hierdie geskiedenis, met simplistiese tegnieke te probeer omseil. Eksemplariese prediking (wat altyd een of ander analogie as grondslag het) is volgens hom meestal 'n homiletiese kortpad by die historisiteit van die Bybelteks verby, met 'n hermeneutiese kortsluiting tot gevolg (1970:85-86).

Simplistiese gelykstellings ("Dit is vandag presies net só”) moet as 'n reël die homiletiese rooi ligte laat flikker. Staan die boodskap van die Bybelteks - teologies gesproke - nie juis teenoor ons (sondige) werklikheid nie? Moet ons nie juis in die prediking die teks téén ons hou, en vra: Waar is nie die raakpunte nie? Hoe pas die teks nie by ons in nie? As ons maar net met die teks saamstem, en die teks maar net by ons inval, is dit gevaarlik! Ons verkry tog juis nie 'n greep op die teks of God nie, maar andersom! Die teks het - soos ons bo aangetoon het - 'n weerbarstigheid, 'n ontembaarheid, 'n potensiaal om ons altyd weer te verras. Daarin lê juis die belofteryke aard daarvan!

Dit wil voorkom asof dit veral die sogenaamde "geleentheidspreke" is, waartydens sekere Bybels-historiese geleenthede herdenk word, wat ten prooi van die versoeking van moraliserende analogieë val. So hoor ons byvoorbeeld telkens in 'n Pinksterpreek oor Hand. 2:1-4; 11-18 dat die "belofte" van die uitstorting van die Heilige Gees "ook vanaand nog waar is", maar op so 'n wyse dat die uniekheid en heilshistoriese onherhaalbaarheid van die Pinkstergebeure in die slag bly. Die belofte moet homself net so herhaal, en die voorwaarde waarop hierdie presiese herhaling plaasvind, is die analoë handeling van die huidige hoorders met dié van die eerste Christene. Hierdie struktuur word reeds in die openingswoorde van die diens vasgelê:

"Dit is Pinkster. Ons vier vandag die fees van die uitstorting van die Heilige Gees. Dit was die begin van die kerk van die Here fesus en watter glorieryke begin was dit nie! As ons vanaand die tyd kon terugdraai en ons is almal so tweeduisend jaar terug daar by die kerk, dan dink ek sou ons baie opgewonde gewees het...Nou, die Here is nog dieselfde en ek is seker Hy wil vanaand in dié dae nog dieselfde doen." 
Die bedoeling van die prediker is duidelik: hy wíl inderdaad die tyd terugdraai, die tweeduisend jaar van kerkgeskiedenis sedert Pinkster ongedaan maak, die tyd van Pinkster en die van "vandag", "vanaand", "dié dae" laat ineenskuif, presies dieselfde laat wees. Die eerste Pinkster word die model vir kerkwees van alle tye, die onherhaalbare karakter daarvan (ephapax, eens en vir altyd) presies in die hede gerekonstrueer, sodat dit in 'n sekere sin 'n tydlose fees word. Die teologiese konsekwensie van hierdie veronderstelde en dwingende analogie is fataal, en die wettiese wending wat dit neem feitlik onvermydelik, soos blyk uit die slotsin van bogenoemde aanhaling: God "wil... nog dieselfde doen." Op Pinkster het God gedoen, maar nou blykbaar nie meer nie. Nou stel Hy dit maar net in die vooruitsig (soos 'n refrein loop die woordjie wil 18 keer deur die preek!) Waarom? Waarvoor wag Hy? . Die antwoord wat die prediker hierop veronderstel is, soos ons reeds in 3.7.2 gesien het, klassiek wetties, en lui hier: om te kyk of die huidige geslag Christene so kan handel soos die eerste geslag, of hulle daartoe in staat is om die analogie wáár en die tye presies dieselfde te maak, presies te laat oorvleuel! Wat voorheen 'n teologies bepaalde situasie was (God het gehandel en die eerste gelowiges het gereageer en getuies geword), word 'n antropologies bepaalde situasie (die huidige geslag handel, word getuies - en God reageer deur dit weer Pinkster te laat wees, presies soos die eerste keer). Daarom is dit heel konsekwent as die prediker verder in sy preek sy hermeneutiek in 'n (ietwat onsamehangende) sin soos die volgende verraai:

\section{"Só het sy kerk begin. Nie anders nie, maar net so...Die Here wil ons ook verander en sy kerk moet so wees. Dan word ons sy getuies."}

Dit staan in skerp kontras met'n Bybelteks soos Handelinge 1:8: maar julle sal krag ontvang wanneer die Heilige Gees oor julle kom, en julle sal my getuies wees. Let op wat hier gebeur: die teologiese orde (kode) van die teks word presies omgekeer Wat in die teks lui: God bet en ons kan \sal, verword tot God wil en ons moet. Daarom is dit juis so ironies as die prediker in die inleidende paragraaf sê: “...die Here is nog dieselfde en ek is seker Hy wil..." In die preek is God juis nie dieselfde nie (wat Hy gedoen het, verander in wat Hy sal doen), en word alle sekerheid op die losse skroewe van menslike handelinge geplaas. Die historiese indikatief word'n futuristiese imperatief - wat vervul word deur "ons" wat die opgawe het om Pinkster weer te laat realiseer.

\subsubsection{ANTROPOLOGIESE ANALOGIË̈}

'n Besonder geliefkoosde manier om die brug tussen die geskiedenis waarvan die teks vertel en die hede oor te steek, en 'n variant van bogenoemde, 
is by wyse van 'n antropologiese analogie, met die tipiese gepaardgaande allegorisering, atomisering, psigologisering, spiritualisering en tipologisering van die Bybelteks (Vgl. Greidanus 1970:85 e.v.). Figure uit die Bybel word as voorbeelde voorgehou wat nagemaak moet word (die sg. imitatio denke) en word 'n wet waaraan die geestelike kwaliteit van die hoorders getoets word. Die slagoffers van hierdie spesifieke soort wettisisme tel, onnodig om te sê, in hulle tienduisende.

Petrus word byvoorbeeld op hierdie wyse tot wet gemaak in 'n preek oor Matt.24:30. Eers hoor ons:

"...the central character of the story is none other than Fesus. The secondary character is Peter."

Dan volg 'n onthistorisering van die teks as die storm op die see voorgestel word as

"...the waves of humanity and...the billows of the chaos of everyday life."

Dit word begelei deur die psigologisering van die teks wanneer ons hoor:

"I think that this is because Peter speaks so silently yet so magnificently into our bearts and into our lives"

Wat weer uitloop op die onvermydelike moralisering:

"What Jesus has started in a person's life, He has the power to continue. If we only keep our eyes on Him...but also that we persist in steadily looking at Jesus, continuously, every moment of every living day of our lives, that we never take our eyes off Fesus..."

Hierin is Petrus vir ons die (negatiewe!) voorbeeld - hy het nie genoeg na Jesus gekyk nie. Ons moet hom troef. Ons moet nie faal nie, maar altyd sterk wees. Uiteindelik word Petrus so in die sentrum van aandag geplaas, dat dit geen wonder is dat die prediker homself weerspreek nie:

"As I said earlier on the two central characters within this story are the characters firstly of Jesus and secondly of Peter."

Die een sentrale karakter het nou inderdaad twee geword! Die preek eindig met 'n subtiele ommeswaai van die Bybelteks: nou is dit nie meer Jesus wat sy hand uitsteek en Petrus gryp nie, maar 
"let this be a turning point in your life where you stretch out your hand in prayer...And Jesus Himself will touch you again with His love..."

Ook die vrou wat aan bloedvloeiing gely het loop dieselfde homiletiese paadjie (Mark 5:25-34). Haar besondere geloof, haar "vonkie van hoop" word die spieël waarin ons die kwaliteit van ons geloof moet meet. Haar "probleem...haar geloof...haar vrees" dien as 'n eksistensiële analogie om die hoorders met hulle swak geloof op standaard te laat kom:

\section{"U moet dit net soos hierdie vrou glo....U moet vanmôre meer soek. U moet fesus nie net soek vir tydelike bevryding nie, maar u moet Hom soek as 'n ewige skat in u lewe."}

Keer op keer hoor ons: "En so...moet julle".

\subsubsection{KENMERKENDE RETORIESE TEGNIEKE}

Dikwels word die brug tussen die boodskap van die Bybelteks en die reaksie wat die prediker van sy hoorders verlang met behulp van kenmerkende retoriese tegnieke oorgesteek, tegnieke wat as sodanig seker nie verkeerd is nie, maar in die wettiese raamwerk waarbinne dit funksioneer 'n homileties degraderende funksie vervul. Dit is ook meestal tegnieke wat glad nie uit die struktuur van die Bybelteks (waaraan die prediker eerder hard moes bly werk het) afgelei kan word nie. Moontlik is dit 'n uitdrukking van die prediker se (onbewustelike) aanvoeling dat sy of haar homiletiese metode nie reg laat geskied aan die performatiewe karakter van die Bybelteks nie, en nou op een of ander wyse "aangevul" of "versterk" moet word.

\subsubsection{Retoriese vrae}

Heel eerste in die ry staan die gebruik van retoriese vrae. Die prediker het 'n visie van wat God in die Bybelse tyd gedoen het, en wil graag sien dat sy of haar hoorders so optree of so word soos die mense met wie God gehandel het. In plaas daarvan om God se handeling (opnuut) uit te spreek, word oorgegryp na wat mense nou behoort te doen, word hulle met behulp van inkwisitatoriese vrae op hulle tekorte gewys, met die veronderstelling dat hulle dit nou self kan en behoort aan te vul. Vrae van dié aard word gewoonlik in die slotparagrawe van preke opgestapel, as 'n tipe kontrolelys vir selfondersoek. Die frekwensie waarmee hierdie retoriese tegniek gebruik word, is van so 'n aard dat dit voorkom asof predikers byna aan 'n neurotiese soort angs ly om die gemeente tog net nie met leë hande huis toe te stuur nie, om tog iets konkreets aan hulle te gee om met hulle op die 
weg deur die lewe te neem - asof die evangelie nie genoeg is nie! Asof die Woord nie te vertrou is nie!

'n Enkele, besonder uitputtende voorbeeld uit 'n preek oor Psalm 98:

"En daarom dan weereens, bierdie indringende, diepsinnige vraag vanoggend: Het $u$ hierdie verlossingservaring? Het u al fesus Christus ontmoet? Het u al die God van Psalm 98, die Koning van Psalm 98, het u Hom al in 'n jubellied raakgesien? Is u deel van sy beerlikheid wat kom? Is u deel van die wederkoms van fesus Christus wat weer op die wolke sal verskyn?...En dit bring my weer eens by die kernvraag: as Jesus vandag op die wolke sal verskyn, as fesus vir u vandag op die wolke sal verskyn, is u gereed om hom in te wag? Lewe daardie lied wat net in Jesus Christus te vinde is en wat van u bele lewe besit kan neem, leef dit in u harte? Is u gereed? Is $u$ gereed om die Bruidegom te ontmoet? Is u gereed om by die bruilofsmaal aan te sit? Sing $u$ 'n lied, die lied van die Koning, die lied van die groot Koning, wat ook vir u uitgehaal en verlos het uit die sonde en die dood?"

By al hierdie vrae kom daar vir die luisteraars nóg 'n vraag by, 'n vraag wat hulle self moet beantwoord: Wat moet ek doen om positief op al hierdie vrae te kan antwoord? Dit stuur die gemeente verbete by die kerkdeur uit, vasbeslote om regmerkies langs elke vraag te gaan plaas; óf moedeloos met die wete dat die voer van meet af aan te hoog vir hulle opgehang is; óf afgestomp omdat hulle weet dat hulle sulke oproepe al soveel keer gehoor en al soveel keer sonder sukses probeer uitvoer het. Uiteindelik laat hulle maar die woorde soos 'n sinlose ritueel oor hulle heen spoel, met die skrale troos dat hulle darem tog één prestasie gelewer het - hulle was in die kerk! Gesien die soort preke wat hulle daar moet aanhoor, inderdaad 'n prestasie! So, onder al die vrae, word mense immuun gemaak teen die evangelie...

Die goeie nuus is: die evangelie vra nie, dit skenk; dit vra slegs in die mate waarin dit skenk.

\subsubsection{Retoriek van die superlatiewe}

'n Tweede metode wat redelik algemeen ingespan word om die hoorders op te skerp om in analogie met die Bybelse gegewens te handel, is die retoriek van die superlatiewe. Die oproep moet benadruk word, die gemeente met behulp van 'n oormaat van byvoeglike naamwoorde en bywoorde tot aksie aangespoor word.

Uit 'n absolute stortvloed van voorbeelde, lig ek 'n enkele uit. In 'n preek oor Joh. 14:25-31 sê die prediker: 
"When the disciples had been Spirit-filled, they knew the truth...But bow do we know that there is a God? And how will that happen? If we are truly followers, truly disciples of Jesus, He has promised that the Spirit, the Helper, will come and reveal the truth about God."

'n Homiletiese ratverwisseling vind plaas tussen when (wat 'n tydsaanduiding is van die indikatiewe werk van die Gees ) en If (wat 'n voorwaardelike konstruksie inlei waarin die gemeente die handelende agent geword het ) Dié ratverwisseling word - heel tipies - geolie met die nadruk truly.

Ek vra weer: Wie kwalifiseer? Wanneer (when) is ek waarlik (truly) 'n dissipel van Jesus?

\subsubsection{Verandering van die tydsvorm}

'n Algemene tendens wat grondliggend is by die meeste van die analises wat tot dusver aan die orde gestel is, maar hier eksplisiet gestel moet word, is die tipies wettiese retoriese tegniek van die verandering van die tydsvorm van die teks. Wat God gedoen het, word wat God sal doen; wat God sal doen, word wat mense (nou) moet doen (vgl. weer 3.7.2).

Een voorbeeld ter bevestiging: ná 'n gedetailleerde en emosionele beskrywing van die toestand waarin melaatses hulle gedurende die tyd van Jesus bevind het - na aanleiding van Lukas 5:12-16 - fokus die prediker op die uitspraak van Jesus in vers 13: "Ek wil. Word gesond." Dié uitspraak vertaal hy as volg:

"Broeders en susters en jong mense, Jesus wil ons reinig van ál ons sonde, Hy wil ons skoonmaak."

Op die oog af lyk dit na 'n herhaling van die "wil" van Jesus in die Bybelteks. Dan kom dit egter:

"Sal u nie vanmôre die voorbeeld van hierdie man van die graf (die melaatse) volg nie? Sal u ook nie na Hom toe kom as Hy ook vanmôre vir u wil sê: "Ek wil. Word gereinig." Ja, kóm in u sonde, kom in u stryd, kom in u swakbeid, maar kom na fesus. Dit is hoofsaak, want soos bierdie man gereinig is, so kan u ook vanmôre vrede met God maak."

Die indikatiewe beweging van die teks, die naatlose verbinding tussen "wil" en "word" word uitmekaargehaal, en 'n vreemde moment daar ingedwing: die vroom beweging van die mens na Jesus toe. Jesus se "wil", wat Hy tot uitvoer bring, word 'n toekomsmoontlikheid - wat Hy slegs tot uitvoer kan bring indien die hoorder na wense handel. Die wig wat tussen 
Jesus se wilsdaad en sy wilsmoontlikheid ingedryf word, word in die preek as 'n driepuntplan vir redding uitgespel, gedra deur die retoriek van die superlatiewe: daar moet eers absolute vertroue, totale nederigheid en innige aanbidding wees voordat Jesus weer kan handel soos in die geval van die melaatse man van die Bybelteks. In die geval van die hoorders red Jesus egter nie (sondermeer) nie; Hy reageer.

\subsubsection{Wanneer die (multidimensionele) teks gemuilband word...}

Uit al bogenoemde analises blyk een van die grondreëls van die prediking: om te bly waak teen die inperking van die belofteryke aard van die Skrif. Maar, wat word presies bedoel met hierdie belofteryke aard van die Bybelteks? Beteken getrouheid daaraan dat daar 'n grammatikale identiteit tussen die Bybelteks en die preekteks gevind moet word? Dit sou sekerlik 'n oorweging moet wees, maar is nie die enigste nie. Om getrou aan die belofteryke karakter van die Bybelteks te bly, beteken, omvattender gesien, dat daar gesoek word na 'n dinamiese ekwivalent tussen tekstruktuur (of beter: tekskultuur, dit wil sê die dinamiese beweging van die teks, dit wat die teks wil; vgl. 4.6.4) en preekstruktuur. Hierdie dinamiese ekwivalent sluit meer in as bloot die bepaling van 'n tydlose teologie wat ook los van die spesifieke struktuur van 'n spesifieke Bybelteks sou kon bestaan. Dit mik ook op meer as byvoorbeeld die uitklaring van 'n vasstaande "beloftevervulling" skema. Eerder word gevra na die spesifieke lyne en kontoere van die oorspronklike predikingsgebeure soos dit in die Bybelteks tot uitdrukking kom. Die spesifieke aanslag en doelwit van elke Bybelteks, die bepaalde verkondigingstruktuur daarvan, of dit nou in die vorm van 'n elenktiese wet, 'n indikatiewe vryspraak of 'n paranetiese gebod is, bied die ruimte waarbinne die belofte van God se handelinge nagespoor kan word, ten einde tot 'n aktuele verkondigingstruktuur vir die preek te kom (vgl. Müller 1973:128). Om die belofteryke karakter van die Bybelteks tot sy reg te laat kom, vra meer as 'n vasstelling van wat daarin gesê is, ook meer as 'n namaaksel van boe dit gesê is, maar dring ook deur na die vraag waarom dit juis so in die Bybelteks gesê word. Die teksnegerende effek van wettisisme is nie alleen om die inhoud van wat God gesê het, of die wyse waarop Hy dit sê, van die tafel te vee nie, maar ook God se bedoeling daarmee. Wettisisme is in feite ' $n$ ontkenning van hierdie bedoeling van God met mense, 'n verklaring dat daar by hulle nie 'n behoefte of noodsaak hieraan is nie. Dit bring die belofteryke spreke van God tot swye, laat die vele gestaltes daarvan verstom. Wettisisme is - dis één moment daarvan - 'n gevolg van die uitskakeling van die Skrif, maar tegelykertyd 'n proses wat hierdie uitskakeling aktief bewerkstellig, wat onder meer daartoe lei dat die Bybelteks met sy veelkleurige en belofteryke spraakgestaltes verstom, dat 
dit gemuilband word. Dit kan byvoorbeeld op die volgende maniere gebeur:

\title{
4.7.4.1 Die wettiese vervalsing van die indikatief van die evangelie
}

Hierdie vorm van wettisisme is dikwels die moeilikste om te ontmasker. Op die klank af klink sulke preke evangelies, veral ook waar dit begelei word met 'n oorvloed van Christologiese formules. Die vraag is egter of die blote aanhaal van sulke formules noodwendig saamgaan met die ontginning van die evangeliese kwaliteit daarvan (vgl. 3.7). Dikwels word die wettisisme juis verberg in 'n opeenstapeling van Reformatoriese sola's, of vermom in 'n gewaad van Christologiese korrektheid. Dit alles vorm egter slegs 'n voorwoord tot die eintlike woord, naamlik die verkondiging van moraliserende appèlle.

'n Interessante voorbeeld hiervan is 'n preek oor Handelinge 10, met die tema: "Divine Appointment". Die prediker begin met 'n vertelling van sy eie ontmoeting met Jesus: "I had a divine appointment with the Lord Fesus Christ." Dan wend hy sy blik tot die hoorder: "God wants a divine appointment with you..." Wie bestel hierdie afspraak? Wie voer dit uit? Dit wil voorkom asof die prediker hierdie vraag Christologies-evangelies wil oplos, as hy redelik uitgebreid begin praat oor Christus as die "anointed One", "compassionate One", "suffering One", "the risen One”, "ordained and exulted One" en "the Saviour for all mankind" - alles predikate wat in Handelinge 10 teruggevind kan word. Hierdie betitelings, wat die werklikheid van Jesus se heilswerk uitdruk, word egter almal hulle krag ontneem wanneer die preek oorloop in 'n beskrywing van die moontlikheid dat Jesus sal handel - indien die hoorders daartoe instem. Die "divine appointment" word uit die kragveld van die genadige werk van God uitgehaal, en afhanklik gemaak van die raadsplanne van mense. Ons hoor:

\begin{abstract}
"In the heart of the Lord Jesus Christ He wants to bless you this morning...He wants to beal you this morning...He wants to bless us, He wants to beal us, He wants to deliver us. He is able this morning to touch us. He is able this morning to love us...Allow Him to love you. Allow Him to free you. Allow Him to beal you. Allow Him to encourage you. Allow Him to deliver you."
\end{abstract}

Blykbaar is Christus baie gewillig en geheel en al daartoe in staat, maar voer Hy tog nie die "divine appointment" uit nie. Hy moet wag totdat die hoorders die afspraak nakom, voordat $\mathrm{Hy}$ iets kan doen. Die "divine appointment" is toe nie so "divine" nie... 


\subsubsection{Die wettiese vervalsing van die imperatief van die evangelie}

Dit vind waarskynlik die maklikste plaas. Teksverse wat gebied, kan makliker as teksverse met' $n$ indikatiewe struktuur misverstaan word, makliker gesien en gepreek word as naakte bevele en eise wat God aan mense rig. Daarom is dit so belangrik om juis hier die evangeliese raamwerk waarbinne dit staan, goed in die oog te hou. Die Bybelse gebod is nooit bloot 'n naakte bevel nie, maar eerder die kragtige toesegging, die belofteryke uitnodiging om jou geloof elke dag uit die werklikheid van die verlossing te lééf. Wat ek vroeër oor wettiese vraagstellings gesê het (4.10.1), kan hier op 'n ander wyse bevestig word: God gebied in die mate waarin Hy skenk; Hy skenk ook in die mate waarin Hy gebied. Die gebod is by uitstek tuis in die huis van die evangelie.

Nie so in die volgende preek wat onder meer 'n uitleg gee van 1 Tessalonisense 5:18 nie. Die preek begin, soos dit dikwels die geval is, met sinne wat reeds die wettiese uiteinde van die preek bevat en voorberei:

"Na vanaand se diens sal Pinkster 1995 iets van die verlede wees. Pinkster word gehou elke jaar, nie omdat dit' $n$ wet is waarom ons Pinkster moet hou nie (sic.)...En eintlik behoort ons nie net Pinkster een week te bou in die jaar nie; ons behoort 52 weke in 'n jaar behoort ons Pinkster te bou. Dit is die maatstaf wat God wil hê waarvolgens ons moet leef. Pinkster is nie net vir een dag of een week bedoel nie, maar dit moet voortdurend daar wees".

Ironies genoeg verklaar die prediker eers dat Pinkster nie bedoel is as 'n wet nie (dalk'n onbewustelike aanvoeling dat sy hermeneutiek hom inderdaad juis hiertoe verlei?), maar dan volg die tipies wettiese spraak in 'n dik stroom: behoort...maatstaf...moet, en natuurlik, dat God dit so wil hê. Wanneer hy sê: "dit moet voortdurend daar wees", sê hy nie wie dit voortdurend daar moet láát wees nie. Die sin bly sonder 'n handelende subjek. Van wie hang die heilsfeit van Pinkster nou af? God? Die mens? Dat laasgenoemde in werklikheid bedoel word, en dit op 'n wettiese wyse, word duidelik uit die uitleg van 1 Tessalonisense 5:18:

"U sê vanaand vir my: Wat is my posisie as ek nie gevul is met die Heilige Gees nie? Ek wil vir u sê u leef in gruwelike sonde. U sê: "Hoe kry ek dit reg?" Ek kry dit reg, want die Woord van God sê vir ons - 1 Tessalonisense 5:18 - "Word vervul met die Heilige Gees."...Hierdie is nie 'n belofte om te eis nie; dis 'n bevel om te gehoorsaam. En ek wil vanaand sê: Broer, suster, hoorder - luister mooi - God verwag dat elke mens met wie hierdie woord spreek, diep in sy hart, wat die Woord van God hoor - "Word vervul 
met die Heilige Gees" - die Here verwag dat u vervul moet word met die Heilige Gees...Ek vra u vanaand: Is u en ek gereed vir die Evangelie? Ek vra u vanaand. As u nie 'n kind van God is nie, vra ek ook vir u bierdie vraag: Is u gereed om die Evangelie te bring?"

Indien 'n mens 1 Tessalonisense 5:18 as 'n naakte bevel verstaan, kan jy seker sê God verwag van jou om vervul te word met die Heilige Gees. Maar is dit die evangelie? Die hoorder word van alle kante met eise gedruk: Pinkster "moet voortdurend daar wees", en God "verwag" dit ook nog. Is die teksvers inderdaad 'n bevel om te gehoorsaam, of 'n belofte om te eis? Is word vervul nie 'n passiewe werkwoordsvorm ("laat God julle vervul"), wat teologies alleen te verstaan is binne die raamwerk van God se aktiewe werk deur sy Gees nie? God verwag niks van ons nie. As dít die geval sou wees, was die evangelie nie nodig nie, of hoogstens 'n hulpmiddel om ons te help om ons eie potensiaal te verwesenlik.

\subsection{5 'N ANDER WEG?}

Ek keer terug na my stelling dat wettisisme in die prediking dikwels gebore word uit die "probleem" wat deur die aard van die Skrif veroorsaak word, naamlik dat dit 'n historiese boek is wat teologiese uitsprake maak. Dit bring mee dat die brug tussen wat God in die verlede gedoen het en wat Hy nou doen, op wyses geslaan word wat meestal wetties op die hoorder inwerk. Die vraag is nou: Op watter wyse moet dit dan gebeur? Is daar'n weg of weë wat die unieke aard van die Skrif só honoreer dat die werklike mens vir wie gepreek word die evangeliese bedoeling daarvan hoor? Hierdie is 'n komplekse vraag, 'n worsteling waarmee alle predikers bekend is.

In aansluiting by wat reeds in 4.6 .4 gesê is, wys ek op die volgende basiese perspektiewe, wat na my mening van deurslaggewende belang is veral in die lig van die verskynsel van wettisisme in die prediking. Josuttis wys al daarop dat daar net een verantwoorde wyse is waarop die hermeneutiese oorgang bewerkstellig kan word, en dit is met behulp van die leer, en dan spesifiek die Godsleer, as die mees innerlike senuwee van die teologie (1966:27). Enige ander metode (antropologies, retories, ens.) berg in homself die kiem van die wettisisme. Met die Godsleer word egter nie 'n tydlose stel van dogmatiese waarhede bedoel nie, maar eerder 'n Godsgebeure, wat die belofte inhou van God se teenwoordigheid (vgl. weer hoofstuk 3). In die prediking gaan dit, soos reeds gesê, om die spesifieke handeling van God soos geopenbaar in die oorspronklike verkondigingstruktuur van die Bybelteks. Die dinamiese ekwivalent tussen die teksstruktuur en die preekstruktuur beteken egter nie 'n blote resitasie van wat God in die verlede gedoen het nie, maar sluit die waagstuk in om, in die lig van die 
Bybelteks, die handelinge van God nuut uit te spreek in die hede, of beter gestel, die nuwe handelinge van dieselfde God in die hede uit te spreek. Alleen so word die oorpronklike verkondigingstruktuur 'n aktuele verkondigingstruktuur waarin die groot dade van God aan die mens van die hede bekendgemaak word. Die belofteryke aard van die Bybelteks sluit juis dit in, nooi juis uit om dit te ontdek. Om eksegeties korrek te preek, is belangrik, maar is nie die finale doelwit van die prediking nie, trouens, korrek kan hier soms verkeerd wees. Die wonder van die prediking is dat dit werk met tekste waardeur die lewende Persoon van God tot ons kom, tekste met 'n teologiese aard in die sin dat dit primêr die stories van die handelende God vertel en verder vertel (Niebuhr 1941:32-66;101-113). Streng genome verkondig ons egter, soos voorheen reeds aangedui, nie tekste as 'n doel in sigself nie, maar die lewende Persoon van God, is die teks hoogstens die bril waardeur ons 'n nuwe visie op hierdie God en die werklikheid verkry. Mense hoef die teks nie op 'n (wettiese) wyse waar te maak nie; God maak dit waar. Mense hoef nie volgens allerlei moralistiese metodes te word of te wees soos die figure in die Bybelteks nie, hoef nie die historiese situasie van die teks te reproduseer om die aktualiteit daarvan te ervaar nie. Die afstand tussen die teks en ons word deur God self oorbrug. Dit is die Alfa en die Omega van die prediking, wat nie die handelinge of reaksie van mense uitsluit nie, maar juis (teologies) insluit. Dáárom is die prediking allereers vreugde, 'n vreugde wat saamhang met die ontdekking van die belofte van die teks, wat lei tot 'n nuwe visie van God in die hede, 'n nuwe droom wat van Hom in die huidige werklikheid gedroom kan word, 'n droom waarin die gemeente hand aan hand met die lewende God die werklikheid nuut kan lees, nuut kan verstaan en opnuut kan verander. Die bedoeling van die prediking is nie om 'n arsenaal van resepte aan mense te gee waarvolgens húlle die werklikheid moet verander nie; eerder om hulle oë te open sodat hulle die werklikheid van God se werksaamheid in die wêreld kan onderskei, en om hulle uit te nooi om daaraan mee te doen. Die waagstuk en die wonder van die prediking lê daarin dat die belofte van die Bybelteks só ontsluit word dat die gemeente God in sy handelende teenwoordigheid in hulle spesifieke konteks sal ontdek, en in die vreugde daarvan ingevoer sal word.

In sy boeiende Predigtlehre verhef Rudolf Bohren juis die vreugde tot een van die hoekstene van sy homiletiek (1974:17 e.v.). Hy beweeg weg van die tradisionele "uitleg-toepassing" (explicatio-applicatio) skema wat maklik tot 'n valse objektiwiteit én 'n valse subjektiwiteit kan lei, waarin die Bybelteks enersyds as 'n afgeslote sisteem funksioneer, 'n versameling van historiese voorbeelde van eksistensmoontlikhede, en die gemeente andersyds as ' $n$ versameling van mense met die potensiaal om hulleself aan hierdie moontlikhede te meet en hulleself daaraan te konformeer. Bohren 
praat eerder van die verskillende tydsvorme van die Woord, waarmee hy nie bloot die grammatikale tydsvorme van die Skrif op die oog het nie, maar eerder die verskillende wyses waarop die één God Homself in verskillende tye verwoord en dus as handelende God openbaar (1974:142 e.v.). Die skakel tussen verlede, hede en toekoms lê in die Naam van God, wat egter nie as 'n cliché bedoel word nie, maar as die mees basiese hermeneutiese beginsel vir alle prediking, ja vir die teologie in die algemeen. Wie bloot met die Bybelteks werk as 'n instrument vir explicatio en applicatio gaan inderdaad by beide die teks én die gemeente verby, want dis alleen in die hermeneuties-verantwoorde verkondiging van die Naam van God dat die evangelie tot sy reg kom, dit wil sê dat die belofte van die teks aan die gemeente vir wie dit bedoel is, ontsluit word.

In die volgende hoofstuk let ons juis op die betekenis van die gemeente as die derde noodsaaklike element van die preekmaakproses. 


\section{Preekvoorbeeld 2 \\ NEEM, LEES! \\ (Jesaja 55:1,6-13)}

\section{So sal die woord wat uit my mond kom, ook wees... (Jes. 55:11)}

Die groot kerkvader Augustinus vertel in sy boek Confessiones van dié dag toe hy tot bekering gekom het - as gevolg van die kragtige werking van God se Woord. Hy was 'n uiters begaafde man, maar het tot in daardie stadium 'n redelike roekelose lewe as 'n filosofiestudent in Rome gelei, hoewel hy 'n knaende onrustigheid diep binne-in hom ervaar het. Aan die een kant wou hy tot bekering kom, maar aan die ander kant ook nie. Hy het selfs kwasi-vroom gebid dat die Here hom tog moet verander - maar, het hy gewoonlik bygevoeg, asseblief tog net nie nou al nie! Dié spanning in sy lewe het opgelaai. Op 'n dag het dit hom uit die huis uit gedryf, en moes hy buite in sy tuin gaan stap om oor sy lewe na te dink. Hy beskryf wat met hom gebeur het, as volg:

"Ek het myself onder 'n vyeboom neergegooi en my trane vrylik laat vloei. Ek het jammerlik na bo geroep: Hoe lank, hoe lank? Môre, en môre? Hoekom nie nou nie? Hoekom kom daar nie in hierdie uur 'n einde aan my onreinheid nie?

"Ek was besig om hierdie dinge te sê en het gehuil in gebrokenheid van hart, en skielik het ek die stem van 'n seun of 'n dogter gehoor - ek weet nie watter een nie - wat van 'n naburige huis gekom het, en singend 'n paar keer herhaal het: Tolle, lege! Tolle, lege!

"(Neem, lees! Neem, lees!) Ek het onmiddellik opgehou om te huil, en ek het gewonder of dit dalk moontlik sou kon wees dat kinders sulke woorde in enige soort speletjie sou gebruik, want ek kon nie onthou dat ek so iets al ooit tevore gehoor het nie. Ek het opgestaan, want ek kon aan niks anders dink nie as dat hierdie 'n goddelike opdrag aan my was om die Bybel oop te makk en die eerste gedeelte te lees waarop my oë sou val nie.

"Ek het vinnig teruggekeer na die bank waar Alypius gesit het, want dis waar ek die apostel Paulus se brief aan die Romeine laat lê het. Ek het dit opgeraap, oopgemaak, en in stilte die gedeelte gelees waarop my oë eerste geval het - Fulle moet lewe soos volgelinge van die Here fesus Christus en nie voortdurend daarop uit wees om julle sondige begeertes te bevredig nie (Rom. 13:14).

"Ek wou niks verder lees nie, dit was ook nie nodig nie, want onmiddel- 
lik, soos wat die sin geëindig het, het daar iets soos die lig van volle sekerheid in my hart ingeskyn, en al die duisternis van twyfel het verdwyn." In daardie oomblikke het die Woord Augustinus aangegryp soos nog nooit voorheen nie, en het sy lewe radikaal verander. Was dit vir hom asof die Here persoonlik en direk voor hom kom staan en deur dié Bybelteks met hom gepraat het. Asof die vergeelde bladsye van 'n stuk Bybelperkament 'n poort geword het waardeur die Here van hemel en aarde self na hom toe aangestap gekom het...

Miskien het ons nog nie só 'n dramatiese ervaring met die Bybel gehad nie. Maar dit gebeur tog soms met ons dat ons die Woord lees en lees, en dit vir ons voel asof niks daarin vir ons bedoel is nie. Dat dit oënskynlik niks aan jou doen nie, jou nie koud of warm mak nie. Totdat iets in die Bybel jou op 'n dag aangryp soos nooit voorheen nie, 'n woord, 'n frase, 'n waarheid as 't ware uit die Bybel na jou toe spring en jy net weet: nou praat die Here van hemel en aarde self met my.

Só 'n woord moes Jesaja 55 vir Israel gewees het. Hulle bevind hulle in ballingskap - sekerlik die ergste wat met 'n Israeliet kón gebeur. Weggevoer van hulle grond, goed, tempel, en oënskynlik ook hulle God. Ja, oënskynlik het ook die woord van die Here in Jerusalem agtergebly. Sy beloftes het blykbaar nie in vervulling gegaan nie. Hier in Babel is die Here op die oog af nie te vinde nie, het sy woord verstom. Sommige het begin wanhoop, het selfs die rug op die Here gedraai, Jerusalem begin vergeet, ingeburger begin raak in Babel. Kortom, Israel bevind hom in 'n woestynervaring, soos die bokkie van Psalm 42 wat smag na 'n druppeltjie water, maar oënskynlik is selfs dít nêrens te vinde nie.

Dalk ken jy dié gevoel...

Ter wille van sulke mense, mense wat wanhoop aan die krag van God se woord, staan Jesaja 55 onder meer in die Bybel. Die hoofstuk val sommer al in die eerste vers met die deur in die huis, of eerder: trek sommer dadelik die sluise oop vir dorstiges, is soos 'n fontein wat oopbreek vir woestyngangers, wanneer die Here self daarin sê:
Kom, almal wat dors is,
kom na die water toe,
selfs ook dié wat nie geld bet nie, kom,
koop en eet;
ja, kom, koop sonder geld
en sonder om te betaal,
wyn en melk. (1)

Só ruim is hierdie uitnodiging dat sommige van die ortodokses in Israel begin murmureer het. Wat? Kan almal dan maar kom? Selfs ook die 
ontroues en drosters? Ook dié wat in Babel die rug op die Here gedraai het? Is die genade dan nie net bedoel vir die getroues en die toegewydes nie? Nee, dis bedoel vir almal. Ja, álmal.

Die antwoord wat die Here op hierdie murmureringe gee, tel sekerlik nie alleen onder van die bekendste uitsprake in die Bybel nie, maar is ook van die vreemdste, maar wonderlikste woorde:

My gedagtes is nie julle gedagtes nie,
en julle optrede nie soos Myne nie,
sê die Here:
soos die bemel boër is as die aarde,
so is my optrede
verbewe bo julle optrede
en my gedagtes bo julle gedagtes $(8,9)$.

Hiermee word nie alleen gesê dat die Here, vanuit ons menslike gesigspunt, soms raaiselagtig optree nie, maar veral dat sy genade, sy bereidheid tot vergifnis, telkens ons kleingeestigheid, ons bekrompe Fariseërsingesteldheid verreweg oortref. Ja, die Here vergewe altyd weer (7). Die aanbod van sy genade is ruim en wyd. Hierin lê ons troos: die woord van die Here wat tot ons kom, is by uitstek 'n genadewoord, 'n vryspraak, 'n vergifnis. Dit sê: Die Here ís naby, Hy ís te vinde (vgl. vers 6), ook in Babel, ook in die woestyn, en ook op jou moedverloor se vlakte.

Maar die troos gaan nog dieper. God se genadewoord is nie bloot 'n veraf, teoretiese woord oor vergifnis en genade nie, nie 'n woord wat, nadat dit uitgespreek is, êrens onseker in die lug rond huiwer nie, maar 'n daadkragtige, werksame woord. Want:

Die reёn en die sneeu

kom uit die bemel uit

en dit gaan nie daarbeen terug nie

maar deurweek die aarde

en laat die plante bot en vrugte dra,

sodat daar saad is om te saai

en brood om te eet.

So sal die woord wat uit my mond kom,

ook wees:

dit sal nie onverrigter sake

na My toe terugkeer nie,

maar dit sal doen wat Ek gedoen wil hê

en tot stand bring

waarvoor Ek dit gestuur bet $(10,11)$. 
$\mathrm{O}$, ons mag soms dínk dat God se woord stom is, dat dit nie werksaam is nie. Ons mag reken dat die Here maar moed opgegee het met ons. Die tyd waarin die Woord soos die water van die reën en sneeu in die grond in wegsink, mag soms vir ons lank voel, mag ons inderdaad in 'n woestynervaring dompel. Nou mag die werking van die Woord nog vir ons verborge wees - maar dit werk! Die seën daarvan val soos die reën op ons, deurdrenk ons, al sou ons dit dikwels nie eers agterkom nie! Ja, selfs al sou ons ons daarteen verset - dié Woord keer nié leeg terug na die Afsender daarvan nie!

Maar... kán 'n mens jou dan teen die Woord verset? Ja, hoe tragies dit ookal mag wees, die onmoontlike kán blykbaar moontlik word: jy kán in jou skuilplekkie teen die reën van die Woord probeer wegkruip. Jy kán probeer om jou sambreeltjie teen die druppels van genade oop te maak. In plaas daarvan dat jy in die reën gaan staan om skoon gewas te word! Dat die sneeu op jou val dat dit jou witter kan was as sneeu! Dat jy van die water van die opborrelende fontein drink! Dat jy vra na die wil van die Here terwyl Hy nog te vinde is, Hom aanroep terwyl Hy nog naby is! (6) Ja, dit mag nog voel asof die Woord in die grond in weggesyfer het, asof dit kragteloos is, maar dit sal gewis vrug dra, sal ons beslis uit ons ballingskappe red. Uiteindelik sál die lewegewende water van die Woord só diep in ons woestynervaring indring, dat dit die vrug van 'n uittog oplewer, en ons lewens in 'n lushof omskep.

So was dit histories gesproke vir Israel met hulle terugkeer na Jerusalem, en so sal dit vir ons wees wanneer God se onweerstaanbare Woord ons finaal uit die ballingskap van hierdie bedeling sal lei, en ons saam met die ganse skepping bevry sal word van die verslawing aan die verganklikheid, om so tot die vryheid te kom wat hoort by die heerlikheid van die kinders van God (Rom. 8:21). Ja, só groots sal hierdie uittog wees, dat selfs die skepping dit moet toejuig, ook die berge en heuwels voor ons uit sal moet jubel en juig en al die bome in die veld sal moet hande klap (12). Die Woord werk 'n nuwe hemel en aarde uit, waar daar in die plek van 'n doringbos en 'n dissel (beelde van die sondeval) 'n mirteboom en 'n sipres (beelde van die paradys) sal opskiet. Dit sal tot eer van die Here wees, 'n blywende teken wat nooit vernietig sal word nie (13).

Behoort ons dít nie nog beter te weet as selfs die profeet Jesaja nie? Immers, God se werksame Woord van genade, sy weldeurdagte Woord van vergifnis, het mens geword en onder ons kom woon (Joh. 1:14). Hierdie Woord bereik by uitstek alles waartoe God Hom gestuur het, keer nie onverrigter sake na die Vader toe terug nie. $\mathrm{O}$, op die oog af mag dit ook lyk asof selfs $H y$ nie veel uitwerking in hierdie wêreld het nie, en maar in die grond in wegsyfer. Trouens, Hy het soos 'n koringkorrel in die grond geval en gesterf, maar sodat Hy 'n groot oes kon inbring (Joh. 12:24). Die Woord, 
die mensgeworde Woord, breek bo die grond uit, breek deur die wande van die graf, en wie kan Hóm keer?

Ons leef in ' $n$ besonderse tyd, staan aan die begin van 'n nuwe millenium. Ook - veral! - nou ís God naby, ook nou ís sy wil te vinde. Ook nou is dit die regte tyd, ook nou is dit die dag van redding (2 Kor. 6:2). Ons het die Boek van alle boeke wat dít vir ons sê, op elke bladsy, van begin tot einde. O, laat dié Woord tog nie soos druppels op ons neerreën, en ons voel dit nie, hóór dit nie. Laat dit nie in ons wegsink, en ons dra geen vrug nie! Mag ons eerder met die Bybel omgaan soos Christoph Blumhardt skryf:

"Dikwels, wanneer 'n mens 'n Bybelwoord lees, is dit soos 'n woord wat glad nie deur mense geskrywe is nie, soos 'n woord wat hom losmaak van alle menslike rede, en is dit omsluit in 'n wolk van goddelike krag, van goddelike handeling. Dan gaan dit in ons harte in, en begryp ons glad nie dat so iets moontlik sou kon wees nie. Ons het dit geensins verstaan nie, of het geglo dat dit hoegenaamd nie vir ons die moeite werd sou wees om die Woord nog te lees nie, want dis so bekend aan ons, alreeds vanaf ons skooldae. En skielik kom so 'n woord tot ons, soos 'n sterker, magtiger engel, wat met 'n heilige hand ons harte aanroer, en ons liggaam en siel word geopen, en ons asem iets in van 'n hemelse Woord, van dié Woord wat wonders doen, wonders aan ons hart, wonders in ons gevoel, in ons denke, wonders in alles wat ons is."

Wat kan 'n mens meer sê?

Neem, lees! Neem, lees! 


\section{HoOfstuk 5}

\section{Die lewende stem van die evangelie: wanneer die gemeente praat}

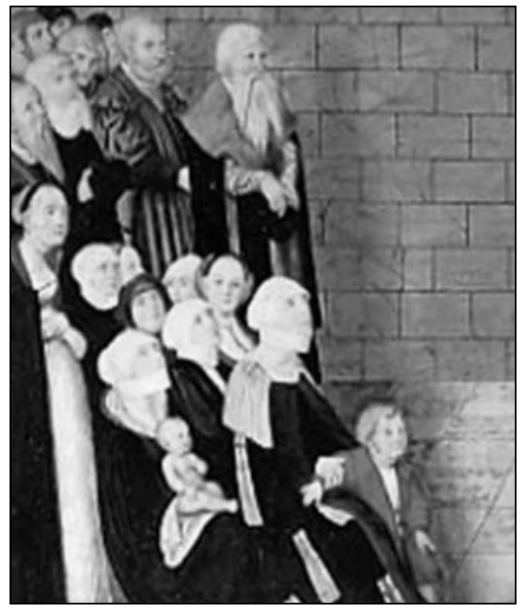

Dit is van deurslaggewende belang vir die prediking dat ons 'n gesonde teologiese visie op die gemeente sal hê. In hierdie hoofstuk let ons op

- Die konstituerende rol van die gemeente in die preekmaakproses self

- Die invloed van, en reaksie op, die konteks waarbinne die gemeente haarself bevind

- Preekvoorbeelde van 'n mislukte (moralistiese) visie op die gemeente

\subsection{Inleiding: in-stemming met die gemeente}

"Die Woord van God kan nooit losgemaak word van die volk van God nie." Met hierdie skerpsinnige formulering vra Luther opnuut ons aandag vir 'n prinsipiële 
verhouding, wat ook vir die homiletiek van deurslaggewende belang is (vgl. Meuser 1983:112). Dit benadruk die feit dat dit in die prediking van die Woord van God handel om die volk van God, om die gemeente wat versamel is om die Woord te hoor. Luther se opmerking impliseer selfs dat die wyse waarop die Woord van God na die gemeente toe kom, wesenlik deur die realiteit van die gemeente beïnvloed word. Hierdie (homiletiese) verhouding, hierdie wisselwerking tussen teks en gemeente word raak deur Tom Long beskryf:

We go to scripture, then, not to glean a set of facts about God or the faith that can be announced whenever and wherever, but to encounter a Presence, to hear God's voice speaking to us ever anew, calling us in the midst of the situations in which we find ourselves to be God's faithful people. The picture of the preacher sitting alone in the study, working with a biblical text in preparation for the sermon, is misleading. It is not the preacher who goes to the scripture; it is the church that goes to the scripture by means of the preacher. The preacher is a member of the community, set apart by them and sent to the scripture to search, to study, and to listen obediently on their behalf. So the preacher goes to the scripture, but not alone... The preacher explores the scripture, faithfully expecting to discover the truth of God's claim there and always willing to be surprised by it. Those who have sent the preacher have questions and concerns, and sometimes the text will speak directly to those questions. The text may, however, call those questions into question. (1989: 45)

Die teks behoort dus nie aan die prediker nie. Net so min as wat 'n aartsindividualis, wat nie "ons" kan spel nie, die reg het om 'n plek op die kansel vol te staan. Die Bybelse teks behoort aan die gemeente, en moet as 't ware van lidmaat na lidmaat aangegee word om van alle kante bekyk en beluister te word, totdat almal saam kan stem, en sê: ons het God se stem gehoor. Om te preek is nié om 'n teologiese diktator, of 'n gevleuelde orator, of 'n heilige askeet te wees wat buitekant of bokant die gemeente wil leef nie; dis eerder om in-stemming met die gemeente rondom 'n Bybelteks te vind. Want: "Die Woord van God kan nooit losgemaak word van die volk van God nie."

\subsection{Die gemeente: draer en beskermer van die waarheid}

Die geheim van die prediking het te make met die stem van die teenwoordige God en die stem van die Bybelteks. Daar hou dit egter nie op nie. Die spiritualiteit van 'n prediker blyk nie net uit sy of haar verhouding tot God of uit die omgang met die Bybelteks nie, maar ook uit die verhouding tot die gemeente, uit die wyse waarop die prediker na die stem van die ge- 
meente luister. Die klassieke vergelyking moet dus ook hier uitgebrei word: lex orandi, lex credendi, lex vivendi, lex convivendi, lex praedicandi (soos jy bid, so bely jy, so leef jy, so leef jy saam, so preek jy). Oor hierdie convivendi, in hierdie geval, die saamleef met, en luister na die gemeente en die implikasies daarvan vir die prediking, handel dit in hierdie hoofstuk.

Die stem van die gemeente móét eenvoudig in die preekmaakproses gehoor word. Die prediking is immers gerig op die gemeente, maar dit kom ook op uit die gemeente. In 'n sin ís die prediking die gemeente se "eiendom", en nie die prediker se privaatbesit nie (Bluck 1989: 33). Wie die Bybelse tekste bloot as individue wil lees, loop gevaar om eenogig te wees. Die teks is eenvoudig té diep, té ryk, té multidimensioneel om slegs deur één na regte gelees te word. Daar is meer as een waarheid, meer as een gesig van God in elke teks, meer as wat een oog kan bevat. Daarom het die prediker die baie oë van die gemeente nodig, moet sy of haar uitleggers - en verkondigingsvoorregte verruim word om die gemeente in te sluit.

Maar, lei die klem op die veelheid van waarhede en insigte nie tot relativisme nie? As daar baie waarhede is, beteken dit dat daar nie één waarheid is nie? Nee, nie noodwendig nie. Elke teks moet in sy veelkleurigheid teen die fundamentele teks van die Skrif gelees word, vind sy samehang in hierdie fundamentele teks. Die vraag is natuurlik: wie bepaal wat hierdie fundamentele teks is?

Op 'n eerste vlak sou ons moes sê: nie net individuele uitleggers soos predikante en teoloë nie. Die Bybel is die Boek van die kerk, in die breedste $\sin$ van die word. Dis hier waar die bermeneutiek van ekumenisiteit sy funksie het: my siening van die fundamentele teks, en elke ander teks, moet ek saam met, en deur die pyn van ander lees, altyd met twee grondreëls in gedagte: eerstens, dat my perspektief niemand anders mag skade aandoen nie, en tweedens, dat ek self oop moet wees om te kan luister na die perspektief van ander, en gewillig moet wees om te verander. In dié sin kan die lees van die Bybelteks, en trouens van die hele preekmaakproses nie as 'n uitsluitlik individualistiese handeling of teologiese privaatbesit van die predikant beskou word nie.

'n Ekumeniese hermeneutiek funksioneer daarby ook nie net in wydte nie, maar ook in diepte: dit het 'n oog vir die werking van dié spesifieke teks in die kerkgeskiedenis; dit luister na die eggo's van hierdie teks se werkingsgeskiedenis in die geskrifte en getuienisse van die kerkvaders en kerkmoeders. 'n Ekumeniese hermeneutiek kan nooit vaderloos en moederloos wees nie, en daarom ook nie weeskinder-preke baar nie. Dit staan in 'n ryke tradisie wat ons van teologiese arrogansie bewaar, en ons telkens herinner aan die troos en aansporing van die groot skare van geloofsgetuies wat rondom ons is (vgl. Heb 12:1). Wie ekumeniese hermeneutiek wil beoefen, word nederig. Luther het blykbaar op 'n papiertjie kort voor sy 
dood geskryf: Niemand kan die Skrif verstaan as by nie 'n honderd jaar saam met die apostels en profete die kerk regeer het nie...

Die gemeente is die draer en beskermer van die waarbeid (1 Tim 3:15). Die "amen" van die dominee beteken daarom nie die einde van die preek nie maar in 'n sekere sin die begin daarvan, aangesien die gemeente nog húl "amen" daarop moet sê, húl reg en mag as ontvangers van die Woord moet uitoefen... (vgl. ook 5.3.2)

Die prediking begin en eindig inderdaad nie met die preekmoment nie; die gemeente gaan die prediking vooraf en volg dit op met 'n Amen! Maar hierdie amen is nie die einde van die preek nie, eerder 'n nuwe begin - só, dat die gemeente sélf nou predikers word in 'n wêreld wat wag om die evangelie te hoor. Die preekmaakproses moet daarom van begin tot einde, van die voorbereiding tot die aanbieding tot die nawerking van die preek, deur die gemeente prinsipieel mede-bepaal word. Predikers moet die rykdom, die homiletiese potensiaal wat daar in die gemeente steek, raaksien en benut. Trouens, van die beste kommentaar op die prediking vind predikers nie net op hulle boekrakke nie, maar ook in die murg en bloed, in die weefsel, ja in die konteks van die gemeente wat rondom die prediking lééf.

Dit vra dat predikers met nuwe oë na hulle gemeentes sal kyk, dat hulle 'n teologiese sleutel sal hanteer as hulle die geheime van die gemeente wil ontsluit. Dat hulle diégene wat in die erediens kom, teologies sal beoordeel, dit wil sê as mense met wie God lank reeds werksaam is, mense vir wie Christus gesterf het en opgewek is, mense vir wie God se genade daarom genoegsaam is. Dat hulle diégene wat in die kerkbanke sit, as gawes van God sal sien, eerder as godsdienstige kliënte wie se belange so goed moontlik gehanteer moet word. Maar, wat beteken dit alles vir die preekmaakproses? Die opmerkings van Karl Barth in dié verband spreek van wysheid. Hy groepeer dit in vyf gedagtegange - verkort hier weergegee:

- Die prediker moet sy of haar gemeente liefhê, en een met hulle wees. Die grondhouding moet een wees van: hierdie is my mense en ek wil met hulle deel wat God aan my gegee het. Al is jy ook hóé welsprekend, al praat jy beter as engele, sonder liefde baat dit niks...

- Omdat die prediker die gemeente liefhet, moet hy of sy die lewe van die gemeente leef, op hulle vlak. Die prediker hoef nie noodwendig die slimste persoon onder die mense te wees, of die dorpswaarseêr wat die mees verborge gedagtes van mense kan blootlê nie, maar die vraag wat hulle diepste gedagtes werklik is, moet altyd op die prediker se hart druk.

- Die prediking is nie bloot ' $n$ helderder en meer adekwate verduideliking van wat die betekenis van die lewe is, te midde van ander verduidelikings nie - hoewel dit nie onbelangrik is nie - maar eerder 'n plasing van die betekenis van die lewe binne die lig van God se openbaring. 
- Om te preek, is om taktvol te wees! Is om te weet wat om wanneer vir wie te sê. Wanneer daar wel Bybelse en profetiese kritiek uitgespreek moet word, mag dit alleen in 'n nederige en gewyde gees geskied - dit is nie nodig om 'n afgod van die waarheid te maak nie.

- Om te preek, is om bewus te wees van die oomblik, van die uur waarin beide prediker en gemeente verkeer. Dis om te vra: watter eise stel die kontemporêre situasie aan die prediker en gemeente? Immers, beide prediker en gemeente deel dieselfde historiese ervaring; daarom moet die woorde van die prediker relevant wees vir die onmiddellike belange van die hoorders. As dít verstaan word, sal predikers beter op hulle hoede kan wees teen 'n onophoudelike diskoers oor temas wat lankal hulle relevansie verloor het (1964:96-97).

Dit onderstreep die feit: predikers moet by hulle gemeentes wéés, nie op 'n ander (teologiese, sosiologiese, kosmologiese) planeet nie. Dit sal waarskynlik aanpassings in die preekmaakprogram van die prediker vra, asook die skep van geleenthede en strukture waarbinne die insette van die gemeente op die beste wyse tot hulle reg kan kom. Dit vra dat die prediker sy of haar gemeente meer dikwels rondom die preekteks in die oë sal kyk, en hulle stem hieroor sal hoor, dat ons preekstoele meer soos ronde tafels moet begin lyk (die titel van Mc Clure se boek: The roundtable pulpit, 1995; vgl. ook 5.4.2)

Predikers mag só 'n paradigma-skuif dalk as bedreigend ervaar. Trouens, dikwels ontmoedig predikers enige inbraak op hulle sisteem, omdat hulle diep binne-in hulleself weet dat daar fout met hierdie sisteem is. Om só uit jou veilige hawe gehaal te word, kan egter juis verrykend wees. Rudolf Bohren haal die prediker Franz Jantsch in dié verband aan:

'n Vrou bet een keer my preek oor die buweliksliefde onderbreek en my toegeroep: 'Dominee, dit hou ek nie uit nie. Ek protesteer.' Ek het daarop ingegaan deur 'n wyse man uit die gemeente te vra om bierop te reageer. Toe neem ander ook aan die gesprek deel, en die standpunte word verbelder. Ek was nie kwaad vir die vrou nie, inteendeel. Sy het verskoning gevra dat haar temperament die oorhand verkry het, maar dié voorval bet op die gemeente 'n groot indruk gemaak (1971:521-522).

Dis sekerlik nie aan te beveel dat elke preek op hierdie wyse onderbreek moet word nie, maar hierdie tussenwerpsel van die vrou is 'n gekonsentreerde voorbeeld van wat 'n gemeentegesprek kán wees. Die Gees is immers nie net aan die predikant gegee nie, maar aan die gemeente. Die charisma van die predikant is goed, maar die somtotal van gawes wat die Gees aan die gemeente gegee het, is beter. 
Ons kan nie hiervan wegkom nie: die prediking is wesenlik 'n gemeentelike, en dus kontekstuele aangeleentheid. Daarom sal ons, nie alleen omdat dit teologies belangrik is nie, maar ook kommunikasiewetenskaplik gesproke essensieel, telkens moet leer om die invoer en terugvoer van die gemeente rondom die prediking te fasiliteer. Dit blyk 'n belangrike veld vir verdere ondersoek te wees. Immers...

\subsection{Twee paar oë sien beter as een...}

Ons het nou al telkens vir besoeke aan die kunsgalery gegaan $(22,65,74$, $76,87)$. Kom ons loer nou by die kunsklas in! Die opdrag aan die studente is: skilder julle eie interpretasie van - die lewe as 'n opweg wees na... Begin! Julle het presies drie uur...

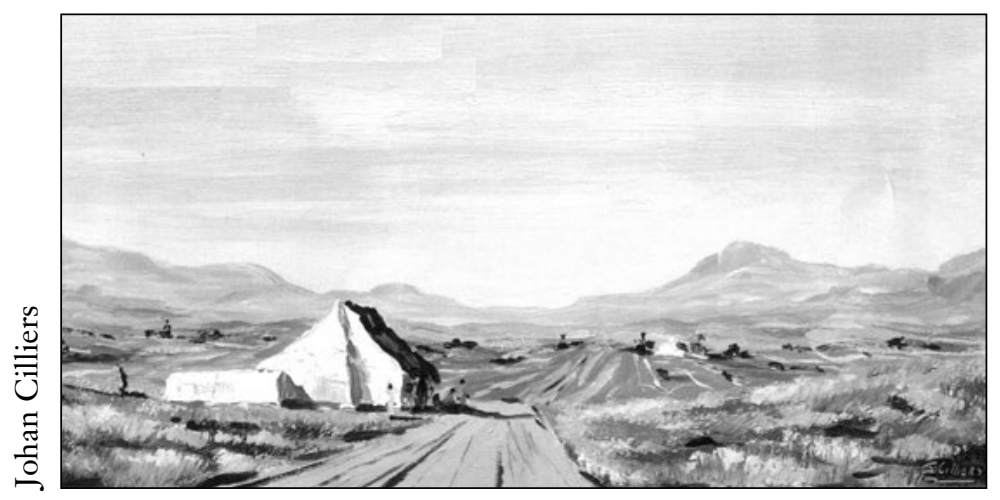

Die wonder van kuns is dit: nie één van hierdie interpretasies sal (presies) dieselfde wees nie. Die individualiteit is daar, die persoonlike voorkeure vir kleur en kwastegniek, die unieke sien van dit wat álmal sien. Watter een van dié interpretasies sou "reg" wees? Wel, dalk sou sommige (volgens óns siening!) "mooier" of "kunstiger" wees as ander, maar elkeen van daardie interpretasies het sy eie reg, en elkeen ís "reg"! Indien jy 'n geheelbeeld van die insigte van die klas wil sien, sal jy ál die skilderye langs mekaar moet plaas, en hulle in 'n sin gelyktydig "in die oog moet kry". Een tema, soveel sieninge! Twee - en meer - paar oë sien beter as een!

In die gemeente is daar mense met verskillende sieninge van God. Dit het hulle opgebou deur die jare heen, onder meer deur hulle lees van die Bybel, en die hoor van preke oor die Bybel. Hierdie sieninge van die gemeente is 'n werklikheid waarby ons nie in die prediking kan of mag verbygaan nie. Inteendeel, dit bied aan ons as predikers 'n rykdom, 'n skoon- 
heid, 'n verbrede visie op die één God in wie ons almal glo, wat ons bevry van ons eenogigheid. Gedeelde vreugde en verwondering oor die genade van God is dubbele vreugde en verwondering; ontdekkinge en sieninge van God wat jy uitruil en uitwys aan ander, is veral dié wat vir 'n lang tyd by jou bly...

\subsubsection{Ek in my klein hoekie...?}

Die ironie is net: lidmate en dominees het, veral in sommige gereformeerde tradisies, nog nie geleer om van húlle skilderplekkie af op te staan om na die ander se pogings te gaan kyk nie. Elkeen sit in sy of haar hoekie, en het in werklikheid oogklappe op vir die ruimer, mooier visie(s) op God.

Daarom benodig predikers byvoorbeeld nie alleen die insigte van ander teoloë en predikers nie, maar in 'n besondere sin ook dié van die gemeente. Predikers is prinsipieel afhanklik van ander mense wat ook iets van God gesien het; hulle kán eenvoudig nie sonder ander ooggetuies van die onsienlike God nie. Die prediking kan per definisie nooit slegs 'n individualistiese oefening of bloot 'n briljante solovlug wees nie - daarvoor is ons "onderwerp" te groot. In 'n land van siendes kan Eenoog nié koning wees nie. "Lone Rangers" hóórt nie op die kansel nie.

Daarom moet predikers hulle preekpogings doelbewus "weggee" aan mense, met die versoek dat hulle hulle indrukke daaroor aan jou moet teruggee - nie net die teoloë en predikers en letterkundiges nie, maar veral "gewone" mense, mense wat 'n aardse en praktiese blik op jou werk kan werp, en jou ten minste 'n ent weg van jou eenogigheid kan bevry. Het ons in elk geval ooit iets besit as ons dit nie eers weggegee het nie? Predikers behoort hulle te verheug oor mense wat'n totaal ander perspektief as hulle het, en wie se teologie lynreg van hulle teologie verskil. Immers, die alternatief tot jou standpunt bring jou nader aan die waarheid, of help jou ten minste om opnuut oor (jou siening van) die waarheid te besin.

Aan die een kant moet dus gewaak word teen 'n preekbegrip wat die preek monologies, outoritêr van bo na onder en onkritiseerbaar maak. Aan die ander kant moet 'n onderskatting van die prediking egter ook afgewys word. Die preek mag nie só deur die lidmaat met sy of haar interpretasies en sieninge bepaal word dat die volle raad van God nie meer sistematies verkondig word en die seggenskrag van spesifieke tekste ingekort word nie. Daar moet eerder 'n wisselwerking, 'n dialoog tussen kansel en kerkbank ontstaan, waar die heersende eenpersoon-sisteem (waarin die predikant dié persoon is) in die prediking deurbreek word, wat nie alleen die gemeente tot haar reg sal laat kom nie, maar ook die amp van die prediker self.

Daar sal inderdaad ernstig oor die amp van die prediker besin moet 
word. Moltmann maak byvoorbeeld die veelseggende opmerking dat selfs die manier waarop die prediker die kansel bestyg, iets verraai van die ampsen preekbegrip wat bewus of onbewus in daardie gemeente of kerk funksioneer. Kom die prediker met 'n waardige prosessie, of selfs net van buite die vergadering van gelowiges (deur die konsistoriedeur!) na die kansel toe, is dit simbolies van 'n Woord en 'n prediker wat van buite en van bo kom, en dus outoritêr en dogmaties onaantasbaar is. Maar staan die prediker uit die gemeente uit op om sy of haar plek voor hulle in te neem, is hy of sy één van en één met hulle, is die prediker se woorde 'n getuienis wat gebore word uit die besonderse situasie en krisisse van die gemeente, is dit 'n woord waarmee hulle kan identifiseer, en dus ook kan bevraagteken (1975: $303)$.

\subsection{2 $\ldots .$. EN JY IN JOUNE?}

Daar sal ook ernstig oor die rol van die gemeente in die preekmaakproses besin moet word.

Dit is duidelik dat hiervoor ' $n$ ander tradisie, 'n ander kultuur in die kerk geskep sal moet word, iets wat 'n hele reeks van veranderinge, en 'n pastorale proses impliseer. Want lidmate het met die huidige tradisie in die kerk grootgeword, 'n tradisie waarin hulle in 'n groot mate in die kerkbank tot swye gebring is. In die kerk hoor 'n mens immers... en swyg. Jy wys nie sómmer jou geloofskleure nie, haal nie sómmer die lap van jou skildery oor God vir ander af nie...

Deels is dit die dominee se skuld: alleen hy of sy praat, en kritiek word soms, bewustelik of onbewustelik, ontmoedig. Die uitgangspunt is: die dominee alleen het die onsienlike God gesien en sy stem gehoor; die dominee alleen mag dit artikuleer. 'n Swyende gemeente is oënskynlik tog veel gemakliker as een wat die prediking aktief beaam - of bestry! In die proses raak die gemeente egter swygsaam, en die dominee eensaam, met die groot verantwoordelikheid om mens-alleen die volheid van God op sy of haar doek vas te vang.

Natuurlik is 'n goeie aantal lidmate nie ongeneë om te sê wanneer 'n preek volgens hulle oordeel "goed" of "mooi" was nie. (In sommige gevalle sal lidmate sê dat 'n preek "swak" was - maar beslis nie vir die dominee nie!) Wanneer hierdie lidmate egter gevra word om te verduidelik wáárom die preek dan nou "mooi" of "goed" of "swak" was, kan hulle meestal slegs in algemene terme, of in cliches antwoord. Hulle is in dié sin nooit toegerus vir hulle diens en vir die opbou van die liggaam van Christus nie (Efes. 4:12). Dikwels word hierdie onvermoë verbloem met uitlatings soos: "Dit was die Woord wat gepraat het", of "Dit was die werk van die Heilige Gees”, wat natuurlik wáár kan wees maar soms ook 'n blote ontwykings- 
maneuver, juis om 'n gebrek aan dieper insig in die prediking te verbloem.

Die aanbreek van die televisie-era het hierdie onvermoë van lidmate natuurlik verder geraak: die prediking het hierdeur in 'n groot mate, by al die positiewe dinge wat 'n mens oor die televisie sou kon sê, deel geword van die lidmaat se "vermaak" (vgl. 1.3.1). 'n "Goeie" preek is dan een wat vermaaklikheidswaarde het (die prediker moet 'n tipe "kunstenaar" wees). Uiteindelik is dit 'n simptoom van lidmate se passiewe vryetydsvermaak, van hulle konsumpsiementaliteit. Hulle wil gestimuleer word, maar nie self betrokke wees nie. Dit is weer 'n uitvloeisel van die sosiale tendens van ons tyd: die (post) moderne mens se onbetrokkenheid en sogenaamde privaatheid.

Maar, die Woord van God kán nie, mág nie net gehoor en daar gelaat word nie. Jy móét daarop reageer, móét antwoord en veral doen (vgl. Jak. 1:19-27). 'n Mens dink aan die ontdekking wat Reinhold Schneider in dié verband gemaak het:

"Ek het op ' $n$ Oukersaand die Heilige Skrif in Potsdam oopgeslaan - ek het dit as 'n knaap in die Lutherse vertaling gekoop - en ek moes ná enkele hoofstukke uitvlug op die koue, donker strate. Want dit was vir my duidelik: Onder aanspraak van biérdie Waarbeid keer 'n mens se lewe om. Hierdie Boek kan 'n mens nie lees nie...jy kan dit net dóen. Dit is geen boek nie. Dit is Lewensmag. En dit is onmoontlik om ook maar net één reëltjie daaruit te begryp, sonder die besluit om dit ook uit te voer..."

'n Mens kán nie in jou hoekie met jou boekie sit en reken jy sal só by die waarheid kom nie. Dit moet gedóén word, saam met ander wat ook deur die "lewensmag" aangegryp is. Wat vir jou "teorie" was, moet "praktyk" word. Die Woord moet só weerklank by jou vind, dat dit jou hande en voete in beweging bring - saam met die hande en voete van die res van gemeente.

Die heersende toestand van eggoloosheid van die gemeente lei wel by baie predikers tot frustrasie. Dié eggoloosheid word vererger deur die wete: volgende Sondag sal die moeitevolle pad van preekvoorbereiding wéér geloop word, die Woord wéér verkondig word, die gemeente wéér die Woord "hoor"... en?

Luther was sterk onder die indruk daarvan dat die gemeente "die reg het en alle mag om alle lering van die kerk te toets". Die gemeente is meer as bloot 'n versameling van individue wat hulle "opinie" vir hulleself moet hou. Die gemeente is nie slegs ontvangers wat baie of min ontvang, soos byvoorbeeld kykers tydens 'n goeie of swak rugbywedstryd, maar dan niks verder doen nie, maar eerder gevolmagtigde beoordelaars van die verkondigde Woord. Dit is nie die uitsluitlike voorreg of vermoë van 
sekere teologiese "spesialiste" nie, maar van die gemeente in haar totaliteit. Preke - konkrete preke - is die skat van die kerk, nie die privaatbesit van predikante nie. Dit is immers die gemeente wat die geeste moet onderskei, ook dié wat op die kansel werksaam is.

In so 'n siening van die prediker en die gemeente staan of val alles nié uiteindelik met die charisma, óf gebrek daaraan, van die prediker alleen nie. Daarmee word die moontlikheid teengestaan dat die prediker se verborge motiewe en vooringenome oordele hoogty vier. Binne die gemeente (en ekumene!) is daar juis verrykende én kontrolerende kragte werksaam wat die neiging tot individualisering ten minste tot 'n gesonde mate kan beperk.

Verrykend in dié sin dat ons leer om die Skrif ook deur die oë van ander te lees: veral die marginale, veragte, vergete, stemlose ander, om so 'n beter visie te kry op die "vreemde, nuwe wêreld" van die Bybel, 'n wêreld wat altyd verrassend op ons inwerk en onverwagse nuus aan ons oordra (vergelyk Brown 1984:12).

Kontrolerend omdat die ekumeniese lees van die Bybel die beste waarborg teen 'n sektariese reduksie daarvan bied (vergelyk Fowl/Jones 1991: 29-55; 119-134). Het die kerke in Suid-Afrika ook maar net meer dikwels sáám met die Bybel geworstel, hoe anders sou ons geskiedenis nie dalk daar uitgesien het nie!

Verborge motiewe en vooringenome oordele is onvermybaar. Maar dis ook aanwysbaar, in en deur die gemeente en breë gemeenskap van die kerk. Die kreatiewe omgang met die Bybelteks het geen beter voedingsbron nie as die gemeente en kerk as volwaardige gemeente (Cilliers 1992:384-385). Dingemans druk dit só uit:

"Met andere woorden: laat het voor-oordeel tot oordeel worden in bet 'been-en-weer' van het discours tussen bet (gezamentlijk) kijken naar de 'feiten' (teksten, kunstwerken) en je eigen mening. Laat je mening corrigeren door bet kijken en praten. Laat eerst de verstaanscirkel in werking treden en laat vervolgens de verificatiecirkel opruiming houden onder de verkeerde voor-oordelen. Zo zul je de subjectiviteit wel niet helemaal kwijt raken en de objectiviteit wel niet halen, maar een getoetste subjectiviteit of intersubjectiviteit is altijd beter dan een subjectieve mening de als een verborgen agenda meeloopt in het verstaansproces. Bovendien kan het vooroordeel dat op deze wijze wordt ingebracht in het verstaansproces de tekst of het kunstwerk 'openbreken' vanuit de concrete situasie van de kijker of lezer en een nieuw perspectief op de tekst of het kunstwerk openen" (1991:75).

Predikers het gewoon die gemeente nodig, hulle kán nie preek sonder die 
gesprek met die gemeente as die lewende kommentaar op die Woord nie. Terwyl (teologiese) eksegese nog sonder die gemeente kan geskied, geld dit nie van die waarneming van die lewende God nie, aangesien Hy juis op 'n unieke wyse in die gemeente teenwoordig is. Teologiese "spesialiste" wat op 'n individualistiese wyse probeer om deur middel van 'n aantal metodologiese stappe die tydlose waarhede van die teks te ontsluit, sal presies só preek: tydloos, maar ontydig. Dis eers wanneer die leefwêreld van die gemeente op die verkondigingsproses begin inwerk, dat die Woord, die evangelie, in die tyd "ingepas", word.

\subsubsection{VAN OOG TOT OOG...}

Die prediker en die gemeente sal mekaar meer dikwels in die oë moet kyk. Hulle sal 'n vaste afspraak moet hê om mekaar "rondom die rondetafelpreekstoel" (Mc Clure) te ontmoet. Hiermee bedoel ek 'n daadwerklke gemeentelike bespreking, bevraagtekening en beaming van die prediking. Dit het spesifieke kenmerke in onderskeiding van byvoorbeeld ander vorme van gesprek, in dié sin dat dit op 'n eiesoortige wyse plaasvind, rondom 'n Woord, 'n spesifieke Woord wat 'n belofte van verandering vir mense inhou. Dit vind plaas in die skoot van die kerk, die moeder van die gelowiges, waarin daar 'n rykdom van sieninge van God teenwoordig is soos nêrens elders nie.

In so 'n gesprek sal die spesifieke situasie van die lidmaat of groep van lidmate uiteraard ter sprake kom, of ten minste van die vrae vorm wat aan die preek gevra sou kon word. Die kommunikasie-situasie, die konkrete konteks, die hoorders met hulle verstaanshorison - kortom, die totale wyse waarop die gemeente in die verlede die Woord van God gehoor en die God van die Woord gesien het, sal uiters ernstig opgeneem moet word. Immers, dit beïnvloed tog die manier waarop hulle hulle "skildery" van God maak!

Hulle kleurkeuse en verfstyl sal onvermydelik iets verraai van byvoorbeeld faktore soos die preekervaring in die betrokke gemeente, die totale, akkumulatiewe kommunikasie-effek van die prediking, oor weke en maande heen, wat maak dat hulle juis met 'n bepaalde tipe verwagting, dikwels eensydig, na die erediens kom. Daar is die "sekulêre" of postmoderne konteks, die wisselende sosiaal-historiese omstandighede, die politieke en ideologiese verhoudings waarbinne die kerk leef (Geyer 1978:478), wat maak dat juis hulle betrokke preke op 'n heel spesifieke manier inneem, anders as ander gemeentes en ander mense. Daar is die spesifieke kerklike konteks waarbinne die prediking plaasvind, byvoorbeeld dié van die erediens, die denominasie met sy tradisies, die funksionering van die amp, ensovoorts. Dit word alles op doek vasgelê!

Maar dit moet uiteindelik die Bybelteks en preek bly wat antwoorde op spesifieke vrae sal moet bied, en moontlik ander basiese vrae by die ge- 
spreksgenote sal oproep, wat egte en skynvrae, en egte en skynvisies sal moet onderskei. In so 'n preekgesprek lê die moontlikheid van 'n oorvleueling van die wêrelde van Bybelteks en hoorder opgesluit, van 'n uitklaring van spraak, begrippe, misverstande wat in dié onderskeie wêrelde sou kon leef, van 'n (voortdurende) vergelyking van dit wat by jóú op die doek is, met dit wat by ánder op die doek is, en uiteindelik met dit wat in die Skríf op die doek is...

Die preek word dan die voorwoord tot 'n gesprek. 'n Stuk verwondering wat jy met ander wil deel. 'n Siening van God wat jy aan ander wil uitwys. Maar ook 'n geleentheid om te ervaar hoe ander God aan jóú uitwys...

Só 'n gemeentelike gesprek word gerugsteun deur

- basiese opvoedkundige en kommunikasie-wetenskaplike beginsels. Volgens hierdie beginsels behou 'n mens ongeveer $10 \%$ van dit wat jy gelees het, $20 \%$ van dit wat jy gehoor het, $60 \%$ van dit wat jy gehoor, gesien en self onder woorde gebring het, en $90 \%$ van dit wat jy deur eie soeke ontdek het, waarby jy eksistensieël betrokke was - en veral waarvoor jy moes ly! Sulke statistiek weerspreek elke vorm van passiwiteit in die kerk (Dahm).

- deur empiriese ondersoeke wat gedoen is na die werking van die preek in die gemeente. Bevindinge is onder meer soos volg:

"Die ervaringe van 'n ontmoeting met Christus tydens die preek by diegene wat slegs op ' $n$ individuele verstaan aangewys is, het in die lewenspraktyk slegs op persoonlike en in minder mate op interpersoonlike vlak effek. Die ervaring van 'n ontmoeting met Christus by diegene wat in 'n korporatiewe verstaan dit onder woorde bring en groter insigte kry, het in die lewenspraktyk effek op persoonlike, interpersoonlike, arbeids- en samelewingsvlak... diegene wat in 'n korporatiewe verstaan betrokke is, word deur die groep gehelp en ondersteun om die ervaring blywender te maak en verder in die lewenspraktyk toe te pas." (Pieterse 1991: 32-33)

\subsection{Voorstelle vir 'n preekgesprek en/of Bybelstudie}

Wat hier volg, is twee praktiese wenke om bogenoemde "korporatiewe verstaan" te stimuleer, om die gesprek of Bybelstudie oor die preek en Bybelteks waaroor gepreek is, op dreef te kry. Presies hoe dit geïmplementeer moet word, sal uiteraard van gemeente tot gemeente, en van prediker tot prediker verskil. Dit bied egter 'n basis vir die gesprek, en kan aangepas word na gelang van omstandighede. 


\subsubsection{DiE “HeIDELBERG-METODE"}

\section{VRAE VIR 'N GEMEENTELIKE GESPREK}

TEKS:

PREDIKER:

DATUM:

1. Eerste indruk

- Wat was u eerste, spontane ervaring van die preek? (Bv. Troos? Skuld? Blydskap? Magteloosheid? Moedeloosheid? Ergernis? Verveling?)

2. God

- Wat het die preek oor God gesê? (Bv. dat Hy Skepper, Openbaarder, Regter, Veroordelaar, Verlosser, Voorbeeld, Oplosser van lewensprobleme, Toevlug, Vader, Moeder, Bewaarder is?)

Wat hoor u daarin van God se evangelie (belofte, goeie nuus) vir u huidige omstandighede?

3. Gemeente:

- Positief: Watter beeld van ons gemeente blyk uit die preek? (Bv. is ons geroepenes, heiliges, ingeligte volwassenes?)

- Negatief: Watter probleem of sonde van ons gemeente word veronderstel/onthul? (Bv. onsekerheid, biddeloosheid, onbetrokkenheid, ongehoorsaamheid ...?)

4. Oproep:

- Waartoe word ons as gemeente opgeroep? (Bv. tot geloof, hoop, liefde, toewyding, gebed, diens?)

- Hoe kan ons prakties gehoor gee aan dié oproep? (Bv. in gemeentelike diensaksies, in u werksituasie, huwelik, naasteverhoudinge?)

5. Samevatting:

- Sê in u eie woorde wat u as die kern van die boodskap van die preek beskou?

Wat gaan hierdie preek aan u lewe verander?

Wat in die preek is nie vir u duidelik nie? 


\subsubsection{Die “RONDETAFEL-PREEKSTOEL" (MC CluRe)}

1. Terugvoer/vooruitvoer (10 minute)

1.1 Hoe getrou was verlede Sondag se preek aan ons vorige gesprek? Moet ons aanpassings in ons metode maak?

1.2 Watter terugvoer het jy (in die gemeente) gehoor waarvan ons behoort kennis te neem?

2. Gesprek met die Bybelteks (20 minute)

1. Watter vrae het jy in verband met die historiese konteks, woorde, of outeurskap van hierdie betrokke teks waaroor gepreek gaan word?

(Die predikant sal hier 'n leidende rol speel, maar moet nie by voorbaat stereotiep wees nie!)

2. Gaan in gesprek met die outeur van die Bybelteks. Wat is hy besig om te sê? Hoe sou jy hom wou antwoord?

3. Indien die Bybelteks in die vorm van 'n verhaal is, tree in gesprek met die karakters, maar moenie jouself (te vinnig) met hulle identifiseer nie. Wat is jou reaksie op hulle dade en woorde? Wat sou jy graag vir elke karakter wou sê?

4. Let op die soort taal wat in die Bybelteks gebruik word. Wat doen dit aan jou? Hoe laat dit jou voel? Hoe sou jy daarop wou reageer?

3. Gesprek met mekaar (60 minute)

1. Bepaling van temas. Laat die groep in die lig van die Bybelteks temas (uit die arbeids-, kerklike- en persoonlike lewenswêrelde) identifiseer waaroor hulle graag sou wou gesels. Hier moet 'n "oop agenda" behou word.

2. Interpretasie. Let op hoe die groep bogenoemde temas interpreteer, wat hulle reken die belang daarvan vir hulleself, die kerk en die wêreld is. Let op verskillende en ooreenkomstige sieninge.

3. Bekragtiging. Laat die groep eienaarskap van die temas aanvaar. Gee almal 'n billike geleentheid om uit die hart te praat. Let op onderliggende gevoelens. Gee geleentheid dat mense hulle eie, en ander, stories kan vertel.

4. Verantwoording. Hierdie gedeelte mag nie vermy word nie! Die eise van die evangelie moet in die lig van die Bybelteks duidelik verstaan en aanvaar word. Vra: Watter verskil kan dié sake aan onsself, die kerk en die wêreld maak?

5. Praktyk. Hoe sit ons dit alles om in dade? Watter hulpbronne kan ons help? Wat mag struikelblokke wees? 


\subsection{Teks en konteks}

Hierdie gerigtheid op die gemeente met haar eie konteks, impliseer onder meer dat die prediking 'n eietydse en aktuele karakter verkry. Dit kan immers nie anders nie: die gemeente bring die wyer kontekste waarbinne die prediking afspeel (sosio-ekonomies, polities, ekologies, eties, ens.) in die spel van die preekmaakproses in. Daarsonder kan die prediking nié; kontekstualiteit is nie 'n luukse nie, dit behoort tot die wese van die prediking. Die lewende Woord kom altyd tot die mens van die hede (vgl. die titel van die proefskrif van BA Müller 1961). Die vraag is nie óf daar kontekstualisering moet plaasvind nie, alleen maar: hoe? Hierin gaan die Skrif ons self voor: dit is altyd 'n Woord-in-konteks, 'n vleesgeworde Woord, histories en kontemporêr. Die uitdaging van die prediking is om in die naspreke van die teks ook die konteks in die teks na te loop, en dit dan te vertaal in terme van die dinamiese ekwivalent vir die eie tyd (vgl. Müller s j: 134-135).

Dié kontekstualisering van die evangelie bly egter een van die moeilikste opdragte aan die prediker. Dit vra teologiese volwassenheid en sensitiwiteit, vra dat die prediker niks anders nie as die evangelie (en nie 'n afgewaterde reduksie daarvan nie) in die konteks laat inkarneer, dit werklik die vlees en bloed van die eie tyd laat aanneem (vir die kompleksiteit hiervan, vgl. die studie van Webb 1998: Preaching and the challenge of Pluralism). Hier moet ons veral ligloop vir preekverskynsels en -vorme wat op die oog af kontekstueel lyk, maar ten diepste juis 'n verleentheid met die eis van kontekstualiteit verraai (vir voorbeelde, vgl. 5.9). Eietydse cliché's, aktuele stopwoorde en die lukrake invoer van "sake van die dag" is nie noodwendig gelyk aan werklike kontekstualisering nie. Elke preek hoef ook nie, kán ook nie, tot in alle detail kontekstualiseer nie. Wat nodig is, is eerder dat die regte, dieperliggende eksistensiële vrae in die preekmakproses aan die orde kom, en dat die prediker dus werklik na mense in bulle konteks sal luister, só sal luister dat die prediking bulle tot geestelike volwassenheid en teologiese onderskeidingsvermoë, ja tot wysheid in die Bybelse sin van die woord kan begelei. Juis daarom kan die prediking nooit 'n eenmalige reseppie bied nie, maar dra dit eerder oor 'n lang tyd by tot die kweek van 'n lewenshouding, 'n bestaan in wysheid voor God.

Dikwels meen predikers dat hulle mense ken, dat hulle alles van mense se situasies af weet, maar meestal is dit nie die geval nie. Kontekstualisering vra tyd, vra aandag en sensitiwiteit. Nie alleen moet ons pad na die teks verlangsaam word nie, maar ook ons pad na die hart van die gemeente. Geen wonder nie dat die opdrag om te kontekstualiseer dikwels maar eerder in die prediking vermy word nie.

Maar, ons kán die roeping om die evangelie ook in die prediking te kon- 
tekstualiseer, nie systap nie. Ons moet mense tref waar hulle ís, of ons mis hulle. Die vraag na die verhouding tussen teks en konteks (of: God en mens) begelei die prediking, en trouens die breë spektrum van teologiese loci al van die begin af. Die preek is soos 'n spantou tussen die twee punte van die boog - as een kant nie vas is nie, kan die pyl nie vlieg nie! Dié spanning duik telkens weer op - soos ook in resente homiletiese literatuur. 'n Goeie voorbeeld is die twee hoofreferate wat tydens die konferensie van die Societas Homiletica in Washington (1999) gelewer is. Die tema was: Preaching grace in the human condition, en die twee sprekers het breedweg gesproke die twee punte van die boog verteenwoordig. Mary Catherine Hilkert ('n Rooms-Katolieke teoloog) het 'n sterk saak daarvoor uitgemaak - oorvereenvoudig gesê - dat ons in die prediking primêr moet uitgaan van die toestande van menslike ellende, om daar te soek na tekens van God se teenwoordigheid, en hulle dan aan te wys en te benoem as genade, as eggo's van die evangelie. Sy het dan ook 'n boek geskryf met die titel: Naming Grace. Preaching and the sacramental Imagination (1998), waarin sy as 't ware twee teologiese balle in die lug wil hou. Aan die een kant: Contemporary buman experience can disclose new dimensions in the story of Jesus. En, tegelykertyd: The Gospels and the history of Jesus limit and focus the contemporary retelling of the story. (55)

Charles Campell was die ander hoofspreker. Weereens ongenuanseerd gesê: Campell neem as uitgangspunt "Preaching Fesus" (ook die titel van sy boek, 1997). Volgens sy oortuiging kom God ook deur die prediking die toestand van menslike ellende binne en vra daar om gehoor en gehoorsaam te word. Hy sluit as post-liberale denker aan by Hans Frei, en sê onder meer: For Frei the starting point is not human experience or existence, but rather the specific, unsubstitutible identity of Jesus Christ, which is rendered in the interplay of character and incident in the gospel narratives. (57). Hy ontwerp dan verder 'n model vir narratiewe prediking as teenvoeter vir prediking wat op 'n kognitiewe-proporsionele wyse óf met die Bybelteks, óf Christelike temas en dogmas óf die Christelike tradisie omgaan.

Verskeie ander homilete beoefen hulle teologie presies binne hierdie spanning. Leonora Tubbs Tisdale het byvoorbeeld 'n boek geskryf met die provokatiewe titel Preaching as local theology and folk art (1997). Sy bied onder meer sewe weë aan waarvolgens die gemeente geëksegetiseer kan word om kontemporêre prediking te verseker. Stephen Farris betitel sy boek: Preaching that matters (1998), en hy worstel met presies dieselfde spanning: om analogieë tussen die wêrelde van die teks en die gemeente te vind (hy stel ses stappe voor), en so sou ons op die homiletiese ry kon afgaan (vgl. bv. ook E Jonker 1998: Van verstaan naar vertolken; ook die interessante boek van Schreiter 1986: Constructing Local Theologies). Dis in elk geval belangrik dat teenoorgestelde eksponente met mekaar in gesprek 
bly en nie te gou 'n kompromis bereik nie. Daarvoor is daar teologies en eksistensieel te veel op die spel (vgl. Bos 1999: 245).

\subsubsection{KONTOERE VAN KONTEKSTUALISERING}

Die volgende is na my mening wel hier van belang:

- Dit behoort tot die wese van die prediking om telkens die taal van die Skrif vir die tyd te herformuleer. Daarmee word die moederspraak van die teks nie prysgegee nie, maar juis in haar volle konsekwensies deurgetrek. Die taak van die prediking slaan hier na twee kante toe: om die gemeente opnuut hulle egte moedertaal te leer, én hulle te begelei in die eietydse herformulering daarvan. In die prediking kán ons nie anders nie as om lokale teologieë te vorm of te help vorm, en self daardeur gevorm te word nie. Prediking kan só "Bybels" in taal en idioom wees, dat dit helaas onverstaanbaar vir konkrete mense van 'n spesifieke tyd word. Jy kan só "korrek" wees, dat jy verkeerd is. Soms moet minder korrektheid (Cicero noem dit "bestudeerde slordigheid") die weg open tot verstaanbaarbeid - wat tog nou nie weer as 'n alibi vir algehele grammatikale of homiletiese slordigheid gesien moet word nie! Die punt is: die evangelie is verstaanbaar. Dit kom altyd tot mense hier en nou (bic et nunc). God het Hom aangepas in die idioom van die tyd (vgl. maar net die taal van die Bybel). Daarom kan die prediking ook nie anders as om verstaanbaar te wees nie - wat egter weer nie beteken dat die kompleksiteit van die lewe oorvereenvoudig moet word nie. Die taal van Sion/Kanaan is in dié sin nie "heilig" nie. Dit neem eerder die kontoere van die tyd aan, inkarneer in die lokale gemeente en omgewing - en vind so sy doel. Kontekstuele prediking vra verstaanbare prediking, vra daarom 'n openheid vir die hartklop van die eietydse - wat jy dikwels op sy helderste in die kuns van die tyd (literatuur, films, ens) hoor. Van die grootste epifanieë wat'n prediker kán beleef, is in die kunsgalery of op straat (op die "markplein"), tussen gewone mense. Hierdie inkarnering van die woorde van die prediking in die eietydse, het uiteraard grense: die evangelie van die teks bly altyd 'n kontra-evangelie, wat as sodanig ook kontra dit wat gebruiklik of mode-van-die-tyd is, kan staan (vgl. verder hieroor 5.5.2).

- Dit behoort ook tot die wese van kontekstuele prediking om die vorm van die prediking voortdurend te heroorweeg. Die feit dat die Bybelse teks deurslaggewend is vir die vormgewing van die preek (hoofstuk 4), beteken nie dat alle preke oor spesifieke tekste altyd dieselfde vorm moet hê nie. Benewens die kreatiewe vryheid wat die teks bied, vra die konteks ook telkens om 'n homiletiese ratwisseling, om verantwoordelike vormvariasie binne die kommunikatiewe strategieë wat aan die orde van die 
dag is (vgl. die studie van Bluck 1989: Christian Communication Reconsidered: 32-43). Wel mag die vorm nooit'n doel in sigself word nie, maar moet dit steeds diensbaar aan die verstaanbaarheid van die preek bly. Tegniek mag nooit oor die teks heers nie, en die aanleer van 'n aantal kommunikasiestrategieë mag nooit die arbeid aan, en invloed van die teks in die prediking op die agtergrond skuif nie. Jy kan nie - hoef nie - die Bybel met joernalistieke flair te probeer opkikker om dit "aktueler" en "lewendiger" te maak nie (Miskotte 1941:66). En tog lê hier'n wêreld wat ontgin kan word. So 'n openheid vir die kommunikatiewe omgewing is niks nuuts nie. Dis welbekend dat Augustinus byvoorbeeld ryklik, en op die oog af gevaarlik baie, geleen het by die retoriese strategieë van Cicero. Hy het dit egter telkens aangepas by die aard van die teologie en ook die profiel van die mense van sy tyd (dalk sy bekendste: prediking as docere, delectare en movere: onderwysend, onderhoudend en oortuigend; vgl. Den Dulk 1999: 15 e.v.). Die realiteit is: ons leef in 'n tyd waarin kommunikasie op radikale ander maniere plaasvind as tien of twintig jaar gelede. Die era van die rekenaar spoel oor ons heen. Binne die volgende vyf jaar gaan daar'n ongekende ontploffing in die informasietegnologie plaasvind (vgl. hoofstuk 1:1.3.1). Die prediking kán nie anders nie as om ook hier inkarnerend teenwoordig te wees en die vrugte daarvan te geniet nie. Indien ons kommunikatiewe teorieë en praktyke stol op 'n ewige gister, is die skrif vandag aan die muur vir kontekstuele prediking. Verskeie resente homilete is diep onder die indruk hiervan en sluit byvoorbeeld doelbewus aan by heersende kommunikasiewetenskaplike en retoriese strategieë: Buttrick met sy Homiletic: Moves and structures (1987) is deurdrenk daarvan. Hy benut onder meer eksplisiet die wyse waarop 'n goeie film die boodskap aan die kyker oordra wanneer hy praat van "opening, closing, association and disassociation moves" (294 e.v.). Die kamera word gebruik as analogie vir die wyse waarop ons waarneming - ook op neurologiese vlak - plaasvind, wanneer ons 'n prentjie "sien". Dit het 'n baie groter uitwerking as die blote inneem van steriele "inligting". So moet die een prentjie na die ander mekaar ook in die prediking in verskillende "moves" vaartbelyn opvolg, wat meewerk tot 'n holistiese en estetiese waarneming (vgl. ook Cilliers 1998:119). Eugene Lowry - om nog 'n enkele naam te noem - werk met 'n tegniek wat al vroeër in die teaterwêreld ingevoer is (die sg. Entfremdungstechnik): om die vreemde, die paradoksale van die (Bybelse) boodskap nie met allerhande vooropgesette vorms in die prediking te laat stol nie, maar om die verrassende daarvan juis enduit, ook in die vormgewing, te ontgin - ter wille van kommunikasiewetenskaplike kontekstualisering (1980:76 e.v.).

- Ten diepste gaan dit hier oor die bermeneutiese vaardighede van die prediker en gemeente. Wie nie prinsipieel hermeneuties dink nie, kan nie 
kontekstualiseer nie. In die prediking staan of val baie met die wyse waarop die prediker hom - of haarself - in die sg. "hermeneutiese sirkel", oftewel dialoog tussen teks en konteks, en uiteindelik ook in die gesprek tussen prediker, gemeente en God plaas. Bo het ek die dialoog 'n "spanning" genoem (soos die spantou van 'n boog). In 'n sekere sin ís dit 'n spanning, wat nooit ontlont mág word nie. Teologie wat nie met paradokse werk nie, is futloos. Wie die relasie tussen teks en konteks té gou wil platstryk, demp die bruising van kreatiwiteit. Daarmee word nie gesê dat die Woord nie sélf die krag het om 'n spesifieke konteks binne te dring en te omvorm nie. Alles hang gelukkig nie af van die prediker se hermeneutiese briljantheid nie. Die Woord is immers as sodanig nooit tydloos nie, en word as swaard met twee skerp snykante nooit stompgemaak deur die muur van tydsgrense nie. Daarom is dit in 'n sekere sin 'n valse teenstelling as predikers vra: Moet ons by die teks, of by die situasie begin? God is lankal, ook via die teks, op pad na elke situasie toe. Daar ís geen spanning nie, die pole is oorbrug; Christus is geïnkarneer, en die Gees is uitgestort. Dit ís so. En tog hét die prediker 'n hermeneutiese roeping, 'n verantwoordelikheid om die dialoog tussen teks en konteks te dien, om juis hierdie koms van God na, en sy inwoning in die werklikheid aan die gemeente uit te wys (vgl. Cilliers 1998: Die uitwysing van God op die kansel). Predikers is brugbouers, omdat die Brug gebou is. Hulle is onophoudelik op pad, heen-en-weerreisigers tussen die wêreld van die teks en die wêreld van die konteks. Hulle is mense wat die vrae van die teks en die konteks voortdurend op mekaar laat instem, omdat die Gees die groot Instemmer is. Sonder hierdie instemming kan teks en konteks dalk by mekaar verbypraat. Ja, wie nie sy of haar hermeneutiese roeping vervul nie, kan gevaar loop om die "regte" teks vir die "verkeerde" tyd te preek, of die "verkeerde" teks vir die "regte" tyd! Predikers wat nie hermeneuties volwasse en sensitief is nie, kan tekste en waarhede belangriker begin ag as mense, of kan mense oor tekste en waarhede laat heers. Wanneer die hermeneutiek nie klop nie - wanneer teks en konteks mekaar mis - is valse profesie meestal die gevolg. Predikers lees dikwels die uur (van God se koms) verkeerd. Hulle is nie profeties betyds nie. Hulle hermeneutiese tydsberekening is uit. O, hulle mag wel korrekte, tydlose waarhede verkondig, maar dis ontydig, en daarom vals. Gister se teologie verword in die valse profeet se mond tot vandag se ideologie. Karl Barth noem sulke mense gewoon dwase:

Dwase mense is altyd of te vroeg of te laat. Hulle slaap wanneer bulle wakker moet wees, en is wakker wanneer bulle moet slaap. Hulle swyg wanneer hulle moet praat en praat wanneer dit beter is om te swyg. Hulle 
lag wanneer bulle moet buil en huil wanneer bulle getroos beboort te wees en gerus maar kan lag. Hulle werk wanneer bulle moet bid en bid wanneer slegs werk die verskil kan maak. Hulle bedink alles op die verkeerde tyd; sê alles aan die verkeerde mense; doen alles in die verkeerde rigting; doen altyd weer ' $n$ keuse vir die ingewikkelde, maar irrelevante dinge, terwyl die eenvoudige, maar noodsaaklike gevra word. Hierin lê die briljantheid van die dwaasheid" (1958: 413)

Wat van ons as predikers in hiérdie uur gevra word, is wysheid. Dít kan ons slegs leer op die skoot van die gemeente, wat die moeder van alle gelowiges is (Calvyn).

\subsubsection{DRIE HERMENEUTIESE TRADISIES}

Bogenoemde hermeneutiese vaardighede sou na my mening breedweg binne drie teologiese tradisies verstaan en gekultiveer kon word, naamlik inkarnasie, her-interpretasie en transformasie (vgl. ook Troeger 1999:93-95).

- Inkarnasie: in die lig van die menswording van Christus (Joh. 1:14) kan ons as predikers nie anders as om elke tydvak uiters ernstig op te neem nie. 'n Mens dink aan Karl Barth se bekende beeld van die Bybel in die een hand, en die koerant in die ander. Ons het geen reg om vir mense te preek as ons hulle nie verstaan, of ten minste wil verstaan nie. Die inkarnasie van Christus onderstreep God se werkswyse, sy aanpassing by mense, sy tegemoetkoming in sy openbaring, sy indaal in ons vleeslike bestaan, sy leegmaak van Homself - tot die dood toe (Fil. 2:6-8). Dit het niks met kontekstualisme - 'n volledige, kritieklose eenwording met mense, ook in hulle dwalinge en sonde - te make nie, maar wel met die kontingensie van God se handelinge: Hy bly skeppend en herskeppend in die loop van die geskiedenis vír, by en in ons.

- Her-interpretasie: dis 'n bekende feit dat Jesus byvoorbeeld nie net die tradisies van sy tyd deur en deur geken het nie, maar dat Hy dit ook voortdurend in die lig van sy eie optrede gerelativeer én geradikaliseer het (vgl. bv. Matt. 5!). Tradisies - of historiese fases - het sterk én swak punte, en die taak van die prediking is na my mening onder meer om die tydsgees telkens weer in die lig van God se Koninkryk te her-interpreteer, om te onderskei waarop dit wérklik aankom (vgl. 1.2). God pas nie net aan by mense nie; sy evangelie is ook 'n struikelblok, 'n skandaal wat wars staan op dit wat gangbaar is (vgl. 1 Kor. 1:18-31). God se estetika bots meermale met dié van die tydsgees (vgl. Babin 1991:144 e.v.; ook Moltmann 1971:61). 
The Peruvian Christ (datum onbekend)

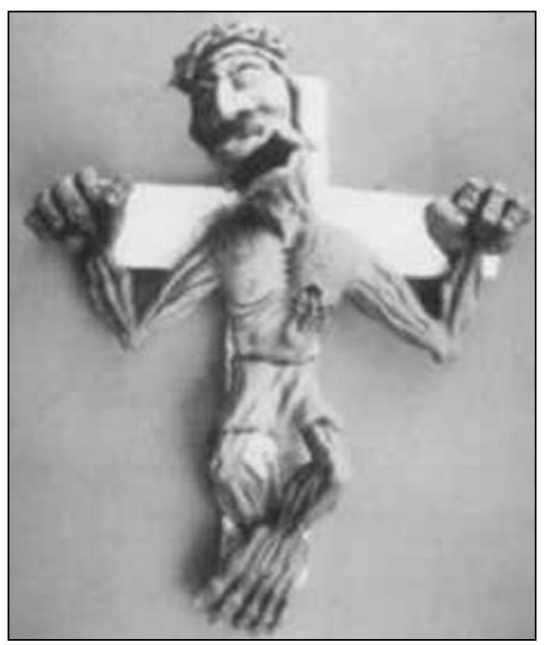

Hierdie botsing word aangrypend uitgedruk in die kunswerk getiteld: The Peruvian Christ. Dis 'n skepping van die Franse Rooms-Katolieke kommissie vir kommunikasie, en het met sy eerste verskyning 'n skandaal veroorsaak. Die kunswerk vertoon 'n Christus wat feitlik gestroop is van sy vleis, en in werklikheid aaklig is om na te kyk. Mense het geprotesteer en gesê: "Die kommissie het geen reg gehad om só 'n kunswerk die lig te laat sien nie. Dis nie 'n uitbeelding van Christus nie. Dis 'n padda." Sonder dat hulle dit besef het, het hulle 'n teks uit Jesaja geparafraseer: Hy het nie skoonheid of prag gehad dat ons na Hom sou kyk nie, nie die voorkoms dat ons van hom sou bou nie... iemand vir wie die mense die gesig wegdraai $(53: 2,3)$. Die estetika van die kruis her-interpreteer óns esteti$\mathrm{ka}$, wat meestal 'n estetika van die media, en daarom van skoonheid en sukses is.

- Transformasie: as predikers van die evangelie gaan ons uit van die veronderstelling dat die werklikheid on-af is, onvoltooid, “open-ended". Hierdie veronderstelling rus op die geloof in die opstanding van Christus en die uitstorting van die Heilige Gees. Die geskiedenis en die werklikheid is nié bloot 'n nimmereindigende mimiek in 'n spieël-in-'n-spieël nie. Ons dwaal nié rond in 'n labirint van ewige onoorspronklikhede nie. Prediking is 'n hoopvolle handeling (vgl. 2.3). In hierdie sin is die prediking 'n voor-spel, 'n prelude tot die finale en ewige spel van die verloste skepping saam met God. Daarom moet predikers van die evangelie ook die werklikheid in die lig van die parousie relativeer, en inkarnerend en her-interpreterend met die werklikheid in die hoop van die finale transformasie bly worstel. Wie die parousie verwag, speel die spel van die prediking juis as tussen-spel tussen dit wat is, en dit wat kom, 
wetende dat ons nog nie dáár is nie. Maar omdat ons ook - deur die opstanding van Christus en die uitstorting van die Gees - reeds deel het aan die einde, vervul dit ons met'n onuitspreeklike en heerlike blydskap (1 Pet. 1:9; vir die verband tussen prediking en spel, vgl. 2.6).

Die vraag waarby ons nou moet stilstaan, is: hoe lyk die (breër) konteks waarbinne die prediking in Suid-Afrika afspeel? Wat is die agtergrond waarteen ons inkarnerend, her-interpreterend en transformerend die Woord moet verkondig? Hoe beïnvloed hierdie konteks die prediking? Uiteraard sal dit sekerlik eiendomlike kenmerke in verskillende gemeentes aanneem, maar die volgende faktore is na my mening onontwykbaar in ons nadenke oor ons konteks:

\subsection{Kontoere van 'n spesifieke (Suid-Afrikaanse) konteks}

'n Samelewing aan die bloei. Só sou 'n mens waarskynlik onder meer die Suid-Afrikaanse samelewing kon beskrywe. Nege jaar ná die transformasie van Suid-Afrika na 'n demokratiese samelewing staar die land 'n vloedgolf van kriminaliteit in die oë soos selde tevore in sy geskiedenis, met misdaadstatistiek wat die bloed laat stol. Die kanse is trouens goed dat iemand êrens in Suid-Afrika 'n gewelddadige dood kan sterf nog voordat jy hierdie sin behoorlik klaar gelees het. Voordat jy die einde van hierdie bladsy gehaal het, is iemand moontlik in sy of haar eie motor ontvoer, verkrag en om die lewe gebring...

Nee, dis ongelukkig nie oordrewe nie. Elke sewentien sekondes word 'n vrou in Suid-Afrika verkrag. In die volgende halfuur eenhonderd en twintig. Trouens, een uit elke drie vrouens sal - indien die huidige tendens volgehou word - in die loop van hulle leeftyd verkrag word. En een uit elke sewe mans...

Berigte soos die volgende bied min troos en nog minder vooruitsig:

"Daar is min of geen aanduiding nie dat misdaad, met die uitsondering van moord, in Suid-Afrika aan die afneem is.

Uit die jongste syfers verskaf deur die Suid-Afrikaanse Polisiediens blyk dit dat die voorkoms van misdaad op baie hoë vlakke hoogstens gestabiliseer het, maar voortduur.

Die jongste jaarlikse misdaadsyfers verstrek deur die SAPD se misdaadinligting en -analisesentrum wat tot Maart vanjaar (2000) strek, skets 'n somber verhaal.

Vergelykende syfers van die 20 ernstigste misdade dui daarop dat 
van 1994 (die eerste ses maande van elke jaar) tot in Maart vanjaar, misdaad in net 4 van die 20 kategorieë afgeneem het, in 9 het dit gestabiliseer en in 7 was daar 'n toename.

In die misdaadopnames geneem van Januarie tot Maart vanjaar, blyk dit dat daar reeds sowat 143 meer misdade per 100000 van die bevolking gepleeg is as in 1994, en sowat 75 meer as verlede jaar (1999).

Dié landswye syfers is volgens die bevolkingsgetalle van 1996 bereken. Al die syfers is geneem vir elke 100000 mense van die totale Suid-Afrikaanse bevolking. Moord en poging tot moord het in die geheel van 1994 tot nou aansienlik afgeneem. Daarenteen het diefstal met verswarende omstandighede toegeneem.

Verkragting het gestabiliseer op sowat 31,3 per 100 000. Ernstige aanranding het dramaties met 24,6 tot 158,3 toegeneem. Huisbraak het baie toegeneem met byna 29 inbrake meer in die drie maande tot dusver vanjaar, as in 1994. Inbrake by sake-ondernemings het weer gestabiliseer, maar is nog hoog op 53,2.

In 1994 is sowat 61,8 motors per 100000 gesteel. Dit het nou effens afgeneem tot 57 . Bedrog, vervalsing, wantoeëiening en verduistering wat in 1997, 1998 en 1999 effens afgeneem het, het weer met sowat 2 per 100000 mense toegeneem tot 41,4.

Misdade wat almal oor die afgelope ses jaar en paar maande gestabiliseer het, was die onwettige besit van vuurwapens, dwelmverwante misdade en bestuur onder die invloed van drank of dwelms.

Tot dusver blyk dit dat motor- en vragmotorkapings, bankrooftogte en transito-rooftogte wel in die afgelope paar jaar gestabiliseer het.

'n Vergelyking van die jongste syfers met internasionale misdaadtendense was onmoontlik omdat Interpol se jongste vergelykende syfers net tot 1997 strek." (Rapport, 28 Mei 2000).

Hóé 'n mens ookal hierdie statistiek wil interpreteer, een ding bly duidelik: die voorkoms van geweld en ander vorms van kriminaliteit is steeds buitengewoon en onaanvaarbaar hoog in Suid-Afrika. 'n Mens besef wel deeglik dat dit, gegewe ons geskiedenis in Suid-Afrika, veel erger kon gewees het. Dat ons op só 'n relatiewe vreedsame wyse deur 'n transformasieproses kon gaan sonder om in 'n burgeroorlog vasgevang te word, ís inderdaad niks minder as 'n wonderwerk nie. Dat ons binne die bestek van 'n aantal jare deur veranderinge kon gaan wat in ander lande veel langer, selfs eeue geduur het, is merkwaardig. En tog mag hierdie wete en hierdie dankbaarheid wat in ons leef, ons nie in 'n dowwe berusting oor die huidige situasie laat verval nie. Inteendeel. 
Volgens alle aanduidings is bogenoemde misdaadstatistiek maar net die ore van die seekoei. 'n Groot persentasie misdade word nooit aangemeld nie. Hoewel statistiek meestal relatief en soms selfs misleidend kan wees, is dit duidelik dat daar êrens 'n groot skroef los is in die waardesisteem van die Suid-Afrikaanse nasie. Dit wat die amptelike statistiek haal, is trouens bloot 'n simptoom van 'n dieperliggende probleem, 'n aanduiding dat die samelewing se norme (etos) aan die verbrokkel is, of ten minste onder groot druk verkeer. 'n Totale gebrek aan respek vir lewe en eiendom, vir waarheid en geregtigheid kom tot uitdrukking nie alleen in ekstreme geweldsmisdade nie, maar ook in verskynsels soos witboordjiemisdaad, bedrog en 'n verskeidenheid van verwante oortredings.

Willie Esterhuyse se opmerkings in dié verband stem 'n mens tot nadenke:

"KPMG se bedrogopname (1999) waarby ongeveer 2000 SuiderAfrikaanse maatskappye betrek is, skilder 'n uiters kommerwekkende prentjie...

Volgens die opname, waarin die woord 'bedrog' in sy breeds moontlikste sin geïnterpreteer word, word maatskappye veral van binne bedreig deur oneerlike werknemers. Nie minder nie as $75 \%$ van die bedrog wat geïdentifiseer is, word deur personeel of werknemers gepleeg. Korrupsie speel 'n groot rol. Ongeveer $48 \%$ van die bedrog wat plaasgevind het, was die gevolg van sameswering tussen personeel en derde partye.

Maatskappye is nie optimisties dat dit sal verbeter nie. Van die deelnemers is $86 \%$ oortuig dat bedrog sal toeneem. 'n Skrale 3,5\% reken dit sal afneem en $7 \%$ sê dit sal dieselfde bly.

'n Mens moet versigtig wees met veralgemenings. Dit is ook so dat sommige maatskappye beter as ander daarin geslaag het om 'n gesonde etiese kultuur in hul maatskappye te vestig.

Dit wil egter voorkom asof eerlikheid, integriteit en verantwoordelikheidsin nie deugde is wat besonder sterk in die sakewêreld figureer nie. Die konsep van die 'betroubare werknemer' is by ons in die gedrang.

Die redes hiervoor is insiggewend. Ekonomiese druk kry die hoogste persentasie $(71 \%)$.

Nommer twee is iets waarop ons nie trots kan wees nie: 'n Totale gebrek aan voldoende strafmaatreëls en die afdwingbaarheid van straf $(60 \%)$. Daarom is dit nie vreemd dat gebreke in die strafregstelsel die derde plek kry (57\%) nie.

Die vierde plek word ingeneem deur 'n faktor wat - sou dit sterker word - vir Suid-Afrika se ontluikende demokrasie net skadelike gevolge kan hê. Dit is: 'n verswakking van die waardes van die samelewing. 
Dit is iets waarvan ons reeds in Suid-Afrika bewus is. Misdaad dui op 'n erosie van respek vir lewe, vir ander se eiendom en selfrespek. Rolmodelle is nie meer onderwysers, predikante, kultuurleiers of politici nie. Vir baie jongmense het skurke en skelms die rolmodelle geword. Ons beleef ' $n$ tyd waar selfs die minimum voorwaardes vir 'n moreel verantwoordelike samelewing in die gedrang is.

Die regering kan weinig hieraan doen - behalwe om toe te sien dat wetstoepassing geskied en die strafregstelsel werk. 'n Regering wat egter op die gebied van morele waardes voorskriftelik optree, is gevaarlik.

Die burgerlike samelewing en sy instellings - waaronder die geloofsgemeenskappe, opvoedkundige instellings, die private sektor en die media - sal die voortou moet neem in die verstewiging van die waardes en morele spiere van ons samelewing...

Daar moet egter onthou word dat bestuur deur waardes nie 'n kitsoplossing is nie. Dis 'n lang proses wat toewyding vra. Dis egter wel een van die wapens teen die saboteur van binne." (SakeBurger, 17 Mei 2000).

Kriminaliteit is inderdaad 'n komplekse probleem, met vele gesigte. Die oorspronge daarvan is uiteenlopend, en kan faktore insluit soos opvoeding en groepsdruk, ekonomiese agtergronde en agterstande, psigologiese disfunksies en ideologiese indoktrinasie. Die suksesvolle bekamping daarvan blyk nóg ingewikkelder te wees. Dis duidelik dat effektiewer regsprosesse en strenger polisiëring, gerugsteun deur toepaslike wetgewing, onontbeerlik is. Net so is dit onverhandelbaar dat sosio-ekonomiese faktore soos armoede en werkloosheid, wat'n teelaarde vir kriminaliteit vorm, met alle beskikbare middele teengewerk moet word.

Dis presies hier waar Suid-Afrika egter met 'n bykomende probleem moet worstel - die roue werklikheid van vigs. Vigs vererger die bose siklus van armoede en kriminaliteit op 'n ongekende skaal - en dis duidelik dat Suid-Afrika nog maar aan die begin van sy vigsepidemie is. Die uitwerking wat vigs in die nabye toekoms op die land gaan hê, is werklik skrikwekkend. Dis duidelik dat feitlik alle sektore van die samelewing daardeur geraak en inderdaad lamgelê kan word, van die staatsmasjinerie tot die handhawing van wet en orde tot die private sektor tot die beoefening van menseregte tot die gesondheidsdiens en die ekonomie - 'n verlamming wat net maar kan meewerk om die land nog verder te stoot in sy afwaartse spiraal van etiese afstomping en wetteloosheid. Die prentjie wat op die dertiende internasionale vigskonferensie in Durban geskets is, is - ook en veral wat Suid-Afrika betref - werklik donker: 
"Suid-Afrika het, ongeag sy bevolkingsgetal, die meeste HIV/vigsdraers van enige land ter wêreld.

Van die 4,2 miljoen lyers is 2,3 miljoen vroue - ook 'n wêreldrekord. Dit verteenwoordig 19,2\% van die land se mense.

Trouens, die vigsprobleem het só vererger dat die 4,2 miljoen syfer twee jaar vroeër bereik is as wat aanvanklik voorsien is. Twee jaar gelede het die VN gemeen daar sou 3,6 miljoen HIV/vigslyers in Suid-Afrika wees.

Teen 2006 sal ewe veel Suid-Afrikaners aan vigsverwante siektes sterf as aan alle ander oorsake gesamentlik.

Teen die huidige koers sal byna 6,5 miljoen Suid-Afrikaners teen 2010 HIV-positief wees.

Die onmiddellike bedreiging is dat miljoene Suid-Afrikaners aan die vooraand staan van die grootskeepse omsetting van hulle HIVstatus tot vigs - en onvermydelike dood.

Die bedreiging van onstabiliteit wat dié toedrag van sake inhou, lê daarin dat die land op die punt staan om 'n groep mense te verloor wat die ekonomie en die staat aan die gang hou en uit wie se geledere die volgende geslag leiers sou moes kom...

Maatskaplike onstabiliteit sal toeneem in die afwesigheid van duidelike politieke leierskap. In gemeenskappe wat voor 'n ekonomiese krisis staan en gebrek ly aan politieke leierskap, te midde van die teenwoordigheid van vigs en die stigma daaraan gekoppel, kan revolusie die gevolg wees...

Nog 'n gevolg is die moontlikheid dat die land en sy mense in 'n staat van lusteloosheid, ontkenning en 'n miskenning van aanvaarde etiese maatstawwe kan verval..." (Berig in Rapport, 2 Julie 2000)

Wanneer 'n mens só na die statistiek kyk, moet jy een ding nie vergeet nie: dit handel hier oor meer as net syfers op papier. Dit gaan oor mense. Mense met gesigte en name en gesinne. Mense wie se stuk lydingsgeskiedenis beswaarlik statisties uitgedruk of "verwerk" kan word. En dis juis hiér waar die kerk - ons - geroep is om 'n verskil te mag maak, om juis in hierdie land met sy geweld en bedrog en vigs en alle ander menslike vorme van lyding en verval, die evangelie te verkondig, die goeie nuus van die verlossing van sonde in al sy verknegtende vorme, en van gehoorsaamheid uit dankbaarheid...

In die naam van hierdie evangelie sal alles in die stryd gewerp moet word om die donker kringloop van armoede en immoraliteit, met inagneming van die historiese oorspronge daarvan, teen te werk. Ons sal moet begryp dat die Suid-Afrika van vandag nie uit 'n vakuum ontstaan het nie, maar uit 'n geskiedenis van geweld gebore is. In die naam van hierdie 
evangelie sal die vernietigende ekonomiese gevolge van armoede en immoraliteit beveg moet word. Maar dit alleen is nie genoeg nie. Mense se lewensbouding, bulle basiese instelling, moet verander word. Individue, maar ook gemeenskappe, moet met 'n nuwe waardesisteem toegerus word, anders skiet strenger wetgewing en veranderde lewensomstandighede jammerlik te kort. Wat nodig is, is 'n holistiese benadering tot ons knellende SuidAfrikaanse probleem, 'n benadering waarin die media, onderwys, private sektor, maar ook die kerk, en dan spesifiek ook die verkondiging in en van die kerk, 'n bepaalde rol het om te speel.

\subsection{Skuldbelydenis - 'n kreet om 'n nuwe Suid-Afrika}

Die vraag is nou: Hoe moet die kerk - en predikers - op só 'n konteks reageer? Na my mening op minstens twee maniere. Eerstens - en ek weet dis geen gewilde weg nie - deur sonde só te verkondig dat dit tot egte skuldbelydenis lei, en tweedens: deur die gebod van naasteliefde só te preek dat dit tot gehoorsaamheid in, en beiliging van die totale Suid-Afrikaanse werklikbeid lei.

Eerstens staan ons dan stil by die verkondiging van sonde en skuldbelydenis. Wet en evangelie bly middele in God se hand, wat Hy gebruik soos en wanneer Hy wil, onder meer ook om 'n sondebesef by ons wakker te maak. Een ding moet ons as predikers egter goed verstaan: ons kan op géén manier 'n sonde-oortuiging by mense "bewerkstellig" of "manipuleer" nie. Emosievolle uitsprake en reaksies is nie noodwendig identies met 'n egte sondebesef nie. Dit is alleen die Gees wat oortuig van sonde, reg en oordeel (Joh. 16:8). Mense sal uiteraard verskillend op dié sondeoortuigende werk van die Gees reageer. Hier is geen resep of metode voor te skryf nie.

Hoe 'n mens ookal reageer - die uiteinde van 'n diepgaande sonde-oortuiging sal 'n verandering van gesindheid en daad wees, en wel ook nie net eenmalig nie, maar voortdurend. Wie sy of haar sonde begin insien, roep om genade, om verandering, en hierdie roepe word 'n lewenswyse. Dis veel meer as net 'n eenmalige en oppervlakkige gevoel van jammerte, eerder 'n daaglikse boetedoening (Luther).

Indien ons ' $n$ werklike verandering in die Suid-Afrikaanse samelewing wil sien, sal ons die volle implikasies van die wet in sy eerste funksie moet preek. Dis nie 'n maklike weg nie. Sonde was nog nooit 'n modewoord nie. Maar sonde is ' $n$ werklikheid wat homself universeel in al ons menslike doen en late laat geld, ons in die skuld dompel voor God en teenoor mekaar, wat 'n mag oor ons lewens het wat ons meestal nie eers begín verstaan nie. Ja, ons bet nog nie goed oorweeg hoe swaar die gewig van ons sonde is nie (Anselmus). 
Daarom ís daar plek vir ware oordeelsprediking as vorm van wetsprediking, solank dit binne sy teologiese raamwerke verstaan word. "Oordeelsprediking" wat byvoorbeeld berus op 'n starre wet-evangelie skema (om sondaars te "maak" voordat jy hulle in verlostes kan "verander"), of bloot klein-burgerlike- of tydskritiek uitspreek sonder om dit in die lig van God se oordeel te plaas, doen baie meer skade as goed. Dit versterk net ons moralistiese waan van selfrestourasie.

Sonde bring mee dat ons God uit ons lewens wil uitrangeer, wil uitwis, in hoogmoed self God wil word. Hierdie neiging - om op God se troon te wil gaan sit - lê in ons diepste wese, in ons weefsel, in ons bloed. Die prediking van die wet sal daarom nie anders kán nie as om nie alleen die feit van die sonde nie, maar ook die verskriklike mag daarvan bloot te lê. En die prediker van die wet sal ook nie anders kán nie as om sélf in die daad van prediking uit te roep, of ten minste vanuit só 'n grondhouding te preek: mea culpa, mea maxima culpa (my skuld, my grootste skuld).

Die tragedie is egter dat ons ons van nature verset teen enige vorm van ontbloting van ons sondige self. Ons was eerder ons hande in onskuld - 'n ritueel waarmee ons helaas in Suid-Afrika ook nie onbekend is nie. Maar, dit moet ons verstaan: as ons by etiese prediking wil kom wat werklike veranderinge kan bewerkstellig, sal ons nie aan hierdie fundamentele stap van sondeverkondiging en skuldbelydenis kan verbygaan nie. Ons sal sonde nie net op die oppervlak mag preek nie, maar vanuit sy diepste teologiese agtergrond, en vanuit die wete dat elke woord wat ook oor óns, die predikers, se lippe kom, van nature onrein is, en dat ons woon onder 'n volk van wie elke woord onrein is (Jes. 6:5).

Ons roeping as predikers is om die situasie van die mens, en daarom ook van die Suid-Afrikaanse mens, voor God teologies tot op die been toe oop te klief - en te weet dat dié skerp swaard met sy twee snykante ons allereers stukkend sny. Ons kán nie bloot op die kansel volstaan met psigologiese of sosiologiese of eksistensiefilosofiese bestaansanalises van die mens nie hoe belangrik en onontbeerlik dít ook al mag wees - maar ons sal moet deurstoot na die bestaan van die mens voor God (coram Deo). Daarby sal ons in die prediking ook nie net die individuele mens in sy en haar innerlikreligieuse belewenisse in die oog moet kry nie, maar ook die mens in sy en haar verhouding tot die magte van die tyd en die institusies en strukture van die Suid-Afrikaanse samelewing, en die manifestasies van die sonde in al hierdie samehange.

Een ding waarteen ons as "kerkmense", en daarby ook nog as "amptelike predikers" verder sal moet waak, is om te dink dat die prediking van die wet net op die nie-gelowiges gerig moet wees. Nee, ook (veral!) gelowiges moet telkens in die lig van die wet na Christus toe gedryf word. Ons bele lewe is immers boetedoening - wat nie beteken dat ons die 
vreugde van vergifnis misloop nie, maar eerder dat ons vreugde diep en eg bly. Telkens mag ons ervaar, as geregverdigde en sondaar tegelyk (simul justus et peccator) dat ons ellendelingsroep: Ek, ellendige mens! Wie sal my van bierdie doodsbestaan verlos?, mag uitmond in: Aan God die dank! Hy doen dit deur Fesus Christus ons Here (Rom. 7:24,25).

Om jou skuld te bely, bly een van die hoopvolste dinge wat 'n mens kán doen. Dis immers 'n teken dat jy aan die einde van jouself gekom bet, en 'n glimmering van God se genade begin raaksien bet. Dis daarom ook'n basis waarop ons aan 'n werklik nuwe Suid-Afrika kan begin bou, waarop ons kan begin weef aan die tapisserie van 'n moreel gesonder samelewing. Om ons skuld teenoor God, maar ook eerlik teenoor mekaar te bely, en vir mekaar te bid - daarin lê ook ons morele gesondheid (vgl. Jak. 5:16). Daarin lê die kiem van ons hoop, lê die geboorte van 'n nuwe wêreld opgesluit...

Om skuld te bely, is nie 'n kreet in die niks in weg nie, maar dis 'n oproep aan 'n genadige adres, 'n smeking dat God sélf op grond van sy liefde weer nuut met ons sal begin: Kyrie, eleison! Ontferm U oor ons, Here, ontferm $U$ oor ons... (Psalm 123:3)

Kyrie, eleison!

Voordat die son oor Suid-Afrika sak...

Tweedens let ons op

\subsection{Die heiliging van die lewe}

Mense wat uit sonde verlos is, kan nie anders nie as om in dankbaarheid te antwoord. Dit maak hulle ánders, sigbaar as verloste en dankbare sondaars. Waarin hierdie andersheid presies lê, en veral hoe die werking daarvan verstaan moet word, is nie so 'n eenvoudige saak nie - 'n feit wat bewys word deur die talle (soms uiteenlopende) sieninge wat daar in die eeue van die kerk se geskiedenis rondom hierdie punt ontstaan het.

Christelike moraliteit (dankbaarheid) is uniek, dit wil sê duidelik te onderskei van 'n gewone burgerlike moraal, hoewel daar uiteraard bepaalde raakvlakke sal wees. Maar, waarin lê die uniekheid van die Christelike moraliteit dan?

$\mathrm{Na}$ my mening hierin: dit handel om die heiliging van die konkrete en alledaagse lewe, nie om 'n wegvlug na 'n "geestelike" vlak bó die lewe, of bloot ' $n$ introspektiewe intog na die innerlike toestande van die siel van die mens nie. Dit sou trouens as 'n soort reël neergelê kon word: wanneer daar op 'n moralistiese wyse op die innerlike toestand van die mens gekonsentreer word, vind daar 'n onttrekking uit die uiterlike, uit die konkrete, alledaagse werklikheid plaas (vir voorbeelde, vgl. verder 6.9).

Heiligmaking, in elk geval in die Gereformeerde sin van die woord, 
handel daarenteen om die heiliging van die totale lewe. Dit voer ons nie weg na die bo-natuurlike nie, maar stuur ons terug na die áárde toe, dié aarde wat deur die handelinge van God in die skepping en herskepping geheilig ís. Ja, God se genade verlos ons van die sonde, nie van die natuur (as goeie skepping van God), en daarom van die alledaagse nie. Dit bind ons eerder daaraan vas. "Voor God is daar geen lewe wat die lewe nie werd is nie. Vir God is die lewe self immers van groot waarde." (Bonhoeffer)

Dít leer die Here Jesus ons onder meer in die Ons Vader. Dat God selfs belangstel in ons daaglikse brood. Dat Hy ook die God van die sogenaamde "klein dingetjies" van ons lewens is. JH Sillevis Smitt skryf mooi:

"Jesus sê: Gaan gerus met jou bord kos na jou hemelse Vader toe. En daarmee bedoel die Heiland: Daar is niks waarmee jy nie by jou hemelse Vader mag kom nie. Vra maar vir God om skoene en klere. Vra Hom om 'n huis en meubels. Kom na Hom toe met jou werk en vakansie. Vertel Hom maar van jou beboefte aan liefde, jou verlange om te trou, jou bunkering om 'n kind. Wys vir Hom jou pyn en benoudheid. Wys vir Hom jou leë beursie en skrale spens. Praat met Hom oor hoë pryse en die moeilike werk wat jy nie kan baasraak nie...

"God is nie 'n God wat ver en vreemd is en daar hoog in sy bemel troon nie. God is 'n God van naby, wat in alles met ons meelewe en in al ons behoeftes wil voorsien. Daar is geen dors wat Hy nie wil les nie. Daar is geen honger wat Hy nie kan stil nie.

"Met bierdie bede lei Jesus vir God in ons huis in, in ons sitkamer; bring Hy God op ons kantoor, in die fabriek, op die land waar ons werk. Ons bet geen Sondagsgeloof nie. Ons God is: Heer van elke dag en van die alledaagse. Hy is nie net God van die kerk of van die binnekamer nie, maar God is ook in die straat, in die middel van die verkeer, in die kaserne en op die skip, in die huis en in die veld, in die fabriek en op die mark." (Onse Vader wat in die bemele is, Boekhandel De Jong (Edms.) Bpk. Johannesburg.)

Wie daagliks sy of haar brood uit God se hand ontvang, leer egter ook 'n gewisse openheid aan teenoor ander met broodgebrek. 'n Mens kan beswaarlik sê: gee ons vandag ons daaglikse brood, en tog snoep die brood op jou eie tafel hou. Omdat ons besittings nie ons eie is nie, en omdat ons weet dat die Vader vir ons sal sorg, moet ons hand oopgaan om te gee vir ander. Die brood op ons bord "behoort" ook aan ons buurman. Wie bid: "Gee ons ...." moet inderdaad self ook aan ander gee.

Martin Luther het gesê: Ons is diewe en rowers as ons só vasklou aan ons eie brood dat ons vir die bedelaar sê: ek het gewerk vir die brood in my buis. Sorg jy maar vir jouself. As ek hierdie behoeftige nie voed nie, word my goed gesteelde en 
geroofde goed, ook wanneer dit nie geroof en gesteel is nie. Daardeur word ek 'n dief vanweë my eie goed, deurdat ek niemand daarmee dien nie. Daar is twee soorte rowers: bulle wat steel... en bulle wat bulle eie goed soos diewe gebruik.

Die gebed om brood het inderdaad 'n geweldige dringendheid in ons wêreld met sy hongersnood en sy miljoene ondervoede mense en veral kinders. Dit raak ons ook in hierdie land met sy kroniese armoede. Ons kan beswaarlik die Ons Vader onaangeraak bid as óns tafels kreun onder die lading van ons lekkernye, terwyl miljoene magies kreun om 'n krummeltjie. Daarom moet die dinge wat ons "het", wat ons van God ontvang het, ons ook maklik uit die hand gaan. Daarom moet ons vir ons 'n sekere soberheid aanleer, 'n soberheid wat ten minste bereid is om die luukse - en as dit nodig is - meer prys te gee. Dis juis hierdie soberheid van die gebed wat ons tref: dit gaan oor die broodporsie vir vandag, niks meer of minder as dit nie. Wat God meer gee as dit, is rede tot dankbaarbeid teenoor Hom en diensbaarbeid aan ander.

Nou is dit juis hierdie dankbaarheid en diensbaarheid wat so teen ons sondige grein ingaan en wat ons maar moeilik kan sluk. Ons kou God se brood lustig voort, sonder 'n blik na bo of 'n gedagte aan ander. Dis elke mens vir hom - en haarself! Ons het voorwaar genade nodig om hierdie sondige ingekeerdheid om te keer, om ons uit te dop tot dankbaarheid en diensbaarheid. Ons het die Heilige Gees nodig om ons 'n nuwe styl te leer, om ons verstokte harte en ons krampagtige vingers oop te beur. Ons het die Heilige Gees nodig om te sê : Abba,Vader!, én om te sê: Medemens, broer, suster! Hierdie bede wat feitlik in die middel van die Ons Vadergebed staan, sny oorgeestelikheid by die wortel af. Hierdie gebed leer ons onder meer dat 'n onmenslike Christen 'n onding en 'n teenstrydigheid is; dat God nie van ons engele wil mak nie, maar mense, ware mense - vir ander mense! (Aangepas uit: Johan Cilliers: Meer as mossies)

Daarom kry 'n mens ook nie "goeie mense" binne in die kerk, en "slegte mense" buite die kerk nie. Die "wêreld daarbuite" is nie sondermeer boos, en die "kinders van die Here" hier binne nie sondeloos nie. Trouens, die enigste verskil tussen die kerk en die wêreld is dat die kerk van haar eie goddeloosheid weet, en die wêreld nie (Barth). Op geen manier mag die kerk haar bo die wêreld verhef of uit die wêreld probeer wegvlug nie.

Dit was die grondfout van die Fariseërs. Binne-in die wet staan hulle teen die genade, en "bo" die res van die sondaars. Hulle wil gesien word 'n karikatuur van die feit dat hulle as ligte in die donker moes skyn. Fariseïsme is trouens niks anders nie as 'n maskerade teen God en sy genade, omdat die wet uit sy verbande met God en sy genade gelig word, en nou as 'n genadelose roede teen ander wat "nie op standaard is nie", ingespan word. Fariseïsme is nie 'n outydse verskynsel nie. Inteendeel, dis springlewendig - veral in die kerk. Dis egter soveel gevaarliker as ander 
"bose" dwalinge, juis omdat dit veel van die genade van God weet, maar dit dan misverstaan as 'n blote fase wat (algaande) agter jou lê. Omdat dit reken: ons het die genade ontvang, maar nou hang dit verder van óns af. Waarlik, om anders te wil wees op grond hiervan, is ligjare verwyder van die Bybelse visie op die "andersheid" van die kerk...

Waarin lê die "andersheid" van die kerk? Daar sit altyd 'n soort spanning in. Dit blyk byvoorbeeld wanneer Paulus skryf: Aangesien julle saam met Christus uit die dood opgewek is, moet julle strewe na die dinge wat daarbo is, waar Hy aan die regterhand van God sit. Rig julle gedagtes op die dinge wat daarbo is, nie op die dinge wat op die aarde is nie... $(3: 1,2)$

Hierdie uitspraak is nie alleen 'n treffende voorbeeld van Paulus se denkpatroon nie, maar van die struktuur van die evangelie self. Die woordjie aangesien verwys na dit wat God reeds gedoen het, na afgehandelde heilsfeite, na die groot dade van God in Christus - ter wille van ons. Paulus maak hier, soos op talle ander plekke in sy briewe, 'n lys van dié dade - nie vir selfkontrole nie, maar vir danksegging, en toewyding. Byvoorbeeld só:

Fulle bet gesterwe, en julle lewe is saam met Christus verborge in God. Fulle is saam met Christus uit die dood opgewek (Kol. 3:1,3). Fulle bet saam met Christus 'n plek in die bemel (Efes.2:6). Wanneer Christus, wat julle lewe is, by sy wederkoms verskyn, sal julle ook saam met Hom verskyn en in sy beerlikbeid deel (Kol. 3:4). Fulle is alréds verbeerlik (Rom. 8:30).

Dit staan vas! Dis geskiedenis! Verlede tydsvorm! Dáárom... strewe en rig na bo! 'n Mens kan die spanning in die teks aanvoel, 'n spanning wat ook van begin tot einde deel is van ons geloofslewens, 'n spanning wat nou nog saamgaan met ons saligheid. Sommige noem dit die spanning tussen die reeds en die nog nie. Ons het reeds alles... en tog ook nog nie! Ander praat van die spanning van gelowiges tussen die tye van die eerste en tweede koms van Jesus. Karl Barth sê êrens: dis nie die spanning van mense wat nog alles moet soek nie, maar van mense wat alles gevind het - en daarom nou alles moet soek! Paulus beskryf dit self treffend op 'n ander plek: ek span my in om dit alles myne te maak omdat Christus Jesus my reeds Syne gemaak het (Fil. 3:12). Ek gryp daarna, omdat ek self gegryp is!

Hierdie spanning mag nooit, in elk geval in hierdie bedeling, ontlont word nie. Die dwaalleraars in Kolosse het dit probeer doen deur 'n oorbeklemtoning van aardse, wettiese reëls. 'n Mens kan dit egter ook verkeerdelik na die ander kant toe probeer doen, en so eintlik 'n karikatuur daarvan maak. Jy kan geesteliker as die evangelie probeer wees - deur die aardse, dit wil sê die wêreld te vermy. Soos die kerkvader wat vir hom 'n huisie op 'n houtstellasie laat oprig het, etlike meters bo die grond. Daar het hy vir baie jare gewoon, sy lewensmiddele na hom toe laat opkatrol. Hy 
het niemand gesien nie, en sorg gedra dat niemand hom ooit sien nie. Met sy kop in die wolke, los van hierdie aarde af, het hy gemeen om heiliger te word as ander aardlinge.

Het hy? Ek weet nie. Wat ek wel weet, is dat die evangelie nie van my 'n wolkbewoner of 'n engel op 'n paal maak nie. Die spanning van die saligheid sit my voete vas op hierdie aarde. Dis immers God se aarde. Is hierdie aarde nie ook 'n ruimte waarbinne God werk nie? En, is ons eindbestemming nie juis ook die nuwe aarde nie? Nuut, maar nog aarde! Ons moet - in hemelsnaam - tog ook bevry word van ons "geestelikheid". Dis egter die moeilikste ding waarvan ons bevry kán word...

Wanneer Paulus sê: strewe na die dinge wat daarbo is, rig julle gedagtes op die dinge wat daarbo is, bedoel hy kennelik nie wêreldvermyding nie. Trouens, kort daarna maak Paulus wéér 'n lysie, begin hy uitwy oor die mees konkrete, kan ek maar sê mees aardse verhoudings waarbinne ons staan. Op sy lysie staan die verhouding tussen man en vrou, ouers en kinders, slawe en eienaars (3:18-4:1). Want die evangelie het alles te make met ons alledaagse en ons sogenaamde gewone, met die politiek en die etiek en die ekonomie. Dit het alles te make met hierdie aarde en die mense op hierdie aarde. Die evangelie het te make met dit wat mooi is, en wat jy maar mag geniet. Trouens, as jy nie vandag iets geniét het nie, was jy nog nie binne God se wil nie (volgens die Rabbi Akiba).

Die verskil tussen Paulus se lysie van oproepe en dié van die dwaalleraars is die feit dat dit presies omgekeer is: Hulle wou die hemel bereik deur op die aarde te konsentreer; die evangelie herwin die aarde deur op die hemel te konsentreer. Die evangelie laat ons eers 'n draai in die hemel maak, maar sodat ons kan terugkeer aarde toe! Dit is wat Christene is: hemelsoekers op die aarde, vir die aarde. Hemelstrewers, hemelgerigtes - maar met die oog óók voluit op die aarde, omdat dit God se aarde is.

Jesus word immers 'n mens, nie 'n engel of 'n gees nie. Hy verlos ons ook om mense te word, ware mense, en dus Christene. Ons moet tog nie geesteliker as Jesus probeer wees nie. Met sy menswording onderstreep Hy die waarde van menswees. Met sy koms na die aarde bevestig Hy die waarde van die aarde. Hoe skoon die aarde, dit het veel waarde! Immers, Jesus bring die hemel aarde toe. Daarom is ons aardlinge wat eintlik hemelinge is, en hemelinge wat eintlik aardlinge is. Aardse hemelinge, en hemelse aardlinge. Dis óns.

Dis die spanning van ons saligheid. (Aangepas uit: Johan Cilliers: In die greep van God)

Dit kan nie genoeg benadruk word nie: die evangelie maak ons nie los van die "wêreldsgoed" nie, maar vul eerder die "wêreldsgoed" met 'n nuwe betekenis. "Die bediende wat haar kombuis vee, doen die wil van God net soveel soos 'n monnik wat bid - nie omdat sy 'n Christelike lied sing terwyl sy vee nie, 
maar omdat God lief is vir skoon vloere. Die Christenskoenmaker doen sy Christenplig nie deur klein kruisies op sy skoene te sit nie, maar deurdat by goeie skoene maak, want God stel belang in goeie vakmanskap."(Luther) Waarlik, ons moet waak daarteen om óf ons geloof te wil verkerklik, óf ons roeping te wil klerikaliseer - so asof geloof net binne die mure van die kerk, en ons roeping net "amptelik" kan wees. Die keuse mag nooit wees of jy aangaan met jou alledaagse werk, en of jy "voltyds vir die Here gaan werk" nie. Ons word immers geroep om in álles wat ons doen, die Here te eer (1 Kor. 10:31).

Die goeie werke van die geloof is daarom ook nie (noodwendig) buitengewone, spektakulêre werke nie, maar dit wat in die geloof vanselfsprekend is, omdat dit in die geloof moontlik is. Sulke goeie werke hoef nie eers deur mense gesien te word nie, maar dis vir God aanneemlik en aan Hom bekend. Om heilig te lewe, is om gewoon (!) te doen wat jou hand vind om te doen. $\mathrm{Al}$ is dit skynbaar min en klein.

Ons word geroep om Jesus in die konkrete bestaan van elke dag na te volg. Hierdie navolging van Christus is egter nie gelykstaande aan 'n blote nabootsing (imitatio) van Christus nie. Ons kán gewoon nie die natuurlike lewe van Christus dupliseer nie, kán Hom nie in die uiterlike dinge namaak nie, maar kán ook nie die voorbeeld van sy "innerlike" vervulling van die wet op ons beurt vervul nie. Jesus se lewe is nie slegs 'n illustrasie van die wet, en sy vervulling daarvan ons sedelike ideaal nie. Om Christus in die alledaagse na te volg, is om in gemeenskap met Hom, deur sy Gees, in die konkrete werklikbeid te leef.

Dis dus nie bloot die najaag van 'n ideaal daar êrens, ver voor nie, maar 'n lewenswyse, gefundeer in die teenwoordigheid van die lewende Christus, hier en nou. Dis 'n lewe in gehoorsaamheid, uit genade - tot in die alledaagse besonderhede. Om Christus na te volg, dit wil sê in sy voetspore te loop, bestaan nie uit die toepassing van 'n aantal op-jouselfgerigte religieuse tegnieke nie, maar daarin dat jy die alledaagse in die oë kyk, en leef uit die teenwoordigheid van Christus in hierdie alledaagse. Sodat God in álle dinge geëer mag word.

In die heiliging van die lewe en die navolging van Christus gaan dit egter nie net om die klein dinge nie, maar ook oor die groter samehange van die samelewing. Elke duimbreedte van die lewe en die werklikheid behoort immers aan Christus. In die lig van Christus se opstanding, en die uitstorting van sy Gees, word die gebod vir die lewe, die héle lewe, radikaal en universeel. Navolgers van Christus kán nie, mág daarom nie die verval van die samelewing vir lief neem nie. Inteendeel, hulle wat die verlossing uit die sonde ervaar het, word in die gewete aangespreek oor die ellende waarin hulle medemense verkeer, sowel as die ellende en boosheid wat daar dikwels in die strukture van die samelewing skuil. Wie die evangelie 
gesmaak het, kán nie anders nie as om in skuldverbondenheid met die mensdom te worstel met etiese sake soos armoede en ekologie, vigs en geweld, kortom, met álles wat hierdie aarde, en in ons geval, Suid-Afrika, bedreig.

Kom ons vra weer: Waarom moet ons in die prediking ook met etiese sake omgaan? Omdat die evangelie ons leer dat God die aarde liefhet. Hierin lê die somtotaal en sin van al ons etiese handelinge. As ons vra hoe ons eties in die Suid-Afrikaanse situasie moet preek, lui die antwoord kortweg: deur die liefdesgebod te preek. Uiteindelik is dit nie ' $n$ bumanistiese of sosiale program wat Suid-Afrika van ontmensliking gaan red nie, maar die verkondiging en die toepassing van die liefdesgebod deur die kerk in Suid-Afrika.

Dit mag op die oog af te eenvoudig klink. Dit ís ook eenvoudig. Die gebod vir hierdie uur in Suid-Afrika is werklik nie ingewikkeld nie. Inteendeel, dis glashelder. Dis om uit die mond van die Here self te hoor: Gaan maak jy ook so (Luk. 10:37). Maar, ons het mos hierdie neiging om, veral in ons godsdiens, dit wat eenvoudig is in 'n ingewikkelde teorie te verander, dit in 'n vraag te omskep waaragter ons gerieflikheidshalwe vir die opdrag tot gehoorsaamheid kan skuil: En wie is my naaste (Luk. 10:29)?

Jesus sien dwarsdeur dié vraag. Hy ontmasker dit as 'n vernuftige ontvlugtingsmeganisme, 'n ontsnapping in abstraksie en teoretisering. Robert McAfee Brown skryf met 'n goeie dosis humor en selfkennis hieroor:

"Deur die vraag só te stel, bring die wetgeleerde die gesprek terug in 'n (vir hom) veilige gebied. Nou hoef hy nie 'n naaste te wees nie. Hy moet net die wese daarvan definieër. Dít kan hy op 'n briljante wyse doen, sonder dat sy eie lewe daarmee onder die vergrootglas kom. Dalk het hy só geredeneer: 'As dié gesprek met Jesus vrugbaar is, kan ek 'n simposium reël met die tema: Die konsep van naasteliefde. Op die simposium kan ons dan 'n werklik omvattende en begronde definisie van naasteliefde formuleer. 'n Aantal referente kan referate lewer soos: Die Stoïsynse begrip van naasteliefde, of: Naasteliefde in resente Midde-Oosterse fiksie, of: Die kulturele implikasies van naasteliefde met die oog op die verbetering van handelsbande met Griekeland, of: Naasteliefde - 'n vroulike perspektief (natuurlik deur 'n man gelewer om die nodige objektiwiteit te verseker!) Dalk kan ons een van die pas afgestudeerde doktorandi vra om die nuutste empiriese gegewens onder ons aandag te bring, met 'n onderwerp soos: Naasteliefde soos gesien deur lede van die slaweklas. 'n Reeks onderhoude gevoer op die Aleksandrynse slawemark ten einde kontemporêre data vir 'n satisfaksie-dissatisfaksie-skaal te versamel. Ek is natuurlik heeltemal bereid om redakteur te wees as 'n uitgewer dié referate wil publiseer!"' (Vry vertaal uit: McAfee Brown, R. 1984:107). 
Nee, die evangelie is helder hieroor: Wees jy'n naaste vir ander...

Die kerk bestáán trouens ter wille van die naaste. Daarom mág ons nie in ons "heiligmaking" só bly draai soos 'n mot om die kers van ons eie, innerlike belewenisse, só bly wentel om die lig van ons vermoëns of die verdriet van ons tekortkominge, dat ons gewoon nie tyd of energie oor het om ons medemense lief te hê, en só die wet van God te vervul nie. Pront gesê: mag ons nie so besig met onsself, so lief vir onsself raak, dat ons nie meer ons medemense kan liefhê nie...

Dit het weer tyd geraak vir 'n preekanalitiese toer, 'n toer wat tragies illustreer dat ons juis bogenoemde uitgangspunte, ook in Suid-Afrika, nog nie wérklik in ons prediking verstaan het nie...

\title{
5.9 Preekvoorbeelde van 'n mislukte (moralistiese) visie op die gemeente
}

\author{
Daar is nie een wat regverdig is nie, \\ selfs nie een nie, \\ daar is nie een wat verstandig is nie; \\ daar is nie een \\ wat na die wil van God \\ vra nie. (Rom. 3:10,11)
}

Só beskrywe die Skrif die mens in sy en haar totale verlorenheid voor God, 'n beskrywing wat heelwaarskynlik deur die meerderheid predikers teoreties beaam sal word. Dit beteken ongelukkig egter nie dat dit noodwendig in die praktyk van die prediking as 'n veronderstelling funksioneer nie. Inteendeel, die verskeidenheid vorme van semi-pelagianisme en selfs volbloed Pelagianisme of Arminianisme (leringe wat almal, in mindere of meerdere mate, aanvaar dat die mens tog die vermoë het om mee te werk in die uiteindelike verkryging van sy of haar saligheid, en dus nie totaal deur die sonde verdorwe is nie) wat in die prediking aan die orde is, is eenvoudig verstommend. Die redes hiervoor kan uiteenlopend van aard wees, kan ook 'n komplekse samestelling van verskeie faktore wees. Een daarvan is, soos ons reeds gesien het, die verandering van Bybels-teologiese uitsprake in antropologiese uitsprake (vgl. 3.7.4). Wanneer die werklike handelinge van God, waarvan die Bybelteks getuig, nie meer in die hede uitgespreek word nie, is dit byna vanselfsprekend dat oorgegaan sal word tot die verkondiging van allerlei imperatiewe wat die handelinge van mense verlang. Hoogstens kan die heilsindikatief nog ten opsigte van God se handelinge in die Bybelteks volgehou word, maar sodra die huidige gemeente in die oog kom, word hulle die subjek, die bron van hierdie heilshande- 
linge. By implikasie sê sulke preke: God het wel in die historiese indikatief van die Bybelteks gehandel, maar daarmee is sy handelinge afgehandel. Nou kom die mens aan die beurt. Nou word alles op sy of haar rekening geplaas. Die skema indikatief-imperatief word dan gestereotipeer as gelykstaande aan die volgorde: God se handelinge - ons handelinge. Dit is 'n algemene teologiese kortsluiting, 'n wettiese vergissing wat hom al in ontelbare preke gewreek het. Ten diepste vloei hierdie kortsluiting voort uit 'n twyfelagtige siening van wat sonde is.

\subsubsection{SONDE? SKULdBELYDENIS?}

Wel word daar heel dikwels in wettiese preke oor die sonde van die mens gepraat - én breedvoerig! Dit geskied op verskillende vlakke, waarvan ek drie noem. Eerstens is daar 'n neiging om die werklikheid van eie sonde en skuld te verbloem deur dit op iemand of iets anders se rekening te plaas. Sonde en skuld is daar wel, maar dis nie ons sonde en skuld nie. Tweedens word aanvaar dat die mens ' $n$ probleem het, moontlik siek is, maar nie dat hy of sy dood is as gevolg van hulle oortredings en sondes nie (Efes. 2:1). Hier word dan op simptome gewys, sonder dat die dieperliggende gronde van die sonde werklik in die oë gekyk word. Derdens seëvier die uitgangspunt dat die mens in staat is om self 'n uitweg uit die sonde te vind. Die sonde word onskadelik gestel en die moontlikheid vir die opheffing daarvan in die potensiaal van die religieuse mens begrond.

\subsubsection{Ontkenning}

As illustrasie van die eerste vlak van sondeverkondiging - wat eintlik 'n ontkenning daarvan is - haal ek 'n enkele sin uit 'n preek oor 1 Korintiërs 6:12-20 aan:

"The Christians in the city of Corinth, like us today, were living in a society where immorality was not considered wrong. And, like us, they were also being influenced by the standards that prevailed in the society of which they were a part."

As sodanig gesien bevat dié uitspraak natuurlik elemente van die waarheid. Die samelewing - konteks - beïnvloed ons almal wel deeglik. Die konteks waarbinne hierdie uitspraak funksioneer, bring egter mee dat dit 'n bepaalde betekenis verkry, naamlik om die tafel te berei vir die voorskrifte wat volg. Die grootste gedeelte van die preek word dan verder daaraan gewy om die reëls uit te spel waaraan jongmense hulle moet hou om hierdie bedreiging van buite teen te staan, maar nêrens word die hoorders 
geskets as mense wat vanweë hulle sonde nie in stáát is om weerstand te bied nie, en daarom die verlossende werk van die evangelie nodig het. Die struktuur van die preek draai op twee skarniere, naamlik enersyds die eksterne bedreiging en andersyds die veronderstelde vermoë van die hoorders om die bedreiging die hoof te bied. Ten einde die eerste skarnier te laat funksioneer, maak die prediker gebruik van die retoriese tegniek wat deur linguiste passivering en/of nominalisering genoem word (vgl. Kress en Hodge 1979:72 e.v.). Wanneer sulke taalkundige transformasies in tekste voorkom is dit gewoonlik 'n aanduiding dat die skrywer, of in hierdie geval, prediker, die handeling van sekere hoofagente wil verbloem en die aandag verplaas na ander, eksterne agente - 'n tegniek wat dikwels in diens van ideologievorming ingespan word. Die effek is om die gevoel van aktiwiteit af te stomp, om aandadigheid aan handelinge te elimineer en prosesse in objekte te transformeer. Die oorsaak van die skuld lê dan elders, en die noodsaak van 'n radikale verlossing verval.

\subsubsection{Vervlakking}

Wat die tweede vlak van sondeverkondiging betref, wys ek op 'n preek oor die bekende gelykenis van die verlore seun, waarin die prediker met reg die lig ook, en veral, op die ouer broer laat val (Luk.15:25-32). Die probleem van dié broer formuleer die prediker só:

"...the tragedy of the older brother was that he had a great father but be bimself did not become great."

Dit gee 'n eerste aanduiding van die hermeneutiese doelwit - om die hoorders daartoe te lei dat hulle ook, soos die ouer broer, "great" kan word. Dit is 'n statuur-aanduiding. Die preek gaan voort en omskryf die probleem van die ouer broer verder:

"The younger brother is sunken into iniquity but the older brother is weary of well-doing and he's just lost the freshness of his Christian life. This older brother has somehow found that his joy as a Christian has waned. But our Lord acknowledges that behind all this there is a basic sincerity that has kept this man flagging on, on the farm, throughout his life."

Die ouer broer (wat 'n beeld is van die Fariseërs) word die prototipe van 'n Christen wat nie (meer) op standaard is nie. Sy enigste sonde is sy laksheid. Inherent is hy 'n goeie mens - nie volmak nie, gee die prediker verder aan toe ("far from perfect") - maar met 'n "basic sincerity". Hy word selfs voorgestel as een wat "mature in the church" is. Hy is net 
"weary and jaded and tired". Dié probleemstelling word opgevolg met die gebruiklike lys van dinge wat die Here bereid is om te doen om die probleem op te los (“...He who would so willingly give...”), maar wat nog nie kan gebeur voordat die mens met sy basiese goedheid sy moegheid afgeskud en teruggekeer het uit "the far country of disillusionment and weariness and meaninglessness" nie. So 'n mens het nie werklik verlossing nodig nie. Met sy eie handelinge stel hy of sy alles weer in orde, word dit wat aan die Vader behoort weer sy of haar eiendom. Aan die einde van die diens bid die prediker:

"Thank You Father, that when our hearts are broken and contrite...everything that you bave is ours."

Die Bybelteks sê dit juis nié. Die ouer broer se hart was - so ver ons weet - nié gebroke nie. Maar belangriker: die gebrokenheid van sy hart was ook nié 'n voorwaarde voordat die Vader kon sê : alles wat $\mathrm{Pa}$ het, is ook joune nie (Luk. 15:31).

\subsubsection{Opheffing}

Die derde vlak waarop sondeverkondiging dikwels plaasvind, blyk treffend uit 'n preek oor Efesiërs 4:11-16. Die prediker begin met die skets van 'n toneel wat hom somtyds in die natuur afspeel: 'n arend se "aangebore" natuur is om vry te wees, dis 'n voël "wat met sy sierlike vlerke kan sweef in die lug." Sit jy hom egter in 'n hok, leer hy ook 'n "ander natuur" aan, naamlik dié wat pas by die gevangenskap. Indien die hok van die arend byvoorbeeld oopgelaat sou word, gebeur dit meermale dat hy nie wegvlieg nie, maar in sy gevangenskap bly sit. Sy "ander" natuur (hier 'n beeld van ons sondige natuur) verhoed hom om ooreenkomstig sy "aangebore" natuur te leef. Die beeld is teologies verdag. Ons aangebore natuur is mos ons sondige natuur, nie waar nie? Ons is "in sonde ontvang en gebore"! Ons het nie 'n natuurlike staat waarheen ons moet of kan terugkeer sodat ons weer "net normaal" kan wees nie. Weliswaar sê die prediker: "ons is gebore as mense en ons het 'n sondige natuur...", maar blykbaar is die bedoeling dat ons hierdie sondige, "ander" natuur moet afskud en weer word wat ons "aangebore" natuur is. Hoe doen ons dit? Presies soos die arend dit gedoen het! -

"Dit het lank geneem voordat daar eendag ander arende oor hierdie buis gevlieg het en toe hierdie arend die kreet hoor van die arende wat bo hom vlieg, toe besef by maar dis mos soos ek behoort te wees. En daar het die arend eers uitgestyg, kan ons sê, uit sy eie gevangenis uit." 
Wel gee die prediker toe dat dit nie 'n maklike proses was nie. Dit het die arend lank geneem om weer sy vryheid aan te leer. Maar die punt is: dis uiteindelik hy self wat hom uit sy gevangenis bevry. "Ons is nie anders nie", sê die prediker. Ons het 'n sondige natuur, maar ons het die vermoë om terug te keer na ons oorspronge, ons "aangebore" natuur, wat in wese ongeskonde is. Hierdie terugkeerproses word soos volg beskryf:

"Maar as ons by die Here uitgekom het, dan het iets wonderlik gebeur. Hy bet ons nuutgemaak. Maar weet $u$, dan moet ons dikwels nog leer om uit bierdie natuurlike bok van ons uit te breek en te begin word wat ons is in die Here."

Die agent wat die hok se tralies breek, bly steeds die mens. Die voorwaardelike konstruksie as ons...dan beteken tog: iets wonderliks kan nie gebeur voordat die mens dit laat gebeur nie. Dis die mens wat (vanuit die hok) by die Here moet uitkom, wat moet leer om dit te doen, maar ook nie eers altyd nie - net dikwels. Dis daarom heel logies dat die preek verder swaar gelaai is met aankondigings van wat die Here alles wil doen en wat die hoorders alles moet doen - ten einde 'n volgroeide mens te wees, so volmaak en volwasse soos Christus (Efes. 4:13). Die ontspoorde sondebegrip (hamartologie) aan die begin van die preek, lei tot die verlies van die verlossingsbegrip (soteriologie) in die res van die preek.

\subsubsection{DIE VEREDELING VAN DIE RELIGIEUSE MENS}

In preke van hierdie aard is Christus inderdaad nie werklik nodig nie. In Sy plek kom daar heilige, voorbeeldige karakters en morele norme waaraan mense hulleself moet meet, en waarheen hulle hulleself moet opwerk. Die evangelie self word misverstaan as 'n oproep tot morele verbetering 'n verbetering wat mense self, uit die reserwes van hulle religieuse potensiaal, kan aanbring. Dikwels is die norme wat voorgehou word, en waaraan mense moet konformeer, niks anders as die heersende, burgerlike moraal, of as dié verval het, die versugtinge en voorstellinge van só 'n moraal nie. Dan is die mikpunt van die prediking bloot dat mense ordentlike burgers van die samelewing sal word, mense met 'n basiese en gemiddelde opregtheid. Ons sou kon sê: wettiese preke het ten doel om die reeds religieuse mens te help om meer religieus te word, om by te dra tot sy of haar veredeling. Dit veronderstel foutiewelik dat mense in staat is om self die wet van God na te kom, indien hulle net die werklike wil daartoe het en net hard genoeg probeer. Die waarheid is egter dat ons nie kán nie, selfs al wíl ons! Wat ons in Suid-Afrika nodig het, is nie bloot gawe, goeie burgers nie - hoewel dít sekerlik nie sleg is nie. Die feit is net dat hierdie gawe, goeie 
mense op die korter of langer duur nie so gaan bly nie. Daarvoor is ons sonde te diep gewortel. En veral: daarvoor het ons nie morele opleidingsprogramme nodig nie, maar die evangelie.

Die miskenning van die realiteit van die sonde vind meestal nie doelbewus plaas nie, eerder subtiel en onbewus. Dit glip so maklik in ons taal in. Verlê die wissels net so effens - maar neem dan die troos van die evangelie weg. Wanneer 'n prediker byvoorbeeld na aanleiding van die gelykenis van die goue muntstukke (Matt. 25:14-30) sê: "Soos wat Hy gekom bet om mense te dien deur bulle te belp om bulle verbouding met God reg te stel en om bevry van die mag van die sonde te lewe, moet ook bulle diensbaar aan hulle medemense wees." is dit die eeue-oue verskynsel van semi-pelagianisme wat maar weer sy kop uitsteek. Jesus word 'n bemagtigingsprinsipe vir Christelike aktiwiteit, Een wat ons moet help om (verder) sélf uit die mag van die sonde bevry te word, sélf verlos te word (in die regte verhouding met God te kom) en daarom sélf diensbaar aan die medemense te word.

Dit wémel inderdaad van sulke voorbeelde in die preke. Wanneer 'n prediker in 'n meditasie oor 1 Kor. 13 verklaar: "Ons is skepsels van liefde, ons basiese geaardheid is 'n liefdevolle geaardheid", is dit 'n poging om op ons oorspronklike skeppingskonstitusie te wys. Die fatale fout wat hy dan egter maak, is om op grond hiervan - asof daar geen sondeval plaasgevind het nie! - die hoorders op te roep om ooreenkomstig hierdie skeppingskonstitusie te leef. 1 Kor. 13 word in so 'n geval 'n wet wat my moet terugdryf na my basiese geaardheid, nie 'n gebod waaruit ek as verloste met dankbaarheid mag leef nie. Daarom is sinne soos die volgende volkome logies: "Elke dag moet ek die vorige tyd teenoor my Christelike roeping opweeg, veral ten opsigte van die roeping van liefde, en my lewe verbeter volgens fesus se wil. Dit is nie maklik nie. Kom ons probeer vanaand om hierdie bekering in ons lewens te begin sodat môre 'n mooier dag sal kan wees by die buis en by die werk." Vernuwing word verander in "verbetering", en God se genade in "kom ons probeer". Dis óns wat die bekering in ons lewens begin. Nie God nie.

Die slotsin van 'n meditasie wat, ironies genoeg, juis na aanleiding van Josua 7 op die erns van die sonde wil wys, klink só: "Raak ontslae van die veroorsakende faktore wat jou laat val, en laat die Heilige Gees toe om sy vinger op daardie plek te lê wat krisis veroorsaak. Maak daardie deel dood in jou lewe kruisig dit." In hierdie sinskonstruksie is die een wat die inisiatief neem en behou, niemand anders as die méns nie - 'n feit wat deurlopend in die preek bevestig word. Dis die mens wat álles doen, wat die Heilige Gees toelaat, wat ontslae raak van die sonde... en dit uiteindelik kruisig. Die verlossingswerk van Christus, die Gekruisigde, is prinsipieel nie nodig nie. 


\subsubsection{DIE BEWEGING NA DIE INTRA-PSIGIESE}

'n Opvalllende tendens by preke met 'n antroposentriese inslag, is die beweging weg van die Bybelteks af na die innerlike van die mens. Dikwels word die innerlike gemoedstoestand van Bybelse figure geskets - meestal met 'n goeie kwota teksinleg! - met die spesifieke doelwit om die hoorders tot 'n soortgelyke gemoedstoestand op te roep, of, indien die Bybelse figuur as 'n negatiewe voorbeeld funksioneer, om die hoorders van sodanige geestesinstelling af te skrik. Wat ookal die geval, die blikpunt van die preek bly binne die ruimtes van die intra-psigiese vassteek.

Opvallend is dit in 'n preek oor Handelinge 1:8 en Romeine 1:8-17 hoe gereeld die prediker afdaal na die dieptes van die menslike psige. Hy beoefen trouens wat ons 'n teologie van die diepe piëteit sou kon noem. Alles is diep...of dieper - byna soos in die Middeleeuse mistisisme. So hoor ons telkens van "die diepe indruk" waaronder Paulus of die prediker of die hoorders gekom het of moet kom, van hulle roepe tot God "uit die hart uit", hulle gereedheid in die "gees" en in "gesindheid", hulle "diepste gevoelens" en "begeertes", ensovoorts. Dat die prediker inderdaad van sy hoorders verlang om die innerlike gemoedstoestand van Paulus na te maak, blyk uit sinne soos die volgende:

"En dan sien ons Paulus was gereed gewees in sy hart. Sy hart was gereed. In sy hart was daar 'n diepe begeerte....' $n$ diepe verlange. Dit moet gebeur."

Helaas, ook diepte-psigologie kan 'n selfpreparaat vir die verlossing word, 'n wyse waarop ek self sielehigiëne moet toepas. Hoe beter die higiëne, hoe sekerder die verlossing. En omgekeerd...

Die tragedie van wettiese prediking is dat dit dikwels dinge wat as sodanig nie verkeerd is nie, neem en dit in diens van die selfregverdiging inspan. So kan geloof byvoorbeeld omskep word in 'n mensewerk, of die "stilword" van die mens voor God, of etiese aktiwiteite waartoe mense opgeroep word. Dikwels is dit klein, skynbaar onskuldige woordjies wat God se handelinge en ons handelinge op 'n wettiese wyse uitmekaarhaal, wat dit wat slegs in die dinamiese relasie tussen God en mens te verstaan is, substantiveer en tot eie besit maak.

\subsubsection{WETTISISME EN WERKLIKHEID}

Waar God met die mens in 'n verhouding tree, word die werklikheid waarbinne die mens leef, werklik verander - omdat God dit werklik verander het en steeds daarmee besig is, ook deur dié mens heen met wie Hy in 'n verhouding getree het. In dié verband is daar 'n merkwaardige oor- 
eenkoms tussen feitlik alle wettiese prediking te bespeur, naamlik die konsekwente verlies van werklikheid, in dié sin dat dit verby die werklikheid praat. Dit is eintlik logies: wettiese preke mag op die oog af op die hede en die werklikheid gerig wees, maar tog is dit ontrou daaraan, omdat daar geen werklike veranderende kragte daarin werksaam is nie. In wettiese preke werk God nie. Daarom mis dit die werklikheid, is dit onwerklik, dit wil sê nie-kontekstueel.

Maar, soos ons nou al meermale in hierdie hoofstuk beklemtoon het: met die werklikheidsgetrouheid van die prediking staan of val egter baie, inderdaad alles. Hierin lê die konkreetheid, die aktualiteit van die prediking opgesluit: dat dit die werksaamheid van God, hier en nou uitspreek. Wettiese preke verskuif sy handelinge óf terug na die verlede óf vooruit na die toekoms. Dit spreek nie die faktiese mens in sy en haar sosiale, ekonomiese, politieke, kerklike, kulturele en geslagtelike kontekste met die teenwoordigheid van God aan nie, maar bly abstrak en tydloos, dit wil sê wêreldvreemd. Dit bly veral ook evangelievreemd, want die evangelie het altyd 'n spesifieke adres, moment, kairos waarin dit ter sprake kom en waarin dit veranderend werksaam is. Hierop het die Reformatore juis sterk klem gelê, naamlik dat die doel van die prediking ons verandering is. Hierdie verandering geskied op grond van die verlossingsdaad van God in Christus en deur die toepassing van die heilswerklikheid deur die Heilige Gees in en aan mense. Dis dus op geen manier te skryf op die rekening van mense nie, maar bly die werk van God wat deur sy Woord self sy eie hoorders, self die gehoorsaamheid aan sy eie aanspraak, skep.

God neem egter die mens ook mee in sy veranderende en vernuwende werksaamheid in die wêreld. Nie alleen kom die krag tot verandering tot mense nie, maar ook die wyse waarop hierdie verandering in hulle lewens vergestalt kan word. God red 'n mens nie maar net om hom of haar daarna aan hulle eie genade oor te laat wat betref die internalisering van die redding in die konkrete lewe nie. Indien die wet (hier verstaan as die gebod tot'n lewe in gehoorsaamheid, oftewel tertius usus legis ) verkondig word soos dit hoort, dit wil sê binne die raamwerk van die evangelie, bied dit steeds die beste wyse waarop hierdie evangelie geëksistensialiseer kan word. Die wet is niks anders nie as die noodwendige vorm van die evangelie, waarvan die inhoud die genade is (Barth 1935:11). Of, andersom gesê: in die Gees kom die wet terug in die vorm van die evangelie ( Van Ruler 1974:526 e.v.).

In wettiese preke word hierdie wesenlike verband tussen die wet en die evangelie uitmekaargeskeur, met die gevolg dat die evangelie enersyds vergeestelik en die wet andersyds, soos ons al telkemale gesien het, gemoraliseer word. Albei prosesse het werklikheidsvreemde, dit wil sê kontekslose prediking tot gevolg. 


\subsubsection{Die vergeesteliking van die evangelie}

In die preke wat ek onder oë gehad het, kom daar talle voorbeelde van wêreldvermyding (konteksloosheid) voor. Ek haal uit 'n meditasie oor Jakobus 4:13-15 aan:

"Tyd is kosbaar - vra maar wat een uur vir 'n sakeman kos. Tog gebruik ons tyd asof dit waardeloos is. Tyd het geen toekoms nie, maar net 'n verlede omdat ons geen waarborg het dat ons net-nou nog sal lewe nie. Ons kan wel terugkyk na wat ons met ons tyd gemaak het. Tyd is dikwels soos weggooibare produkte. Fy gebruik dit slegs een maal en dan is dit onbruikbaar. Hierdie tyd moet met wysheid gebruik word. Dit moet gebruik word om nie net met die tydelike, soos kos en klere en ander aardse behoeftes, soos sport en ontspanning, gevul te word nie, maar behoort ook met aspekte wat ewigbeidswaarde het, soos jou verbouding met God, Bybel lees, bid, kerk toe gaan, vir ander te belp en by te staan, of tyd met jou buzveliksmaat of kinders en ander familie, gevul te word."

Gevolgtrekking: tydelike dinge het nie ewigheidswaarde nie. Maar waarom het Christus dan in die tyd gekom?

Dié vergeesteliking van die evangelie kom in een of ander vorm in feitlik alle moralistiese preke voor. Ek verwys na'n preek oor 1 Johannes 2:18-27. Op die oog af lyk dit asof die preek aktuele temas aanspreek, maak dit ook kwistig van begrippe gebruik wat in 1995 in die "nuwe Suid-Afrika" 'n bepaalde relevansie gedra het, soos byvoorbeeld "inhuldiging", "bemagtig...- dis mos die modewerkwoord in ons tyd", "bedenklike tydskrifte", "Grondwetskrywende vergadering", "vakunie - of personeelvergaderings", "menseregte", "HOP", "Christengodsdiens in ons skole", "nuwe wette", ensovoorts. Maar wie enigsins dieper in die preek delf, kom gou af op die stereotiepe dualisme wat hierdie en ander wettiese preke kenmerk. Menseregte word van meet af aan teenoor die regte van die Verlosser van mense gestel; die HOP teenoor die offer aan die Here en die gee van geestelike gawes ("ons as Christene het nie 'n HOP nodig nie"), ens. Dwarsdeur die preek word die nuwe Suid-Afrikaanse werklikhede gekontrasteer met sogenaamde "geestelike" werklikhede, en die kontras nog verder geradikaliseer deur alles in 'n apokaliptiese raamwerk te giet: ons leef in Suid-Afrika in die laaste uur, waarin antichristelike magte optree, ja die duiwel self (vgl. ook 3.7.5). Die "oplossing" is 'n simplistiese "resep" (sic), naamlik dat ons weer op Pinksterstandaard moet kom, 'n standaard wat ons egter uit die uitdagende en konkrete werklikhede om ons heen wegvoer. Op die keper beskou, bied wettiese preke op een of ander wyse altyd simplistiese oplossings - doen a en b sal volg. Dit maak hoorders óf verbete of moedeloos as die resep in hulle nie geval werk nie - wat nogal dikwels gebeur. 
Simplistiese oplossings verreken nie die kompleksiteit van die werklikheid nie, gebruik dit hoogstens as 'n aanloopbaan om die "geestelike dinge" van die evangelie te verkondig. Keer op keer blyk dit uit moralistiese preke: aktuele sake word wel in die preke ingevoer, maar bloot as 'n tipe "dekor" waarteen die "geestelike" evangelie op die planke gebring word. Die sake word nie self inhoudelik gepak of positief gevul met die belofte van die veranderende krag van die evangelie nie, eerder as die teenpool daarvan gesien. Dit is myns insiens mislukte aktualisering.

Soos ek gesê het, lyk dit op die oog af wel of 'n hele aantal preke oor aktuele, Suid-Afrikaanse sake handel. Wat egter keer op keer uit die analise van hierdie preke geblyk het, is die neiging om die situasie in Suid-Afrika as 'n soort kla-lysie aan die begin van die preek in te voer, en dit dan as 'n springplank na 'n verinnerlikte godsdiens aan te wend, 'n godsdiens waarin daar nie veel hoop gebied word, anders as dat mense deur 'n lysie van godsdienstige reëls Suid-Afrika weer moet "regruk" nie. Die kla-lysie aan die begin van die preek word gekomplementeer met 'n moralistiese doen-lysie aan die einde van die preek. Soos in dié preek oor 2 Kor. 4:8,9;17-18:

"Baie mense het gedink dat as 'n ander politieke party in ons land aan bewind sou kom, ons in 'n soort utopie sou wees. Dat alles net reg gaan loop. Gou het ons uitgevind: dis nie so nie. Daagliks hoor ons van
- verkragtings
- polisie-moorde
- gezveld
- motorkapings
- rowery

En die vraag is: Wat is volgende?

Maar hoe sou Paulus op al hierdie dinge gereageer het? Paulus sê: ek gee nie moed op nie. En dis die boodskap wat ek graag vanmôre by $u$ wil tuisbring - moenie moed opgee nie. God is in beheer. Hierdie ligte verdrukking is maar vir 'n oomblik. Dit gaan verby, en God berei ons voor vir die ewige seën wat Hy ons sal gee...”

Dan volg die lysie van dinge wat ons moet doen om nie moed op te gee nie:

- Om betrokke te bly by die geestelike oorlogsvoering teen die Satan

- Om jouself geestelik op te knap in terme van jou gebedslewe, verhouding met God en jou gevegsmondering

- Om gereeld kerk toe te gaan 
Is dit regtig die (enigste) manier waarop die verkragtings, polisie-moorde, geweld, motorkapings en rowery teëgewerk moet word? Is dit ál wat die evangelie daaroor te sê het? Moet alles so "innerlik en geestelik" gesien word? Is die huidige Suid-Afrikaanse situasie regtig bloot 'n "teken van die tyd" (ligte verdrukking), wat dus in 'n sekere sin maar aanvaar moet word - solank jy net geestelik paraat en gereed vir die wederkoms (ewige seën) is? Ek dink nie so nie.

Dié (wettiese) verinnerliking van ons Suid-Afrikaanse probleem gaan dikwels in preke gepaard met 'n versmalling van die etiese dimensies van Bybelse tekste. Dikwels mis predikers gewoon die asemrowende moontlikhede wat in die teks opgesluit lê. Wanneer daar byvoorbeeld gepreek word oor 1 Joh. 3:18: Liewe kinders, ons liefde moenie net woorde en lippetaal wees nie, maar moet met die daad bewys word, en dan in opregtheid, sou 'n mens kon verwag dat die daad-karakter van ons liefde die logiese saak is wat aan die orde gestel moet word. Die prediker verkies egter om vas te bly steek by die kwessie van vergifnis. "Daar is geen daad wat liefde so volkome bewys as die daad van opregte vergifnis nie." Dat vergifnis belangrik en Bybels is, sal niemand wil ontken nie. Maar, is dit in die eerste plek waaroor die teks handel? Praat die konteks nie juis van aardse besittings en die konkrete dien van mekaar daarmee nie (vgl. verse 11-17)? Die prediker verpas die etiese uitnodiging van die teks, en laat die hoorders eerder op hulleself inkeer met die vraag: Het ek genoeg vergifnis in my hart?

Hierdie verpassing van die moontlikhede van die Bybelse teks is besonder duidelik in 'n meditasie oor die wonder van die broodvermeerdering (Matt. 4:14-21). Die prediker neem 'n frase uit die teks (vers 18: "Bring dit hier vir My.") en verander daarmee die broodwonder in 'n wet van individualistiese bekering. Sinne soos die volgende onderstreep die moralistiese omslag: "As jy bereid is om jou lewe onvoorwaardelik aan My oor te gee, is Ek (fesus) bereid om van jou iets wonderliks te maak." Dat die broodwonder 'n teken is van hoe die koninkryk van God konkreet ook in hierdie wêreld aanbreek - met mense wat só gevoed word dat hulle (werklik) nie meer honger ly nie - verstaan die prediker nie veel nie. Ook nie van die kerk se roeping om (sulke) tekens van die koninkryk op te rig nie. Hy verander dit eerder in ' $\mathrm{n}$ individualistiese suksesresep, met die retoriese motto wat soos 'n refrein deur die preek weergalm: "Bring dit hier vir My" -

"God laat nie toe dat sy ware kinders'n bespotting gemaak word nie.

God wil ook so vandag in jou nood ingryp.

Dalk is jou finansies maar bitter karig.

Dalk is jou buwelik baie wankelrig.

Dalk is jou besigheid besig om onder te gaan.

Dalk is jou verhoudings met jou familie baie swak.

Bring dit hier vir My!" 
In preke soos hierdie verval, soos ons reeds in 5.8 aangetoon het, 'n basiese Gereformeerde uitgangspunt, naamlik die oproep, nie tot 'n algemene, religieuse geestelikheid nie, maar om die ganse lewe en aarde te heilig. Die strewe na die eer van God in alles, die verkondiging van 'n wêreldtransformerende evangelie, is immers ons opdrag.

Soos reeds gesê, gaan die meeste moralistiese preke by die natuurlike leefwêreld van die hoorders verby, en dus ook die hoofbestandeel van hulle elkedagse werklikheid. Hierdie werklikheid word slegs op een wyse "binnegeval", naamlik deur 'n versmalde, "buitengewone" imperatief: wees 'n sendeling. Op 'n cliché-agtige wyse word hoorders by herhaling vermaan om te gaan getuig - meestal ook bloot verbaal verstaan:

"waar ons beweeg, in die skool, op universiteit, in ons werk, in die straat, in die huis..."

"om uit te gaan en buitekant te gaan uitskreeu en uitjubel so bard soos jy kan: Jesus Christus leef."

Sulke algemeenhede sê alles...en niks. Dit hang die voer so hoog en so algemeen op, dat dit 'n wet word, 'n wet wat geen mens kan nakom nie, wat hom of haar Sondag na Sondag in 'n geloofsdepressie kan laat beland. Dat die gelowige geroep word om in die werklikheid en alledaagsheid van sy of haar profane en humane eksistensie te lééf, kom selde op 'n konkrete wyse in die oog. Die homiletiese beweging na die innerlike van die menslike psige, waaroor ek dit reeds gehad het, wreek hom daarin dat die werklike werklikheid in die meeste preke in feite buite die gesigsveld bly. Selfs die mees basiese aangeleenthede, waarvan die openbare media vol is, skitter in hulle afwesigheid! In plaas daarvan word hoorders telkens weer en telkens sonder sukses geroep tot 'n soort missionêre aktiwiteit wat benewens die alledaagse ook nog 'n besondere, kerklike religieuse diens vorder. Dat daar so iets is soos 'n verskeidenheid van gawes, en dus ook 'n verskeidenheid van opgawes, kom nie prinsipieel in die spel nie. Hoorders word gewoon ooreis, oorvra - dalk omdat die predikant hulle na sy eie beeld wil vorm, 'n beeld wat ontspring uit sy eie religieuse ghettoebestaan? Ons word tog nie almal geroep om klein (of groot!) predikantjies te wees nie, word nie almal opgevorder om klone van die kansel te word nie. Die grondliggende fout by preke wat dít wil, is onder meer om op te roep tot 'n soort getuienis versus die alledaagse, terwyl die alledaagse self ten diepste verag, of in elk geval as so sondig en onveranderbaar bejeën word, dat die feit dat God juis hier "mooi word" (Bohren) prinsipieel met agterdog bejeën word. As gevolg van 'n verkapte gebodsprediking word 'n gesonde skeppingsetiek deur 'n eensydige versoeningsetiek verdring, wat werklikheidsvreemde resepte bied. Die versoening van die kruis voer ons egter op 'n kruisweg 
die werklikheid binne, waar resepte nie werk nie. Dit impliseer stryd met die werklikheid om die werklikheid ontwil, 'n stryd wat telkens weer ander gestaltes kan aanneem, en waarin God die belofte van die evangelie telkens weer op 'n nuwe manier kan ontsluit.

\subsubsection{Valse teenstellinge}

Nog 'n retoriese tegniek wat in hierdie verband spesiale vermelding verdien, en miskien die uitmekaarbreek van die werklikheid voor God deur die verkondiging van 'n vergeestelikte evangelie die beste illustreer, is die gebruik van valse teenstellinge.

Wanneer 'n prediker verklaar: "Elke siel moet as potensiële bemeling beskou word." is dit eerder Plato as die evangelie wat die botoon voer. Die evangelie maak tog van ons mense, ware mense, nie siele of engele nie! Sulke teenstellinge vervreem mense van die werklikheid, sodat dit geen wonder is dat baie begin reken die evangelie is óf onhaalbaar óf vir ' $n$ ander planeet of tyd bedoel nie.

Dis ook wreed. Soos in die volgende sinne:

“' $n$ Kind van die Here loop met 'n glimlag op sy gesig rond, 'n kind van die Here móét juig, want by bet dan die grootste geskenk van alle geskenke ontvang... Op 'n kind van die Here se gesig moet daar altyd 'n lied wees, altyd 'n glimlag wees, want ons is dan vrygemaak, losgekoopte mense uit die sonde van bierdie wêreld. Daarom kan ons nie anders as om te juig en vrolik te wees nie. Ons moet sing."

Is laasgenoemde moet 'n indikatief of 'n imperatief? Helaas, 'n imperatief wat nie alleen 'n onmenslike standaard aan die gemeente stel nie, maar aan 'n groot gedeelte van die Bybelse getuienis aangaande die aard van die geloof verbygaan - dink maar net aan die klaagpsalms! Dawid kon beswaarlik altyd glimlag. Of Paulus. Of ons. So 'n eis is onwerklik - ook Bybels gesproke - en daarom onwerkbaar. 


\section{Preekvoorbeeld 3 \\ KAN DIE KERK KNIEL? \\ (Johannes 13:1-17)}

\section{“Here, gaan U my voete was?” (Joh. 13:6)}

By geleentheid het 'n Rooms-Katolieke priester genaamd Pausch 'n erediens meegemaak wat hom tot die dag van sy dood sal bybly. Dit was 'n nagmaalsdiens en daar was 'n groep jong seuns in die kerkgebou, afkomstig van die kloosterskool net langs die kerk. Dié Sondag was daar, soos gebruiklik in die Rooms-Katolieke kerk, 'n voetwassingseremonie, as voorbereiding vir die gebruik van die nagmaal. Priester Pausch, wat die liturg was, het die seuns genooi om voor op die trap van die liturgiese ruim te kom sit, en hy het, skotteltjie water in die een hand en afdroogdoekie in die ander, by die een punt begin om die seuns se voete te was. Toe hy by die laaste seuntjie kom, bemerk hy tot sy verbasing dat dié nog sy sokkies aan het. Voordat priester Pausch nog iets kon sê, fluister die seuntjie dringend: "Vader, my sokkies is ook vuil. U moet dit asseblief ók was!"

Priester Pausch het besluit dat dít nie die geleentheid was om met die seun hieroor te verskil nie, en omdat hy nie iemand was wat hom selfs deur vuil sokkies laat intimideer het nie, het hy, so goed hy kon, die seun se sokkies saam met sy voete in die kommetjie water gewas. Toe hy klaar was, het die seuns hulle plekke ingeneem - almal, behalwe die seun met die nat sokkies. Dié het 'n waterspoortjie deur die kerkgebou gelaat en by die agterdeur uitgeglip.

Priester Pausch het hom ná die diens gaan soek en aangetref in sy kamer waar hy opgekrul op sy bed gelê het, nat sokkies en al, en onbedaarlik snik. Die priester het sy sokkies uitgetrek, sy voete afgedroog en gevra wat die seun pla. Tussen die snikke deur het hy geantwoord: "Vader, ek was nog altyd bang vir die water van die voetwassing, omdat ek bang is vir die genade van God, $j a$, vir God self. Ek wou Hom nog nooit te na aan my lyf toelaat nie, Hom nog nooit toelaat om onder my vel in te kruip nie. Ek het gedink my sokkies sal die water én die Here weghou, uithou - en toe gebeur dit nie. Toe u my voete was, bet die water my geraak, was dit vir my so ontblotend, so ontmaskerend, maar so verblydend, so bevrydend. Ek buil, ja, maar ek huil van blydskap. Want weet $u$, toe ek $u$ so sien buk en my voete was, het ek met verligte geestesoë die Here fesus self sien buk en my voete was. Ek, onverdienstelike sondaar - Jesus het my voete gewas! Goddank, my dun geweefde verweer het Hom nie gekeer nie."

Kyk, of dit nou 'n Rooms-Katolieke knapie of 'n stoere Gereformeerde 
kerkvader is, ons almal het mos hierdie neiging, hierdie ingeboude meganisme wat die Here van ons lyf af wil weghou. Ons keer en weer God weg. Ons werp rookskerms op, bou mure, trek sokkies aan... Trouens, dis mos wat die waardesisteem van die wêreld dikteer: bly in beheer, reguleer en regeer. Behou jou greep op dinge. Moet niemand te naby aan jou toelaat nie. In dié wêreld is daar nie plek vir brose en ontblote, vir breekbare en gebroke mense nie. Jy het niemand nodig nie. Jy is 'n eiland. Onafhanklik. Sterk. Nie 'n weke afhanklike nie, maar 'n onkraakbare rots. Jy laat nie sommer enigeen jóú voete was nie - om nie eens te praat van die moontlikheid om ánder se voete te was nie!

Ons is nie die eerstes wat so dink nie. Petrus se vraag en stelling is tipies menslik: ... "Here, gaan $U$ my voete was?... U sal in alle ewigheid nooit my voete was nie!" (v. 6,8). Op die oog af lyk Petrus se opmerking in orde. Dit spreek oënskynlik van groot eerbied. Dit is ook nie so dat Petrus fout vind met die gedagte van 'n voetwassing nie. Dit was immers algemene gebruik. Mense het met oop sandale op stowwerige paaie gereis, met stowwerige voete oor deurdrumpels getree. Enige goeie gasheer sou reëlings tref vir'n voetwassing. Maar 'n slaaf moes dit doen, 'n beidense slaaf, die laagste klas denkbaar.

Maar Jesus? Is dit nie Hy wat deur die land gereis het en sy almag oor die duiwels en siekte en dood geopenbaar het nie? Skares het gestroom om na sy leringe te luister. 'n Enkele woord van Hom en stormwater word stil, kreupeles loop, blindes sien, dooies staan op. Hy sou tog Jerusalem binnegery kom terwyl die kinders voor Hom uitroep: "Hosanna vir die Seun van Dawid! Loof Hom wat in die Naam van die Here kom! Prys Hom in die hoogste hemel! Die Koning van Israel!" (vgl. Matt. 21:9; Joh. 12:13)

"Here, gaan U my voete was?" Petrus se vraag openbaar 'n basiese misverstand wat ons almal in verband met die Here én sy kerk het. Ons reken heerlikheid en diensbaarheid staan teenoor mekaar, koningskap en knegskap sluit mekaar uit. Trouens, ons redeneer só: hoe meer diensbaarheid, hoe minder heerlikheid; hoe meer knegskap, hoe minder koningskap! Ons begryp nie Jesus se vreemde heerlikheid nie. Dis 'n nederige heerlikheid en 'n heerlike nederigheid. Ons verstaan nie dié grondreël van die evangelie nie: "Die Seun van die mens het ook nie gekom om gedien te word nie, maar om te dien en sy lewe te gee as losprys vir baie mense." (Mark. 10:45)

Soos 'n goue draad loop hierdie wonderlike paradoks deur die Nuwe Testament, in die besonder ook deur Johannes 13. Nie minder nie as elf keer word Jesus aangespreek as Here of Leermeester of Seun van die mens. Die Griekse woord vir Here, Kurios, is 'n magsnaam, 'n almagsuitdrukking. Leermeester dui op iemand met hoë aansien in die samelewing. Die Seun van die mens is 'n glansryke term uit die Ou Testament wat Messiaans op Jesus se ewige heerskappy dui, sy koningskap oor alle nasies. Maar hoe tref 
ons hierdie Here, hierdie Leermeester en Seun van die mens in Johannes 13 aan? In 'n knielende kneggestalte, met 'n skotteltjie water en 'n afdroogdoekie in die hand! Die Koning met 'n voorskoot aan!

'n Biskop genaamd Martinus het een nag 'n droom gehad. 'n Skitterende figuur het aan hom verskyn, so heerlik dat Martinus hom selfs in sy droom amper nie kon aanskou nie. "Ek is Christus," het die figuur gesê, "Ek bet jou kom beloon vir jou toewyding."

"Maar waar is die merktekens in u hande en voete?" vra Martinus.

"Ek het nie merktekens nie," antwoord die figuur, "Ek is pure beerlikbeid."

"Gaan weg van my, Satan," het Martinus geantwoord, "die Christus wat ék dien, is die gekruisigde." En die Satan - want dit wás die Satan - het van hom af weggegaan...

Die wêreld bied ons baie Christusse. Wondlose, ongemerkte, ongebroke Christusse. Hulle kan ons nie red nie Daar is net een Here wat kan: die gekruisigde. Daar is net één Kurios wat kneg is - die kneg wat Kurios is. Net Hy kan ons bevry tot ware diens aan ons medemens. Want dit is wat die kerk is, dit is wie ek en jy is: mense wie se voete gewas is, sodat ons ook ander se voete kan was. Hierin lê die basiese gestalte van die kerk, ja, die basiese toets vir die kerk: "As Ek, wat julle Here en julle Leermeester is, dan julle voete gewas het, behoort julle ook mekaar se voete te was. Ek het vir julle 'n voorbeeld gestel, en soos Ek vir julle gedoen het, moet julle ook doen." (v. 14,15)

Die vraag is nie allereers hoe indrukwekkend ons organisasie of hoe funksioneel ons strukture of hoe fyn geformuleerd ons geloofsbelydenisse of hoe ortodoks ons teologiese teorieë is nie. Die vraag waarby alles staan of val, is: Kan ons kniel? Voor God. Maar ook voor ons medemens. Ook dié met vuil voete...

Dit glo ek: die toets vir die kerk in Suid-Afrika in die jare wat kom, gaan die vraag wees of ons letterlik op voetsoolvlak ons medemens in navolging van Christus ons Here kan dien; of ons nie net hoorders van die Woord is nie, of selfs praters nie, maar daders, doeners, dieners - voetwassers!

Kyk mooi. Daar kniel nóú Iemand by jóú voete. Hy het die kroon van 'n Kurios op sy kop. Hy het ook die kommetjie van 'n kneg in sy hand.

$\mathrm{Ag}$, as ons ten minste net met nat sokkies van Hom af sal weggaan...

(Oorgeneem uit: Johan Cilliers: Daar is 'n God vir gebrokenes) 
HOOFSTUK 6

\section{Die lewende stem van die evangelie: wanneer die prediker praat}

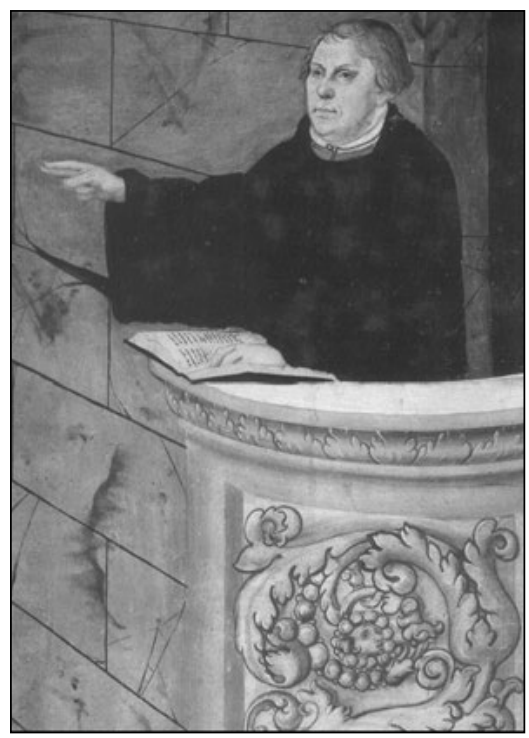

In hierdie hoofstuk word gekyk na die rol van die prediker in die preekmaakproses, in die lig van

- Die prediker se persoonlikheid en spiritualiteit

- Die uitdaging om kreatief en verbeeldingryk te preek, en

- Preekvoorbeelde van die mislukte (moralistiese) funksionering van predikers 


\subsection{Die geheim van die prediking: om mondig te word}

"Die evangelie moet nie geskryf word nie, maar uitgeroep word... die kerk is nie 'n pen-buis nie, maar 'n mond-buis." Met hierdie uitspraak beklemtoon Luther die feit dat die prediking 'n bepaalde orale onmiddellikheid en dringendheid het; dat dit 'n persoon (Persoon!)-tot-persoon gebeure op 'n bestemde tyd en plek is (vgl. Meuser 1969:19, 30). God se Woord is primêr 'n gesproke Woord, 'n daad-gebeure, 'n daad-kragtige dabar. Prediking wat dít nie verstaan en in aanmerking neem nie, bring die wesenlike van die Woord in gedrang.

Stel jouself voor 'n prediker is ná 'n week se worsteling met die teks gereed om te preek, maar word ongesteld net voor die diens. Hy of sy sou die uitgeskrewe preek kon laat sirkuleer en elke gemeentelid sou dit in stilte kon deurlees, of 'n voorganger sou dit namens die prediker kon doen. So 'n gesimuleerde voordrag, oftewel stem-in-absentia is immers nie 'n onbekende gebruik by sommige politieke - en ander byeenkomste nie. Dit kán moontlik van betekenis vir sommige wees, maar in die erediens kan dit tog nooit die ware Jakob vervang nie. Die afwesigheid van die stem, en dus van die persoon van die prediker, skaad die wese van die prediking as 'n persoonlike, en dus menslike uitdrukking en verwoording van die Stem van God.

Die prediker sou uiteraard 'n kassetopname van sy of haar stem kon stuur, of 'n video-opname, of nog beter: per telefoon of satelliet-televisie met die gemeente kon praat. In die toekoms sal predikers dalk "teenwoordig" kan wees deur middel van 'n drie-dimensionele hologram. Goed en wel, maar tóg ontbreek iets, ontbreek dít wat tot die wese van die prediking hoort, naamlik die persoonlike en dinamiese oog-tot-oog-kontak, die lewende kommunikasie wanneer prediker en gemeente mekaar op 'n spesifieke tyd en plek in die teenwoordigheid van God in die erediens ontmoet. Inderdaad: die evangelie moet in die preek deur die mond van 'n mens uitgeroep word (vgl. Wilson 1995:47).

\subsection{Die ek in diens van die Ek}

'n Belangrike stem wat gehoor word op die kansel, is dus die stem van die prediker self - en ek bedoel daarmee nie net sy of haar fisieke stem nie; eerder die totale menswees, eerder die teenwoordigheid van die prediker as persoon. Hierdie empiriese werklikheid kan tog nooit oor die hoof gesien word nie: Wie op die kansel staan, is 'n mens van vlees en bloed, met 'n eie geskiedenis, 'n eie verhaal en 'n eie worsteling met God. Trouens, wie op die kansel probeer om enigiets ánders as haar- of homself te wees, maak ook van die prediking iets anders as wat dit veronderstel is om te wees. Op 
die kansel staan nie in die eerste plek 'n retoriese reus of 'n beskeie boodskapper of 'n betowerende verhaalverteller nie, maar 'n mens soos sy en hy wérklik is - coram deo, voor God. Dalk is daar te veel klone op ons kansels, eerder as oorspronklike skeppings. Dalk is daar te veel aangeleerde maniërismes, wat van geen mens 'n prediker kan maak nie. Met apologie aan alle predikers: elke voël moet sing soos hy (of sy) gebek is. As jy ánders wil sing as wat jy gebek is, is jy vals - in meer as een opsig van die woord.

Hierin sit daar altyd 'n soort spanning: die prediker staan nooit in die prediking op die voorgrond nie, mag tog nooit die hooffiguur in die drama van die preekgebeure word nie, maar is eerder een wat saam met die gemeente luister na wat God sê - als hoorder onder de hoorders, soos die bekende boek van Dingemanns (1991) getitel is. En tog is dit jy wat voor die gemeente staan, met jou kennis van die gemeente, jou teologiese insigte, jou eie persoonlikheid, beperkinge en potensiaal - en nie bloot 'n bandmasjien wat jou stem meganies in die ore van die gemeente laat opklink nie. In die prediking word die waarheid letterlik deur die menswees van die prediker beliggaam: "Authentic preachers are those who embody the Gospel they proclaim in their manner of delivery." (Ward 1992:129). 'n Mens dink ook aan die bekende uitspraak van Phillips Brooks: "Preaching is communicating divine truth through human personality." (1964:5)

Hierdie spanning kan ook anders beskryf word: 'n prediker word gekenmerk deur nederigheid én gesag. Een van die groot versoekings vir die prediker is om aan die een kant sy of haar rol in die preekgebeure geheel en al te oorskat, en 'n soort homiletiese ekshibisionis te word. Almal wat al gepreek het, weet van die versoeking om gewild te wees. Luther het ook daarmee geworstel, en tot die volgende slotsom gekom:

"As jy reken dat jy geleerd is en dat jy die doel bereik bet, en as jy trots voel oor jou boekies, leringe en geskrifte, asofjy wonderlik gedoen en wonderlik gepreek bet, en as jy baie tevrede is omdat mense jou voor ander prys of as jy geprys moet word of anders voel jy teleurgesteld en reg om moed op te gee - as jy so redeneer, my vriend, gryp jouself maar net aan jou ore, en as jy reg gryp, sal jy 'n paar goeie, lang, ruwe donkie-ore raakgryp. Of doen 'n bietjie meer moeite en versier jouself met goue klokkies, sodat mense jou kan hoor waar jy ookal gaan, bewonderend met bulle vingers na jou kan wys en uitroep: 'Kyk tog - daar is daardie wonderlike man wat sulke uitstekende boeke kan skryf en sulke merkwaardige preke kan lewer!' Dan sal jy die seëninge van die Here mis. Want God weerstaan die hoogmoediges, maar aan die nederiges gee Hy genade." (vgl. Meuser 1983:65)

In die prediking handel dit (onder meer) oor Ek... en ek. Elke preek staan of val met die groot Ek van God, met sy Ek is wat Ek is (Eks. 3:14), wat uit- 
mond in: Ek is die brood van die lewe (Joh. 6:35); Ek is die lig vir die wêreld (Joh. 8:12); Ek is die goeie Herder (Joh. 10:14); Ek is die ware wynstok (Joh. 15:1), ens. Hiervan hang alles af: dat hierdie Ek van God telkens weer in elke preek ter sprake kom en sigbaar word. Elke preek word deel van die geskiedenis en die toekoms van die groot $\mathrm{Ek}$ - of dit is geen preek nie. In diens van hierdie groot Ek staan die klein ek van die prediker. Die klein ek op die kansel is sélf 'n soort preek, is sélf 'n boodskap, of jy nou daarvan bewus is of nie.

Die realiteit is egter dat die klein ek dikwels nie 'n medewerker van die groot Ek is nie, maar 'n konkurrent; dat die klein ek 'n lang skaduwee oor die groot Ek gooi, en Hom in die preek verduister. Dikwels kondig die klein ek - bewus of onbewus - reeds in die eerste sin van die preek sy of haar verhouding tot die groot Ek aan. Dikwels word die teologie, of gebrek daaraan, reeds in die eerste sin van die preek gekonsentreer. Dikwels word die klok van die evangelie al klaar dáár gelui óf stilgemaak, word die prediker tot 'n beliggaming van die evangelie óf 'n wet wat moralisties op die hoorders inwerk. In plaas daarvan dat die klein ek minder word, en die groot Ek meer, vind die teenoorgestelde plaas (vgl. Joh. 3:30; ook Bohren 1988:98-107).

Predikers benodig, soos alle gelowiges, die daaglikse, voortgaande bekering - ook weg van hulle eie ydelheid af. Hulle moet weet: my "sukses" is nie noodwendig gelykstaande aan die evangelie nie. Die gevaar is juis groot dat predikers juis as gevolg van hulle amp of teologiese kennis of bedieningsukses tevrede kan raak met surrogate vir ware bekering, dat hulle so "gewoond" kan raak aan heilige dinge, dat hulle afstomp daarvoor en klinies daarmee begin omgaan. Jy kan die (jou) sonde begin rasionaliseer, in plaas daarvan om tot 'n goeie selfkennis te kom. Jy kan die fyn balans tussen selfverloëning en selfbevestiging misverstaan, en so al prekende self verwerplik word (vgl. 1 Kor. 9:27).

Om 'n prediker te wees, is daarenteen om volwasse nederig te wees, dit wil sê om teologies mondig te word. Hierdie mondigwording is, soos die bekering, 'n voortdurende proses, 'n toename in teologiese onderskeidingsvermoë en dus wysheid. Daarom mag predikers nooit "klaar" wees met hulle teologiese opleiding nie. Dis eerder 'n lewenswyse, 'n daaglikse ingroei in die wysheid. Een van die belangrikste vrae wat trouens van 'n predikant gevra kán word, is: is hy of sy wys? En, hand aan hand daarmee: is hy of sy werklik 'n teoloog? As predikers sê - soos hulle dikwels doen - "ek is nie eintlik'n teoloog nie", verstaan hulle waarskynlik nie wat die woord teoloog beteken nie, en sou dit waarskynlik ook vir die prediking beter gewees het as hulle nie op die kansel gekom het nie. Wysheid en teologie het niks met hoogmoed of met "sukses" in die gebruiklike sin van die woord te make nie, maar met mondigheid, en daarom met nederigheid. 
Nederigheid beteken egter weer nie 'n onderskatting van jou rol in die prediking nie. Wanneer die Gees werk, skakel Hy ons nie uit nie, maar in. Hy werk op 'n teonome resiproke wyse, behou die inisiatief, maar neem ons telkens in diens van die verkondiging van die evangelie. Wat vir óns onmoontlik is, maak Hy moontlik; wat vir ons onmaakbaar is, verander Hy in die maakbare (Bohren 1971:76-77; vgl. verder 6.6).

So verkry ons menslike bydrae in die prediking 'n bepaalde waarde, 'n spesifieke gesag. Ons begrip van gesag is waarskynlik deur karikature daarvan gekontamineer. Die gesag van die prediker lê nie in outokrasie, veral nie geestelike of kerklike outokrasie of burokrasie nie. Ons gesag lê in gebrokenheid; ons bemagtiging in ontmagtiging. Grondliggend vir al ons pogings om tussengangers tussen die teks en die konteks te wees, is 'n bermeneutiek van die kruis. Wie hiérdie hermeneutiek nie verstaan nie, wie nie weet dat jy sterk is as jy swak is nie (2 Kor. 12:10), begryp nog nie die hartklop van die prediking nie. Ons gesag lê immers daarin dat ons nie kán nie, maar omdat God in ons werk, kán ons. Dit lê in die boodskap wat ons verkondig: die kruisdood en opstanding van Jesus Christus (vgl. Paulus se uitsprake in 1 Kor. 1:18- 2:16). Maar die wonder is: dis óns wat dit verkondig! Waarlik, 'n mens kan nie anders nie as om dit dialekties te bely nie: dis die evangelie van Christus wat deur sy Gees in die wêreld verkondig word, maar dis ook óns wat ons monde oopmaak om daaroor te preek (vgl. Hand. 1:8)!

Dis $j y$ wat op die kansel as prediker staan, en daarvoor hoef jy nie verskoning te vra nie. Dis $j y$ met jou gawes, jou roeping, jou unieke verwoording van die evangelie. 'n Mens dink onwillekeurig aan die epiese verhaal van Bart Nel, wat ná 'n veelbewoë geskiedenis waarin hy feitlik alles wat vir hom dierbaar was, verloor het, aan die einde as 'n soort klimaks uitroep: "Ek is Bart Nel van toe af, en ek is nog by." (Van Melle 1968:180) Daar sit inderdaad 'n stuk bevryding daarin om jouself te mag wees, veral ook op die kansel. Predikers het nodig om hierdie vryheid telkens te ontdek en te hérontdek - ter wille van die verkondiging van die evangelie.

\subsection{Die (verhoudings)integriteit van die prediker}

Prediking is nooit 'n onbetrokke oordrag van kennis nie, maar 'n woord wat gebore word uit jou omgang met God, uit jou ontmoeting met God in die teks (Iwand 1964:19). Nooit mag jy wegkruip vir die gemeente nie, nie agter jou korrekte eksegese, of jou vinnige oplossings of jou verbysterende diepsinnighede nie. Nooit mag jou rol en jou masker tussen jou en die gemeente, of tussen jou en die teks en die God van die teks staan nie. Nooit 
mag jy leef bloot volgens die verwagting, die beeld wat ander van jou het, en jouself so vermom nie. Die waarheid het immers 'n manier om op die duur agter elke vermomming uit te kom.

Feit is: wanneer daar eers 'n inkongruensie tussen jou persoonlike en jou publieke persona ontstaan het, is die skrif aan die muur vir jou prediking. In die prediking kom jou eie hart in die gedrang; word jou eie lewe op die spel geplaas. Predikers moet tuis wees in die huis van hulle eie prediking. As jy bloot 'n huurder is, blyk dit gou (Thielicke 1965:14). Nee, ons mag nooit homiletiese huis-huurders word nie, maar eerder tentbewoners, soos Christus wat onder ons kom tent opslaan het (Joh. 1:14)!

'n Preek is nie bloot iets geleerds wat jy aan ander oordra nie, maar iets wat jy graag self wil sê, omdat jy nie anders kán as om daarvan te getuig nie - soos die titel van 'n ander bekende homiletiekboek onderstreep: The witness of preaching (Long 1989). Ons word geroep om getroue getuies te wees, mense wat self ' $n$ voorbeeld is van een wat (eerste) aangespreek is, geraak is, gekwes is, gebreek is, vertroos is deur die teks, ja, deur die God van die teks. Ons is reisigers in die woestyn wat skuilgaan in die tent van die teks, ja, van Christus - en in die prediking na ander wink om saam met ons in die skadu lafenis te vind.

Wie nie die kamers en gange, die hoeke en draaie van die huis van die teks - of die flappe en hoekpenne van die tent! - ken nie, wie nog nie op en af daardeur of daarom gestap het en daarmee vertroud geraak het nie, kan nie ander innooi en verwag dat hulle jou woord daaroor moet glo nie. Wie byvoorbeeld nie saam met die God van Psalm 130 'n draai in die dieptes gemaak het nie, moet nie oorhaastig op die kansel klim met 'n boodskap daaroor nie; wie nie al die stuwing van lofsegging in elke weefsel van jou bestaan ervaar het nie, moet stadig wees om Psalm 150 op die (preek)lippe te neem.

Ons sou bogenoemde ook uit 'n ander hoek kon sê: alle predikers staan in sekere verhoudings wat juis bepalend is vir hulle as predikers, byvoorbeeld jou verhouding tot God (wat jou roepingsbesef insluit), jou verhouding tot jouself (wat dinge soos jou persoonlikheid, psigiese geskiedenis, psigiese gesondheid, ens. betrek) en ook jou verhoudings tot ander mense, in die besonder tot hulle vir wie jy wil preek. Wie nie verhoudingsintegriteit bet nie, mag wel soos 'n engel praat, maar sal beswaarlik toegang tot die barte van mense verkry. As jy byvoorbeeld mense nie liefhet nie, het jy geen reg om vir hulle te preek nie (vgl. Jabusch 1981:51-63).

Daar word dikwels ook in dié verband van die spiritualiteit van die prediker gepraat. Dit ís inderdaad van groot belang vir die prediking. Hoewel ek huiwerig sou wees om te sê dat alles in die prediking daarmee staan of val, of dat my persoon of spiritualiteit as prediker die deurslaggewende verskil is, moet ons die invloed daarvan nie onderskat nie. Onder spiritualiteit ver- 
staan ek: Die totale lewe van die predikant, met al die verboudings waarin so 'n mens staan, onder die gesigspunt van sy of haar roeping om met God te wandel deur die Gees (Gal. 5:16,25).

Die vraag na die spiritualiteit van die prediker - ek verkies die uitdrukking: lewe voor God - is nie net van teologiese belang nie, maar ook relevant uit kommunikasiewetenskaplike oorweginge. Jy kan nie medemense raak as jy nie self (mede)menslik is nie; jy kan nie met passie en integriteit oor God praat as jy nie passie en integriteit hét nie. Die unieke stem van die prediker bring menslikheid in die hele preekmaakproses in, open moontlikhede vir assosiasie en identifisering. Of, teologies gesê: die menslikheid van die prediker gee hande en voete aan die charisma wat deur die Gees van Christus in die lewe van die prediker uitgestort word. Predikers is nié bloot steriele, bloedlose "kanale" waardeur die evangelie tot ons kom nie: die evangelie kom na ons in mensemond en mensewoord - anders sou dit nie ons mense-ore en menseharte kon haal nie. Thomas Troeger praat van "the landscapes of the heart" wat in die prediking verruim moet word, dit wil sê die unieke (psigologiese, sosiologiese, ekonomiese, ens.) interpretatiewe raamwerke waarbinne ons almal leef. Om te preek, is om aanhakpunte te vind by die spesifieke stories, simbole, waardes en rituele wat betekenis aan mense se bestaan gee, om op 'n verbeeldingryke wyse hierdie landskappe van die hart te betree en met die evangelie te verruim. Dít kan jy beswaarlik doen, sê Troeger, as jy nie sélf die landskappe van jou éie hart verken het nie (1999:85-95).

Daar is tans ' $n$ hernude belangstelling in die belang van die persoon van die prediker (vgl. op eie bodem die resente studie van Malan Nel: Ek is die verskil 200l). Dat hierdie beklemtoning nie sonder slaggate is nie, is net so waar. Die teologiese integrasie van stemme in die prediking (van prediker, teks, gemeente en God), kan hier maklik uitmekaarval. Jy kan onder die indruk kom dat álles afhang van jou persoonlikheid, of van die graad van jou spiritualiteit. Dit kan 'n nuwe vorm van moralisme word. Tog neem dit niks weg van die feit dat dit 'n verwaarloosde aspek in die (veral vertekende gereformeerde) homiletiek is wat aandag vra nie.

\subsection{Wie nie bid nie, kan nie preek nie}

Wie oor die lewe van die prediker voor God (spiritualiteit) wil praat, kan natuurlik verskillende weë volg. Ek verwys slegs na een dimensie, wat na my mening egter grondliggend is: gebed. Dis jammer dat gebed so dikwels gesien word as iets wat los van die teologie staan. Trouens, vir baie is die wêreld van die teologie en die wêreld van gebed prinsipieel - of dan ten minste in die praktyk - twee totaal uiteenlopende wêrelde. Dis na my 
mening 'n fatale skeiding. Ons moet eerder sê: teologie is primêr gebed, en gebed is primêr teologie (vgl. Saliers 1994:15). Net so is prediking primêr gebed; dit kan op géén manier daarvan losgemaak en - gedink word nie.

Dis opvallend hoe weinig homiletiekboeke gebed as prinsipiële uitgangspunt neem. Maar, kán ons anders? Spiritualiteit is immers iets wat voortvloei uit jou persoonlike, deurlopende gesprek met God, uit jou eie gebedsbestaan. Gebed stempel jou spiritualiteit, wat weer jou prediking beïnvloed. Gebed moduleer jou preekstem.

Preke kan nie sonder gebed "gemaak" word nie. Bethel Müller skryf aangrypend hieroor: "Die preek is 'n worsteling waarin die prediker klein en arm voel - so klein en arm as in geen ander worsteling nie. Die worsteling bring die oomblikke waarin by van die skryftafel na die knielbank vlug om sy aktiwiteit aan die preek dáár voort te sit - en te bid en te smeek dat die Here bom moet belp en verder onder die dwang van Sy Woord moet lei. In die gebed val sy oorhaastige en onvriendelike gedagtes weg; in die gebed word by verlos van sy "mooi" sinswendinge; in die gebed kry die preek diepte omdat God hom dáár Sy gedagtes in die oor fluister. Dan word die lewende Woordverkondiging in die gebed gebore en op die kansel gehoor." (1961:334)

In die gebed kom onder meer ook die persoon van die prediker soos op min ander plekke aan die orde. $\mathrm{Al}$ die menslike ervarings word ingebring wat nog om verwerking roep: die weerstande wat jy met die Bybelteks ervaar, die versperrings tussen jou en die gemeente, jou lewensvrae en vreugdes. Eugene Peterson skryf: "Prayer is the most deeply buman action in which we can engage. Behavior we have in common with the animals. Thinking we have in common with the angels. But prayer - the attentiveness and responsiveness of the buman being before God - this is buman." (1992: 111) In die gebed word die vrae van ons menslike bestaan na God toe opgehou, in die hoop dat daar lig kom wat jy met die gemeente mag deel.

In 'n sin sou ons kón sê dat gebed die geheim van die prediking is. Dis 'n opmerking wat egter vatbaar is vir misverstand. Jy kan redeneer: as ek net bid, is alles in die prediking reg. Jy kan gebed verander in 'n alibi vir eksegetiese luiheid of homiletiese slordigheid. Jy kan onder die wanindruk kom dat die moralistiese hou van "stiltetyd" - teenoor 'n lewenswyse van gebed 'n waterdigte waarborg vir geslaagde prediking bied. Jy kan gebed probeer inspan as 'n doen-dit-jouself-tegniek om 'n preek aanmekaar te sit of op te kikker. Maar dit is gebed nié. Dit bly 'n gawe van God, wat Hy telkens só aan ons moet gee, só deur sy Gees in ons moet uitstort, dat ons opnuut deur die mond van Christus kan bid (Calvyn; vgl. ook Barth 1969:16-21)

Om 'n Christen te wees, en om te bid, is dieselfde ding (Luther). Om 'n prediker te wees en te bid, is ook dieselfde ding. Gebed bly die grondvorm, die dieptestruktuur van alle prediking (Bohren 1971:104-105). Van Augustinus kom die bekende woord - wat gerus maar op predikers se kansels en 
studeertafels as lewenspreuk opgeplak kan word -: sit orator antequam dictor (eers bid, dan praat). Hy laat hom ook soos volg hieroor uit:

"Wanneer die oomblik om te praat aangebreek het, laat hom (die prediker), voordat by praat, sy dorstende siel na God ophef, sodat by kan uitdeel wat by self ingedrink het, self kan uitgiet wat by opgeneem het... En wie kan maak dat deur ons gesê word wat behoort en soos dit hoort, as alleen Hy in wie se hand ons én ons preke is?" (vgl. Van Oort 1989:18; ook 1991:26)

Vir Augustinus bly die prediking 'n gawe van die Gees, 'n goeie woord, 'n goeie preek (sermo bonus) wat die Gees self in die mond van die prediker moet gee - onder meer ook as antwoord op gebed, nee, as verwoording van die gebed. Preke het gebed nie net nodig nie; in 'n sekere sin ís dit gebed. Preke is die soeke om te vind; die klop dat God moet oopmaak God wat brood gee, en nie 'n klip nie (vgl. Matt. 7:7-11). Kortom: wie nie bid nie, kan nie preek nie. Nie wérklik nie.

In die biblioteek van die Candler Theological Seminary (Emory University, Atlanta) staan daar 'n interessante meubelstuk. 'n Metaalplaatjie verduidelik die geheim daarvan: "Prayer desk or pulpit made for Fohn Wesley about 1740, used by bim in preaching to the miners of Wales." Daar is 'n plek waar Wesley kon staan om te preek, maar ook 'n reling waar hy kon kniel om te bid. Dís hoe ons preekstoele behoort te lyk. Ons preekstoele moet ook bidstoele wees (vgl. Bugg 1992:16).

\subsection{Die deugdelike bestaan van die prediker}

In ' $\mathrm{n}$ sin is dit belangriker wie ons ís, as wat ons sê. Daar is 'n filosofiese spreuk wat lui: agere sequitur esse - 'n mens se aksies vloei voort uit jou wese; wat jy doen (en sê) volg uit wat jy ís. Aristoteles was al van mening - teen die stroom van sy tyd in - dat die etos van 'n spreker belangriker is as die blote bemeestering van retoriese tegnieke. Etos is met die oog op kommunikasie belangriker as logos en selfs patos! Dis ook opvallend dat Paulus, wanneer hy aan Timoteus skrywe om hom aan sy preektaak te herinner, dit eers voorafgaan met 'n verwysing na die deugdelike bestaan van "die man wat in diens van God staan, volkome voorberei en toegerus... vir elke goeie werk.", en dan eers kom met die oproep: "Ek beveel jou... verkondig die woord..." (2 Tim. 3:17-4:2). Deug, integriteit, egtheid vorm blykbaar die bedding waarbinne die ware kommunikasievermoë vir die prediking gebore word. Wie nie in die klein, alledaagse dinge met integriteit kan handel nie, moet nie dink dat hulle die groter dinge van die Koninkryk met integriteit kan anpak nie. Die klein gebare van integriteit kommunikeer lank voordat jy al jou preekgebare op die kansel uitvoer. Stanley Hauerwas skryf: "The way we learn a story, after all, is not just by hearing it. Important and significant stories must be acted out. We 
must be taught the gestures that belp position our bodies and our souls to be able to rightly hear and then retell the story... the way we learn the story is by learning such gestures as simple as how to kneel." (1985: 188) Inderdaad: Lex orandi, lex credendi, lex vivendi, lex praedicandi. Soos jy bid, so bely jy, so leef jy, so preek jy.

Ons moet eers as predikers gemáák word, voordat ons hoegenaamd daaraan kan dink om preke te probeer "maak". Luther het aangrypend hieroor geskryf. Volgens hom is daar drie dinge wat 'n prediker máák, drie basiese elemente in die opvoedingsproses van die prediker as prediker, naamlik gebed, meditasie en beproewing (oratio, meditatio, tentatio). Ongelukkig laat beskikbare ruimte nie toe dat ek hier breedvoerig op elkeen kan ingaan nie. 'n Mens sou inderdaad 'n hele homiletiek hieromheen kon ontwerp! 'n Enkele aanhaling by elkeen mag wel as aptytwekker dien.

- Gebed: "Om bierdie rede moet jy wanhoop aan jou eie wysheid en rede, want daarmee sal jy niks bereik nie... Kniel neer in jou binnekamer en vra God in ware nederigheid en erns om ware wysheid aan jou te skenk... Ek is van oordeel dat my gebed meer as die duiwel self is. As dit anders was, sou Luther lank voor dit anders gevaar het. En tog wil mense nie die groot wonders of wonderwerke insien en erken wat God ter wille van my werk nie. As ek maar net 'n enkele dag sou versuim om te bid, dan sou ek 'n groot deel van die vuur van geloof verloor."

- Meditasie: "In die tweede plek moet jy mediteer, en nie net in jou bart nie, maar ook uiterlik, oor die mondelinge Woord en die uitgesproke woorde wat geskrywe staan in die Boek. Dit moet jy altyd bedink en berbedink, en oor en oor lees met toegewyde aandag en nadenke om te sien wat die Gees daardeur bedoel. En pasop dat jy nie moeg word daarvoor en dink dat jy dit genoegsaam gelees het as jy dit gelees, gehoor of een of twee keer gesê en volkome verstaan het nie. Op só 'n manier word geen groot teoloog gemaak nie, want bulle wat nie aanhou mediteer oor die Woord nie, is soos halfryp vrugte wat op die grond val..."

- Versoeking: "Dit is die ware toetssteen wat jou leer om nie alleen te ken en te verstaan nie, maar om ook te ervaar hoe waar, opreg, soet, wonderlik, kragtig en troosryk die Woord van God is, sodat dit die Wysheid bo alle wyshede is... Want, so gou as die Woord van God vrug deur jou dra, sal die duiwel jou lastig val, sodat jy 'n ware prediker kan word en deur versoeking geleer word om die Woord van God te soek en lief te hê. Want ek self-as ek toegelaat mag word om my nederige mening te lug - moet die papedom baie bedank dat bulle my so lastig geval en gespanne gemaak bet, my so getreiter bet met die duiwel se geweld, dat ek 'n redelike goeie teoloog geword het, wat andersins nie die geval sou wees nie." (vgl. Meuser 1983:75)

Dit alles wil sê: prediking is nie 'n stokperdjie nie, nie 'n blote kerklike aktiwiteit wat jy net maar "professioneel" kan afhandel nie. Dis 'n lewens- 
wyse. 'n Leerskool. Dit gaan deur jou murg en bloed. Jy preek nie bloot nie. Jy ís 'n prediker. Of nie.

Prediking is verborge ekstase: daaragter lê 'n aangegryp wees deur God. Sê iemand dit mooier as Miskotte? -

"De preek is een afgekoelde extase, een gestolde verrukking, maar als daar niet dat tongenspreken achter zit, als daar niet bet een of ander in de biografie van de man die het doet, of in de gemeente waar het geschiedt, achter zit, van deze verrukking der evidentie, der zekerbeid, dan is bet toch niet wat de Geest bedoelt." (1971:257, 259 - in 'n preek oor 1 Kor. $14: 15,20)$

Inderdaad: Wie nie die verrukking van die evangelie ervaar nie, word nooit mondig nie.

Maar, sou mens kon vra: Hóé gebeur dit? Hoe is hierdie verrukking en mondigwording moontlik? Die antwoord lui:

\subsection{Dis die Gees én ons...}

'n Paar jaar gelede was daar 'n merkwaardige student in die manskoshuis Dagbreek op Stellenbosch. Dit was 'n blinde man, genaamd André Steyn. Een aand was daar 'n kragonderbreking op Stellenbosch. Dit was 'n besondere donker aand, sonder selfs 'n strepie maanlig. Die binnehof van Dagbreek was in pikdonkerte gehul; 'n mens kon nie jou hand voor jou oë sien nie.

'n Paar manne was saam by 'n funksie en het gelyktydig by die hoofingang van Dagbreek opgedaag. Voor hulle het die donker binnehof opgedoem. Een van hulle, die primarius Piet Vorster, kry toe die blink ingewing om vir André te vra om hom na sy kamer te lei. André het immers die binnehof soos die palm van sy hand geken, het geweet hoeveel treë jy moet stap voor jy links of regs draai, hoeveel trappies daar was, waar die plekke was waar jy maklik kon struikel.

'n Buitengewone toneel het hom daardie aand afgespeel. André, die blinde wat in die donker kon "sien" het sy vriend, die sienende wat in die donker "blind" was, na sy bestemming gelei - onnodig om te sê, sonder dat hy 'n nerf verloor het.

Predikers moet súlke mense wees, mense wat in die donker - ook van die talle kragonderbrekings van ons tyd - verder en dieper kan kyk, en ander kan help om te "sien", sodat ook hulle by hulle eindbestemming kan kom. Hiervoor benodig ons verhelderde geestesoë, wat alleen die Gees aan ons kan skenk (Efes.1:18). 
Die vraag is nou: hoe "werk" hierdie verhouding tussen die Gees en die prediker? Wat is die resultate of kenmerke daarvan? Kan dit enigsins "gewaarborg" word?

Karl Barth sou - veral in sy sogenaamde "eerste fase" - besonder sterk nee! op die laaste vraag geantwoord het. Vir hom is die belangrikste vraag wat 'n mens in die prediking kan vra, nie soseer: Hoe máák 'n mens 'n preek nie, maar eerder: Hoe kán 'n mens (dit durf waag om te) preek? (1924 : 103). Daarom moet ons in die prediking nie in die eerste plek konsentreer op die metodologie nie, maar op die wonder van die prediking, en die gebed om die Gees: Veni, creator spiritus (Kom, Skepper-Gees) ... (KD IV/3:579 e.v.).

Die enigste "sisteem" wat Barth wou aanvaar, was die oneindige, kwalitatiewe onderskeid tussen God en mens (in aansluiting by Kierkegaard), met al die negatiewe en positiewe implikasies daarvan (1924:13). God moet praat, loodreg uit die hoogte, en dié spreke kan deur geen metode bemiddel word nie. Alleen wanneer die Woord deur die werking van die Gees die mens tref soos 'n weerligstraal 'n boom, kan aan God die eer gegee word. Alle ander dinge is uit die mens gebore en tevergeefs...

Dit wil voorkom of die werk van die Gees en dié van die prediker by Barth in die praktyk beskou word as twee basiese teenpole, of ten minste as twee pole wat slegs van tyd tot tyd op 'n willekeurige wyse byeengebring word. Die Gees kan kom en gaan soos Hy wil, praat waar en wanneer Hy wil (vgl. die kritiese opmerkings van Bohren 196:111 e.v.).

Rudolf Bohren vra daarenteen aan Barth: Waarom kan daar dan geen metode meer wees wanneer God praat en die Gees werk nie? Hyself wil die werk van die Gees en die metodologie nie as teenpole sien nie, maar slegs as verskillende aspekte van die wederkerige verhouding tussen God en mens (1971:77). Rudolf Bohren leun in dié verband sterk op 'n begrip wat Arnold van Ruler die eerste keer in die konteks van sy "relatiewe selfstandige pneumatologie" gemunt het, naamlik: teonome resiprositeit (Bohren 1974:74 e.v.). Met dié begrip wil albei uitdrukking gee enersyds aan die feit dat die verhouding tussen God en mens 'n verhouding is wat op grond van die inisiatief van God ontstaan én in stand gehou word, (= teonoom), en andersyds dat die handeling van die mens 'n wesenlike komponent van hierdie verhouding uitmaak, dat dit 'n bepaalde waarde verkry. Daarom kan Bohren homileties gesproke so 'n klem op die belang van die metode lê, aangesien Gees en metode nie vreemd teenoor mekaar hoef te staan nie. Deurentyd in hierdie wisselwerking (= resiprositeit) behou God egter die eer, is dit sy handeling wat alles moontlik maak en voorop staan - God het ons gemaak wat ons nou is: in Christus Jesus het Hy ons geskep om ons lewe te wy aan die goeie dade waarvoor Hy ons bestem het (Ef. 2:10). Hierdie teonome resiprositeit is nie te verstane as 'n tipe identifikasie van 
God en mens sodat'n mens later nie meer kan onderskei wie doen wat nie, of as 'n teorie waarin mense God se werk komplementeer, dit wil sê tot vervulling bring nie, maar as 'n wyse waarop die evangeliese siening van God se genade en mense se dankbaarheid daaroor tot uitdrukking gebring word.

Hiermee word dus bedoel dat die verhouding tussen God en mens deur God geïnisieer en in stand gehou word, maar dat dit ook 'n egte verhouding is, waarin die aandeel van die mens 'n onontbeerlike element is. Dié verhouding word nie op 'n willekeurige wyse bewerkstellig nie, maar deur die duursame werking van die inwonende Gees. Daarom bly dit 'n wonder wat steeds in die gebed tot uitdrukking kan kom, maar word die "menslike en die maakbare" ook met 'n bepaalde waarde beklee (1971:78).

Hoewel ons die Gees nooit in ons greep kan kry en beheer nie, het Hy tog gekom om te bly! En, beklemtoon Bohren, Hy bly só by ons dat ons kreatief begin "saamwerk", ook in die preekmaakproses.

Hy skenk enersyds aan ons 'n vryheid vir die metode, skep 'n ruimte waarbinne alles wat heilsaam is, betrek kan word: wetenskap, kuns, tegniek, digkuns, ensovoorts - 'n reeks wonderlike "hulpmiddels" vir die verkondiging. Hy verleen aan die prediking 'n meerstemmige, veelkleurige karakter, in ooreenstemming met sy werk veral sedert Pinkster, sy handelinge nie alleen in die skepping, geskiedenis en kultuur nie, maar in die besonder ook in die kerk. Die Gees werk só met ons saam, dat sy werk nie meer beperk is tot weerligstraalmomente nie, maar eerder die karakter van 'n duursame inwoning aanneem (vgl. Cilliers 1994:251-255).

Andersyds impliseer dié vryheid vir die metode 'n kreatiwiteit in die metode. Alles kan beproef word. Die prediking is 'n speelse handeling, waarin die prediker kreatief met woorde, moontlikhede, invalshoeke kan omgaan, waarin hy of sy oop moet wees vir ingewings en metafore om op die beste wyse moontlik te kan sê: "die koninkryk van die hemel is soos...!"

\subsection{Die Gees maak ons kreatief... maar hóé?}

Die Gees maak ons kreatief, en sluit in die proses die eg menslike en maakbare in. Die vraag is nou: Wat ís kreatiwiteit? Hoe "werk" dit? Kan ons byvoorbeeld die bevindinge van die sielkunde van kreatiwiteit vir die prediking benut? Staan die sielkunde van kreatiwiteit en die teologie van kreatiwiteit noodwendig teenoor mekaar?

In die lig van wat ons tot dusver gesê het: beslis nie! Immers, wie oor die Gees dink, dink oor die mens! Wie oor die Gees dink, móét eenvoudig die totale mens ook in die oog kry, met die volle pakket van sy en haar persoonlikheid. Ons sal wel egter die uitgangspunte en bevindinge van hierdie 
en ander wetenskappe telkens onder die "kontrole" van die kreatiewe Bybelteks, die kreatiewe gemeente en veral die kreatiewe Gees moet plaas. Maar die winspunte bly oneindig!

\subsection{1 'N VOËLVLUG OOR DIE GESKIEDENIS VAN KREATIWITEIT}

Richard Kearny beskryf die historiese ontwikkeling van kreatiwiteit met behulp van die klassieke drie-deling van premodernisme, modernisme en postmodernisme, en hou 'n aantal tipiese kunswerke uit hierdie era's voor, kunshistoriese voorbeelde wat kenmerkend van hierdie tydvakke is, en die prinsipiële uitganspunte treffend uitbeeld. Die kunswerke is as 't ware grepe uit die verbeeldingswêrelde van hierdie periodes. Om die tema af te baken, staan ek veral stil by kenmerkende uitbeeldinge van die menslike gesig - met die hoop dat ons daarin ook iets van die "gesig" van die onderskeie periodes kan herken. ${ }^{17}$

Christus Pantokrator (elfde eеu n.C.)

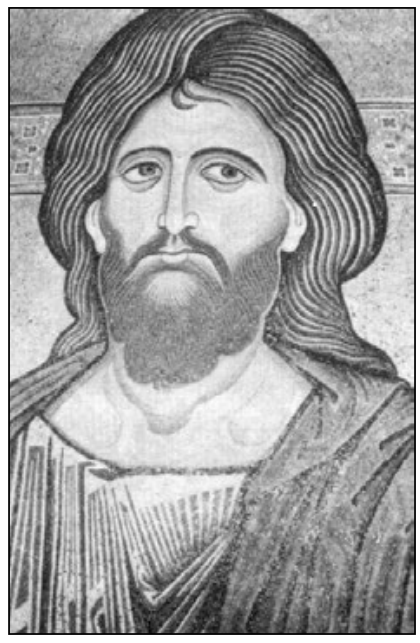

Die eerste skildery verteenwoordig die premoderne fase en heet Christus Pantokrator. Wat dadelik opval, is dat die kunstenaar dit nie onderteken het nie - kenmerkend van die vele ikone uit hierdie tyd. Daarmee word reeds aangedui dat dit nie hier om individuele kreatiwiteit of originaliteit (mag) handel nie - hoogstens kan die kunswerk toegeskryf word aan een van die

17 Thomas (1979:153) maak die veelseggende opmerking dat die uitbeelding van Christus se gesig in die kuns deur die eeue heen ook 'n poging was om ónsself uit te beeld: "In looking on the face of Christ, the work of our hands and minds, we are looking at ourselves, both as we are and as we would like to be." 
groot Bisantynse skole of in die algemeen aan die middeleeuse ikonografie. Die klem lê nie op die kunsproses nie, maar op die waarheid wat dit moet bemiddel. Die onderliggende boodskap is: hierdie werk het sakramentele karakter, dit wys ons heen na 'n groter Werklikheid, naamlik die Seun van God, en ten diepste God self. Dit gaan dus eerder om die Misterie ágter die beeld, as die beeld self.

Dis daarom te verstane dat daar sulke streng reëls en formules bestaan het waarvolgens die kunstenaars in daardie dae moes werk, standaardprosedures in die aanwending van die verf en 'n kerklik voorgeskrewe en streng ingeperkte palet - om alle inmenging van die kunstenaar as kunstenaar uit te skakel in die bemiddeling van die Skepper self.

Opvallend is die uitdrukkinglose oë van die ikone: dit nooi die kyker uit om daarin te kyk, en in die kalm poele daarvan glimpse van die ewige te sien. Die oë funksioneer as poorte na die suprasensoriese transendensie van God, eerder as om die kyker te laat vaskyk teen menslike gesigsuitdrukkings en sensasies. Die ikone het 'n soort teosentriese kwaliteit, deurdat dit die kyker wil help om God deur middel van die beeld te aanbid (Kearny 1988:9). In hierdie uitbeeldings word die spel van die verbeelding dus van meet af aan aan bande gelê en gestereotipeer; word enige ekspressiwiteit, realisme of lewensgetrouheid kerklik-institusioneel gekortwiek.

Vincent van Gogh: selfportret (ca 1888)

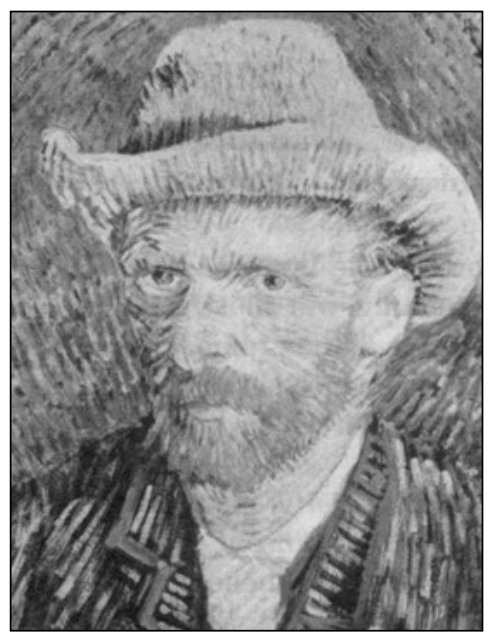

Totaal anders is die selfportrette wat tipies van die moderne era is. 'n Goeie voorbeeld is dié van Vincent van Gogh, waarin die klem lê op die beeld as 'n medium van menslike ekspressie. Teosentrisme maak hier plek vir antroposentrisme, vir 'n estetika van subjektiwiteit. Die basiese humanistiese inslag blyk 
reeds - in teenstelling met premoderne kuns - uit die oorspronklikheid van kleur en forsheid van kwashaal. Hier is 'n mens aan die skep, wat nie skaam is om sy eksistensie op doek uit te druk nie - al is dit dan net sy gepynigde eksistensie. Die sakramentele gebed het 'n eksistensiële kreet geword. Die kalm, bodemlose oë van die ikoniese Christus het verander in oë vol pyn en angs, selfs waansin. Hier is daar nie meer 'n poging om 'n ewige realiteit te reproduseer nie, maar om self die (ontwykende) realiteit te produseer - tot waansin toe. Agter die ellende van Van Gogh sit daar die geloof dat die individu 'n greep op dié waarheid kan kry, of beter: dat die individu dié waarheid self kan verbeeld. Dit vra nie veel verbeelding (!) om vanaf hierdie klemverskuiwing wat al sy aanloop in die Italiaanse Renaissance het - tot by die humanistiese positivisme van volbloed modernisme uit te kom nie. Agter hierdie positivisme sit daar die geloof dat die mens tot oneindig baie in staat is, dat ons byvoorbeeld dié waarheid agter/onder/in alle ander waarhede deur wetenskap en rasionele denke kan laat uitkristalliseer.

\section{Pablo Picasso:}

builende vroue (1937)

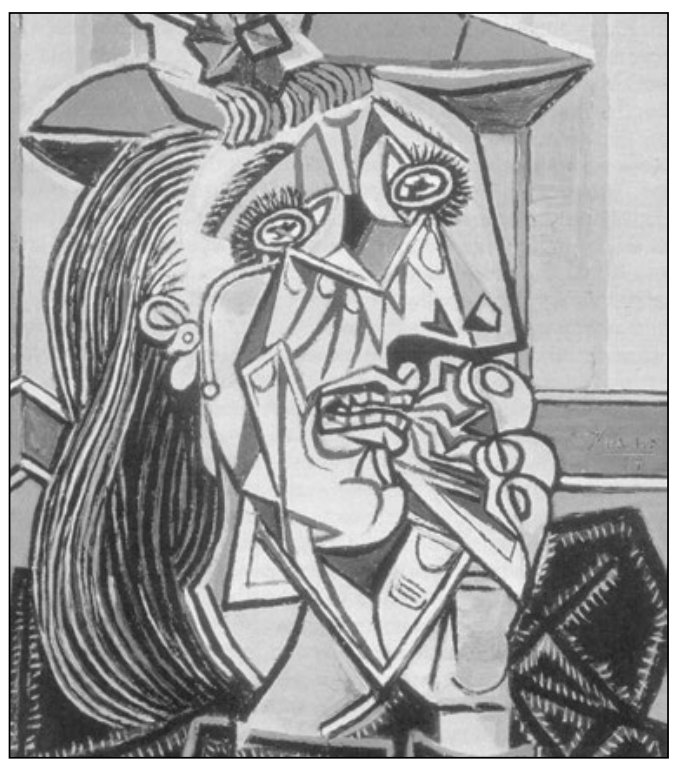

Die gesigsuitbeeldings van Pablo Picasso praat weer 'n ander, postmoderne taal. In 'n reeks getitel "Picasso se huilende vroue", waarin sy kubistiese benadering onder meer blyk, word verskeie gefragmenteerde en subjektiewe perspektiewe van vroue gegee, eerder as 'n enkel, rasionele perspektief. Só dwing Picasso ons om nuut te dink oor ons kennislimiete. 'n Manlike chauvinis sou byvoorbeeld deur só 'n uitbeelding gesteur word, aangesien die outonomie en objektiwiteit van sy stereotipe siening van vroue daar- 
deur in sy kern angetas word. Want wie is hierdie vrou nou eintlik? Moeder? Madonna? Slet? Of, aan die ander kant: 'n (geïndoktrineerde en gestereotipeerde) vrou sou kon vra: Maar is ek dan meer as één gesig? Is daar vir my ánder bestaansmoontlikhede? Dimensies wat ek net nog nie ontdek het nie? Só dwing Picasso se nie-representatiewe, multi-perspektiwiese skilderye ons om opnuut na te dink oor die kloof wat bestaan tussen dit wat ons waarneem en dit wat in werklikheid ís, en oor die moontlikhede van wat ons kan wórd. Skilderye soos hierdie demitologiseer die siening dat ons vooropgestelde konsepte noodwendig "objektiewe duplikate" is van dit wat werklik ís. Dit breek stereotiepe perspektiefvorming tot in die grond toe af.

Die estetiese gevolg van hierdie dekonstruksieproses is tegelykertyd sublieme onsekerheid én genot. Daar is die onsekerheid wat spruit uit die besef dat ons nie (meer) verseker, nie meer objektief kan wéét nie. Maar daar is ook die genot van ontsnapping uit 'n dooie en vervelige konseptuele tronk. Om vars en nuut te ervaar - daarin lê die ontdekkersgenot. Hier word uit die kollektiewe, algemene gebreek, en gewáág. Hier word die gemiddelde agtergelaat, en onbekende waters ingevaar. Hier word gespeel met persepsies, eerder as om dit te vang en in 'n hok of onder 'n blok te sit. Hier word rondom die waarheid gedans, eerder as om dit met 'n ystere greep vas te vang en na jou hand te vorm (vir 'n uitgebreide bespreking van Picasso se oeuvre, vgl. Linn 1996:97 e.v.).

Andy Warbol:

Marilyn Monroe seriografie (1987)

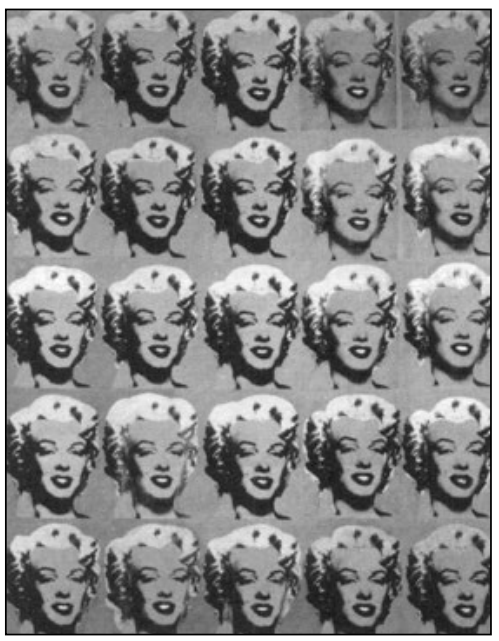

Postmoderne kuns kan egter ook ander, meer siniese trekke aanneem, soos versinnebeeld in die werk van Andy Warhol. 'n Tipiese voorbeeld is sy Marilyn Monroe seriografie. Hier sien ons hoe die teosentriese paradigma 
van die ikonografie en die antroposentriese paradigma van selfuitbeelding plek maak vir'n eksentriese paradigma van parodie (ek-sentries, hier verstaan á la Jacques Lacan: die onbewuste subjek is ek-sentries, dit funksioneer nie as 'n kontrolerende oorsprong van selfekspressie nie; vgl. Moyaert 1981: 35-67)). Al die tipiese kenmerke van postmodernisme kom in hierdie kunswerk na vore: dit is eklekties van aard, en pretendeer nie om oorspronklik te wees of 'n "objektiewe werklikheid" af of uit te beeld nie. Trouens, hierdie vorm van postmoderne kuns produseer nie oorspronklik nie, dit reproduseer bloot wat reeds is of was. Dit staan geheel en al skepties teenoor enige vorm van kuns wat op (die uitbeelding van) waarheid aanspraak wil maak, en parodieer dit. Die diepste dryfveer van hierdie vorm van postmoderne kuns is om die pretensies van modernisme te ontluister, is om die aansprake van 'n kontrolerende outeur, narratiewe orde en metafisiese diepsinnigheid tot op die been toe bloot te lê en as vals te ontmasker. Dit verwerp die magiese status van 'n humanistiese verbeelding en verkondig die "einde van kuns". Kuns word anti-kuns; word nie meer gesien as 'n sprong die toekoms in nie, maar bloot 'n herhaling van gegewens uit die verlede, soos die vervelige her-speel van 'n ou film, tot sterwens toe. Ja, kuns lui die doodsklok vir kreatiwiteit, verbeelding en "die oorspronklike waarheid". Postmoderniste dans al parodiërend op die graf van die moderne idealisme. Jy sou hierdie dans dalk nog "spel" kon noem, maar dis dans wat draaksteek, spel wat afbreek - tot op die bodem toe.

$\mathrm{Al}$ wat daar volgens hierdie parodiërende grafdansers oorgebly het, is om die konsumpsie-mentaliteit en die kommersialisering van die huidige tydsgees uit te beeld, of beter: tegnologies te reproduseer. Individue inisieer nie meer nie; die verglobaliseerde sisteem reproduseer slegs. Dis 'n wêreld vol Coca-Cola blikke en Hollywood Marilyn Monroe's. 'n Wêreld sonder diepte of originaliteit. 'n Wêreld waarin daar 'n volledige inversie van feit en fiksie plaasgevind het (soos die trotse moeder wat vir haar vriendin wat haar spelende kind bewonder, sê: "Dis nog niks nie, wag tot jy sy foto sien!'). Trouens, dis 'n wêreld waarin daar'n totale subversie van feit en fiksie plaasgevind het: jy weet nie meer wat is wat nie. Tipiese postmoderne kuns van hierdie aard verlustig homself in sy eie oppervlakkigheid, sy eie pseudo-status, sy eie representatiewe kunsmatigheid. Dit hekel met konsepte soos "diepte", "waarheid", "objektiwiteit", "normatiwiteit". Dit is die ironie van ons tyd: terwyl ons omring word deur beelde (film, televisie, rekenaars), word menslike verbeelding soos ons dit tot dusver verstaan het, in sy diepste kern bedreig (vgl. Kearny 1988:1-3).

Terwyl die premodernistiese paradigma mimeties van aard was (kuns is soos 'n spieël wat die Goddelike afbeeld), en die modernistiese paradigma op sy beurt produktief van aard is (die kunstenaar is soos 'n lamp wat self die lig skep), is die postmodernistiese paradigma voluit parodies van aard (dit 
reflekteer ook, maar nie soos 'n spieël nie, eerder soos 'n spieёl-in-'n-spieël, 'n labirint van nimmereindigende reproduksies van alledaagse, gekommersialiseerde oppervlakkighede, soos mimiek sonder begin of einde). Tydens die premoderne fase is kunstenaars verstaan as na-makers van die skepping, oftewel dupliseerders van die "oorspronklike" skeppingsproses van die Skepper. Die moderne periode van die Renaissance, die Romantiese en Eksistensialistiese humanisme vervang die teosentriese paradigma van die mimetiese kunstenaar met die antroposentriese paradigma van die oorspronklike uitvinder. Die postmodernisme keer dit alles om: die produktiewe uitvinder word nou 'n eklektikus, iemand wat rondspeel met fragmente van betekenis wat hy of sy nie self geskep het nie. Die kunstenaar word 'n "speler", swerwend in 'n anonieme interspel van beelde wat hy of sy maar net kan parodieer, simuleer of reproduseer.

\subsubsection{WAT KAN ONS LEER UIT DIÉ GESKIEDENIS?}

Die vraag is nou: wat moet ons leer uit die postmodernisme - die era waarin ons tans is? $\mathrm{Na}$ die premodernisme kan en moet ons immers nie terugkeer nie. Hoewel laasgenoemde ons wil oortuig van die realiteit van die objektiewe Werklikheid (en dus van prediking as uitwysing van God op die kansel!) - verlei dit ons ook tot 'n soort demping van die oorspronklikheid van die prediker as kunstenaar, tot 'n onderdrukking van alle homiletiese poësie (en dus die uitwissing van die méns op die kansel!). By die modernisme kan ons ook nie verwyl nie - dit bring weer die mens in die prentjie, maar té ambisieus, té ongekontrolleerd, té dominant. Die beklemtoning van die méns as soewereine, outonome bron van alle betekenis het ons - in hemelsnaam - tog genoeg skade berokken! En die postmodernisme? Dit bevry ons 'n ent weg, maar - en ek praat hier uit estetiese oorwegings - dit stort ons ook in 'n nuwe verknegting.

Dit bevry ons 'n ent weg: ons het Picasso se huilende vroue nodig, want deurdat dit ons herinner aan die limiete van ons gewaande, totalitêre grepe op die waarheid, help dit ons om die modernistiese terreur van die twintigste eeu te oorkom (Linn 1996:100). Ons het hierdie soort kuns (lees: prediking) nodig, want, anders as "mooi", representatiewe kuns wat ons versterk in ons illusie dat ons alles onder beheer het en dat ons konseptuele orde volledig intakt is, herinner die sublieme, nie-representatiewe kuns van Picasso ons aan die genot van die spel met dit wat ons nié kan begryp nie, die genot van die omgang met die Onbekende, die Gans - Andere. Dit herinner ons aan ons kinderdae, aan die onverbloemde vreugde van verbeeldingryke spel sonder sensuur!

Die postmodernisme stort ons egter ook in 'n nuwe verknegting. Selfs kinderspel en onverdunde fantasie gedy slegs binne sekere parameters. 
Sekere vorme van postmodernisme lei juis, soos ek aangetoon het, tot die agteruitgang, en uiteindelike dood van kreatiwiteit. By Picasso vind 'n mens nog vreugde in die skeppingsproses, trouens, die hele proses is daarop afgestem - op ontdekkersvreugde. Druk jy deur na die bodem, voel jy die borrelinge van die alternatiewe. By Warhol is die vreugde by die agterdeur uit. Op die bodem vind jy niks, of hoogstens galgehumor en bitter sinisme. Terwyl die kritiek teen die modernisme geldig en broodnodig is, is die alternatief wat dié spesifieke vorm van postmodernisme bied, "too ghastly to contemplate".

Ons moet dus onderskei tussen sekere vorme van postmodernisme. Die vorm wat deur Picasso verteenwoordig word, bevry ons na my mening wel tot die spel van die prediking (vgl. weer 2.6). Dit leer ons om onsself minder ernstig op te neem, en spelenderwys die rykdomme wat daar ís - wat aan ons gegéé is - te ontdek en te ontgin.

\subsection{Wat is die kern van kreatiwiteit?}

Dus: Hoe moet ons kreatiwiteit definieer? Wat is die kern daarvan? Daar bestaan inderdaad 'n verskeidenheid van filosofiese, opvoedkundige, neurologiese en ander omskrywings daarvan. Breedweg gesproke sou 'n mens kon sê dis die proses waardeur innoverende kombinasies of assosiasies (sommige verkies die term bisosiasies) van reeds bestaande elemente plaasvind, met 'n bruikbare toepassing - "To create consists of making new combinations of associative elements which are useful." (Volgens die neuroloog Martindale)

Dalk sou 'n mens kon sê: hoe meer ongewoon of verrassend die kombinasies, en hoe groter die bruikbare toepassing daarvan, hoe kreatiewer was die proses wat dit bewerkstellig het. Ek verkies die relatief eenvoudige definisie van die bekende opvoedkundige De Bono: "Creativity is breaking out of established patterns to look at things in a different way." Alles hang inderdaad af van die wyse van waarneming, van die persepsie. Hoe waargeneem word, bepaal hoe geskep word - of nie (vgl. weer 3.7).

Ons sou verder kon sê: verbeelding (kreatiwiteit) is iets wat met jou gebeur - daar is nie 'n resep wat dit waarborg nie - hoewel dit ook iets is wat jy moet en kan leer.

\subsubsection{Kreatiwiteit is iets wat met jou "gebeur"}

Wat die gebeur betref: dis 'n neurologiese feit dat gekonsentreerde aandag dikwels juis die grootste struikelblok tot die vind van 'n oplossing is, dat dit as ' $t$ ware die breinsinapse soos sluise laat toegaan. Wat nodig is, is "unfo- 
cussed attention" (Martindale), is die ontspanning en rus ná die harde worsteling met die probleem - 'n ontspanning en rus wat dikwels lei tot die vonk van insig om die antwoord te kry.

Dit kan op die mees ongewone tye en plekke jou "tref", byvoorbeeld onder die stort, terwyl jy draf of in die tuin werk, ensovoorts. Soms is die eerste paar sekondes nadat jy in die oggend wakker geword het, die mees kreatiewe van die hele dag! Wat het gebeur? Jou brein het tyd gehad om die data te verwerk, nuwe verbande en assosiasies te lê. Van die grootste ontdekkings van alle tye het trouens op hierdie wyse tot die ontdekkers gekom: onder 'n appelboom, in 'n bad vol water, op die naat van die rug in 'n wuiwende koringland...

As daar een manier is om nié kreatief te wees nie, is dit om te hárd te probeer om kreatief te wees!

Die goeie nuus vir predikers is dit: om te kan preek, moet jy nie alleen hard aan die teks werk nie, maar moet jy ook sag om die teks heen kan ontspan! Maar ook: om te kan preek benodig jy tyd, kán jy nie - neurologies en metodologies gesproke - jou preek Saterdagmiddag begin maak nie. Jy kan nie gou genoeg begin om jou preek te maak nie, en jy kan nie te lank daarmee aanhou nie. Maandagmiddag is dalk al klaar te laat, en Saterdagaand dalk te vroeg om op te hou...

\subsubsection{KREATIWITEIT IS OOK IETS WAT JY MOET “LEER"}

In hoofstuk 3 het ons gesien dat dit vir predikers van die uiterste belang is om anders na alles om hulle heen te kyk, om soos goeie kunstenaars dieper en fyner en verder as ander waar te neem, om uiteindelik die onsienlike God te sien. In hoofstuk 4 het ons na die bril gekyk waardeur ons moet kyk indien ons hierdie onsienlike God wil sien, naamlik die Skrif. Aan die begin van hierdie hoofstuk het ons mekaar daaraan herinner dat ons oë geopen moet word voordat ons deur die bril kan kyk om die onsienlike God te sien, en dat dit die Gees, en alleen maar die Gees is wat ons oë só kan open.

Onderliggend aan al drie hierdie "visionêre prosesse" is 'n nuwe kreatiwiteit, 'n kreatiwiteit wat as gawe van God aan ons geskenk word, maar waaraan ons as mense met alles tot ons beskikking ook moet meewerk. 'n Mens kry iets soos kreatiewe mense, of eerder: mense wat "van nature" kreatiewer as ander is. Dit is 'n bonus - wat egter deur die Gees geheilig moet word. Die goeie nuus is egter ook: selfs mense wat (reken dat hulle) "onkreatief" is, kan kreatiwiteit aanleer - wat óók deur die Gees geheilig moet word. Kreatiwiteit "gebeur", maar word ook "geleer"! Albei is gawes van die Gees!

Die bedoeling van die volgende opmerkings - wat maar een voorbeeld 
uit die sielkunde van kreatiwiteit is - is om te help met hierdie "leer" van kreatiwiteit in die visionêre prosesse van preekmaak. Dit verwoord in elk geval op klassieke manier beproefde neurologiese waarhede, waarhede wat ons beïnvloed of ons nou daarvan bewus is of nie.

\subsubsection{Die vier fases van kreatiwiteit}

Om te preek, is om te skep, is om kreatief te wees. Om dít te kan doen, is meer nodig as net 'n kennis van die nodige eksegetiese metodes en 'n aanvoeling van die behoeftes van die gemeente. Die prediker moet, op grond van die antieke teks van die Bybel, iets nuuts, iets verrassends, moontlik iets ontstellends sê, op só 'n wyse dat die gemeente dit as 'n passende en aktuele woord vir húlle en húlle tyd hoor.

Hiervoor benodig die prediker kreatiwiteit, moet hy of sy 'n "produk" lewer wat vergelykbaar is met enige wetenskaplike of kunstige ontwerp of skepping. Die algemene "reëls" of beter: sielkunde van die kreatiwiteit, geld, soos ons reeds gesê het, ook die prediker as skeppende persoon.

Manfred Josuttis sluit in hierdie verband by die klassieke neurologiese onderskeiding van die vier fases van die kreatiwiteitsproses aan (vgl. Martindale: 103; ook Erika Landau: 66), wat sonder groot moeite ook op die preekmaakproses van toepassing gemaak kan word, naamlik voorbereiding (preparasie), ontwikkeling (inkubasie), verheldering (illuminasie) en vormgewing (verifikasie).

\subsection{Die eerste fase van die preekmaakproses: voorbereiding (preparasie)}

Tydens hierdie fase word so veel as moontlik en so wyd as moontlik inligting versamel met die oog op die preekgebeure Sondag - byna soos 'n spons wat alles opsuig. Die teks waaroor gepreek gaan word, moet so gou moontlik geïdentifiseer, en alle materiaal wat kan help met die verstaan en aktualisering van dié teks, byeengebring word. Alle insigte oor die gemeente, dit wil sê faktore wat vir húlle verstaan en aktualisering van die spesifieke teks relevant of verhinderend mag wees, word oorweeg.

Hier benodig die prediker 'n soort sensitiwiteit in sy of haar waarneming (vgl. 3.6), en 'n naïwiteit in die interpretasie van hierdie waarneming, dit wil sê 'n openheid vir impulse, sonder om dit al te gou te wil sensureer of kategoriseer of stereotipeer. Hier word aanvaar dat skynbaar onbelangrike uitsprake in die teks of gebeure in die gemeente moontlik 'n deurslaggewende rol in die uiteindelike strukturering van die preek mag speel.

Nie alleen moet jy vra: Wat tref my in dié teks? nie, maar ook: Wat tref my nié?, en: Waarom nie?

Die drang om te onderskei tussen dit wat belangrik is of nie, word teen- 
gestaan. Stereotipes, wat die volle omvang van uitsprake en vraagstellings van die teks en die gemeente voortydig in 'n formule wil vasvang, word doelbewus vermy, eerder gelet op die onverstaanbare, ongewone, onwaarskynlike. Só word 'n breë basis geskep waarop en waaruit die eintlike kreatiewe proses kan spruit. Wie te haastig oor die voorbereidingsfase heen wil snel, kort onvermydelik op kreatiwiteit in. Wie op Maandag al hulle preke wil neerskryf, sal dit dalk op Saterdag weer moet oorskryf!

\subsection{Die tweede fase van die preekmaakproses: ontwikkeling (inkubasie)}

Die oorgang tussen die voorbereidings- en ontwikkelingsfases (soos ook die ander fases) verloop nie noodwendig kronologies nie, maar saaklogies. Die onderskeid tussen dié twee lê moontlik in die feit dat die ontwikkeling - inkubasie - meestal in die onderbewuste afspeel (waar sewe agstes van ons breinfunksies plaasvind), oftewel tydens die beoefening van "unfocussed attention". Die inligting wat tydens die voorbereidingsfase versamel is, word deur die prediker in sy of haar onderbewussyn omgedra en verwerk in die rigting van 'n oplossing. Selfs al is die prediker glad nie daarvan bewus nie, is hy of sy besig met die preek - of dit nou tydens huisbesoek, 'n kerkraadsvergadering of op die gholfbaan is. Een van die noodsaaklike elemente van die preekmakproses is om te gaan slaap - waarvoor sekere predikers natuurlik geen ekstra aanmoediging nodig het nie! Vir dié wat Hy liefhet, gee die Here dit in hulle slaap! (Psalm. 127:2) Rudolf Bohren sou sê: neem die teks saam met jou die nag in, vertrou die teks, dit gaan sy weg met ons; vertrou ook die Gees - Hy is immers ook Heer van ons onderbewussyn...

Waarskuwing: nie alleen kan 'n mens die voorbereidingsfase te lank uitrek, en té oorlaai en gespanne raak om kreatief te wees nie, maar ook die inkubasiefase, om té ontlaai en ontspanne te wees. Wie heeltyd wil slaap, sal nie sonder meer Sondag 'n geniale preek lewer nie. Ek vermoed dat my waarskuwing ook hier waarskynlik meer van toepassing op dié kategorie van predikers sal wees wat 'n natuurlike neiging tot ontlading en ontspanning het...

Kreatiwiteitspsigoloë wys daarop dat hierdie fase, waartydens die versamelde insigte en verskeidenheid van moontlikhede in die onderbewuste rondskommel, vir die individu 'n baie onrustige en frustrerende tyd kan wees. Dikwels gaan dit gepaard met minderwaardigheidsgevoelens, en 'n merkbaar laer irritasievlak. Jy oorweeg kort-kort 'n ander teks om oor te preek. Of om 'n preekbundel te gryp en 'n kitsklaar preek daaruit te haal. Of om iemand anders te kry om te kom preek. Of om die dokter te versoek om jou af te boek. Jy wanhoop selfs aan jou roeping, oorweeg 'n ander beroep. Hou goeie moed: ons skep nie iets nuuts uit 'n vakuum nie, maar 
uit chaos (MW Shelley). En, 'n mens móét chaos in jouself hê om geboorte te kan skenk aan 'n dansende ster! (Nietzsche) Elke goeie preek is blykbaar 'n preek waaroor daar eers gewanhoop is!

Dan word dit tyd om te gaan speel. Hiermee bedoel ek nie net gholf of iets dergliks nie, hoewel ook dít, soos ons reeds gesien het, nie sonder defnitiewe homiletiese waarde is nie! Hier dink ek eerder aan die kreatiewe spel buite, maar veral ook binne die gemeenskap van die gelowiges, 'n spel waarin die vele moontlikhede wat in 'n teks opgesluit lê, met mekaar gedeel word, bevraagteken word, uit verskillende perspektiewe en ervarings teen die lig gehou word.

Hier handel dit nie in die eerste plek daarom om 'n klinkklare "greep" op die teks te kry nie, maar eerder om die genot in die teks, die vreugde in die oordenking daarvan (vgl. Ps. 1:2), ja om die genot en vreugde in God self. Dis immers 'n spel (vgl. 2.6), waarin byna op 'n naïewe wyse met die teks omgegaan word, en eerder gelet word op die eerste belewenisse of reaksies wat die teks by jou en ander oproep, as om dit tot in die fynste besonderhede en kognitief te ontrafel.

Hier handel dit eerder om die gemeentelike ervaring van die teks, as die individuele verklaring van die teks. Prakties beteken dit dat predikers die rondte in hulle gemeentes kan doen, en in gesprekke met lidmate hulle eie onsekerhede en vraagtekens, maar ook insigte en uitroeptekens rondom die teks op die tafel kan lê, in die hoop dat daar 'n tafelgesprek binne die huisgesin van God hieroor kan plaasvind - ten einde die ontwikkelingsperiode te verryk en meer draagbaar te maak. 'n Gemeentelike, kreatiewe spel met die teks is trouens noodsaaklik in al die fases, en omsirkel dit (vgl. die modelle vir 'n preekgespreksgroep in 5.4).

\subsection{Die derde fase van die preekmaakproses: verheldering (illuminasie)}

Hierdie fase word dikwels ingelui deur 'n aha-ervaring, 'n vonk, 'n blits waarin jy dinge sien soos jy dit nog nooit voorheen gesien het nie - "when the plan comes together" (A-Team se leuse). Meestal gebeur dit op 'n spontane wyse, wanneer die versamelde materiaal wat in die ontwikkelingsfase in jou gemoed gewoel het, plotseling bepaalde kontoere begin aanneem, "vaartbelyn" begin raak en "in hulle plek" begin val.

Ek verwys terug na ons aanvanklike definisie van kreatiwiteit: wanneer twee uiteenlopende sake op 'n innoverende, assosiatiewe (of bisosiatiewe) wyse aan mekaar gebind word, om 'n bepaalde, nuwe funksie te vervul. In die prediking bestaan die kreatiewe moment daarin dat ' $n$ innoverende verband tussen die wêreld van die teks en die wêreld van die gemeente gelê word, of beter: ontdek word, met die resultaat dat dit 'n nuwe reaksie of gehoorsaamheid by die gemeente aan die gang sit. 
Skielik word die invalshoek van die teks na die gemeente, of omgekeerd, vir die prediker duidelik, sien hy of sy dit asof vir die eerste keer. Dan gaan die oë oop om die werklikheid van die onsienlike God in terme van die werklikheid van die gemeente waar te neem (vgl. Heb.11:27; ook 3.6). Die verhelderingsfase sou daarom ook 'n visionêre fase genoem kon word, waarin die geestesoë só verhelder word (vgl. Efes. 1:18) om die wêreld, en die gemeente binne hierdie wêreld, deur die bril van dié spesifieke teks te sien (vgl. Hoofstuk 4). Skielik word die visioen gebore, word die bril skoon na God én na die wêreld toe...

Die vraag: Hoe is die God van die teks in die wereld van die gemeente werksaam? word op 'n nuwe wyse beantwoord - of ten minste benader. Tydens die verhelderingsfase word die relevansie van die teks, hetsy in aanknoping by, of in weerspreking van die wêreld, vir die wêreld gesnap. Dit kan in die vorm van 'n vraag van die teks aan die wêreld, of andersom wees, maar sal in elk geval 'n Kristallisationskern (Josuttis), 'n basiese idee, 'n vonk van insig bied hoe om die dialoog tussen teks en werklikheid op 'n nuwe wyse te stimuleer. Dis hier waar die kreatiwiteit "gebeur" (6.8.1).

Hierdie nuwe verband of brug kan, soos reeds gesê, uit 'n ooreenkoms of analogie tussen die wêreld van die teks en die wêreld van die gemeente bestaan, hoewel hiermee met groot versigtigheid omgegaan moet word. Dit gebeur male sonder tal in preke dat daar só naarstig na ooreenkomste gesoek word, dat die vreemde, die weerbarstige van die teks ingekort word. Indikatiewe uitsprake word omgeswaai in paranetiese appèlle, tekste wat vir die volk van God bedoel is, word verindividualiseer, die eskatologiese dimensies word verburgerlik, kortom, die belofteryke struktuur van die teks gaan verlore. Die dialoog of wisselwerking tussen teks en werklikheid word misverstaan as 'n kompromis. Niks kort kreatiwiteit egter so in soos kompromieë nie.

Veeleerder sal kreatiewe prediking daarom soek na die teenstelling tussen teks en werklikheid, na die botsing van belange, ten einde die werklikheid te verander, om dit te buig in die rigting van die wêreld van God waarvan die Bybelteks getuig.

\subsection{Die vierde fase van die preekmaakproses: vormgewing (verifikasie)}

Met bogenoemde word nie gesê dat die antitetiese model die enigste hermeneutiese model is wat daar is nie. Inteendeel, tydens die volgende fase, naamlik dié van vormgewing, word die nuutgevonde verheldering nou getoets en gestruktureer totdat dit bruikbaar vir die prediker en gemeente is.

In 'n sekere sin is dit die moeilikste van al die fases, want nou moet die subjektiewe insig in objektiewe, simboliese vorme (byvoorbeeld in taal) 
uitgedruk word, moet die verheldering op 'n funksionele wyse gekommunikeer word. Nou moet woorde gevind word wat die bevrore meer in die harte van die luisteraars soos yspikke kan stukkend kap (Kafka). Nou moet dít wat jy "gesien" het, só in "woordprente" omgesit word, dat jou luisteraar dit ook kan "sien".

Terwyl die verhelderingsfase daarop gemik is om 'n brug tussen teks en wêreld te vind, moet die vormgewingsfase daartoe lei dat hierdie brug ook nou op só 'n wyse gekonstrueer word, dat die heen en weer verkeer tussen teks en wêreld moontlik gemaak en gedra kan word.

Hoe moet dit gedoen word? Met hierdie vraag het predikers en homilete deur die jare heen geworstel. Die klassieke model sou wees om 'n (redelik stereotiepe) "raamwerk" te hê waarbinne die eksegetiese "boodskap" gegiet word - 'n manier van doen wat dikwels die dinamika van die teks uit die oog verloor en inderdaad laat stol het. Immers, nie alle tekste val uiteen in drie of ses punte nie; nie alle tekste dra die verengde "teologie" van die prediker nie.

Fred Craddock wou juis doelbewus uit hierdie skematisme breek met sy belangwekkende boek As One Without Authority. Daarin pleit hy vir 'n "induktiewe" proses wat beteken dat die preek as 't ware die ontdekkingstog van die prediker met die teks tydens die preek moet laat "herleef", sodat die gemeente ook na hulle asem kan snak, ook die opwindende wendinge van die teks kan naloop, ook aha! kan roep. Die preek moet die gemeente as 't ware op die punte van hulle stoele hou, in afwagting: wat gaan ons volgende hoor? Dit moet verrassingsmomente bevat wat nie voortydig verklap of by voorbaat in 'n skema vasgelê word nie.

Hiermee word nie gesê dat 'n prediker die verwondering op kunsmatige manier moet "struktureer" of "opwerk" tydens die preek en erediens nie, maar dat dié verwondering wat hy of sy self veral tydens die verhelderingsfase ervaar het, op 'n manier deurgedra moet word na die preek en die erediens, lewend gehou moet word tot dan - om daar ook nog vergroot te word! Die preek is nie bloot 'n beskrywing van die verwondering nie, maar 'n belydenis van, en 'n passie vir die verwondering (Kierkegaard) wat in die styl van die prediker bly opval. Die innerlike struktuur van die preek - watter vorm dit ookal aanneem - bly dié van gebed (Bohren).

Eugene Lowry se boek The Homiletical Plot volg weer 'n ander weg. Hy makk heelwat van die paradoksale van die Bybelse boodskap - byna soos bogenoemde antitetiese siening van die teks. Die preek moet doelbewus die ekwilibrium van die hoorders versteur, hulle onrustig stem, of ten minste opwek om vrae te vra wat hulle nie andersins sou vra nie. Beide Craddock en Lowry wil kreatiwiteit en opwinding terugbring in die vormgewing van die preek, wil doelbewus wegbeweeg van 'n statiese "buitelyn" 
en die klem laat val op die ontdekking van die nuutheid en andersheid van die evangelie.

Iets soortgelyks sien 'n mens in die aanpak van David Buttrick in sy boek Homiletic. Hy gebruik die analogie van die kamera en wil aantoon dat die mens se verstand en waarneming ook so werk: As jy iets kan "sien", het dit 'n baie groter uitwerking op jou as blote steriele inligting. Die preek moet dan die een prentjie of foto na die ander aan die gemeente voorhou, sodat hulle aan die einde daarvan kan sê: ek het die volle prentjie gesien. Die een "idee" volg die ander vaartbelyn op - presies soos in 'n goeie film, en nooi die kyker so dié wonderwêreld binne.

In die konstruksieproses van die brug tussen teks en wêreld is dit gelukkig nie net die prediker wat beplan en bou nie, maar het die gemeente, soos ons in hoofstuk 5 gesien het, juis 'n belangrike rol om te speel - ten minste moet daar ruimte wees dat die dominee se preek tydens die dinamiese gebeurtenis van die prediking en erediens óók gevorm kan word, kan groei en ontplooi op 'n verrassende wyse, ook anders as wat die prediker presies beplan het. Ons beste preke "gebeur" nie net (nog nie!) in die studeerkamer nie, maar veral ook op die kansel!

Ten slotte moet juis weer daarop gewys word dat die kreatiewe omgang van die prediker met die teks nie noodwendig 'n kreatiewe preek sal waarborg nie. Die preek is 'n kreatiewe gebeurtenis, waarin die Heilige Gees 'n deurslaggewende rol speel (vgl. 6.6). Die werk van die Gees omsirkel die teks, gemeente en prediker, en al die kreatiewe prosesse wat daarin mag afspeel, en neem dit in sy diens - anders verword ons kreatiwiteit tot 'n blote werktuig van kerklike manipulasie. Die omsluitende werk van die Gees kan moontlik skematies soos volg uitgedruk word:

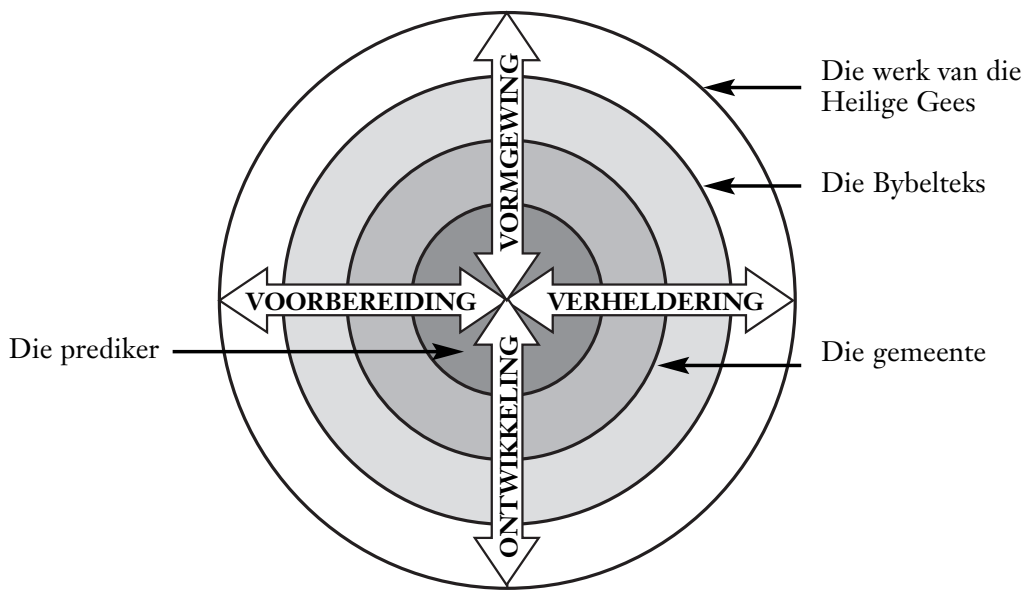


Die Gees omsluit al ons pogings! Dus: wie kreatief wil preek, kán nie anders nie as om te bly roep:

\section{VENI, CREATOR SPIRITUS! \\ KOM, SKEPPER-GEES!}

\subsection{Prediking as ver-beelding}

In die eerste hoofstuk van hierdie boek (1.3) het ons daarop gelet dat 'n kultuur van beelde al hoe meer in ons samelewing begin posvat. Hierdie ontwikkelinge het natuurlik ook nie die prediking onaangeroer gelaat nie. In die homiletiek (preekkunde) tref 'n mens al hoe meer 'n skuif weg van retoriese uitnemendheid na 'n verbeeldingryke18 benadering aan, waarin die klem val op die belang van die beeld, oftewel visuele, en die vermoë om ver-beeldingryk met die Skrif om te gaan (Wallace 1995: 8). Retoriek as die klassieke wyse waarop oorreding moet plaasvind, neem byvoorbeeld nou 'n tweede plek in ná poiesis as die kuns om te skep of te vorm deur woorde.

Hierdie beklemtoning van beelde en verbeelding hang saam met die opkoms van die sogenaamde narratiewe prediking, ${ }^{19}$ waarin dit onder meer gaan om die herwinning van die aard van die Skrif self as die groot Verhaal van God se ontmoeting met die mens, en wat in die proses ook die mens as aangesprokene uiters ernstig wil opneem. 'n Belangrike mylpaal in hierdie ontwikkeling was die bydrae van die homileet Fred Craddock, wat in sy publikasies ${ }^{20}$ die aanvoorwerk vir 'n meer induktiewe benadering tot die preekmaakproses gedoen het. Daarna het 'n stortvloed van boeke en artikels oor die prediking dié nuwe belangstelling uitgedruk: Imaginal Preaching (Wallace 1995); Imagining a sermon (Troeger 1990); ook Creating fresh images for preaching (1982), en Homiletics as imaginative theology (1987); Preaching as re-imagination (Brueggemann 1995); Imagination of the beart: New understandings in preaching (Wilson 1988); Imaginative Shock. Preaching and Metaphor (Riegert 1990) om maar enkeles as aptytwekkers te noem.

Die klem op beelde moet in die prediking nie as 'n nuwe, enkelvoudige

18 Die term verbeelding (imagination) het 'n ryke geskiedenis, en kan inderdaad uit 'n verskeidenheid van perspektiewe en wetenskaplike dissiplines beskrywe word. Vir 'n uitstekende voorbeeld, vgl. Ross-Bryant 1981: Imagination and the life of the Spirit.

19 Vir'n goeie oriëntering, vgl. Lowry 1980: The homiletical plot: the sermon as Narrative art form.

20 Die belangrikstes is: As one without authority (1971); Overhearing the gospel (1978) en Preaching (1985). 
resep verstaan word nie. Wat ek dus in hierdie verband wil sê, is hoogstens 'n perspektief, in 'n sekere sin 'n eksperiment, wat nie op sy eie kan staan nie, maar altyd in samehang met ander preekmodi beoefen moet word. Die riglyne wat ek voorstel (vgl. punt 6.9.4), dien bloot as suggesties wat om kritiese en kreatiewe evaluering vra. Ter wille van duidelikheid onderskei ek ook tussen ten minste vier vlakke waarop die uidrukking "beeld" kan funksioneer:

- As onuitgesproke, en dus nie-verbale voorstellinge wat in die menslike brein voorkom. Die (nag én dag!) drome wat ons droom sou hieronder verstaan kon word. Sommige psigoloë verwys in dié verband na argetipiese droomstrukture, as 't ware primordiale inprentinge waarin die menslike eksistensie verdig word, en wat te make het met geboorte, lewe, seksualiteit, angs, skaamte, dood, ens. (die argetipiese psigoloog James Hillman (1979:108) noem dit "the soul's language").

- Beelde wat in taal geverbaliseer word. Hieronder val 'n hele spektrum van grammatikale moontlikhede, soos allegorie (sinnebeeldige voorstelling van 'n abstrakte begrip); vergelyking (stylfiguur waarin twee dinge met mekaar vergelyk word, gewoonlik met gebruikmaking van die woordjie soos); gelykenis (sinnebeeldige verhaal uit die daaglikse lewe, veral om 'n godsdienstige waarheid tuis te bring, byvoorbeeld wanneer Jesus sê: Die koninkryk van God is soos...); metafoor (oodragtelike uitdrukking wat op 'n vergelyking berus), ens.

- Visuele beelde - soos dié waarvan ons samelewing (televisie, rekenaar, filmbedryf, ens.) vól is, en wat daarop gemik is om 'n sekere reaksie by mense te ontlok.

- Beelde wat in tekste, en in die besonder in Bybelse tekste, opgesluit lê. My uitgangspunt is dat daar sekere basiese beelde in die Bybelse teks gegee is, waarsonder ons as mense nie kan lewe nie, beelde van onsself, van God, van ons wêreld; beelde wat uiteraard ook taalmatig uitgedruk moet word, in die vorm van metafore, gelykenisse, ens.

Die samelewing se skarniere draai op beelde. Ons mag na my mening ook in die prediking nie hieraan verbygaan nie. Die ontwikkeling van die prediking as ' $n$ ver-beeldingsproses moet egter op 'n gebalanseerde wyse plaasvind, en wel met die volgende in gedagte:

\subsubsection{BREIN EN BEELD: 'N NEUROKOGNITIEWE INTEGRASIE}

Om "beeldend te dink" is niks nuuts nie - dis 'n neurologiese gegewe. Ons moet egter versigtig wees om nie eensydig oor hierdie funksie van die 
brein te dink nie. Neuroloë identifiseer nie minder nie as agt ${ }^{21}$ neurokognitiewe sisteme wat saam moet werk om die brein optimaal te laat funksioneer. Du Preez (1991:27) stel hierdie neurokognitiewe model van integrasie skematies soos volg voor:

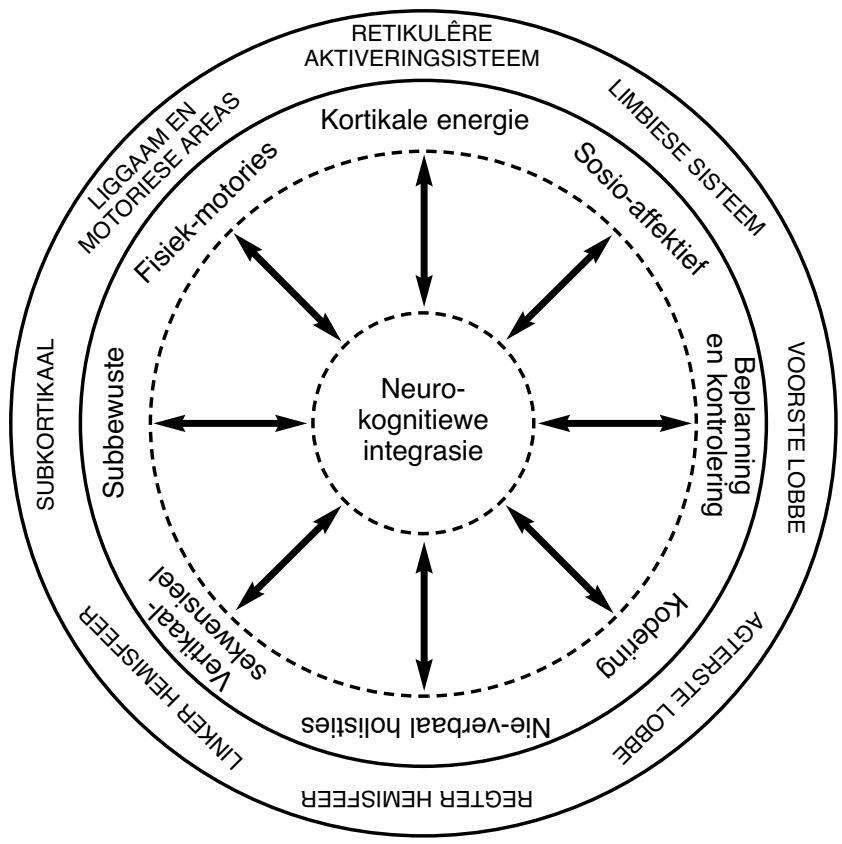

Die onderskeiding tussen sogenaamde "linkerbrein" en "regterbrein" mense is dus simplisties, en selfs kunsmatig. Wat ons hoogstens kan sê, is dat die regterhemisfeer van die brein (wat met beeld en verbeelding te make het) beter tot sy reg kan kom as dit ondersteun word deur die ander neurokognitiewe sisteme, en dat dit waarskynlik ook' $n$ area is wat baie beter in die kommunikasieproses (en dus prediking) benut beboort te word.

Die regterhemisfeer funksioneer nie-verbaal, visueel-ruimtelik, musikaal, taalprosodies en geheelsienend (holisties) van aard. Om kommunikasie-inhoude byvoorbeeld visueel te verbeeld, kan kognitiewe prosessering in sy geheel bevorder. Of anders gesê: die verbaal-sekwensiële sisteem van die brein, oftewel linkerhemisfeer, kan deur visuele ondersteuning beter in die regterhemisfeer, en dus totale breinfunksie geïntegreer word.

21 Kortikale energie, kodering, beplanning en kontrolering, verbaal-sekwensiële, nie-verbaal-holistiese, fisiek-motoriese, sosio-affektiewe en die subbewuste. Vgl. Du Preez 1991:26. 
Woorde wat beelde dra, kommunikeer byvoorbeeld oneindig beter as woorde wat bloot (abstrakte) konsepte op 'n logies-analitiese wyse aaneenryg. Daar is 'n hemelsbreë verskil tussen die uitspraak: "'n Mens belp jou vriend op só 'n manier dat jy hom/haar nie in gevaar stel nie", en die beeldspraak of metafoor: "'n Mens verwyder nie 'n vlieg met 'n voorhamer van jou vriend se neus nie." Die een hoor jy, maar die ander een "sien" jy!

Baie preke word só gepreek, dat jy inderdaad niks kan sien nie - nie van God nie, en ook nie van jouself of jou medemens nie 22 . Nêrens word vensters op, of vanuit die beelde van die Skrif oopgemaak nie. Nêrens word 'n bietjie lig ingelaat nie. Nie eers 'n sliert wat jou nuuskierig nader wil laat staan om dieper te kyk nie. Soos in 'n preek oor Psalm 62: 2 (Net by God vind ek rus). 'n Paragraaf daaruit lui só:

"Om te wil rus, is 'n wesenlik menslike behoefte. As dit nie gebeur nie, word ons in ons diepste kern aangetas. Sonder rus word ons in 'n eksistensiële krisis gedompel. 'n Mens sou trouens die bele menslike geskiedenis kon beskryf as 'n poging om uit die onrus tot die rus te beweeg. Rus is 'n toestand van stilwees, van ononderbroke geluk, van tevredenheid. Rus is om rustig te wees ten spyte van omstandighede. Rus is 'n ander woord vir geloof, en geloof ken geen spanning en onsekerbeid nie. Om te rus, is om te glo dat God regeer."

Behalwe vir die wrede - en teologies valse - beskrywing van geloof as iets wat "geen spanning en onsekerheid" ken nie, praat die prediker in algemene terme, dit wil sê sonder eksistensiële (sy eie woord!) "aanhakpunte". Die hoorder moet tereg kom êrens tussen 'n vae "wesenlik menslike behoefte", 'n "eksistensiële krisis", die "hele menslike geskiedenis", 'n "toestand van stilwees", en "geloof". Die hoorder verdrink in die baie woordesonder-insigte. Die gepraat oor die rus maak jou moeg, of dompel jou ten minste in die skuld, met die vraag: waarom is ek dan so (onmenslik) onrustig? Nêrens in die preek word die geheim van die "om te" verklaar nie. 'n Paragraaf uit 'n ander preek dui egter op 'n ander styl:

"Wie van ons het nie 'n behoefte aan rus nie? Wie van ons smag nie om tog net vir 'n oomblik te kan ontspan, te kan asembaal, in ons gejaagde samelewing 'n slag jou skoene uit te kan skop en tot jou sinne te kan kom nie? Stilte, ag, ek sou my koninkryk kon prysgee net vir 'n bietjie stilte!

Wel, nou weet ons mos ook dat daar stilte én stilte is. Miskien bet jy die

22 Vir 'n uitgebreide bespreking van die verband tussen sien en prediking, vgl. Cilliers 1998: 31-56; ook Müller 2002:209; die ou Nederlandse boek Vensters in de preek (1968), bly ook steeds 'n interessante werk in dié verband; vgl. ook weer hoofstuk 3 van hierdie boek. 
afgelope vakansie langs die see met sonsondergang gesit en gesien hoedat die son haar laaste knipoog vir jou gee voordat sy onder die water gaan slaap, en in jou was daar 'n salige vrede. Of miskien bet jy al die onbeskryflike stilte ervaar as jy die laaste keer deur die huis loop waarin jy vir tien of twintig jaar gewoon het, en die meubelwa is al weg en die leë vertrekke fluister die somtotaal van ervaringe wat hier afgespeel bet aan jou terug, en jy besef: daar is ' $n$ tyd om te kom, en 'n tyd om te gaan... Of die vreemde stilte wat 'n mens soms in 'n begraafplaas beleef, wanneer die gekoer van die duiwe die stilte nog verdiep en jy weet: ons jare skiet verby soos 'n gedagte... ons vlieg na ons einde toe (Ps. 90:9,10)."

Die kanse dat preek no 2 al die sintuie, of ten minste 'n aantal daarvan sal opvorder (neurologies gesproke: soveel as moontlik van die neurokognitiewe sentra sal stimuleer), en dus begrip sal bevorder, is tog sekerlik beduidend hoër as in die geval van preek no $1 \ldots$ ?

\subsubsection{DiE BYBEL AS BEELDE-BOEK}

Daar is egter 'n nóg fundamenteler rede waarom ons ver-beeldend moet en mag preek. Die Bybel self bestaan naamlik nie bloot uit 'n aaneenryging van woorde, soos pêrels op 'n stringetjie nie. Dit vertel eerder die verhaal van God se bemoeienis met die mens, van sy groot dade in die geskiedenis (vgl. Hand. 2:11), dade wat taalmatig uitgebeeld word (vgl. ook weer hoofstuk 4). Die Bybel is ons oer-bron van beelde - hierheen moet ons telkens maar weer terugkeer indien ons verbeeldingryke teoloë en predikers wil bly. Garrett Green (1989:106) wys in sy klassieke werk op hierdie belang van die Skrif: "God has im-pressed his image, embodied in Fesus Christ, on the original witnesses, who have in turn ex-pressed that image in certain texts; these writings, which we therefore call sacred, once more im-press their form on us, the modern bearers, reshaping us in the image of God... Revelation is an act of imagination; scripture is a work of imagination; and theology is an interpretation of imagination."

In die Bybelse tekste sit daar inderdaad 'n rykdom van beelde of metafore opgesluit, beelde wat mense in hulle diepste nood skilder, maar ook God metafories uit-beeld. Die taak van die prediking is na my mening onder meer om hierdie lewensnoodsaaklike, en lewensveranderende beelde te herwin, en te vertaal, of eerder: te ver-beeld vir die mense van ons tyd. Om te midde van die sensoriese oorprogrammering mense voor die éintlike metafore, die beelde wat saak maak, te bring. Om hulle aan die hand van die teks vir 'n begeleide toer deur die kunsgalery van die Lewe te neem!

Die Bybel is nie bloot 'n Boek wat historiese feite as bruta facta ver- 
kondig nie. Eerder beelde en ver-beeldinge van hierdie feite, beliggaam in woord én beeld. Hierdie beelde moet voortdurend besoek word, hernuwe word, anders bly dit gefikseer in die Skrif. Ons taak as predikers is om verbeeldingryk met die beelde van die Skrif om te gaan, om telkens, en opnuut, soos Jesus self te sê: Die koninkryk van God is soos...!

Agter hierdie soos sit daar 'n werklikheid wat die beeld of metafoor wat volg, altyd oortref ${ }^{23}$. Terwyl die Bybel wel aan ons die eerste, en primêre ver-beelding van die heilshandelinge van God bied, en ons dus telkens daarheen moet terugkeer, is die bedoeling tog nie dat ons die beelde daarin moet fossilieer nie. Die beelde het voortskreidende krag, dit roep om kreatiewe, en dus eietydse, ver-beelding. Beelde kán egter dormant of uitgeslyt word. Dan verloor dit hulle seggingskrag, hulle verbeeldingryke werking. As beelde eers verduidelik moet word, is dit gewoonlik 'n teken dat hulle nie meer as beelde funksioneer nie (vgl. Riegert 1990:73-74). Trouens, beelde wat stol, loop gevaar om valse profesie te word, monumente van 'n teologie-wat-te-laat-gekom-het. Beelde kán idole word. Uitbeeldinge kán onder die tweede gebod sneuwel: $7 y$ mag nie vir jou 'n beeld of enige afbeelding maak nie... (Eks. 20:4)

Dit maak van verbeeldingryke prediking so 'n riskante aangeleentheid! Neurologiese integrasie kan help, maar dit kan nooit die werk van die Gees vervang nie. Die Gees maak ons sensitief vir die tyd waarin ons leef, vir die onderliggende beelde, die ikone wat ons dikwels in hulle ystergreep wil hou, en Hy leer ons telkens hoe om die Bybelse beelde in, en teenoor hierdie ikone te ver-beeld.

Daarom neem die Gees ons ook keer op keer terug na die Skrif, waar ons sy "eerste" verbeeldingryke hermeneutiek kan naloop. Om eietyds te kan ver-beeld, moet ons opnuut in die verbeeldingryke wêreld van die teks ingelei word. Anders verbeel ons ons verkeerde dinge. Dit bly na my mening ' $n$ basiese uitgangspunt: die Bybel bevat beelde wat die inherente $\mathrm{krag}$ het om ons die toekoms in te neem - só, dat ons die ou-ou tyding, die evangelie verbeeldend in elke nuwe tyd kan verkondig. (Wallace 1995:10) skryf mooi: "Images such as the garden, the new beaven and earth, the banquet, bread and wine, oil poured over the head, tears washing feet, fire from above, a newborn infant, and a crucified figure are only some of the ones that continue to throb with numinous power. The task of the preacher is to recover and renew them

23 Teologiese taal en die metafoor loop natuurlik al 'n lang pad saam. Janet Soskice (1985:148) skryf soos volg oor die voordele wat die gebruik van metaforiese taal juis vir die religie inhou: "Our concern is with conceptual possibility rather than proof, and with a demonstration that we may justly claim to speak of God without claiming to define Him, and to do so by means of metaphor. Realism accomodates figurative speech which is reality depicting without claiming to be directly descriptive." 
for the present generation and those to come, so that they are not lost in the mindless haze of imagery substituted by modern technology. Images will continue to be cast and sown into the field of human consciousness; the issue is which of them will take root and flower."

Die Bybel bevat talle sulke basiese beelde, beelde waarmee 'n mens kan leef en sterf, waarin ons opnuut ons eie gesig, maar veral ook dié van God, weerspieël kan sien. 'n Mens dink aan Luther wat telkens van een van hierdie primêre geloofsbeelde kon sê: "Of ek wil of nie, altyd wanneer ek die naam Christus hoor, sien ek in my hart die beeld van die man aan die kruis." (Vgl. Milk s.j: 62)

Geen wonder hy kon so verbeeldingryk oor Christus preek nie!

Luther het ook gesê dat die kerk 'n mond-huis ("Mundhaus"; vgl. 6.1) is. Dit sou egter verkeerd wees om hierdie uitspraak van hom eensydig te verklaar, asof die kerk se verstaan van die Bybel en prediking slegs verbaal, en daarby ook nog kognitief, verstaan moet word. Die Woord - waarvan die Skrif getuig - bestaan immers nie net uit woorde nie, en beslis nie net uit konsepte nie. Ons siening van die Woord is waarskynlik sterk GrieksHellenisties gekleur, met 'n voorkeur vir retoriese logika. Ons maak ons maklik skuldig aan 'n ver-saakliking, 'n ver-dingliking, in plaas van 'n verbeelding van die teks. Die Hebreeuse verstaan van dabár bring ons nader aan die waarheid: die Woord is tegelykertyd ook daad, dis altyd 'n Woordgebeure. Die Woord is nie iets wat ons bloot moet analiseer om dit linguisties te kan ontrafel nie, maar 'n wêreld waarin ons genooi word, 'n Woordwêreld waarbinne óns verander word.

Die Woord het in-der-daad mens geword (Joh. 1:14), en is as sodanig verbaal én nie-verbaal. Dit sou verkeerd wees om die verbale bloot te sien as iets onliggaamliks, en die nie-verbale as iets liggaamliks (Lukken 1990:21) Nee, ook die Woord is liggaamlik, oftewel visueel en ver-beeld. Wie dus oor hierdie Woord wil preek, kán dit nie bloot met 'n aaneenryging van woorde doen, en dink dat die visuele en ligaamlike, ja, die presensie van die een wat preek, nie ook 'n lyflike basis aan die Woord bied, of behoort te bied nie. Die Woord - soos dit opgeteken is in die Skrif roep om 'n holistiese uitbeelding in die verbale én nie-verbale, wil inderdaad telkens onder ons méns word.

In die simboliek word daar soms ook in dié verband tussen 'n presentatiewe en 'n diskursiewe simboliek onderskei. Tiperend van die presentatiewe simboliek is die verdigting van betekenis in 'n simbool, van 'n gelyktydigheid en 'n totaalwaarneming (Lukken 1990:31-32). Een beeld - of dit nou 'n visuele voorstelling of 'n metafoor, dit wil sê 'n voorstelling-inwoorde is - kan 'n hele reeks herinneringe of emosies in 'n oomblik oproep. Wie byvoorbeeld afkom op 'n foto van 'n gelade gebeurtenis of periode in jou lewe, lank-lank gelede, "sien" dinge wat nie noodwendig in 
'n logiese sekwensie van woorde uitgedruk kan word nie Dalk word jou hele lewe in daardie foto verdig en gepresenteer. Dit spreek moontlik al jou sintuie aan: die reuk in Ma se kombuis met die AGA-stoof (dit verraai sommer ook die skrywer se ouderdom!), die tekstuur van $\mathrm{Pa}$ se pet, die herinnering aan die klank van jou broer se voetstappe in die lang gang van jou ouerhuis.

In die diskursiewe simboliek word daarenteen veral taal ingespan om verskillende betekeniseenhede logies op mekaar te laat volg. Ek is van mening dat albei hierdie vorme van simboliek, oftewel verbeelding, van belang is vir die kommunikasie in die prediking, dat die een ingebed in die ander moet lê. Op die vind van hierdie balans, kom dit aan wanneer ons op 'n verantwoordelike wyse vir die mense van ons tyd - wat deur beelde van alle kante gebombardeer word - wil preek. Miskien moet ons hier weer soos die kinders word: hulle eerste persepsies en dus beelde vorm die basis waarop hulle verbale vermoëns ontwikkel. Of meer geïntegreerd gesê: hulle kan Ma se stem nie losdink van haar gesig nie. Kan ons God se stem (Woord) losdink van sy gesig?

Die Woord het vlees geword, en die Skrif getuig daarvan. Die Bybel bevat die verhaal van die beliggaming van die Woord, van die uit-beelding daarvan. Daarom is die Bybel beeldryk, praat dit 'n "highly imaginal language" (Wallace 1995:9). Die woorde in die Bybel skilder prente; dit praat prentetaal. Vir hierdie Boek, wat die oorkonde, dit wil sê die oer-bron van die Naam van God is (Bohren 1971:109), moet ons respek hê: daarin lê die beelde wat deur die eeue heen vir ons bewaar is, en wat wag om op 'n kreatiewe wyse ontgin en opnuut losgelaat te word. Daar skuil engele in die woorde van die Skrif, engele wat onder meer ook in die prediking vlerke kan ontvang om nuut te vlieg. Helaas kortwiek vele preke hierdie engele; knip dit voortydig die vlerke van verbeelding kort.

Dalk vind ons die arbeid aan die teks te hard. Dalk vind ons die téks te hard. Dalk is ons nie bereid om soos Michelangelo met ons (eksegetiese en hermeneutiese) hamertjies en byteltjies aan die rots van die teks te bly kap nie, omdat ons nie - soos hy - gló dat ons 'n engel uit die klip kan bevry nie...

Wie engele in die woorde van die Skrif verwag, kom nie sonder verwagting by die teks aan nie. Die Bybel as beelde-Boek vra 'n spesifieke soort benadering, 'n styl van lees, van eksegese, en uiteindelik prediking. Die prediking is 'n avontuur in 'n dubbele sin: om te soek na die dominante beeld in 'n spesifieke teks, én om dit ver-beeldend te vertaal, ja, te vertel vir die mense van ons tyd. Wallace (1995:18) skryf: "Imaginal preaching calls for a particular way of approaching our task. Rather than looking for the main idea, the key thought, we search for the dominant image in the story, the letter, the prophetic word, that image which will control all that we say, that will serve 
thought, feeling and motivation. Imaginal preaching also calls us to attend to the images that we are given by life and by the faith tradition we serve; but it is most important that we first look and listen attentively to those found in the primary sources for preaching, the biblical texts."

Ons benader dus die Skrif met die oog op die basiese beelde, kan ek maar sê die beelde van die evangelie, om hulle in verband te bring met die beelde van ons samelewing, van die wêreld waarin ons ons bevind. Hierin lê die kreatiewe spanning van die prediking, in die vraag: wat sal gebeur as hierdie Skrifbeeld, hierdie dominante "prent" van die teks - of dit nou 'n karakter, 'n moment in 'n verhaal of 'n sleutelmetafoor is - 'n ontmoeting met hierdie of daardie aspek van ons lewens sou hê? Wat sou gebeur as die éintlike beelde van die lewe as kontra-beelde in konfrontasie kom met die stortvloed van idole wat ons lewens wil vul? Deur watter beelde laat ons ons werklikbede vorm?

Kortom: predikers is tussengangers tussen die metafore van die Skrif en die metafore van ons elkedagse werklikhede, op soek na aanhakpunte, na versterking van die goeie metafore van die lewe, maar ook sensitief daarvoor dat die metafoor van die evangelie nie vervlak mag word tot die minder goeie, en selfs bose metafore wat ons omring nie. Predikers is mense wat in die wêrelde van die teks én die lewe moet inklim, ten einde die dominante beelde in albei werklik raak te sien en te verstaan. Wat 'n asemrowende gedagte: predikers beweeg heen en weer oor die brug tussen teks en lewe, as mediatiors en bewaarders van beelde en metafore - ook dié van die evangelie!

\subsubsection{DIE WERKING VAN BEELDE...}

Daar sit iets geheimnisvol in die werking van beelde, iets wat inderdaad nie onder woorde gebring kán of moet word nie. Die volgende is na my mening wel van belang vir ons onderwerp:

- Die verhouding tussen beeld en seggenskrag. Beelde dien woorde, of beter: bring dimensies van woorde na vore wat andersins ongesiens verby sou gegaan het. In 'n sin vertraag beelde die (vinnige, dikwels onnadenkende) vloei van woorde, ten einde dit te verryk. Beelde help ons om van "thin" na "thick descriptions of reality" in ons kommunikasieprosesse te beweeg (vgl. Brueggemann 1997:73 e.v.). Woorde alleen kan baie skraal en klinies wees. Beelde, daarenteen, verander ons (modernistiese) neiging tot digitale kommunikasie tot analogiese kommunikasie, mak vensters op die werklikheid oop wat woorde alleen nie sou kon doen nie. 'n Interressante voorbeeld is die gebruik van beelde deur digters soos byvoorbeeld Sheila Cussons. By haar is daar blykbaar 'n voort- 
durende spel tussen beeld en woord aanwesig. ${ }^{24}$ Soms skilder sy letterlik eers 'n beeld uit haar gemoed op doek, voordat sy dit omsit in die woorde van 'n gedig. Soms loop die twee prosesse gelyktydig, word skilderkuns en digkuns in één kreatiewe fase vermeng. Soms maak Cussons eers nádat sy die gedig geskryf het, 'n skildery of uitbeelding daarvan. As haar vriende haar by geleentheid skakel om te vra wat sy doen, antwoord sy: "Ek dink". Sy weet uit ervaring dat kreatiwiteit tyd nodig het. Dat dit lank kan duur vir die engel om deur jou kop te gaan, soos die titel van haar digbundel ('n Engel deur my kop: 1997) sê.

- Beelde ver-beeld die werklikheid. Dit gebeur soos volg: eers is daar 'n moment van oriëntasie, waarin jy sekere bekende dinge in die beeld herken: die beeld spreek iets van jou werklikheid aan. Dan volg die fase (nie noodwendig sekwensieël nie; meestal gelyktydig) van disoriëntasie, wanneer die beeld jou werklikheid bevraagteken, en in 'n sin omvergooi. Die beelde van die Bybel werk meestal só: 'n bekende metafoor word skielik uitdagend, werk subversief op die status quo in. Die klein stukkie suurdeeg word beeld van 'n onstuitbare koninkryk (Matt. 13:33)! Die beelde van die Skrif is inderdaad dikwels kontrabeelde, beelde wat 'n "imaginative shock" op ons bewerkstellig, wat as 'n "counter-as" die andersoortige "soos" van die koninkryk aan ons voorhou (vgl. Riegert 1990:72-74; ook Brueggemann 1993:15). Ná die disoriëntasie volg 'n fase van beroriëntasie, waarin die beeld die vooruitsigte van nuwe moontlikhede en wêrelde aan ons open, en inderdaad as wêreldskeppende kragte funksioneer. Die Bybelse beelde is soos vingers wat in die rigting van God se alternatief wys, en naderwink...

- Beelde bly egter bloot fragmente. Dit beeld slegs 'n onderdeel van die geheel - in hierdie geval van die koninkryk - uit. Bybelse tekste is stukkies legkaart in die groot beeld. Dit bied aan ons snitte, weliswaar dinamiese, polsende snitte, maar net snitte van die groter prent. Dis hoogstens ' $n$ af-beeld van die oer-beeld of beter: eind-beeld. Beelde is ons beste poging om die onsienlike af te beeld. Dit bly egter voorlopig: Nou kyk ons nog in 'n dowwe spieël en sien 'n raaiselagtige beeld, maar eendag sal ons alles sien soos dit werklik is (1 Kor. 13:12).

24 Soos blyk uit 'n voordrag van Amanda Botha, besoekende kuratrise van die SasolKunsmuseum op Stellenbosch, tydens die jaarlikse Woordfees (27 Februarie 2002), met die bekendstelling van sommige van Sheila Cussons se kunswerke. Ook saamgevat in Die Burger van 4 Maart 2002, p 4: "Vir haar (Cussons) staan beeld en woord altyd in wisselwerking met mekaar. Skilderye word gedigte, gedigte word skilderye - letterlik en figuurlik. Haar lewe is verdeel tussen tekeninge en gedigte - vir baar is dit net belangrik om te werk." 


\subsubsection{PREDIKING AS VER-BEELDING: ENKELE RIGLYNE}

Ek stip kortliks enkele riglyne vir die ontginning en gebruik van beelde in die prediking aan:

- Werk hard aan die teks; bly hammer en beitel daaraan. Om die dominante beeld in die teks te vind, vra inderdaad 'n volgehoue ontmoeting daarmee, 'n noulettende (historiese, eksegetiese en hermeneutiese) toewyding daaraan, maar nie bloot om kognitiewe informasie of bruta facta of 'n vae "tema" daaruit te distilleer nie; eerder om die bui en die beweging ("mood and movement"; vgl. Buttrick 1987:294 e.v.) daarvan te ervaar. In 'n sekere sin sou 'n mens die regte soort musiek moes kon uitkies om die bui van die teks te verklank! Sou die woorde van diégene wat oor Psalm 150 wou preek, nie iets van die "atmosfeer" van Händel se Halleluja-koor moes adem nie? Maar dan sou jy eers saam met sy $\mathrm{He}$ was despised oor die Lydende Kneg (Jes. 53) moes lamenteer...?

- Moet die beeld nie probeer verduidelik nie! Dis tipies van die modernisme om alles tot op die been toe te wil verklaar, om alle misterie te wil uit-praat, en in werklikheid dan ook dood te praat. Moet die beeld nie in 'n konsep verander nie. Moet die werking daarvan nie kognitief probeer ontrafel deur dit saam te vat, op te som, en dán nogal "toe te pas" nie. Laat die beeld sy eie loop neem, en so sy "seggingskrag" verbreed. Tekste is immers nie gerig op die blote oordrag van informasie nie, maar op performansie: dit het 'n intensie, 'n doel, naamlik om mense te verander. Laat die beeld dus toe om self sy boodskap oor te dra. Onthou: die beeld is nie net die draer van 'n boodskap nie, dit is in 'n bepaalde sin sélf die boodskap. "The medium is the message" (Marshall MacLuhan). Dis 'n algemeen geldende reël in die wêreld van die kommunikasiewetenskap, en in die prediking nie minder nie.

- Bekyk die beeld vanuit verskillende perspektiewe; draai dit na alle kante toe soos 'n diamant, om die veelkantigheid daarvan beter te kan waardeer. Word een van die karakters in die verhaal om telkens daarna vanuit ' $n$ ander hoek te kan kyk. Dit beteken egter nie dat ons die beeld moet verkompliseer nie: dit moet steeds een-voudig bly, en 'n beperkte kode hê, wat deur volwassenes én kinders ontsluit sou kon word (vgl. Lukken 1990:33). Hierin lê waarskynlik die krag van die beeld: dit kan 'n hoogs intellektuele persoon, sowel as 'n kind op maniere aanspreek wat woorde alleen nie kan doen nie. Dit kan dinge sê wat te diep en te wonderlik vir woorde is.

- Giet die beeld in 'n bepaalde vorm. Hierin lê na my mening een van die moeilikste opdragte vir die prediking: om die primêre beeld van die Skrif in 'n vorm te ver-beeld wat die mense van ons tyd die beste sal verstaan - sonder dat 
die wese van hierdie primêre beeld in die proses verlore gaan. Dis hier waar ons moet ligloop om nie die beelde van die Skrif te ver-plastiseer, en die kuns van die Skrif met homiletiese en liturgiese kitsch te bederf nie (vgl. Wepener en Müller, 2001:480-493). Die grens tussen kuns en kitsch, tussen estetika en kommersialisering, is inderdaad dun. Hier kom die vermoë, die gawe om met integriteit te kan ver-beeld, en te hér-verbeeld, ter sprake. Hier kan die wêrelde van die drama en kuns, maar ook van die literatuur, ons oneindig baie help. Die primêre beelde van die Skrif kan op meer as een manier ver-beeld word: in visuele voorstellings, in die hele spektrum van die nie-verbale, dalk in stiltes, en natuurlik ook in woorde - met die hoop dat die mens in al sy of haar sintuie geraak word. Dis daarom belangrik om die primêre beeld van die Skrif nie te sien as 'n stilstaande prent, soos 'n stillewe (statiese droërangskikking!) nie, maar eerder as 'n toneel in 'n (heils) drama, waarin die prediker én die hoorders ingetrek word om deel van die Groot Verhaal te word, maar ook as 'n toneel met atmosfeer ("mood"), wat binne-in my moet kom. Sodat ons inderdaad saam met Luther kan sê: "Of ek wil of nie, altyd wanneer ek die naam Christus hoor, sien ek in my bart die beeld van die man aan die kruis."

\subsection{Preekvoorbeelde van die mislukte (moralistiese) funksionering van predikers}

Daar is min plekke waar 'n mens so bewus daarvan is dat jy maar net 'n ou mannetjie - of vroutjie - is, verrese uit die stof, as op die kansel (Calvyn). En tog word diegene wat dit daar wáág nie om dowe neute Verbi divini minister, bedienaar van die Goddelike Woord, genoem nie. Hulle het 'n spesifieke opdrag en 'n spesifieke gesag ontvang, 'n opdrag en gesag wat op geen wyse terugherlei kan word na enige potensiaal of verdienste wat gebore word uit hulle stofbestaan nie. Hulle is bedienaars van 'n ander verdienste, naamlik dié van Christus.

Die opdrag en die gesag van alle predikers van die Woord staan en val met die verkondiging van die evangelie. Hulle word geroep nie om blote mededelings oor die heil te maak nie, maar eerder mededelings van die heil. Wie preek, in elk geval in die Reformatoriese sin van die Woord, dring nie aan op die verdienste van mense nie, maar bedien die genade van God aan hulle. In wettiese preke gebeur juis dit nié. Die volgorde word, al geskied dit in 'n veelheid van nuanses, presies omgekeer: die genade word onder die voorwaarde van die potensiaal en die handelinge van die godsdienstige mens (homo religiosus) geplaas en in werklikheid uitgerangeer. Die vrae wat hier na vore dring is: Watter rol speel die prediker in hierdie omke- 
ringsproses? Watter posisie neem hy of sy in? Watter tipiese kenmerke kan uit die analise van moralistiese preke afgelei word?

\subsection{1 'N VERSKUIWING VAN DIE GESAGSBASIS}

Die eerste wat in die oog spring, is die subtiele verskuiwing van die gesagsbasis weg van die teks en God af, na die persoon van die prediker. Die prediker begin doen wat net die Woord en God kan doen, begin weet wat net God kan weet. In 'n besonderse flagrante voorbeeld hiervan hoor ons sinne soos die volgende:

"Ek nooi jou uit om toe te laat dat die Heilige Gees vanmôre jou denke
verander."

Wie inisieer hier die heil? Die Heilige Gees? Die prediker? Die luisteraar? Wie is hier die agent wat alles waarvan die preek praat, waar moet maak? Insiggewend is ook 'n sin soos die volgende:

\section{"Vanmôre wil die Here hê dat jy ook op 'n sekere manier oor die lewe moet dink."}

Dit tref 'n mens nogal dikwels in wettiese preke aan: predikers wat blykbaar presies weet, nie net wat die hoorders wil of doen nie, maar veral ook wat die Here wil en inderdaad in die preek doen:

"Daarom praat die Here ook vanmôre met jou om te sê... Dit is God, wat op bierdie oomblik op 'n bonatuurlike wyse jou bewus maak van sy bemoeienis met jou... Terwyl jy na my luister, is jy bewus daarvan dat God met jou praat. Dit is omdat Hy deur sy Heilige Gees nou met jou bemoeienis maak."

In die slotgebed van die erediens verwoord die prediker sy absolute sekerheid oor die gedagtes van mense en die werke van God só:

"Maar terwyl ek die Woord bedien was daar mense wat gesê het ek hunker daarna. Dankie Here, dat $U$ deur die Heilige Gees reeds verandering bewerkstellig het, dat die mense reeds in bulle denke vernuwe bet. Maar baie dankie dat U nou ook op 'n bonatuurlike wyse bulle gemoedstoestand verander en dat bulle besef God het bulle nuut gemaak... Dankie Here, dat U ook bulle wat in krisis is in bierdie môre bedien het. Dankie dat $U$ bulle wat in nood is vanmôre gehelp bet, alhoewel bulle omstandigheid nog dieselfde is, is bulle gemoedstoestand anders, omdat U bulle denke vernuwe bet." 
'n Mens sou sekerlik kon aanvaar dat dit alles dinge is wat die prediker graag sou wou sien gebeur, so graag dat hy selfs 'n tipe profetiese perfectum daarvoor gebruik. Dis egter 'n vraag of dit alles in werklikheid so ís of so gebeur soos die prediker dit uitspreek.

'n Mens hoor dieselfde tendens in 'n ander preek:

"Ons staan aan die einde van 'n uitreikweek waar ons deur boodskappe, deur musiek, deur sang, deur die radio-uitsending soveel barte bereik bet, soveel mense aangeraak bet, soveel weer in aanraking gebring het met ' $n$ nuwe lewe wat ons vind in fesus Christus."

Hoe weet die prediker dit alles? Het hy insigte in die raadsplanne van God wat ander, gewone gelowiges nie het nie? Wil hy daardeur (bonatuurlike) legitimiteit aan sy bediening gee? Dikwels loop wat die Here wil en sê en doen naatloos oor in wat die prediker wil en sê en doen:

“... deur die Woord sê die Here vanmôre vir jou... Vanmôre sê ek vir u... dis waarom jy nou na my luister... Ek het vir u gesê dat God wil hê...” ens.

In werklikheid plaas die prediker sy preek in God se mond.

Waaraan moet ons hierdie outoritêre styl, wat plek-plek grens aan grootheidswaan, toeskryf? Dit sou 'n logiese uitvloeisel kon wees van die feit dat wettiese preke die gesag van die teks verlaat het. Daarom moet daar na substitute gesoek word, en die mees voor die hand liggende is: die prediker self! Hy of sy moet oorneem waar die teks, en God self, nie meer werksaam is nie. Daarom presenteer die prediker hom of haarself as een wat nie swak kán wees nie, nie swak dúrf wees nie, as een wat in sy of haar eie persoon aan al die eise van die Bybelteks voldoen het, wat voor die gemeente staan as die klinkklare voorbeeld van iemand wat kon doen waartoe die preek die gemeente oproep. Die ervaring van die prediker moet dan die hoorders motiveer om te reik na die onmoontlike, om hulle in te span om op 'n soortgelyke standaard te kom. Soms word die voorbeelde van voortreflike gelowiges met presies dieselfde oogmerk aan die gemeente voorgehou, naamlik sodat hulle kan wees of word soos ander mense was of is. Daar is egter niks so ondraaglik soos die eis wat van 'n voortreflike voorbeeld uitgaan nie! (Mark Twain).

In talle preke is die veronderstelde bron van gesag dus die prediker self. Ek volstaan met 'n laaste sin:

"The devil has certainly come to every service that I've ever preached. The sound goes wrong, people fall down, they sneeze and cough and do all kinds of things because the devil disturbs people." 
Hoe de duiwel weet die prediker dat die duiwel by elke preek wat hy preek teenwoordig is? Is dit nie 'n manier om die hoorders onder die indruk te bring van die gesag waarmee hy (altyd) praat nie? Iemand wat selfs die duiwel in beweging bring, móét tog gesag hê, of hoe?

\subsubsection{HERMENEUTIEK VAN DIE "EK"}

Dis merkwaardig hoe dik die stroom van die "ek" in baie preke loop. Soms bestaan die preek letterlik net uit 'n tweegesprek tussen die "ek" van die prediker en die gemeente, sonder dat dit ooit 'n tweegesprek tussen God en sy gemeente word. Baie kan inderdaad afgelei word uit die wyse waarop predikers die woordjies "ons", “ek", "jy”, "julle”, "hulle”, ens. gebruik, en veral die verbande wat daar tussen dié begrippe veronderstel of gelê word. Dit sou nie oordrewe wees om te sê dat die prediker dikwels in sy/haar persoon, met sy/haar insigte, ervaringe, geloof, ens. dié ontsluitingspunt van die preek word nie, dat alle verkondigingslyne in 'n hermeneutiek van die "ek" saamgebundel én ontknoop word.

'n Goeie voorbeeld hiervan is 'n preek waarin die tweede paragraaf só ingelui word:

"As ek vanaand vir u'n vraag sou vra en ek sou sê 'Wat is die uitstaande kenmerk van 'n Geesvervulde kind van die Here?', dan wil ek sê ons gaan vanaand baie antwoorde hoor."

Dit word gevolg deur 'n lang lys van antwoorde wat die prediker namens die gemeente gee, maar wat uiteindelik ook deur die prediker van die tafel gevee word, of ten minste gerelativeer word:

"Ek dink al hierdie antwoorde kan ons dalk in 'n sekere sin laat sien wat reg is... Maar weet u, Jesus Christus gee vir ons die duidelikste antwoord en die korrekte antwoord..."

Die prediker is die een wat die vrae vra, self die gemeente se antwoorde daarop verskaf, dit self as verkeerd verklaar, en self met die korrekte oplossing na vore kom - aangesien die gemeente nie deel het in sy insigte in die antwoorde van Christus nie. Die "hermeneutiese sirkel" word deur die "ek" van die prediker op gang én tot voltooing gebring. Dit sien 'n mens ook dwarsdeur die res van die preek, waar ons male sonder tal hoor:

"En ek wil... Ek wil u sê... Ek wil vir u sê u leef in gruwelike sonde. U sê: Hoe kry ek dit reg? Ek kry dit reg, want die Woord van die Here sê vir 
ons... Word vervul met die Heilige Gees...(sic) Ek weet daar's 'n bele verandering wat in u lewe moet plaasvind..." ens.

Dié prediker weet alles, wil alles, sê alles, doen alles wat nodig is om sy preek te laat "werk". In werklikheid, of ten minste grammatikaal gesproke, word daar in die hermeneutiek van die "ek" geen ruimte gelaat vir die werking van die genade nie, word die evangelie buite werking gestel. "Ek" neem die plek daarvan in.

\subsubsection{DIE VEREENSAMING VAN DIE PREDIKER}

Maar... geen mens kan, ten spyte van die front van outoriteit wat voorgehou word, met só 'n opgawe bly leef nie. Uiteindelik slaan dit op hom of haar terug, wreek die geweldige las om altyd te moet weet, om altyd sterk te moet wees, hom op diegene wat in die waan daarvan leef. Dit kan lei tot pessimisme en resignasie, tot preekmoegheid en homiletiese uitbranding wat by nie 'n geringe aantal predikers die geval is nie. Die oorheersende effek van hierdie valse outoriteit is ironies genoeg eensaamheid. Uit die aard van hulle beroep ís predikers soms eensame mense. Die bedoeling van die ekklesiale gesprek (hoofstuk 5.4) is onder meer juis dit: om die swygsaamheid van die gemeente, maar ook die eensaamheid van die prediker te deurbreek, deurdat dit die geweldige las om altyd die volle waarheid met volle sekerheid te verkondig van die skouers van die predikant afhaal en in die gemeente as gespreksgenote versprei. Wettisisme daarenteen, téér op die individualisme. Dit laat die gemeente as individue alleen met 'n Bybelteks wat hulleself wáár moet maak. Die eensaamste van almal is egter die geïsoleerde individu van die prediker. Hy of sy moet op die kansel verskyn as een wat reeds aan die eise van die Bybelteks voldoen het, reeds dit wat van die gemeente gevorder word, in sy of haar eie persoon voltrek het. Maar... wie is hiertoe in staat?

\subsection{4 'N GLIPS VAN DIE TONG?}

Een van die merkwaardigste ontdekkings van die analise van moralistiese preke is dat predikers (onbewustelik?) aanvoel dat alles in die preek nie evangelies pluis is nie. Keer op keer kom daar sinne voor wat vertolk sou kon word as pogings om dít wat verkeerd geloop het in die reine te bring, om as 't ware die probleem te formuleer waaraan hulle eie preek mank gaan - en te sê dat hulle juis dít nie wil doen nie!. Dit sou byna as 'n reël neergelê kon word: die oomblik wanneer 'n prediker elemente van die hermeneutiese onderbou van sy preek as 'n diskussiepunt na die oppervlak laat kom, en ter verdediging daarvan optree, dui hy of sy daarmee die 
dieperliggende problematiek van die preek aan. Ek het 'n lysie gemaak van enkele van hierdie uitsprake, wat in die betrokke gevalle inderdaad die werklike struktuur van die preek verraai:

"Hierin is geen sprake van sekere noodsaaklikbede of besondere voorwaardes wat u moet nakom nie."

"Dan moet ons ook dít leer: ons moet minder'n opinie óór die Woord van God uitspreek, en meer God se Woord self laat spreek.” (!)

'n Redelike blatante voorbeeld:

"As we look at this text I just pulled out three particular points that struck me when I read it, that seemed to be appropriate to us all today."

En, in 'n preek wat totaal en al by die Bybelteks verbypraat en eerder die teks - en Christus - misbruik as 'n handleiding van en voorbeeld vir tienerpsigologie:

"That is just a bit of totally irrelevant information that I thought you might like to bave."

\subsection{5 'N GEBROKE GESAG...}

Daar is reeds daarop gewys dat die gesag van die prediker en preek staan of val met die gesag van die Skrif (hoofstuk 4). Daarmee word nie 'n blote repetisie van die letter van die Skrif bedoel nie, maar 'n gesag wat in 'n sin "onmaakbaar" is, omdat dit geheel en al daarvan afhang of God deur die Bybelteks en die preek aan die woord kom (hoofstuk 3). Die prediker se gesag lê in sy of haar gesagsloosheid. Hulle is inderdaad "as one without authority" (vgl. die titel van Craddock se boek, 1979).

Die mag van predikers is 'n magtelose mag, hulle gesag 'n gebroke gesag. Iets hiervan sypel gewoonlik deur in die struktuur van die preek, raak die wyse waarop taal ingespan word in die verkondigingsproses. Bethel Müller skryf aangrypend: "Die prediking wil die ontmoeting tussen die lewende God en sy lewende gemeente dien deur die verkondiging van die lewende Woord. Hierdie ontmoeting kan 'n mens nie bewerk of skep nie, nie deur sy metodieke en deur sy redenaarsvermoë nie. Dit bly die vrug van die werking van die Heilige Gees. Maar die mens kan en moet in die prediking aan hierdie ontmoeting diensbaar wees. Hy moet dit doen deur deeglike eksegese, deur 'n worsteling om die regte interpretasie, deur 'n ywerige soeke na die openbaringsperspektiewe en deur 'n onvermoeide vertalingsdrang...maar veral ook deur self in die brandpunt van die ontmoeting te gaan staan. Alleen by wat werklik na die Woord 
geluister het, word daardeur geraak, gekwes, verwond... en alleen by wat deur die teks verwond is, is preekvaardig. Daarom bly die struktuur van die preek 'n gebroke en verslae struktuur, 'n deurkruiste struktuur... Op bierdie wyse bewaak die Skrif en die teks ook die struktuur en die taal van die prediking: dit kan alleen die stamelende taal en gebroke struktuur wees van een wat deur die teks self gegryp is...omdat by deur Christus fesus self gegryp is." (1973:135)

Wanneer Paulus die ABC van sy gesag as apostel, die grondbeginsel van sy bediening in 'n paar sinne, eintlik in 'n enkele woord moet uitspel, is dit die woordjie kruis (vgl.1 Kor. 2:2). Hierdie term is in die Pauliniese briewe 'n aanduiding van die totale aardse bediening van Jesus, sy totale lydensweg vanaf sy menswording in Bethlehem tot sy kruisdood op Golgota. Hierin word die grondpatroon vir die optrede en styl van die kerk en daarom ook die prediking neergelê, naamlik in die gesag van die kruis. 'n Gebroke styl veronderstel 'n prediker wat deur die teks deurkruis is, ja, deur die kruis in die teks geráák is. Hierin lê ons gesag. Maar wat 'n vreemde gesag is dit nie! Want die kruis is op die oog af die toonbeeld van magteloosheid, selfs ondergang. Maar, wat vir die wêreld die onsin van God is, is groter wysheid as die wysheid van mense, en wat vir die wêreld die swakheid van God is, is groter krag as die krag van mense. (1 Kor. 1:25)

Onsin. Volledige en volslae dwaasheid. Dís wat die prediking is.

Maar, wanneer 'n prediker genade ontvang om só vir 'n gemeente oor 'n teks te preek dat die teenwoordige Christus sigbaar word, geld daar ook ander beskrywings:

Krag, ver bo wat ons kan bid of dink (Efes. 3:20).

Wysheid, volledige en volslae wysheid!

Dís wat die prediking is. 


\section{Preekvoorbeeld 4}

\section{DÁÁR IS DIE LAM VAN GOD...! \\ (Johannes19-34)}

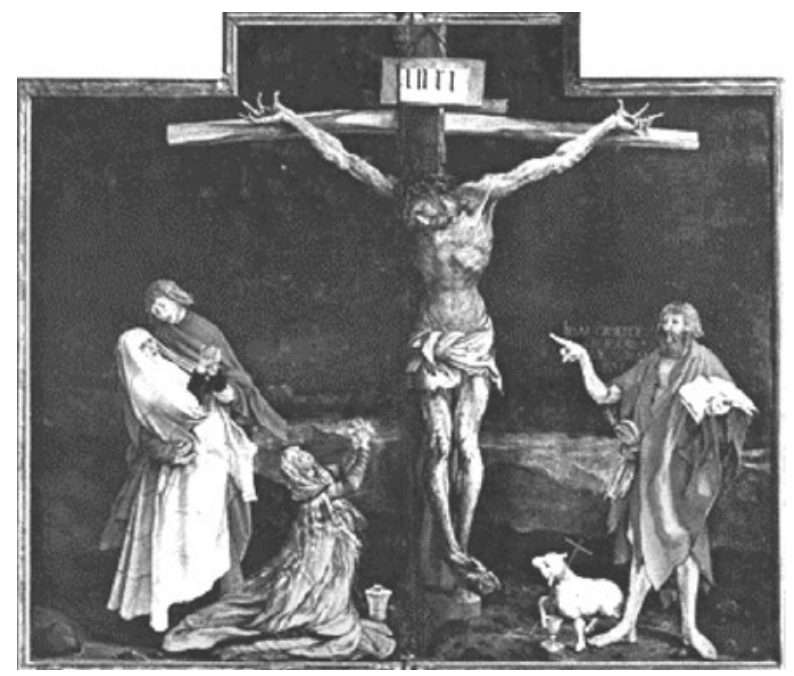

Die bekende skilder Matthias Grünewald het onder meer 'n aangrypende kruistoneel geskilder op die altaar in die kloosterhospitaal van Isenheim. Hande speel 'n belangrike rol op dié skildery. Daar is byvoorbeeld die uitgestrekte, biddende hande van Maria Magdalena en Maria, die moeder van Jesus; daar is die hande van Johannes, die Evangelis, wat vir Maria vashou; en dan is daar natuurlik die groteske, verwronge hande van die Gekruisigde, met spykers vasgekap aan die houtkruis. Johannes die Doper se hande is ook opvallend. Met die een hou hy 'n boek vas, waarskynlik 'n Bybelperkament, en met die ander wys hy na die Gekruisigde. Sy wysvinger is opvallend groot, eintlik groter as lewensgroot. Op 'n manier sit sy hele liggaam daaragter, daarbinne-in. Hierin lê die wese, die karakter, ja, die ganse identiteit van die Doper opgesluit: Om Christus uit te wys as die Lam van God wat die sonde van die wêreld wegneem...

Identiteit. Hoe baie word daar nie in ons tyd - ook in die kerk - hieroor nagedink nie! Wie ís die kerk, en watter rol moet die kerk byvoorbeeld in 'n land soos Suid-Afrika speel? Wat is ons roeping, en waar lê ons hoogste prioriteite? Wat is die rol van lidmate en gemeentes, van kerkrade en dominees? 
Ons is nie die eerste mense wat dié soort vrae stel nie. Dietrich Bonnhoefer vra byvoorbeeld uit die tronk: Is ek werklik dít, wat ander van my sê? Of is ek net dit, wat ek self van my weet? Hy het natuurlik ook verder gegaan, en gevra: Is ek uiteindelik dít wat Gód van my weet en sê? Ja, wie is ek ten diepste... voor Gód?

Ons teksverse bied hierop 'n aangrypende antwoord, skilder as't ware 'n prentjie voor ons oë af. Johannes die Doper is besig om in Israel te preek, om aan te kondig dat die dreigende toorn van God naby gekom het, dat die byl al klaar teen die wortel van die bome lê, en dat Een aan die kom is met sy skop in sy hand om sy dorsvloer deur en deur skoon te maak. Die koring sal Hy na die skuur toe bring, maar die kaf sal Hy met 'n onuitblusbare vuur verbrand (vgl. Matt. 3:1-12). As 'n soort brugfiguur staan hy daar, met die een voet nog in die wêreld van die Ou Testament, maar met die ander in die Nuwe.

Só indrukwekkend is hy dat daar 'n amptelike afvaardiging van die Sanhedrin in Jerusalem na hom toe gestuur word, om vas te stel wié hy nou eintlik is. Hulle omsingel hom as't ware met vrae:

"Wie is jy?"

"Ek is nie die Christus nie."

"Is jy Elia?" (Sommige het gemeen dat Elia sou herleef om 'n voorloper van die Messias te wees.)

"Nee, ek is nie."

"Is jy dan die Profeet?" (Ons weet nie wie presies bedoel word nie; in elk geval ook 'n Messiaanse voorloper.)

"Nee!"

Johannes die Doper tree as 't ware drie treë terug; stel Christus in die lig. Opvallend is veral sy eerste antwoord. In werklikheid antwoord hy nie die vraag wat hulle hom vra nie. Hulle vra hom: "Wie is jy?" Hy antwoord ontkennend: "Ek is nie die Christus nie." Hierdie antwoord is vir die kerk van groot belang. Dikwels oorskrei ons die grense, matig ons ons meer aan as wat ons mag. Dikwels maak ons asof die oordeel van Christus óns oordeel is, asof ons, die kerk, alle beheer oor sy koninkryk het. Asof óns die hoofrol in die Goddelike verlossingsdrama speel. Dikwels oorspeel ons ons hand: ons reken nog ons is besig om na Christus te wys, dan wys ons eerder 'n veroordelende vinger na die wêreld.

Luther was só sterk onder die indruk van hierdie neiging by ons dat hy sy preek oor hierdie verse juis só begin:

"Elkeen van ons wil van nature 'n Christus wees. Hierdie laster is so diep aangebore, dat geen menslike hart hom daarvan kan losmaak 
nie, omdat ons ganse natuur van hierdie versugting deurdronge en vergiftig is... Die menslike natuur verset hom daarteen om geheel en al ontbloot te word en alleen van Christus afhanklik te wees, om op niks anders te bou nie as op Christus, sonder enige verdienste of raad...Dit is die hoogste kuns, dat 'n mens Christus nie verloën nie, maar bely, omdat hierdie natuurlike plaag ons almal so aangebore is, dat elkeen Christus wil wees. Ja, ons ly nog almal daaronder, dat ons Christus wil wees, dit wil sê Iemand wat my kan help en verander... Daarom is hierdie evangelie geskrywe: dat almal wat ware Christene wil wees, so goed as moontlik hierdie kuns moet leer, dat hulle nié Christus is nie."

Ek is nié die Christus nie, verklaar Johannes die Doper sy identiteit. Miskien sou 'n mens dit soos volg kon parafaseer:

Ek is nie die Een na wie julle so hunker nie. Ek is nie die Verlosser nie, het nie die woorde van die ewige lewe nie, en ook nie die antwoorde op julle lewensvrae nie. Ek is nie die oplossing vir julle probleme nie, bied geen sin nie, en maak nie beel wat gebroke is nie. Ek kan julle nie van julle sonde bevry nie, nie julle skuld op my neem, en julle nie vryspreek nie. As julle dit alles by my soek, soek julle by die verkeerde adres. Die adres is dáár. Dáar is die Lam van God wat die sonde van die wêreld wegneem!

Dis 'n driedubbele ontkenning, 'n drievoudige nee. En tog is dit meer as net 'n drievoudige beklemtoning van die Doper se nederigheid, meer as net 'n ontkenning van wie hy nié is nie. Dis eerder 'n aanduiding van, 'n uitwysing van Wie ís. Maar, as 'n mens nou die rigting van sy wysvinger volg, staan jy stomgeslaan. Want daar staan Jesus, die Man van Nasaret, die Een wat histories gesproke uit Maria gebore is. Hy word genoem: Lam van God.

In hierdie titel word die geheim van die evangelie saamgevat. In Hom kom die inhoud van die koninkryk van God na ons toe. Hy ís self die koninkryk van God. Die bron en waarborg, die begin en einde daarvan. En hier staan hy voor ons! Die Een wat die oordeel van God openbaar, wat met die skop in die hand kom om die koring van die kaf te skei, wat die byl aanlê teen die wortel van die boom... is 'n Lam! Die Een in wie se hande die skop en die byl is, is die Een wie se hande gekrom, gespyker aan die kruis is!

Dáárin lê die hoop vir ons wêreld: die Een wat die sonde blootlê, is die Een wat dit wegneem; die Een wat oordeel, is die Een wat die oordeel op Homself neem! Ja, dáárin, in hierdie Lam, lê die hoop vir die mense op hierdie aarde, vir die mense van ons kontinent, van ons land, ons dorp, vir elkeen van ons.

Hierin lê ook die identiteit van die kerk: om dit, nee Hóm aan te toon, 
aan te dui, uit te wys, te verkondig, te roem. Dít is wat ons is: 'n mond wat vol hoop is, en 'n vinger wat vooruitwys... na Hóm. Gestaltes wat getuig van die genade, van Christus. Na Hóm word alle lyne getrek, en van hóm skiet alle strale uit. Hy is die inhoud van ons kerkwees, ons prediking, ja, ook ons teologie. Paulus stel dit trouens as die kern van sy bediening: ons verkondig nie onsself nie, maar Fesus Christus as die Here, en onsself as julle dienaars ter wille van fesus (2 Kor. 4:5). 'n Mens dink aan die eerste woorde van Spurgeon op die kansel van die Metropolitan Tabernacle in Londen waar hy vir baie jare die evangelie verkondig het:

"Ek is nie skaam om myself 'n Calvinis te noem nie; ek huiwer nie om die titel Baptis te dra nie, maar as jy vra wat is my belydenis, antwoord ek: Dit is Jesus Christus. Ek verbind my om Jesus Christus te verkondig, wat die krag en inhoud van die evangelie is, wat in Homself alle teologie is, die inkarnasie van elke kosbare waarheid.”

Of die belydenis van Martin Luther, wat hy telkens in sy lewe herhaal het: Niks anders as Christus verkondig nie!

Hierin lê die geheim van die identiteit van die kerk. Ons kán nie, mág nie, iets anders wees as wat ons ís nie. 'n Hand, 'n vinger, 'n getuienis...

Of ons nou vergaderings hou of in 'n erediens sit; 'n koppie tee inskink of 'n biduur bywoon, só klink dit: Dáár is die Lam van God wat die sonde van die wêreld wegneem! As ons uitreik na die wêreld, ons moue oprol en worstel met die probleme om ons, met die armoede, nood en lyding, moet ons moue oprol en hande uitsteek tegelykertyd 'n vingerwysing wees, en 'n uitroep: Dáár is die Lam van God wat die sonde van die wêreld wegneem! Hieraan moet al ons oordele en vooroordele, ons beplannings en strukture, ons ywer vir vernuwing en ons lojaliteit aan ons tradisies telkens gemeet word: Dáár is die Lam van God wat die sonde van die wêreld wegneem!

'n Hand, 'n vinger, 'n mond... gevul met die lewende stem van die evangelie.

(Uit: Het God 'n handvatsel? Bybelse getuienisse en gebede oor die onbegryplike wonder van God se genade en grootheid. CUM: Vereeniging. 2003) 


\section{Literatuur}

Aalders, W 1976. Herman Friedrich Koblbrïgge. Zijn leven, zijn prediking, zijn geschriften. Den Haag: JN Voorhoeve.

Adam, AKM 1995. What is postmodern Biblical criticism? Minneapolis: Fortress Press.

Anderson, WT (Ed) 1995. The truth about truth. De-confusing and re-constructing the postmodern world. New York: Tarcher/Putnam Books.

Arens, H; Dannowski, HH 1979. Predigten, die handeln belfen. Modelle für appelatives Reden. Gütersloher Verlagshaus Gerd Mohn.

Austin, JL 1972. Zur Theorie der Sprechakte. Stuttgart: Reclam.

Babin, P 1991. The new era in religious communication. Minneapolis: Fortress Press. Bailey, R 1991. Paul the preacher. Nashville: Broadman Press.

Barié, H 1977. Praktische Erfahrungen mit Rudolf Bohrens Predigtlehre. Ev Th 37 Jabrgang.

Barth, K 1924. Der Römerbrief 4 Aufl. München. Kaiser

Barth, K 1924. Not und Verheissung der Christlichen Verkündigung (Das Wort Gottes und die Theologie. Gesammelte Vorträge). München.

Barth, K 1924. Das Wort Gottes und die Theologie. Gesammelte Vorträge. München: Kaiser.

Barth, K 1935. Evangelium und Gesetz. Th Ex $b 32$.

Barth, K 1947. Kirchliche Dogmatik I/1. Zürich. Evangelischer Verlag Zollikon.

Barth, K 1957. Church dogmatics 2/2. Edinburgh: T \& T Clark.

Barth, K 1958. Church Dogmatics 4/2. Edinburgh: T and T Clark.

Barth, K 1960. Kirchliche Dogmatik IV/3. Zürich. Evangelischer Verlag Zollikon.

Barth, K 1964. Prayer and preaching. London: SCM Press LTD.

Barthes, R 1974. Die Lust am Text. Frankfurt. Suhrkamp Verlag.

Bastian, HD 1968. Vom Wort zu den Wörtern. Karl Barth und die Aufgaben der Praktischen Theologie. Ev Th 28 Jahrgang.

Bauman, Z 1993. Postmodern etbics. Cambridge, Mass.: Blackwell.

Bauman, Z 1995. Life in fragments. Oxford, Blackwell.

Bavinck, JH 1957. Exegese en Preek. Geref TT Jaargang 57.

Bellah, RN e.a. 1991. The good society. New York: Vintage Books.

Bennet, WJ 1993. The book of virtues. New York: Simon \& Schuster.

Berkhof, H 1975. Der Vorschuss des Geistes. Aktuelle Tendenzen in der Pneumatologie. Ev Kom 8 Jahrgang.

Berkouwer, GC 1949. Geloof en beiliging. Kampen: Kok.

Berkouwer, GC 1957. De mens het beeld Gods. Kampen. Kok.

Berkouwer, GC 1975. Studies in Dogmatics. Holy Scripture. Grand Rapids, Michigan: Eerdmans. 
Bluck, J 1989. Christian Communication Reconsidered. Geneva: WCC Publications. Bohren, R 1963. Predigt und Germeinde. Beiträge zur Praktischen Theologie. Stuttgart: Zwingli.

Bohren, R 1966. Die Gesetzlichkeit in der Predigt. (In Laienfrage und Predigt) Bern, 33-51.

Bohren, R 1971. Predigtlehre. München: Kaiser.

Bohren, R 1973. Fasten und Feiern. Meditationen über Kunst und Askese. Neukirchener Verlag.

Bohren, R 1975. Dass Gott schön werde. Praktische Theologie als theologische Ästhetik. München: Kaiser.

Bohren, R 1981. Vom Heiligen Geist. 5 Betrachtungen. München. Kaiser.

Bohren, R 1988. Das Ich in der Predigt. Konsequenzen für den Lektorendienst. In Das missionarische Wort 3/88, 98-107.

Bohren, R 1991. Predigen zum Weitersagen. Predigerausbildung in Kirche und Universität. Referat am 8.2.1991 bei der Generalversammlung des Okumenischen Vereins zur Förderung der Predigt e.V. Nr. 9/10.

Bohren, R 1993. Einheit und Zerissenheit der Kirche - Macht und Ohnmacht ihrer Predigt. Ev Th 53.

Bohren, R 1996. Praktische Theologie als Wissenschaftskritik. Anmerkungen zu Günter Grass: "Über das Sekundäre aus primärer Sicbt". (in Predigen aus Leidenschaft). Karlsruhe: Verlag Evangelischer Presseverband für Baden e. V.

Bohren, R; Jorns, KP, 1989. Die Predigtanalyse als Weg zur Predigt. Tubingen. Francke Verlag.

Bonhoeffer, D 1955. Ethics. London: SCM Press.

Bos, R 1992. Identificatie-mogelijkheden in preken uit het Oude Testament. Kampen: JH Kok.

Bos, R 1999. Literatuur bij de preekvoorbereiding (uit: Postille 1999-2000) Zoetermeer: Uitgeverij Boekencentrum.

Brecht, M 1986. Martin Luther. Ordnung und Abgrenzung der Reformation 15211532. Stuttgart.

Brillenburg-Wurth, G 1934. De Christelijke vrijheid. Kampen: JH Kok.

Brooks, P 1964. On Preaching. New York: Seabury.

Brown, RM 1984. Unexpected News. Reading the Bible with Third World eyes. Philadelphia: Westminster Press.

Brueggemann, W 1978. Prophetic imagination. Philadelphia: Fortress Press.

Brueggemann, W 1988. The social nature of a Biblical text for preaching. (In: Preaching as a social act. Theology and practice. Van Seters Ed) Nashville: Parthenon Press.

Brueggemann, W 1989. Finally comes the poet. Daring speech for proclamation. Minneapolis: Fortress Press.

Brueggemann, W 1993. Texts under negotiation. The Bible and postmodern imagination. Minneapolis: Fortress Press. 
Brueggemann, W 1993. The Bible and Postmodern Imagination - texts under negotiation. London: SCM Press.

Brueggemann, W 1995. Preaching as re-imagination. Theology Today 52, 313-329. Brueggemann, W 1997. Cadences of Home. Preaching among Exiles. Louisville: John Knox Press.

Buechner, F 1977. Telling the Truth. The Gospel as Tragedy, Comedy and Fairy Tale. San Francisco: Harper and Row.

Bugg, CB 1992. Preaching from the inside out. Nashville, Tennessee: Broadman.

Burger, CW 1983. Die verhouding wet-evangelie as hermeneuties-homiletiese prinsipe by Hans-foachim Iwand. Ongepubliseerde D. Th.-proefskrif. Universiteit van Stellenbosch.

Burger, CW 1996 e.a. Riglyne vir prediking oor die Christelike deugde. Woord teen die lig 3/4 Kaapstad: Lux-Verbi.

Buttrick, D 1987. Homiletic: Moves and structures. Philadelphia: Fortress Press.

Campbell, C 1997. Preaching Jesus. New Directions for Homiletics in Hans Frei's Postliberal Theology. Grand Rapids: Eerdmans.

Capps, D 1987. Deadly sins and saving virtues. Philadelphia: Fortress.

Cilliers, J 1992. Prediking as ekklesiale diskoers: 'n ontwerp. NGTT 33/3. 383390.

Cilliers, J 1994. God vir ons. 'n Analise en beoordeling van Nederduitse Gereformeerde volksprediking (1960-1980). Kaapstad: Lux Verbi.

Cilliers, J 1994. Pneumatologie en metodologie: 'n homiletiese perspektief. NGTT 35/2. 251-255

Cilliers, J 1994. Prediking as resepsie-estetika: 'n verkenning. NGTT 35/4. 583-588

Cilliers, J 1995. Om God te sien... selfs in die kleinste besonderbeid van jou lewe. Vereeniging: Christelike Uitgewersmaatskappy.

Cilliers, J 1996. Die uitwissing van God op die kansel. Onstellende bevindinge oor SuidAfrikaanse prediking. Kaapstad: Lux Verbi.

Cilliers, J 1997. Sal die regte Jesus opstaan, asseblief? 52 Bybelse getuienisse oor die uniekheid van Christus. Vereeniging: Christelike Uitgewersmaatskappy.

Cilliers, J 1998. Die uitwysing van God op die kansel. Inspirerende perspektiewe op die prediking - om God te sien en ander te láát sien. Kaapstad: Lux Verbi.

Cilliers, J 1998. Korrels van die Koninkryk. Grepe uit die gelykenisse van Jesus. Pretoria: JL van Schaik.

Cilliers, J 1998. Veilig onder God se vlerk. Woorde van verwondering en vertroosting uit die Psalms. Vereeniging: Christelike Uitgewersmaatskappy.

Cilliers, J 2000. Die genade van gehoorsaambeid. Hoe evangelies is die etiese preke wat ons in Suid-Afrika hoor? Kaapstad: Lux Verbi BM.

Cilliers, JH 1979. Veni Creator Spiritus. 'n Homileties-sistematiese besinning oor die belang van die Reformatore, Karl Barth, Rudolf Bultmann en Rudolf Bohren vir die pneumatologies-begronde preekleer. Ongepubliseerde M-Skripsie, Universiteit van Stellenbosch. 
Cilliers, JH 1982. Soos woorde van God. Ontwerp van 'n preekanalitiese model. Ongepubliseerde D. Th.-proefskrif. Universiteit van Stellenbosch.

Cilliers, JH 1990. Meer as mossies. Oordenkings en Bybelstudie oor die Onse Vadergebed (Matt. 6:9-13). Kaapstad: Lux Verbi.

Cilliers, JH 1991. Voorskrif vir vrybeid. Oordenkings en Bybelstudie oor die tien gebooie. Kaapstad: Lux Verbi.

Cilliers, JH 1996. Daar is 'n God vir gebrokenes. Vereeniging: CUM.

Cilliers, JH 1999. In die greep van God. Sewe ankers van sekerbeid vir die derde millennium. Vereeniging: CUM.

Cox, H 1969. The feast of fools. A theological essay on festivity and fantasy. London: Harper and Row.

Craddock, FB 1971. As One without Authority. Nashville: Abingdon Press.

Craddock, FB 1978. Overhearing the gospel. Nashville: Abingdon Press.

Craddock, FB 1985. Preaching. Nashville: Abingdon Press.

Cranfield, CEB 1974. The freedom of the Christian according to Romans 8:2. New Testament Christianity for Africa and the world (Essays for H Sawyer). SPCK, 91-98.

Croatto, JS 1987. Biblical Hermeneutics: Toward a theory of reading as the production of meaning. Maryknoll, New York: Orbis Books.

Crossin, JW 1985. What are they saying about virtue? New York: Paulist Press.

Cussons, S 1997. 'n Engel deur my kop. 'n Keuse uit haar religieuse gedigte deur die digter en Amanda Botha. Kaapstad: Tafelberg.

Daiber, KF e.a. 1983. Predigen und Hören. Ergebnisse einer Gottesdienstbefragung 2. Kommunikation zwischen Predigern und Hörern. Sozialwissenschaftliche Untersuchungen. München: Kaiser.

De Bono, E 1990. Lateral Thinking. Penguin.

De Graaf, J 1971. De Ethiek van het Immoralisme. Nijkerk.

De Jong, OJ 1972. Nederlandse Kerkgeschiedenis. Callenbach: Nijkerk.

De Quervain, A 1930. Gesetz und Freibeit. Stuttgart.

De Ru, G 1967. Over vrijheid. Wageningen. H Veenman en Zonen.

Deist, F 1988. 'Gekontroleerde' eksegese en/of 'kreatiewe' uitleg. HTS 44/1, 39-54.

Den Boer, C 1974. Functie van de Wet in de Prediking. Th Ref, 251-261.

Den Dulk, M 1999. Leren preken met Augustinus. (uit: Postille 1999-2000) Zoetermeer: Uitgeverij Boekencentrum.

Dijk, K 1952. Het Gericht Gods in de Prediking des Woords. Van Keulen: Delft.

Dingemanns, GDJ 1991. Als hoorder onder de hoorders... Een hermeneutische bomiletiek. Kampen: JH Kok.

Dingemans, GDJ 1996. Preken in een postmoderne konteks. In: Prediking. Kommunikasie in konteks. Voortrekkerhoogte: Makro Boeke.

Dostojevski, F 1959. Die Brüder Karamasoff. München: Piper

Douma, J 1973. Voorbeeld of gebod? Amsterdam.

Du Preez, JJ 1991. Neurokognitiewe integrasie in die leerproses. Per Linguam 7/1, 25-37. 
Dulles, A 1988. Models of the church. A critical assessment of the church in all its aspects. Dublin: Gill and Macmillan.

Eagleton, T 1996. The illusions of postmodernism. Oxford: Blackwell Publishers Ltd. Enquist, RJ 1980. The living God: A study in the contemporary discussion on law and gospel in Lutheranism. Michigan.

Everett, W 1988. God's federal republic. New York: Paulist Press.

Farris, S 1998. Preaching that Matters. The Bible and Our lives. Louisville: Wesminster/John Knox.

Ford, DS 1990. Sins of omission. Minneapolis, Minn.: Fortress Press.

Forde, GO 1969. The Law-Gospel Debate. Minneapolis.

Fowl, SE/Jones, LY 1991. Reading in communion. Scripture and Ethics in Christian life. London: SPCK.

Fuller, DP 1980. Gospel and Law: Contrast or Continuum. Grand Rapids.

Gadamer, H G 1960. Wabrheit und Methode. Tübingen.

Geyer, HG 1978. Wahre Kirche? Betrachtungen über die Möglichkeit der Wahrheit einer christlichen Kirche. Ev. Th. 38 Jahrgang.

Gollwitzer, H 1956. Zur Einheit von Gesetz und Evangelium. (In Antwort. Festschrift für Karl Barth.) Zollikon-Zürich, 287-309.

Graves, M 1997. The Sermon as Symphony. Preaching the literary forms of the New Testament. Pasadena: Judson.

Green, G 1989. Imagining God. Theology and the Religious Imagination. New York: Harper and Row.

Greidanus, S 1970. Sola Scriptura. Problems and principles in preaching historical texts. Toronto, Canada: Wedge Publishing Foundation.

Halver, O 1970. Hoppereiter mit dem lieben Gott. Stuttgart: Radius.

Harbsmeier, G 1972. Pneumatische Homiletik. Zur Predigtlehre von Rudolf Bohren. Ev Th 32 Jahrgang.

Hasselmann, N 1977. Predigthilfen und Predigtvorbereitung. Gütersloher Gerd Mohn. Hauerwas, S 1981. A community of character. Notre Dame: University of Notre Dame Press.

Hauerwas, S 1983. The peaceable kingdom. Notre Dame: University of Notre Dame Press.

Hauerwas, S 1985. The gesture of a truthful story. Th. Today 42/1985: 181-189.

Hesse, HK 1935. Herman Friedrich Koblbrügge. Wuppertal-Barmen: Emil Müllers Verlag.

Hilkert, M C 1998. Naming Grace. Preaching and the sacramental Imagination. New York: Continuum.

Hillman, J 1979. Insearch. Irving, Texas: Spring.

Hoffmann, M 1995. Ethik predigen: Probleme, Modelle, Beispiele. Waltrop: Spenner. Holmgren, FC 1997. The Old Testament and the Significance of Jesus. Maintaining Christian Identity. Grand Rapids/Michigan: Eerdmans.

Iser, W 1976. Der Akt des Lesens. Theorie ästhetischer Wirkung. München: UTB. 
Iwand, H J 1964. Gesetz und Evangelium. Nachgelassene Werke 4. München: Kaiser. Jabusch, WF 1981. The person in the pulpit. Preaching as caring. Nashville: Abingdon Press.

Janse van Rensburg, J 1991. 'n Kritiese ontleding van moralisme in die prediking. Ongepubliseerde D. Th. Proefskrif. Universiteit van die Oranje-Vrystaat.

Janse van Rensburg, J 2000. The paradigm shift. An introduction to postmodern thought and its implications for theology. Pretoria: Van Schaik.

Jonker, E 1998. Van verstaan naar vertolken. Een praktisch-theologische analyse van de voorbereiding van een preek of catechese over de Openbaring van Fohannes. Groningen: Self uitgegee.

Jonker, WD 1976. Die Woord as opdrag. Pretoria: NG Kerk-Boekhandel.

Josuttis, M 1966. Gesetzlichkeit in der Predigt der Gegenwart. München: Gütersloh. Josuttis, M 1970. Über den Predigteinfall. EvTh 30, 627-640

Josuttis, M 1973. Das Wort und die Wörter: zur Kritik am Predigtverständnis Karl Barths (in Freispruch und Freiheit: theologische Aufsätze für Walter Kreck.) München: Kaiser.

Josuttis, M 1980. Praxis des Evangeliums zwischen Politik und Religion. München: Kaiser.

Josuttis, M 1995. Gesetz und Evangelium in der Predigtarbeit. Homiletische Studien 2. Chr. Kaiser Gütersloher Verlagshaus.

Kamphaus, F; Zerfass, R 1977. Ethische Predigt und Alltagsverhalten. KaiserGrünewald.

Kearny, R 1988. The wake of imagination. Ideas of creativity in Western Culture. London: Hutchinson.

Kerlen, W 1976. Gesprach uber die Predigt. Die Einrichtung der Predigtkritik in der Gemeinde. Das Miss: Wort.

Klijn, AFG 1974. Gebod en zedelijk handelen volgens het Nieuwe Testament. Rondom het Woord 16, 109-120.

Konrad, J 1973. Sozialethische Themen auf der Kanzel: grundlegende Erwagungen, kommentierte Modelle, eigene Entwurfe. Hamburg: Agentur des Rauhen Hauses.

Kreck, W 1975. Grundfragen christlicher Ethik. München: Kaiser.

Kress, GR \Hodge, R 1979. Language as Ideology. London: Routledge and Kegan Paul.

Labuschagne, CG 1974. Gebod en zedelijk handelen. Rondom het Woord 16, 95 108.

Landau, E 1969. Psychologie der Kreativität. München: Basel.

Landau, R 1981. "Komm, Heiliger Geist, du Tröster wert ...” Gestaltungen des Heiligen Geistes. Ev Th 41 Jahrgang.

Lange, E 1976. Predigen als Beruf. Stuttgart: Kreuz Verlag.

Langer, SK 1980. Philosophy in a new key. A study in the symbolism of reason, rite and art. Cambridge: Harvard University Press.

Lewis, CS 1955. Mere Christianity. Glasgow: Collins. 
Linn, R 1996. A teacher's introduction to postmodernism. Illinois: National Council of Teachers of English.

Lloyd-Jones, DM 1976. Preaching and preachers. London: Hodder and Stoughton Long, EL 1982. A survey of recent Christian etbics. New York: OUP.

Long, TG 1990. The use of Scripture in Contemporary Preaching. In Interpretation 44, 341-352.

Long, TG 1989. The witness of preaching. Louisville, Kentucky: Westminster/John Knox.

Long, TG 1996. Preaching and the literary forms of the Bible. Philadelphia: Fortress.

Louw, D 2001. Creative hope and imagination in a Practical Theology of aesthetic (artistic) reason. 4th International Academy of Practical Theology. Quebec International Conference, Canada, 14-20 May 1999. In: Paul Ballard \& Pam Couture (eds.), Creativity, imagination and criticism: the expressive dimension in Practical Theology. Cardiff: Cardiff Academic Press, 91-104.

Lowry, EL 1980. The homiletical plot: The sermon as narrative art form. Atlanta: John Knox.

Lowry, EL 1985. Doing time in the pulpit. The relationship between narrative and preaching. Nashville: Abingdon Press.

Lowry, EL 1995. Narrative preaching. In Willimon, W and Lischer, L (eds) Concise encyclopedia of preaching: 341-344. Louisville: John Knox Press.

Lukken, G. 1990. Liturgie en Zintuiglijkheid. Over de betekenis van lichamelijkheid in de liturgie. Hilversum: Gooi en Sticht.

Lüthi, W 1950. Die Zehn Gebote Gottes. Basel: Friedrich Reinhardt Verlag.

MacIntyre, A 1984. After virtue. Notre Dame: University of Notre Dame Press (second edition).

Martin, GM 1977. Theologische Asthetik und Praktische Theologie. Ev Th 37 fabrgang.

Martindale, C 1981. Cognition and Consciousness. Homewood-Illinois: Dorsey Press.

McClure, J 1991. Narrative and Preaching: Sorting it all out. Fournal for Preachers 15: 24-29.

McClure, J 1995. The roundtable pulpit. Where leadership and preaching meet. Nashville: Abingdon Press.

McAfee Brown, R. 1984. Unexpected News. Reading the Bible with Third World Eyes. Philadelphia: Westminster.

McClendon, JW 1986. Systematic theology: ethics. Nashville: Abingdon Press.

McLaughlin, RW 1979. The ethics of persuasive preaching. Grand Rapids, Michigan: Baker Book House.

Meeks, W 1983. The first urban Christians. New Haven: Yale University Press. Meeks, W 1993. The origins of Christian morality. New Haven: Yale University Press. Meilaender, GC 1984. The theory and practice of virtue. Notre Dame: University of Notre Dame Press. 
Merton, T 1977. Raids on the unspeakable. London: Burns and Oates.

Meuser FW (Ed)1969. Interpreting Luther's Legacy. Minneapolis: Augsburg.

Meuser FW 1983. Luther the preacher. Minneapolis: Augsburg.

Mieth, D 1984. Die neue Tugenden: Ein ethischer Entwurf. Düsseldorf: PatmosVerlag.

Milk, O s.j. Martin Luther. Sy lewe en werk. Genadendal: Genadendalse drukkery.

Miskotte, KH 1941. Het Waagstuk der Prediking. Den Haag: DA Daamen's.

Miskotte, KH 1971. Om de waarheid te zeggen. Kampen: JH Kok.

Miskotte, KH 1976. ... als een die dient. Volledige uitgave van het 'Gemeenteblaadje Cortgene'. Baarn: Ten Have.

Möller, C 1996. Der Hörer als zweiter Prediger. Zur Bedeutung der Rezeptionsästhetik für die Homiletik (in Predigen aus Leidenschaft). Karlsruhe: Verlag Evangelischer Presseverband für Baden e. V.

Moltmann, J 1971. Theology and joy. London: SCM Press Ltd.

Moltmann, J 1974. Freedom in the light of hope. 7 Th SA 6.

Moltmann, J 1975. Kirche in der Kraft des Geistes. Ein Beitrag zur Messianischen Ekklesiologie. Munchen: Chr. Kaiser Verlag.

Moulle, CFD 1981. The Christian understanding of law and grace. ChristianFewish Relations 14, 52-61.

Mouw, RJ 1992. Uncommon decency: Christian civility in an Uncivil World. Downers Grove, Illinois: Intervarsity Press.

Moyaert, P (Ed) 1981. Jacques Lacan: Begeerte - taal - subjectiviteit. In Denken in Parijs. Alphen aan den Rijn: Samson Uitgeverij.

Müller, BA 1961. Die lewende Woord aan die mens van die hede. 'n Bespreking van die vrae rondom die aktuele Woordverkondiging. Zaandijk: J Heijnis Tsz.

Müller, BA 1973. Die eksegetiese onderbou van die struktuur van die prediking, in PA Verhoef (red.). Sol Iustitiae. Kaapstad: NG Kerk-Uitgewers, 121-138.

Müller, BA 1987. Tendense in Afrikaanse Godsdiens Programme. Stellenbosch: RGN Navorsingsprojek.

Müller, BA 2002. Liturgical and homiletical revisioning to generate hope for a just society. In Divine Fustice - Human Fustice. Ed. Dreyer, JS; Van der Ven, JA. Pretoria: Unisa Press.

Müller-Schwefe, HR 1973. Die Praxis der Verkündigung. Möglichkeiten geistlicher Rede in unserer Zeit. Hamburg: Im Furche-Verlag.

Naumann, M 1975. Gesellschaft Literatur Lesen. Literaturrezeption in theoretischer Sicht. Berlin: Aufbau Verlag.

$\mathrm{Nel}, \mathrm{M}$ 2001. Ek is die verskil. Die invloed van persoonlikbeid in die prediking. Bloemfontein: CLF-Uitgewers.

Nembach, U 1972. Predigt des Evangeliums. Neukirchen-Vluyn.

Neuhaus, RJ (ed) 1986. Virtue - public and private (Encounter Series) Grand Rapids: Eerdmans.

Niebergall, A 1971. Aufgabe der Predigt (ed. Gert Hummel), 295-320. 
Niebuhr, HR 1941. The meaning of revelation. New York: Collier Books.

Noordmans, O 1937. Zoeklichten. Zeist.

Nürnberger, K 1981. The Law-Gospel debate as a possible basis for a theological ethic. Th Ev 14, 25-47.

Odendaal, DH 1978. Prediking van die Wetsgedeeltes in die Ou Testament. NGTT 19, 163-183.

Osborne, GR 1999. Christianity challenges postmodernism. In: The relationship between epistemology, hermeneutics, Biblical theology and contextualization. Understanding truth. (Ed. Kennard, DW). Lewiston: The Edwin Mellen Press.

Paivio, A; Foth, D 1971. Imaginal and verbal mediation and noun concreteness in paired-associate learning: The illusive interaction. Fournal of verbal learning and verbal behavior, 9, 384-390.

Patte, D 1984. Preaching Paul. Philadelphia: Fortress Press.

Percy, W 1979. The Message in a Bottle. New York.

Peters, A 1981. Gesetz und Evangelium. Gütersloh.

Peterson, EH 1992. Under the Unpredictable Plant. An Exploration in Vocational Holiness. Grand Rapids, Michigan: Eerdmans.

Peterson, EH 1995. Working the angles. The shape of pastoral integrity. Michigan: Eerdmans.

Picht, G 1980. Hier und fetzt. Philosophieren nach Auschwitz und Hiroschima. Stuttgart: Klett-Cota.

Pieper, J 1966. The four cardinal virtues. Notre Dame: University of Notre Dame Press. Pieterse, HJC 1991. Gemeente en Prediking. Kaapstad: NGKB.

Pilch, JJ; Malina BJ 1993. Biblical social values and their meaning: a handbook. Peabody, Mass.: Hendrickson.

Porter, J 1990. The recovery of virtue: The relevance of Aquinas for Christian Ethics. Louisville, Kentucky: Westminster/John Knox Press

Raible, W 1989. Christliches Ethos und gottesdienstliche Verkundigung: Uberlegungen zum Selbstverstandnis ethischer Predigt. Frankfurt am Main: Lang.

Rasmussen, L 1993. Moral fragments and moral community. Minneapolis: Fortress Press.

Ridderbos, HN. Vrijheid en wet in Galate. Arcana Revelata.

Ridderbos, J 1922. Het Oude Testament in onze prediking. Kampen: JH Kok.

Riegert, ER 1990. Imaginative Shock. Preaching and Metaphor. Burlington: Trinity Press.

Rose, L 1997. Sharing the Word: Preaching in the roundtable church. Louisville, KY: Westminster/John Knox.

Ross-Bryant, L 1981. Imagination and the life of the Spirit: an introduction to the study of religion and literature. Chico: Scolars Press.

Runia, K 1981. Heeft preken nog zin? Kampen: JH Kok.

Saliers, D 1994. Worship as Theology. Foretaste of glory divine. Nashville: Abingdon. Schrage, W 1988. The ethics of the New Testament. Philadelphia: Fortress Press. 
Schreiter, RJ 1986. Constructing local theologies. New York: Orbis.

Seitz, CR 1998. Word without End. The Old Testament as Abiding Theological Witness. Grand Rapids/Michigan: Eerdmans.

Sider, R; Brubaker, DJ (Eds) 1982. Preaching on peace. Philadelphia: Fortress Press. Sillevis-Smit, JH. s.j. Onse Vader wat in die hemele is. Johannesburg: Boekhandel De Jong (Edms.) Bpk.

Smedes, LB 1983. Mere morality. Grand Rapids, Michigan: Eerdmans.

Smedes, LB 1990. A pretty good person. San Francisco: Harper \& Row.

Smelik, EL 1967. De Ethiek in de verkondiging. Nijkerk: Callenbach.

Smit, DJ 1987. Hoe verstaan ons wat ons lees? 'n Dink - en werkboek oor die bermeneutiek vir predikers en studente. Kaapstad: NG Kerk-Uitgewers.

Soskice, JM 1985. Metaphor and religious language. Oxford: Clarendon Press.

Stock, A 1974. Umgang mit theologischen Texten. Methoden Analysen Vorschläge. Köln: Benziger Verlag.

Stott, JRW 1982. I believe in Preaching, London: Hodder and Stoughton.

Stout, J 1988. Ethics after Babel. Boston: Beacon Press.

Strauss, DFM 1972. Wet en Evangelie. NGTT 13\3, 177-193.

Stuempfle, HG 1978. Preaching Law and Gospel. Philadelphia.

Suggit, J 1974. Freedom to be: Peter Abelard's doctrine of the atonement.

7 Tb $S A 8$.

Theron, PF 1996. Liberating humour. Calvinism and the comic vision. In Studies in Reformed Theology Volume 1, 208-224.

Thielicke, H 1965. Leiden an der Kirche. Ein persönliches Wort. Hamburg: FurcheVerlag.

Thomas, D 1979. The face of Christ. London: Hamlyn.

Tisdale, L T 1997. Preaching as Local Theology and Folk Art. Minneapolis: Fortress. Troeger, T 1982. Creating fresh images for preaching. Valley Forge: Judson.

Troeger, T 1987. Homiletics as imaginative theology. Homiletic XII/ 2, 27-38.

Troeger, T 1990. Imagining a sermon. Nashville: Abingdon Press.

Troeger, TH 1999. The landscapes of the heart. How our imagined worlds shape the preaching of the gospel. In Preaching as God's Mission. Studia Homiletica 2. Tokyo: Kyo Bun Kwam, 85-95.

Vaessen, JC 1997. Tussen Schrift en preek. Ontwerp van een analysemodel voor de bijbelinterpretatie in preken met gebruikmaking van de tekstuele hermeneutiek van Paul Ricoeur. Kampen: JH Kok.

Van den Berg, J. De wetsprediking in historisch perspectief. De Thora in de Thora 1. De Graafschap. Aalten, 30-49.

Van der Geest, H 1981. Presence in the pulpit: The impact of personality in preaching. Atlanta: John Knox.

Van der Velden, MJG 1989. Stimme und Schrift (in Die Predigtanalyse als Weg zur Predigt) Tübingen: Francke Verlag.

Van der Walt, PJ; Du Toit, C 1999: Vrae oor die "revised common lectionary" as 
hulpmiddel vir die bediening van die Woord in gemeentes. PTSA 14/2: 112119.

Van Hoof, P 1974. Intermezzo. Kontinu<teit en diskontinu<teit in de theologie van AA van Ruler. Amsterdam: Ton Bolland.

Van Melle, J 1968. Bart Nel. Pretoria: JL van Schaik Bpk.

Van Niftrik, GC 1946. Kleine Dogmatiek. Nijkerk.

Van Oort, J 1989. Augustinus. Facetten van leven en werk. Kampen: JH Kok.

Van Oort, J 1991. Bediening van het heil. Augustinus over de prediking. Leiden: Uitgeverij JJ Groen en Zoon.

Van Ruler, AA 1970. Waarom zou ik naar de kerk gaan? Nijkerk: Callenbach

Van Ruler, AA 1974. De vervulling van de wet. Een dogmatische studie over de verbouding van openbaring en existentie. Nijkerk: Callenbach.

Van Ruler, AA. 1969. Theologisch Werk. Deel 1. Nijkerk: Callenbach.

Van Seters, A (Ed) 1988. Preaching as a social act. Theology and practice. Nashville: Parthenon Press.

Velema, WH 1959. Wet en evangelie. Assen.

Velema, WH 1979. De liefde is de vervulling van de Wet. (In Uw Knecht hoort, red J Kruis). Amsterdam.

Velema, WH 1989. Ethische vragen in prediking en pastoraat. Kampen: Kok.

Verhey, A 1984. The great reversal. Grand Rapids, Michigan: Eerdmans.

Villa-Vicensio, C; de Gruchy, J (eds.) 1994. Doing ethics in Context: South African Perspectives. Maryknoll, New York: Orbis Books; Cape Town: David Philip.

Vos, CJA 1996. Homiletiese flitse in die hermeneutiese spieël van Paul Ricoeur, 1 en 2. PTSA 11/1: 58-78.

Vosloo, RR 1995. Etiek en die deugde: 'n kritiese ondersoek na aanleiding van die herwaardering van die deugde in morele besinning. NGTT 36/2, Junie 1995, pp 272282.

Wallace, JA 1995. Imaginal preaching. An archetypal perspective. New York: Paulist Press.

Ward, RF 1992. Speaking from the heart. Preaching with passion. Nashville: Abingdon Press.

Wardlaw, DM 1983. Preaching Biblically. Philadelphia: The Westminster Press.

Webb, J M 1998. Preaching and the challenge of Pluralism. St Louis: Chalice.

Welsch, W 1988. Unsere postmoderne Moderne. Weinheim: VCH Verlagsgesellschaft mbH.

Wepener, CJ; Müller, BA 2001. Liturgiese kitsch? - 'n Liturgiewetenskaplike verkenning van 'n Gereformeerde ritueel. NGTT 42/3 en 4, 480-493.

Willson, PS; Gaventa BR 1998. Preaching as the Re-reading of Scripture. In Interpretation 52 (4), 392-404.

Wilson, PS 1988. Imagination of the heart: New understandings in preaching. Nashville: Abingdon Press.

Wilson, PS 1995. The practice of preaching. Nashville: Abingdon Press. 
Wolf, AGB 1968. Vensters in de preek: een pleidooi voor het gebruik van illustraties in de prediking. Franeker: Wever.

Yancey, P 1997. What's so amazing about grace? Grand Rapids, Michigan: Zondervan. 
Prediking - hier in Johan Cilliers se vernuwende jongste boek beskryf as die hart en siel van die kerk - vra om sowel konstante hersiening as om trou aan die beginsels. Vandaar die boek se subtitel: "Nuut gedink oor die basiese beginsels".

En soos die titel aandui, neem die boek indringend en verbeeldingryk tot tema die Lewende in die homiletiese dinamika: die lewende stem van God, van die Woord, van die gemeente en uiteindelik van die prediker.

Cilliers doen vanuit verskillende teoretiese en praktiese gesigspunte 'n kritiese ondersoek na die toestand en toekoms van die prediking, en hy pak met oortuiging omstrede kwessies soos die geldigheid van wettiese en moralistiese prediking aan. Hy ontwikkel 'n kommunikatiewe model wat hy op verrassende wyse aan die hand van kunswerke verduidelik. Vier voorbeeldpreke demonstreer sy benadering tot die saak.

Die lewende stem van die evangelie is 'n gesaghebbende teksboek vir alle studente van die teologie en 'n aansporende handleiding vir predikers.

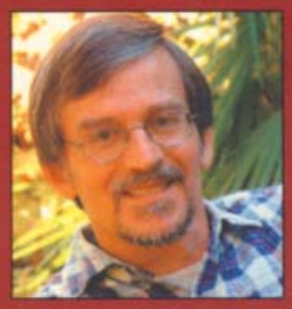

Johan Cilliers is die skrywer van verskeie boeke en talle artikels oor die Homiletiek. Hy is senior lektor in die Departement Praktiese Teologie en Missiologie aan die Universiteit Stellenbosch se Teologiese Kweekskool.

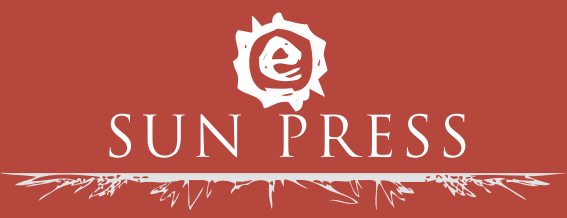

